\title{
UNIAXIAL TENSILE PROPERTIES OF ZIRCALOY CONTAINING OXYGEN: SUMMARY REPORT
}

\author{
by \\ A. M. Garde, H. M. Chung, \\ and T. F. Kassner
}

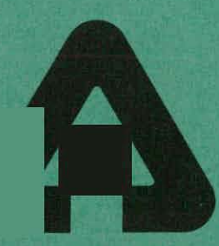

IONNE NATIONAL LABORATORY, ARGONNE, ILLINOIS

Prepared for the U. S. NUCLEAR REGULATORY COMMISSION under Contract W-31-109-Eng-38 


\section{DISCLAIMER}

This report was prepared as an account of work sponsored by an agency of the United States Government. Neither the United States Government nor any agency Thereof, nor any of their employees, makes any warranty, express or implied, or assumes any legal liability or responsibility for the accuracy, completeness, or usefulness of any information, apparatus, product, or process disclosed, or represents that its use would not infringe privately owned rights. Reference herein to any specific commercial product, process, or service by trade name, trademark, manufacturer, or otherwise does not necessarily constitute or imply its endorsement, recommendation, or favoring by the United States Government or any agency thereof. The views and opinions of authors expressed herein do not necessarily state or reflect those of the United States Government or any agency thereof. 


\section{DISCLAIMER}

Portions of this document may be illegible in electronic image products. Images are produced from the best available original document. 
The facilities of Argonne National Laboratory are owned by the United States Government. Under the terms of a contract (W-31-109-Eng-38) between the U. S. Energy Research and Development Administration, Argonne Universities Association and The University of Chicago, the University employs the staff and operates the Laboratory in accordance with policies and programs formulated, approved and reviewed by the Association:

\section{MEMBERS OF ARGONNE UNIVERSITIES ASSOCIATION}

The University of Arizona Carnegie-Mellon University

Case Western Reserve University

The University of Chicago

University of Cincinnati

Illinois Institute of Technology

University of Illinois

Indiana University

Iowa State University

The University of Iowa
Kansas State University The University of Kansas Loyola University Marquette University Michigan State University The University of Michigan University of Minnesota University of Missouri Northwestern University University of Notre Dame
The Ohio State University Ohio University

The Pennsylvania State University Purdue University Saint Louis University Southern Illinois University The University of Texas at Austin Washington University Wayne State University The University of Wisconsin

\section{NOTICE}

This report was prepared as an account of work sponsored by the United States Government. Neither the United States nor the United States Energy Research and Development Administration, nor any of their employees, nor any of their contractors, subcontractors, or their employees, makes any warranty, express or implied, or assumes any legal liability or responsibility for the accuracy, completeness or usefulness of any information, apparatus, product or process disclosed, or represents that its use would not infringe privately-owned rights. Mention of commercial products, their manufacturers, or their suppliers in this publication does not imply or connote approval or disapproval of the product by Argonne National Laboratory or the U. S. Energy Research and Development Administration.

Printed in the United States of America Available from

National Technical Information Service

U. S. Department of Commerce 5285 Port Royal Road

Springfield, Virginia 22161

Price: Printed Copy $\$ 6.50$; Microfiche $\$ 3.00$ 
Distribution Category:

Water Reactor Safety Research- -

Fuel Behavior (NRC-3)

ANL- $77-30$

\section{ARGONNE NATIONAL LABORATORY}

9700 South Cass Avenue

Argonne, Illinois 60439

UNIAXIAL TENSILE PROPERTIES

OF ZIRCALOY CONTAINING OXYGEN:

SUMMARY REPOR T

by

A. M. Garde; H. M. Chung, and T. F. Kassner

Materials Science Division

June 1977

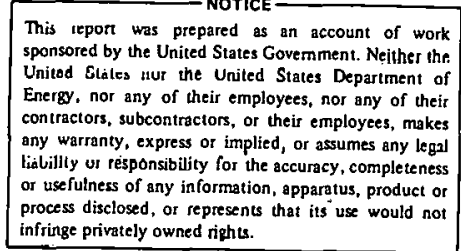




\section{THIS PAGE}

WAS INTENTIONALLY

LEFT BLANK 
TABLE OF CONTENTS

Page

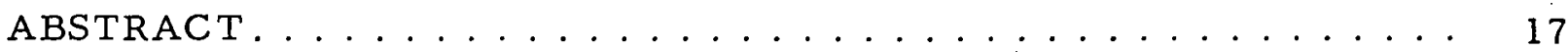

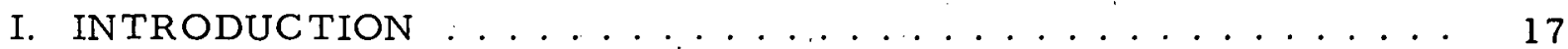

II. MATERIALS, APPARATUS, AND PROCEDURES $\ldots \ldots \ldots \ldots$

A. Materials ......................... 18

B. Tensile-specimen Geometry . . . . . . . . . . . . . . 19

C. Oxygen Charging and Homogenization ............. 20

1. Oxygen-charging and Homogenization Furnace...... 20

2. Oxidation Procedure ................. 21

3. Homogenization Procedure.............. 22

D. Mechanical Testing Facility ................ 22

E. Metallography and Specimen Characterization ........ 23

F. Work-hardening Analysis . ................ 23

G. Strain-rate-sensitivity Determination . . . . . . . . 24

III. MECHANICAL PROPERTIES OF ZIRCALOY $-2 \ldots \ldots \ldots \ldots . . \ldots 24$

A. As-received Zircaloy $-2 \ldots \ldots \ldots \ldots 24 \ldots \ldots \ldots$

1. Stress-Strain Curves . . . . . . . . . . . . 24

2. Strain-rate Sensitivity . . . . . . . . . . . . 26

3. Work-hardening Analysis................. 28

4. Superplasticity . . . . . . . . . . . . . . . . 30

5. Dynamic Strain Aging in Zircaloy near $700^{\circ} \mathrm{C} \ldots \ldots 30$

B. Zircaloy-2/Oxygen Alloys ................... 31

IV. MECHANICAL PROPERTIES OF ZIRCALOY $-4 \ldots \ldots \ldots 33$

A. As-received $\mathrm{Zircaloy}-4 \ldots \ldots \ldots \ldots \ldots \ldots \ldots \ldots$

1. Stress-Strain Curves . . . . . . . . . . . . 33

2. Strain-rate Sensitivity . . . . . . . . . ... 36

3. Work-hardening Analysis. . . . . . . . . . . . . 39

4. Effect of Texture on the Mechanical Properties . . . . . . 43

5. Fine-grain-size $\mathrm{Zircaloy-4 \ldots \ldots \ldots . \ldots . \ldots 47}$

6. Influence of Specimen Geometry . . . . . . . . . . 51

7. Effect of Grain Size on Tensile Properties ......... 53 
TABLE OF CONTENTS

$\underline{\text { Page }}$

8. Influence of Microstructural State . . . . . . . . 54

9. Dynamic Strain Aging near $750^{\circ} \mathrm{C} \ldots \ldots \ldots \ldots 65$

10. Comparison of Zircaloy-4 Tensile Properties of Stressrelieved Tubing and Recrystallized Sheet . . . . . . . 72

V. PROPERTIES OF ZIRCALOY-4/OXYGEN ALLOYS . . . . . . 74

A. Homogeneous Oxygen Distribution . . . . . . . . . . . 74

B. Composite Material with Oxygen Gradients in $\alpha$ and $\beta$ Phases. . 83

C. Effect of Cooling Rate on Properties of Composite Specimens 90

VI. ACTIVATION ENERGY FOR HIGH-TEMPERATURE DEFORMATION OF ZIRCALOY . . . . . . . . . . . . . 92

VII. SUPER PLASTICITY OF ZIRCALOY. . . . . . . . . . . . . 94

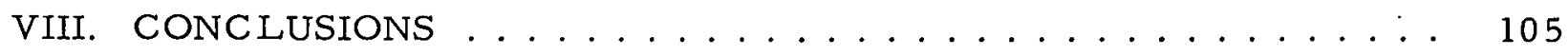

ACKNOWLEDGMENTS . . . . . . . . . . . . . . . 105

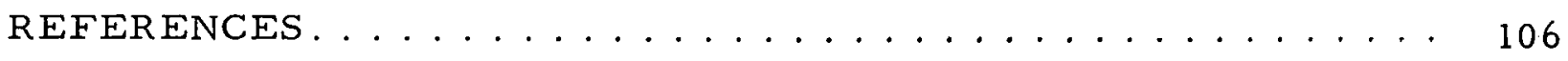




\section{LIST OF FIGURES}

No.

Title

Page

1. Engineering-stress/Engineering-strain Curves for As-received Zircaloy-2 Specimens Deformed at Temperatures between 750

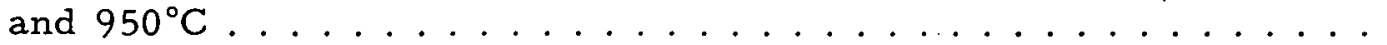

2. Engineering-stress/Engineering-strain Curves for As-received Zircaloy-2 Specimens Deformed at Temperatures between 1000 and $1400^{\circ} \mathrm{C}$

3. Effect of Temperature on $0.2 \%$ Yield Stress and Ultimate Tensile Strength of As-received Zircaloy-2.

4. Effect of Deformation Temperature on Uniform, Necking, and Total Strains for Zircaloy-2 Specimens ............ 26

5. Strain Dependence of Strain-rate Sensitivity of Zircaloy-2 at Temperatures between 700 and $1400^{\circ} \mathrm{C}$ for Strains below $\sim 0.2 \ldots$

6. Strain Dependence of Strain-rate Sensitivity of Zircaloy-2 at $700,800,850$, and $900^{\circ} \mathrm{C}$ for Strains to $1.3 \ldots \ldots \ldots$

7. Effect of Strain Rate on Strain Dependence of Strain-rate Sensitivity of Zircaloy -2 at $900^{\circ} \mathrm{C} \ldots \ldots \ldots \ldots$

8. Temperature Dependence of Strain-rate Sensitivity of Zircaloy-2

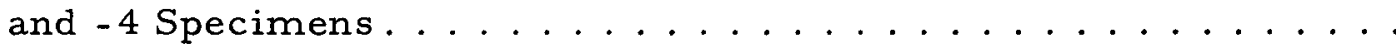

9. Crussard-Jaoul Plots for Zircaloy-2 Specimens Deformed at 900 , 1100,1200 , and $1400^{\circ} \mathrm{C} \ldots \ldots \ldots \ldots$

10. Temperature Dependence of Work-hardening Exponent Obtained from Zircaloy-2 Tensile Data . . . . . ...........

11. Comparison between a Zircaloy-2 Specimen Strained under Superplastic Conditions and an Undeformed Specimen . . . . . . . . .

12. Partial Load-elongation Curves for Zircaloy-2 Specimens Deformed at $700^{\circ} \mathrm{C}$ after Various Heat Treatments . . . . . . . .

13. Uniform and Total Strain as a Function of Oxygen Concentration for Zircaloy-2 Specimens at 1300 and $1400^{\circ} \mathrm{C} \ldots \ldots . . .$.

14. Oxygen-concentration Dependence of Yield Stress and Ultimate Tensile Strength of Zircaloy -2 at 1300 and $1400^{\circ} \mathrm{C} \ldots \ldots$. . . .

15. Total Strain, Uniform Strain, Yield Stress, and Ultimate Tensile Strength of Zircaloy-2 at $1300^{\circ} \mathrm{C}$ as a Function of Oxygen

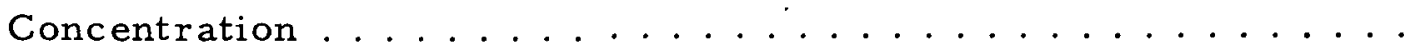

16. Engineering-stress/Engineering-strain Curves for Zircaloy-4 Specimens Deformed at $700,750,850,900$, and $950^{\circ} \mathrm{C} \ldots \ldots$ 


\section{LIST OF FIGURES}

No.

Title

$\underline{\text { Page }}$

17. Engineering-stress/Engineering-strain Curves for Zircaloy-4 Specimens Deformed at $900,950,1000,1100,1200,1300$, and $1400^{\circ} \mathrm{C}$.

18. Engineering-stress/Engineering-strain Curves for Zircaloy-4 Specimens Deformed at 700,800 , and $900^{\circ} \mathrm{C} \ldots \ldots$

19. Engineering-stress/Engineering-strain Curves for Zircaloy-4 Specimens Deformed at $1000,1100,1200,1300$, and $1400^{\circ} \mathrm{C} \ldots$.

20. Ultimate Tensile Strength of Zircaloy-4 at Three Strain Rates over Two Temperature Intervals . . . . . . . . . . . . . 34

21. Uniform Strain and Total Strain for Zircaloy-4 Specimens as a Function of Deformation Temperature at Three Strain Rates . . .

22. True-stress/True-strain Curve for Zircaloy-4 Specimen Deformed at $900{ }^{\circ} \mathrm{C} \ldots \ldots \ldots \ldots$

23. Strain Dependence of Strain-rate Sensitivity of Zircaloy-4

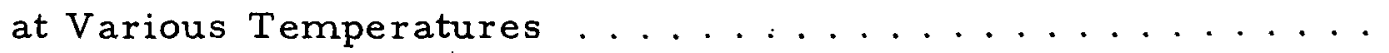

24. Strain Dependence of Strain-rate Sensitivity of Zircaloy-4 at $700,800,850$, and $900^{\circ} \mathrm{C} \ldots \ldots \ldots$

25. Effect of Strain and Strain Rate on Strain-rate Sensitivity of Lircaloy -4 at $800, y 00$, and $1000^{\circ} \mathrm{C} \ldots \ldots \ldots$

26. Strain-rate Dependence of Strain-rate Sensitivity of Zircaloy at 800,900 , and $1000^{\circ} \mathrm{C} \ldots \ldots \ldots$

27. Strain-rate Sensitivity of As-received Zircaloy-4 at $850^{\circ} \mathrm{C}$ as a Function of $\operatorname{Strain} \ldots \ldots \ldots \ldots$

28. Plots of $\log (d \sigma / d \epsilon)$ vs $\log \epsilon$ for Zircaloy-4 Specimens Deformed at $700,1000,1100,1300$, and $1400^{\circ} \mathrm{C} \ldots \ldots$

29. Work-hardening Exponent as a Function of Temperature for Zircaloy -4 at Four Strain Rates .................

30. Temperature Dependence of Parameter $k$ for Zircaloy-4 at Threc Strain Rates......................

31. Variation of $\sigma_{0}$ with Temperature for Zircaloy-4 at Three Strain Rates.

32. Effect of Texture on Uniform Strain of Zircaloy-4 at Temperatures between Ambient and $1400^{\circ} \mathrm{C} \ldots \ldots \ldots$

33. Influence of Texture on Total Strain of Zircialoy-4 at Temperatures between Ambient and $1400^{\circ} \mathrm{C} \ldots \ldots \ldots$ 


\section{LIST OF FIGURES}

No.

Title

Page

34. Temperature Dependence of Ultimate Tensile Strength for Longitudinal, Transverse, and Diagonal Zircaloy-4 Specimens...

35. Strain-rate Sensitivity of Longitudinal and Transverse Zircaloy-4 Specimens as a Function of Temperature ........

36. Strain Dependence of Strain-rate Sensitivity of Transverse and Longitudinal Zircaloy- 4 Specimens at $850^{\circ} \mathrm{C} \ldots \ldots \ldots$

37. Work-hardening. Exponent as a Function of Temperature for Zircaloy-4 Specimens with Three Textures ...........

38. Total Strain as a Function of Temperature for $5-\mu \mathrm{m}$ Grain-size Zircaloy-4 Specimens at Three Strain Rates. . . . . . . . . .

39. Strain-rate Sensitivity of Fine-grain Zircaloy-4 as a Function

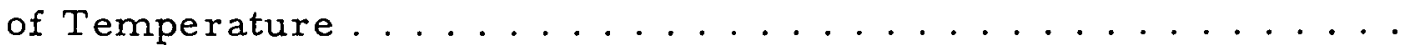

40. Effect of Strain Rate on Total and Uniform Strain of Zircaloy-4

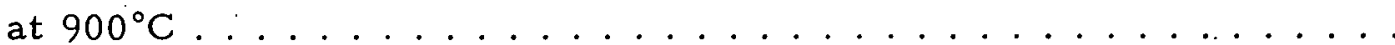

41. Strain-rate Dependence of Strain-rate Sensitivity of Zircaloy-4

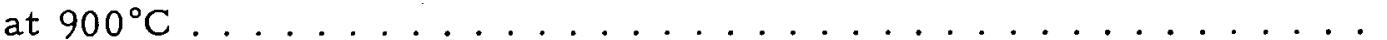

42. Work-hardening Exponent of Fine-grain-size Zircaloy-4 as a Function of Temperature at Three Strain Rates . . . . . . . . .

43. Effect of Width-to-Thickness Ratio of Tensile Specimen on Strain-rate Dependence of Strain-rate Sensitivity of Zircaloy-4

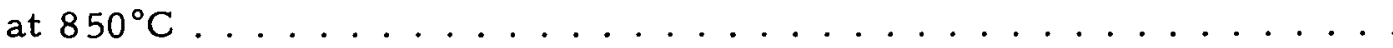

44. Dependence of Total Strain on Strain Rate for 11 - and $50-\mu \mathrm{m}$ Grain-size Zircaloy-4 Specimens at $850^{\circ} \mathrm{C} \ldots \ldots \ldots$

45. Strain-rate Dependence of Total Strain of 5- and 11- $\mu \mathrm{m}$ rrainsize Zircaloy-4 Specimens at $850^{\circ} \mathrm{C}$

46. Variation of Uniform Strain with Strain Rate for 5- and 11- $\mu \mathrm{m}$ Grain-size Zircaloy-

47. Yield Stress as a Function of Grain Size for Zircaloy -4 at $850^{\circ} \mathrm{C}$.

48. Effect of Hold 'l'ime before Deformation on l'otal Strain of

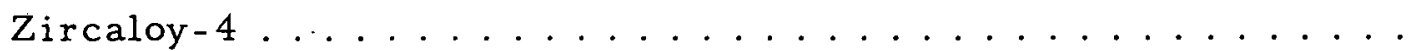

49. Microstructure of a $\mathrm{Zircaloy}-4$ Specimen Oil-quenched from $850^{\circ} \mathrm{C}$ after 0.6 -ks Hold Time. . . . . . . . . . . .

50. Microstructure of a Zircaloy-4 Specimen Oil-quenched from $850^{\circ} \mathrm{C}$ after 7.2 -ks Hold Time. 


\section{LIST OF FIGURES}

No

Title

$\underline{\text { Page }}$

51. Microstructure of As-received Zircaloy-4 after Cooling through $\beta \rightarrow \alpha^{\prime}$ Transformation at $0.1^{\circ} \mathrm{C} / \mathrm{s}$ from $1000^{\circ} \mathrm{C} \ldots \ldots . . .$.

52. Parallel-plate Structure of As-received Zircaloy-4 after Cooling through $\beta \rightarrow \alpha^{\prime}$ Transformation at $\sim 2^{\circ} \mathrm{C} / \mathrm{s}$ from $1250^{\circ} \mathrm{C} \ldots \ldots$

53. Basketweave Structure of As-received Zircaloy-4 after Cooling through $\beta \rightarrow \alpha^{\prime}$ Transformation at $\sim 500^{\circ} \mathrm{C} / \mathrm{s}$ from $1000^{\circ} \mathrm{C} \ldots \ldots$

54. Martensitic Structure of As-received Zircaloy-4 after Cooling through $\beta \rightarrow \alpha^{\prime}$ Transformation at $\sim 10,000^{\circ} \mathrm{C} / \mathrm{s}$ from $1000^{\circ} \mathrm{C}$. . . .

55. Effect of $\alpha$-phase Morphology on Engineering-stress/Engineeringstrain Curve of Zircaloy -4 at $400^{\circ} \mathrm{C} \ldots \ldots \ldots \ldots$

56. SEM Fractograph of As-received Zircaloy-4 Specimen Fractured at $400^{\circ} \mathrm{C} ; \dot{\varepsilon}=3.3 \times 10^{-3} \mathrm{~s}^{-1} \ldots \ldots \ldots \ldots$

57. SEM Fractograph of Transformed $\beta$-phase Zircaloy-4 Specimen Fractured at $400^{\circ} \mathrm{C} ; \dot{\varepsilon}=3.3 \times 10^{-3} \mathrm{~s}^{-1} \ldots \ldots \ldots$

58. Influence of $\alpha$-phase Morphology on Total Strain of Zircaloy-4 at Temperatures between Ambient and $950^{\circ} \mathrm{C} \ldots \ldots \ldots$

59. Temperature Dependence of Ultimate Tensile Strength of Zircaloy-4 with Equiaxed and Basketweave Microstructures ....

60. Strain-rate Sensitivity as a Function of Temperature for Zircaloy- 4 Specimens with Equiaxed Grains and Basketweave Structure $; \varepsilon=0.02 \ldots \ldots \ldots$

61. Strain-rate Dependence of Strain-rate Sensitivity of Zircaloy-4 with Equiaxed Grains and Basketweave Structure at $850^{\circ} \mathrm{C}$;

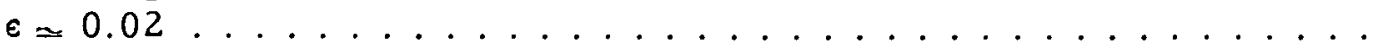

62. Temperature Dependence of Ultimate Tensile Strength of Transformed $\beta$-phase Basketweave Zircaloy -4 at Two Strain

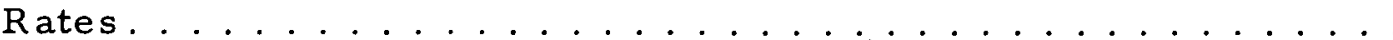

63. Effect of Strain Rate on Total Strain of Zircaloy-4 with Basketweave Structure at Temperatures between Ambient and $1000^{\circ} \mathrm{C}$. .

64. Ultimate Tensile Strength as a Function of Temperature for Transformed $\beta$-phase Zircaloy- 4 with Basketweave and Parallelplate Structures.......................

65. Temperature Dependence of Total Strain of Transformed $\beta$-phase Zircaloy-4 with Basketweave and Parallel-plate Structures.....

66. Effect of Cooling Rate on Yield Stress of Transformed $\beta$-phase Zircaloy -4 at Several Temperatures ............... 


\section{LIST OF FIGURES}

No.

Title

Page

67. Influence of Cooling Rate on Ultimate Tensile Strength of Transformed $\beta$-phase Zircaloy-4 at Several Temperatures . . . . .

68. Cooling-rate Dependence of Uniform Strain of Transformed $\beta$-phase Zircaloy- 4 at Several Temperatures . . . . . . . . . 62

6.9. Total Strain as a Function of Cooling Rate for Transformed $\beta$-phase Zircaloy-4 at Several Temperatures . . . . . . . . 63

70. Uniform Strain vs Temperature for Transformed $\beta$-phase Zircaloy-4 at Various Cooling Rates . . . . . . . . . . .

71. Total Strain as a Function of Temperature for Transformed ß-phase Zircaloy-4 at Various Cooling Rates . . . . . . . . . 64

72. Temperature Dependence of Work-hardening Exponent of Various Transformed $\beta$-phase Zircaloy-4 Structures. . . . . . . . . . .

73. Work-hardening Exponent of Basketweave-structure Zircaloy-4 as a Function of Temperature at Two Strain Rates. . . . . . . . .

74. Partial Load-elongation Curves for Zircaloy-4 Specimens Deformed at $750^{\circ} \mathrm{C}$ after Various Heat Treatments . . . . . . . .

75. Strain-rate Dependence of Work-hardening Exponent of Zircaloy at $700^{\circ} \mathrm{C}$

76. Engineering-stress/Engineering-strain Curves for Zircaloy-4 at $750^{\circ} \mathrm{C}$ after Various Heat $\mathrm{Treatments} \ldots \ldots \ldots \ldots$

77. Strain Dependence of Strain-rate Sensitivity of Zircaloy-4 at $750^{\circ} \mathrm{C}$ after Two Heat Treatments . . . . . . . . . . .

78. Ultimate Tensile Strength and Yield Stress of Zircaloy-4 Stressrelieved Tube and Recrystallized Shoot ac a Function of Temperature. . ....................

79. Total Strain of Zircaloy-4 Tube and Recrystallized Sheet as a Function of Temperature...................

80. Uniform Strain of Zircaloy-4 Tube and Recrystallized Sheet as a

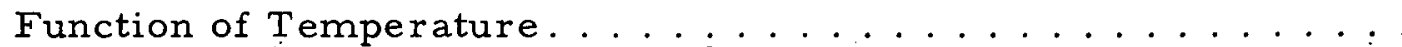

81. Effect of Oxygen on Ultimate Tensile Strength of Zircaloy-4 at Several Temperatures between 200 and $1100^{\circ} \mathrm{C} \ldots \ldots \ldots$

82. Variation of Ultimate Tensile Strength of Zircaloy -4 with Oxygen Concentration at 1200,1300 , and $1400^{\circ} \mathrm{C} \ldots \ldots \ldots \ldots$

83. Oxygen-concentration Dependence of Uniform Strain of Zircaloy-4 at Several Teriperalures . . . . . . . . . . 


\section{LIST OF FIGURES}

No

Title

Page

84. Oxygen-concentration Dependence of Uniform Strain of Zircaloy -4 at 1200,1300 , and $1400^{\circ} \mathrm{C} \ldots \ldots \ldots$

85. Total Strain of Zircaloy-4 as a Function of Oxygen Concentration

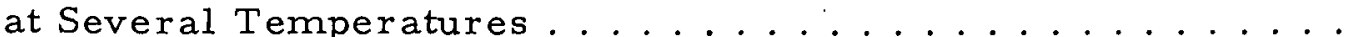

86. Effect of Oxygen Concentration on Total Strain of Zircaloy-4 at 1200,1300 , and $1400^{\circ} \mathrm{C} \ldots \ldots \ldots \ldots$

87. Effect of Oxygen on Temperature Dependence of Total Strain of Zircaloy $-4 \ldots \ldots \ldots \ldots$

88. Pseudobinary Zircaloy Oxygen Phase Diagram Determined from Metallographic and Resistivity Measurements . . . . . . .

89. SEM Fractograph of Zircaloy-4 Specimen with 2.3 wt \% Oxygen Fractured at $850^{\circ} \mathrm{C} ; \dot{\varepsilon}=3.3 \times 10^{-3} \mathrm{~s}^{-1} \ldots \ldots \ldots$

90. Work-hardening Exponent of Zircaloy-4 at $1000^{\circ} \mathrm{C}$ as a Function

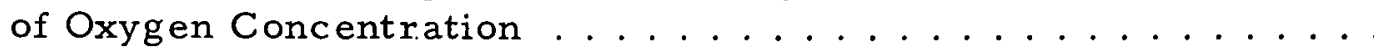

91. Work-hardening Exponent of Zircaloy-4 at $1100^{\circ} \mathrm{C}$ as a Function

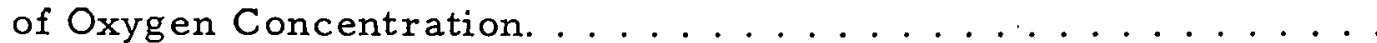

92. Work-hardening Exponent of Zircaloy-4 at $1200^{\circ} \mathrm{C}$ as a Function of Oxygen Concentration. . . . . . . . . . . . . . . . .

93. Work-hardening Exponent of Zircaloy-4 at $1300^{\circ} \mathrm{C}$ as a Function

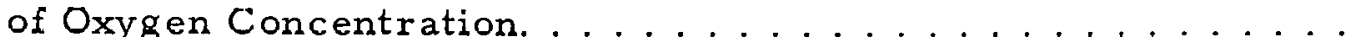

94. Work-hardening Exponent of Zircaloy-4 at $1400^{\circ} \mathrm{C}$ as a Function

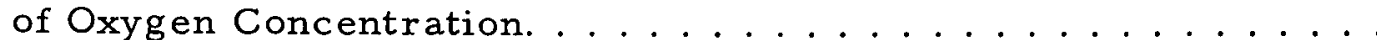

95. Temperature Dependence of Work-hardening Exponent of Zircaloy-4 with Several Oxygen Concentrations . . . . . . . .

96. Strain Dependence of Strain-rate Sensitivity of Zircaloy-4 with 0.5 wt $\%$ Oxygen at 700 and $850^{\circ} \mathrm{C} \ldots \ldots \ldots$

97. Effect of Strain on Strain-rate Sensitivity of Zircaloy-4 at

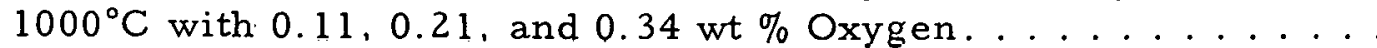

98. Effect of Strain on Strain-rate Sensitivity of Zircaloy-4 with $0.11,0.22$, and 0.35 wt $\%$ Oxygen at $1200^{\circ} \mathrm{C} \ldots \ldots$

99. Effect of Strain on Strain-rate Sensitivity of Zircaloy-4 with 0.25 wt $\%$ Oxygen at 1000,1200 , and $1400^{\circ} \mathrm{C} \ldots \ldots \ldots$

100. Strain Dependence of Strain-rate Sensitivity of Zircaloy-4 with $0.11,0.2$, and 1.0 wt $\%$ Oxygen at $1400^{\circ} \mathrm{C}$ 


\section{LIST OF FIGURES}

No.

Title

Page

101. Oxygen-concentration Dependence of Strain-rate Sensitivity of Zircaloy -4 at 1200,1300 , and $1400^{\circ} \mathrm{C} \ldots \ldots \ldots$

102. Temperature Dependence of Total Strain of Homogenized and Composite Zircaloy -4 with 0.8 wt $\%$ Oxygen. . . . . . . . .

103. Ultimate Tensile Strength as a Function of Temperature for Homogenized and Composite Zircaloy -4 with 0.8 wt \% Oxygen. .

104. Strain Dependence of Strain-rate Sensitivity of Zircaloy-4/ Oxide Composites with 0.78 and 1.00 wt \% Total Oxygen at

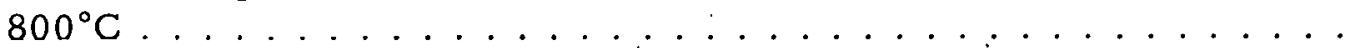

105. Strain-rate Sensitivity as a Function of Strain for Zircaloy-4/ Oxide Composites with 0.43 and 0.82 wt $\%$ Total Oxygen at

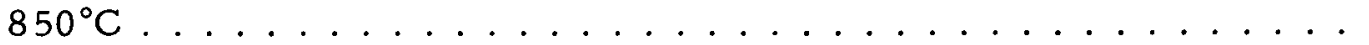

106. Strain-rate Sensitivity as a Function of Strain for Zircaloy-4/ Oxide Composites with $0.77,1.12$, and 1.88 wt $\%$ Total Oxygen at $900^{\circ} \mathrm{C} \ldots \ldots \ldots \ldots \ldots \ldots$

107. Strain Dependence of Strain-rate Sensitivity of Zircaloy-4/

Oxide Composites with 0.78 and 1.17 wt \% Total Oxygen at

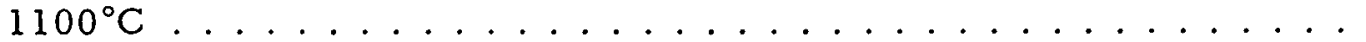

108. Strain-rate Sensitivity of Zircaloy-4/Oxide Composites as a Function of Total Oxygen Concentration at 850,900 , and $1100^{\circ} \mathrm{C}$.

109. Microstructure of Zircaloy-4/Oxide Composite Specimen Deformed at $800^{\circ} \mathrm{C}$ Showing Cracks in. Oxide and $\alpha$ Layers . . . . . .

110. Microstructure of Zircaloy-4/Oxide Composite Specimen Deformed at $1100^{\circ} \mathrm{C}$ Showing No Cracks in $\alpha$ Layer . . . . . . ...

11. Nxygen-concentration Dependencc of Yield Stress of Zircialoy-4/ Oxide Composites at Several Temperatures. . . . . . . . . .

112. Ultimate Tensile Strength of Zircaloy-4/Oxide Composites as a Function of Oxygen Concentration at Several Temperatures . . .

113. Effect of Oxygen Concentration on Uniform Strain of Zircaloy-4/ Oxide Composites at Several Tcmpcratures. . . . . . . . .

114. Variation of Total Strain of Zircaloy-4/Oxide Composites with Oxygen Concentration at Several Temperatures ..........

115. Temperature Dependence of Work-hardening Exponent of Zircaloy -4/Oxide Composites with Several Oxygen

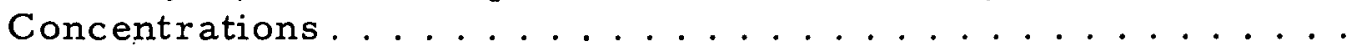




\section{LIST OF FIGURES}

No.

Title

$\underline{\text { Page }}$

116. Uniform and Total Strain of Zircaloy-4/Oxide Composites with 4.0 wt \% Oxygen as a Function of Cooling Rate .......

117. Ultimate Tensile Strength and Yield Stress as a Function of Cooling Rate for Zircaloy-4/Oxide Composites with 4.0 wt \%

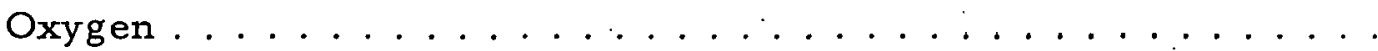

118. Effect of Cooling Rate on Yield Stress and Ultimate Tensile Strength of Composite Zircaloy-4 Specimens with 4.4 wt \%

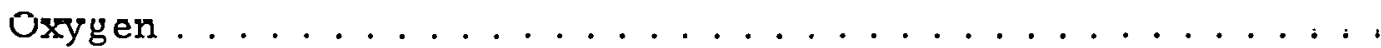

119. Influence of Cooling Rate on Uniform and Totai Strain of Composite Lircaloy-4 Specımens with 4.4 wit \% Oxygen......

120. Strain-rate Dependence of $0.2 \%$ Yield Stress of $5-\mu \mathrm{m}$ Grainsize Zircaloy-4 at Several Temperatures between 700 and $950^{\circ} \mathrm{C}$.

121. Strain-rate Dependence of $0.2 \%$ Yield Stress of 11- $\mu \mathrm{m}$ Grainsize Zircaloy-4 at Several Temperatures between 700 and

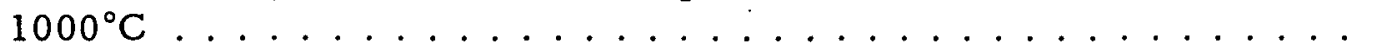

122. Temperature Dependence of Strain Rate for Stage-III Deformation of $5-\mu \mathrm{m}$ Grain-size Zircaloy-4 . . . . . . . . . .

123. Temperature Dependence of Strain Rate for Stage-III Deformation of 11- $\mu \mathrm{m}$ Grain-size Zircaloy-4 ...........

124. Microstructure near Shoulder Region and Fracture Region of a Zircaloy-4 Specimen Deformed at $850^{\circ} \mathrm{C}$ at a Strain Rate of $3.3 \times 10^{-3} \mathrm{~s}^{-1} \ldots \ldots \ldots \ldots \ldots$

125. Microstructure of an 11- $\mu \mathrm{m}$ Grain-size Specimen Deformed to $0.7 \mathrm{Strain}$ at a Strain Rate of $3.0 \times 10^{-1} \mathrm{~s}^{-1}$ at $850^{\circ} \mathrm{C} \ldots \ldots$

126. Microstructure of a $5-\mu \mathrm{m}$ Grain-size Specimen Deformed to $\sim 1.5 \mathrm{Str}$ ain at a Strain Rate of $6.0 \times 10^{-6} \mathrm{~s}^{-1}$ at $850^{\circ} \mathrm{C} \ldots . .$.

127. SEM Fractograph of a Zircaloy -4 Specimen Fractured at $800^{\circ} \mathrm{C}$; $\dot{\varepsilon}=3.3 \times 10^{-2} \mathrm{~s}^{-1} \ldots \ldots \ldots \ldots$

128. SEM Fractograph of a Zircaloy -4 Specimen Fractured at $950^{\circ} \mathrm{C}$; $\dot{\epsilon}=3.3 \times 10^{-3} \mathrm{~s}^{-1}$.

129. Micrograph of Scratched Surface of a 5- $\mu \mathrm{m}$ Grain-size Zircaloy-4 Specimen Deformed at a Strain Rate of $3.3 \times 10^{-4} \mathrm{~s}^{-1}$ at $900^{\circ} \mathrm{C}$ Showing Offsets of Inscribed Scratches at Grain

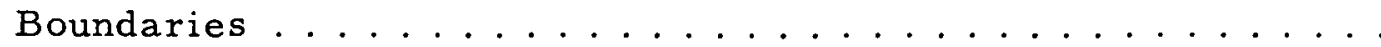

130. Strain-rate Dependence of Work-hardening Exponent of Zircaloy -4 at $850^{\circ} \mathrm{C}$ 
No.

131. Logarithmic Plot of Strain Rate as a Function of Grain Size for Stage-II Deformation of Zircaloy -4 at $850^{\circ} \mathrm{C} \ldots \ldots \ldots 101$

132. Comparison of Calculated and Experimental Strain-rate Dependence of $0.2 \%$ Yield Stress for 5- and $11-\mu \mathrm{m}$ Grain-size Zircaloy -4 at 850 and $900^{\circ} \mathrm{C} \ldots \ldots \ldots 102$

133. Slip Lines on Surface of a Zircaloy-4 Specimen Deformed at

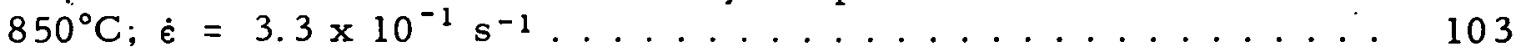

134. Facets due to Thermal Etching of Surface of a Zircaloy-4 Specimen Deformed at $850^{\circ} \mathrm{C} ; \dot{\varepsilon}=3.3 \times 10^{-6} \mathrm{~s}^{-1} \ldots \ldots \ldots 104$ 


\section{LIST OF TABLES}

No.

Title

I. Source and Composition of Zircaloy-2 and -4 Materials Used in Fabrication of Uniaxial Test Specimens . . . . . . . . . . .

II. Summary of Oxidation and Homogenization Conditions for Zircaloy Test Specimens. . . . . . . . . . . . . .

III. Least-squares Work-hardening Constants for Deformation Stages of As-received Longitudinal Zircaloy-2 Specimens from Crussard-Jaoul Analysis . . . . . . . . . . . . . .

IV. Effect of Oxygen on Least-squares Work-hardening Constants for Deformation Stages of Longitudinal $\beta$-pliase $Z$ Zilialoy $=2$ Spccimcno from Cruooard Jaoul Analysis; $\dot{s}=3.3 \times 10^{-3} s^{-1}$.

V. Least-squares Work-hardening Constants for Deformation Stages of As-received Longitudinal Zircaloy-4 Specimens from Crussard-Jaoul Analysis; $\dot{\varepsilon}=3.3 \times 10^{-2} \mathrm{~s}^{-1} \ldots \ldots$

VI. Least-squares Work-hardening Constants for Deformation Stages of As-received Longitudinal Zircaloy-4 Specimens from Crussard-Jaoul Analysis; $\dot{\epsilon}=3.3 \times 10^{-3} \mathrm{~s}^{-1} \ldots \ldots$.....

VII. Least-squares Work-hardening Constants for Deformation Stages of As-received Longitudinal Zircaloy-4 Specimens from Crussard-Jaoul Analysis; $\dot{\varepsilon}=3.3 \times 10^{-4} \mathrm{~s}^{-1} \ldots \ldots . .$.

VIII. Least-squares Work-hardening Constants for Deformation Stages of As-received Transverse Zircaloy-4 Specimens;

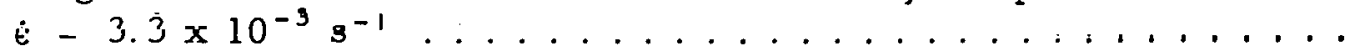

IX. Least-squares Work-hardening Constants for Deformation Stages of As-recerved Diagonal Zircaloy-4 Specimens; $\dot{\epsilon}=3.3 \times 10^{-3} \mathrm{~s}^{-1} \ldots \ldots \ldots \ldots \ldots$

$X$. Least-squares Work-hardening Constants for Deformation Stages of $5-\mu \mathrm{m}$ Grain-size Zircaloy-4; $\dot{\varepsilon}=3.3 \times 10^{-2} \mathrm{~s}^{-1} \ldots .$.

XI. Least-squares Work-hardening Constants for Deformation Stages of $5-\mu \mathrm{m}$ Grain-size Zircaloy-4; $\dot{\varepsilon}=3.3 \times 10^{-3} \mathrm{~s}^{-1} \ldots .$.

XII. Least-squares Work-hardening Constants for Deformation Stages of $5-\mu \mathrm{m}$ Grain-size Zircaloy-4; $\dot{\varepsilon}=3.3 \times 10^{-4} \mathrm{~s}^{-1} \ldots .$.

XIII. Least-squares Work-hardening Constants for Deformation Stages of Transformed $\beta$-phase Zircaloy-4; Cooling Rate $\approx 0.1^{\circ} \mathrm{C} / \mathrm{s} ; \dot{\epsilon}=3.3 \times 10^{-3} \mathrm{~s}^{-1} \ldots \ldots \ldots \ldots$

XIV. Least-squares Work-hardening Constants for Deformation Stages of Longitudinal Zircaloy-4 Specimens with Parallelplate Structure; Cooling Rate $\simeq 1^{\circ} \mathrm{C} / \mathrm{s} ; \dot{\epsilon}=3.3 \times 10^{-3} \mathrm{~s}^{-1} \ldots \ldots$ 


\section{LIST OF TABLES}

No.

Title

Page

XV. Least-squares Work-hardening Constants for Deformation Stages of Longitudinal Zircaloy-4 Specimens with Basketweave Structure; Cooling Rate $\simeq 3^{\circ} \mathrm{C} / \mathrm{s} ; \dot{\varepsilon}=3.3 \times 10^{-3} \mathrm{~s}^{-1} \ldots 66$

XVI. Least-squares Work-hardening Constants for Deformation Stages of Longitudinal Zircaloy-4 Specimens with Martensitic Structure; Cooling Rate $\approx 10,000^{\circ} \mathrm{C} / \mathrm{s} ; \dot{\epsilon}=3.3 \times 10^{-3} \mathrm{~s}^{-1}$.

XVII. Least-squares Work-hardening Constants for Deformation Stages of Longitudinal Zircaloy-4 Specimens with Basketweave Structure; Cooling Rate $\simeq 3^{\circ} \mathrm{C} / \mathrm{s} ; \ddot{\epsilon}=3.3 \times 10^{-5} \mathrm{~s}^{-1} \ldots$

XVIII. Least-squares Work-hardening Constants for Longitudinal Zircaloy-2 Specimens Deformed at $700^{\circ} \mathrm{C}$ and Various Strain

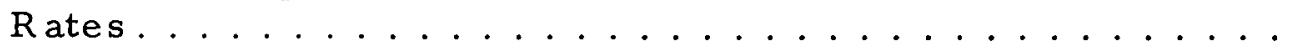

XIX. Least-squares Work-hardening Constants for 5- $\mu \mathrm{m}$ Grainsize Longitudinal Zircaloy-4 Specimens Deformed at $700^{\circ} \mathrm{C}$

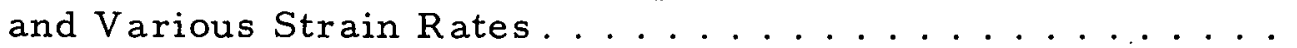

XX. Least-squares Work-hardening Constants for $11-\mu \mathrm{m}$ Grainsize Longitudinal Zircaloy-4 Specimens Deformed at $700^{\circ} \mathrm{C}$ and Various Strain Rates..................

XXI. Least-squares Work-hardening Constants for $11-\mu \mathrm{m}$ Grainsize Longitudinal Zircaloy-4 Specimens Deformed at $750^{\circ} \mathrm{C}$ after Various Heat Treatments; $\dot{\varepsilon}=3.3 \times 10^{-3} \mathrm{~s}^{-1} \ldots \ldots$.

XXII. Least-squares Work-hardening Constants for Longitudinal Specimens of Zircaloy-4/Oxygen Alloys; $\dot{\varepsilon}=3.3 \times 10^{-3} \mathrm{~s}^{-1}$.

XXIII. Least-squares Work-hardening Constants for Longitudinal Specimens of Zircaloy-4/Oxygen Alloys; $\dot{\varepsilon}=3.3 \times 10^{-4} \mathrm{~s}^{-1}$.

XXIV. Least-squares Work-hardening Constants for Longitudinal Specimens of Zircaloy-4/Oxygen Alloys; $\dot{\varepsilon}=3.3 \times 10^{-5} \mathrm{~s}^{-1}$.

XXV. Effect of Oxygen Concentration on Least-squares Workhardening Constants of Longitudinal Equiaxed $\alpha$-phase Zircaloy -4 Specimens; $\dot{\epsilon}=3.3 \times 10^{-3} \mathrm{~s}^{-1} \ldots \ldots . . . .$.

XXVI. Least-squares Work-hardening Constants for Zircaloy-4/ Oxide Composite Specimens; $\dot{\varepsilon}=3.3 \times 10^{-3} \mathrm{~s}^{-1} \ldots \ldots . .$.

XXVII. Least-squares Work-hardening Constants for 5- $\mu \mathrm{m} \mathrm{Grain-}$ size Zircaloy-4 Specimens Deformed at $850^{\circ} \mathrm{C}$ and Various

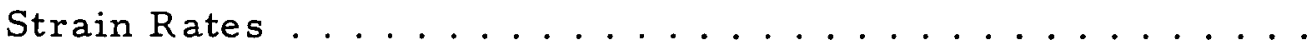


No.

Title

$\underline{\text { Page }}$

XXVIII. Least-squares Work-hardening Constants for 11- $\mu \mathrm{m}$ Grainsize Zircaloy -4 Specimens Deformed at $850^{\circ} \mathrm{C}$ and Various Strain Rates ..................... 100

XXIX. Least-squares Work-hardening Constants for 50- $\mu \mathrm{m}$ Grainsize Zircaloy- 4 Deformed at $850^{\circ} \mathrm{C}$ and Various Strain Rates. 100 
UNIAXIAL TENSILE PROPERTIES

OF ZIRCALOY CONTAINING OXYGEN: SUMMARY REPORT

\author{
A. M. Garde, H. M. Chung, \\ and T. F. Kassner
}

\begin{abstract}
The uniaxial stress-strain behavior of Zircaloy -2 and -4 , Zircaloy-oxygen alloys with a uniform oxygen distribution, and composite specimens with a $\mathrm{ZrO}_{2} / \alpha / \beta$ layer structure was investigated over the range of experimental conditions: temperature $25-1400^{\circ} \mathrm{C}$; strain rate $10^{-6}-10^{-1} \mathrm{~s}^{-1}$; oxygen content $0.11-4.4$ wt \%; grain size 5-50 $\mu \mathrm{m}$; texture longitudinal, transverse, and diagonal orientations; and microstructural state, which consists of the equiaxed $\alpha$ phase and various transformed $\beta$ acicular structures. The work-hardening and strain-rate sensitivity parameters weredetermined from the experimental results, and the tensile properties werecorrelated with oxygen concentration, oxygen distribution in the material, and microstructure. Dynamic strain-aging phenomena were observed in Zircaloy at 200,400 , and $700^{\circ} \mathrm{C}$, and superplastic deformation occurred at 850 and $1000^{\circ} \mathrm{C}$. An increase in the oxygen concentration in homogeneous Zircaloy-oxygen alloys increased the ultimate tensile strength and decreased the total strain, particularly below $\sim 900^{\circ} \mathrm{C}$. In composite specimens with the $\mathrm{Z} \mathrm{rO}_{2} / \alpha / \beta$ structure, the total oxygen content had little effect on the ultimate tensile strength below $\sim 1000^{\circ} \mathrm{C}$, but the strength increased with oxygen content at higher temperatures. Information on the effects of grain size, oxygen content, texture, and strain rate on the stress-strain behavior suggests that the dominant mechanism of superplastic deformation in $\mathrm{Zircaloy}$ near $\sim 850^{\circ} \mathrm{C}$ is grain-boundary sliding at the $\alpha-\beta$ interface with accommodation by diffusional creep, dislocation slip, and grainboundary migration. Good correlation was obtained between ductility and values of the strain-rate sensitivity parameter.
\end{abstract}

\title{
I. INT RODUCTION
}

This report consists of a compilation of Zircaloy tensile data reported over the past two years in Light-Water-Reactor Safety Research Program quarterly progress reports, ${ }^{1-8}$ along with some additional results. The information represents a portion of the mechanical-property data on Zircaloy and Zircaloy-oxygen alloys generated in a U.S. Nuclear Regulatory Commissionsponsored program in which the effect of oxygen on the uniaxial, biaxial, and impact properties of Zircaloy are being determined. 
The objective of the program is to establish a quantitative cladding embrittlement criterion applicable to postulated loss-of-coolant accident (LOCA) situations in light-water-reactors (LWR's). The mechanical-property information will be incorporated into fuel-element modeling codes that will provide a quantitative basis for evaluating cladding deformation over a wide range of LOCA and power-coolant-mismatch (PCM) conditions. Most of the reported data are for $\mathrm{Zircaloy}-4$ material. However, scoping tests conducted on $\mathrm{Z}$ ircaloy -2 material show no significant difference between the deformation behavior of the two grades of Zircaloy.

The uniaxial tensile stress-strain behavior of longitudinal and transverse texture $\mathrm{Zircaloy}-2$ and -4 specimens was investigated over the range of experimental conditions: temperature, $25-1400^{\circ} \mathrm{C}$; strain rate, $10^{-6}-10^{-1} \mathrm{~s}^{-1}$; oxygen concentration, 0.11-4.4 wt \% (both homogeneous and composite materials); grain size, 5-50 $\mathrm{m}$; microstructural state, equiaxed $\alpha$ and various transformed $\beta$ acicular microstructures. The tensile data provide information on the ductility, work-hardening rate, strain-rate sensitivity, and the relationship between the microstructure of the material (prior history) and these properties.

\section{MATERIALS, APPARATUS, AND PROCEDURES}

\section{A. Materials}

Zircaloy-2 and -4 sheet material was used to fabricate the tensile test specimens: 'T'able $I$ lists the compositions of the materials obtained from AMAX Specialty Metals and Teledyne Wah Chang along with the grain size, thickness, and heat treatment. An X-ray diffractometer scan of the Zircaloy -2 sheet indicated the expected high ( $00 l$ ) intensity in the plane of the rolled.sheet.

A 6.35-mm-thick hot-rolled and annealed Zircaloy-4 plate was also obtained from Teledyne Wah Chang. The composition of the material was practically identical to that of the $U .63 \mathrm{~b}-\mathrm{mm}-$ thick $1 \mathrm{l}-\mu \mathrm{m}$ grain-size foil: This plate was processed by the Materials Processing and Development Group of the Materials Science Division, to obtain fine grain-size ( $5-\mu \mathrm{m})$ Zircaloy-4 by the following sequence. The $6.35-\mathrm{mm}$ plate was cleaned and sheared into pieces. Each piece was cold-rolled from a 6.35- to a 4.88-mm thickness, cleaned, and vacuum annealed $\left(3 \times 10^{-3} \mathrm{~Pa}\right)$ at $700^{\circ} \mathrm{C}$ for $3.6 \mathrm{ks}$. Then the material was cold-rolled from a 4.88 - to a $2.92-\mathrm{mm}$ thickness, cleaned, and vacuum-annealed as before. A metallographic examination of the Zircaloy-4 sheet revealed an average recrystallized grain size of $20 \mu \mathrm{m}$. Variations in the amount of cold work and different combinations of annealing times and temperatures in the range of $650-750^{\circ} \mathrm{C}$ failed to produce a grain size $\lesssim L L \mathrm{~m}$.

After a suggestion by Picklesimer ${ }^{9}$ to warm-roll at $400^{\circ} \mathrm{C}$ and anneal at $550^{\circ} \mathrm{C}$, the fabrication sequence was modified to obtain a $5-\mu \mathrm{m}$ grain size. 
The $20-\mu \mathrm{m}$ grain-size sheet was warm-rolled in air at $400^{\circ} \mathrm{C}$ from a 2.92 - to a $0.635-\mathrm{mm}$ thickness in 14 passes. Approximately $10 \%$ reduction in area was achieved per pass, and the material was reheated after each pass. After hot rolling, a slight yellow-brown discoloration of the surface due to oxidation occurred; however, a heavy scale was not formed. The surface was cleaned by vapor-blasting with 400 -grit alumina' suspended in water.

TABLE I. Source and Composition of Zircaloy -2 and -4 Materials Used in Fabrication of Uniaxial

Test Specimens

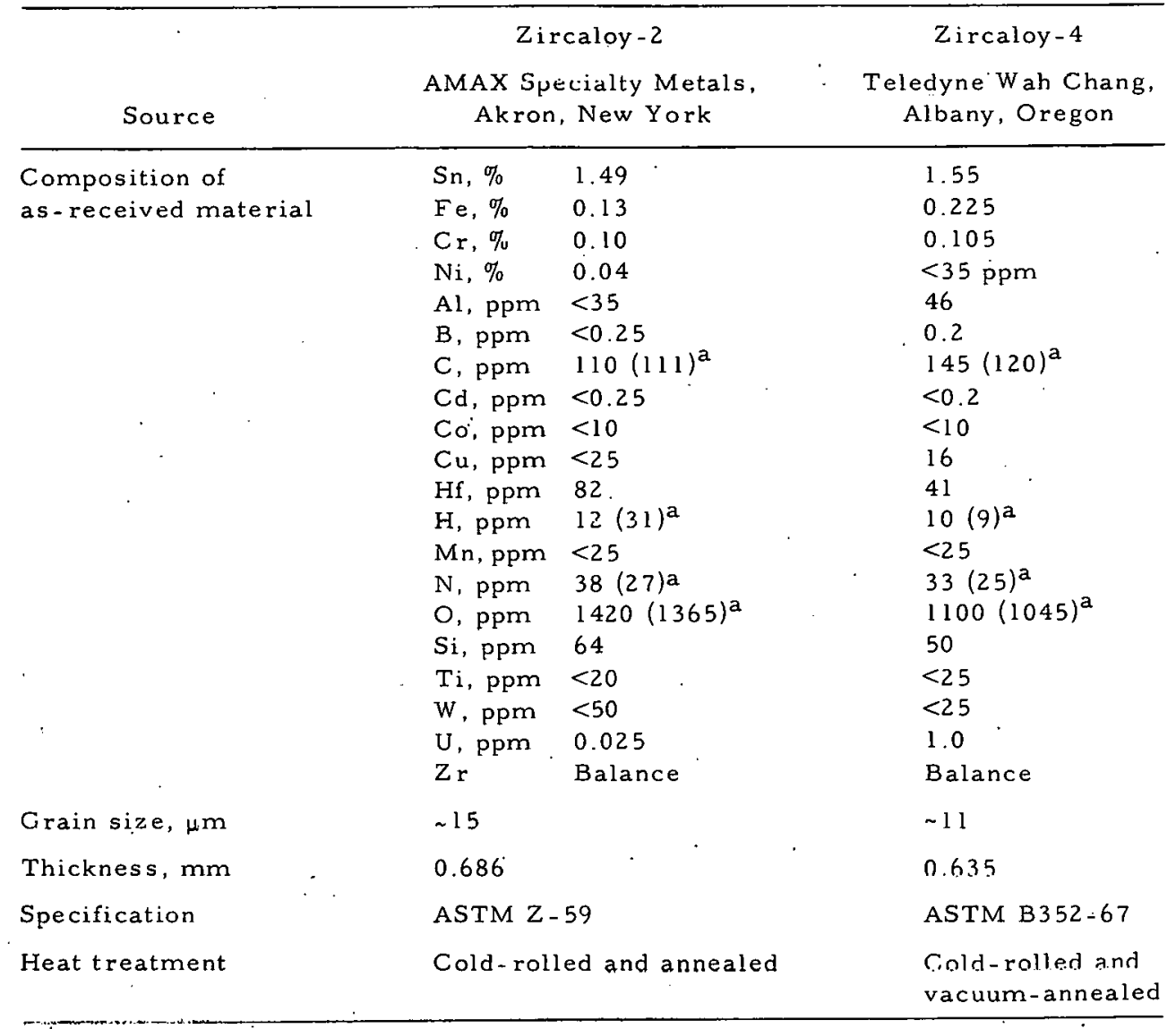

${ }^{\mathrm{a}} \mathrm{ANL}$ analysis results :

After cleaning with soap and water, the surface was polished with Scotch Bright (alumina-impregnated nylon) and rinsed with water, acetone, and alcohol. The sheets were given a final vacuum anneal $\left(3 \times 10^{-3} \mathrm{~Pa}\right)$ at $550^{\circ} \mathrm{C}$ for $1.8 \mathrm{ks}$, which resulted in an average recrystallized grain size of $\sim 5 \mu \mathrm{m}$.

B. Tensile-specimen Geometry

Uniaxial tensile specimens with gauge lengths 25.4 and $12.7 \mathrm{~mm}$ (gauge widths of 6.35 and $3.18 \mathrm{~mm}$, respectively) were fabricated from Zircaloy sheet material.according to ASTM Specification E8-69. These 
specimens had width-to-thickness ratios of 10 and 5 , respectively. All specimens had a gauge length-to-width ratio of four.

Specimens with three different orientations were used. Most of the testing was performed on specimens with a longitudinal texture in which the tensile direction coincided with the rolling direction. Transverse and diagonal texture specimens were also tested in which the tensile direction was at 90 and $45^{\circ}$ to the rolling direction, respectively. The shoulder region of each specimen was reinforced on both sides by spot-welding supporting coupons of the same material to the grip area.

\section{Oxygen Charging and Homogenization}

The high-temperature oxidation of $\mathrm{Zircaloy}$ results in the formation of a $\mathrm{ZrO}_{2}$ oxide layer on $\alpha$-phase $\mathrm{Zircaloy}$ at temperatures below the $\alpha-\beta$ transition temperature of $\sim 810^{\circ} \mathrm{C}$ and $\mathrm{Z} \mathrm{ZrO}_{2} / \alpha / \beta$ composite at ternperatures above this transition. Thus, the test-specimen production scheme essentially consists of two parts: (1) oxygen charging to a desired concentration and (2) homogenization by high-temperature annealing to eliminate both the phase boundaries and concentration gradients. A Sieverts apparatus for the purpose of oxygen charging and two high-vacuum annealing furnaces for homogenization were used.

\section{Oxygen-charging and Homogenization Furnace}

A modified Sieverts apparatus with a Marshall furnace that has a 62-mm-dia, 450-mm-long Pt-30\% Rh heating element and a $250-\mathrm{mm}$-long uniform-temperature zone was used for charging oxygen into the Zircaloy test specimens. A vacuum in the range of $1.3 \times 10^{-4} \mathrm{~Pa}$ was achieved at terriperatures up to $\sim 1300^{\circ} \mathrm{C}$ with the diffusion pump and the liquid-nitrogen trap. Thermocouples of $\mathrm{Pt}-\mathrm{Pt} 10 \% \mathrm{Rh}$ calibrated against the melting points of aluminum and copper, were used for temperature measurements and control sensing. The temperature-sensing thermocouple was placed at the outer surface of the alumina muffle tube, and a direct temperature reading was displayed on a strip-chart recurder. With a combination of a silicon-controlled restifier power supply and a Digiset null detector, temperature could be stabilized within $\pm 5^{\circ} \mathrm{C}$ up to $1200^{\circ} \mathrm{C}$. Specimens were placed inside a recrystallized, impervious alumina muffle tube, which was connected to the pumping and gashandling system by a standard tapered joint with a silicone sleeve. The Zircaloy specimens were suspended from a $1-\mathrm{mm}$-dia Pt-40\% $\mathrm{Rh}$ wire.

Two high-temperature, high-vacuum Centor furnaces for homogenization of the $\mathrm{Zircaloy}$ specimens were calibrated and operated at temperatures up to $1600^{\circ} \mathrm{C}$. Both systems have tungsten heating elements and tantalum heat shields that can operate in vacuum, inert-gas, or reducing atmospheres. Uniform temperatures were maintained over half the length of the $61-\mathrm{mm}-\mathrm{dia}, 125-\mathrm{mm}-\mathrm{long}$ and $75-\mathrm{mm}$-dia, 200-mm-long heat zones. The 
temperatures were measured with $\mathrm{Pt}-10 \% \mathrm{Rh}$ thermocouples and compared with optical-pyromete $\mathrm{r}$ and thermal-converter readings. At $1400^{\circ} \mathrm{C}$, the temperature could be maintained constant within $\pm 10^{\circ} \mathrm{C}$ for up to $108 \mathrm{ks}$. Rapid heating and cooling of the specimens could be achieved; however, it took $\sim 0.9 \mathrm{ks}$ before the power level and temperature stabilized at $1400^{\circ} \mathrm{C}$ in the automatic control mode. Temperature readings were recorded on a stripchart recorder.

\section{Oxidation Procedure}

The mechanical-property test specimens were degreased in toluene and acetone, dried, and then weighed on a microbalance. Six to ten specimens were placed inside the alumina muffle tube and the system was evacuated to $1.3 \times 1.0^{-4} \mathrm{~Pa}$. The specimens were heated to the charging temperatures given in Table II, and a measured quantity of a $1: 3$ oxygen-helium gas mixture was admitted to the reaction tube through a needle valve. The pressure was increased from 1.3 Pa at the onset of the reaction to $260 \mathrm{~Pa}$ in $\sim 30 \mathrm{~s}$ to prevent an appreciable temperature increase in the specimens. After this initial period, the gas pressure was increased to $6.5 \times 10^{4} \mathrm{~Pa}$, i.e., an oxygen partial pressure of $1.62 \times 10^{4} \mathrm{~Pa}$. In a few instances when the gas admission rate was too high, an appreciable temperature increase was recorded for $\sim 30 \mathrm{~s}$; however, autoignition did not occur.

TABLE II. Summary of Oxidation and Homogenization Conditions for Zircaloy Test Specimens ${ }^{a}$

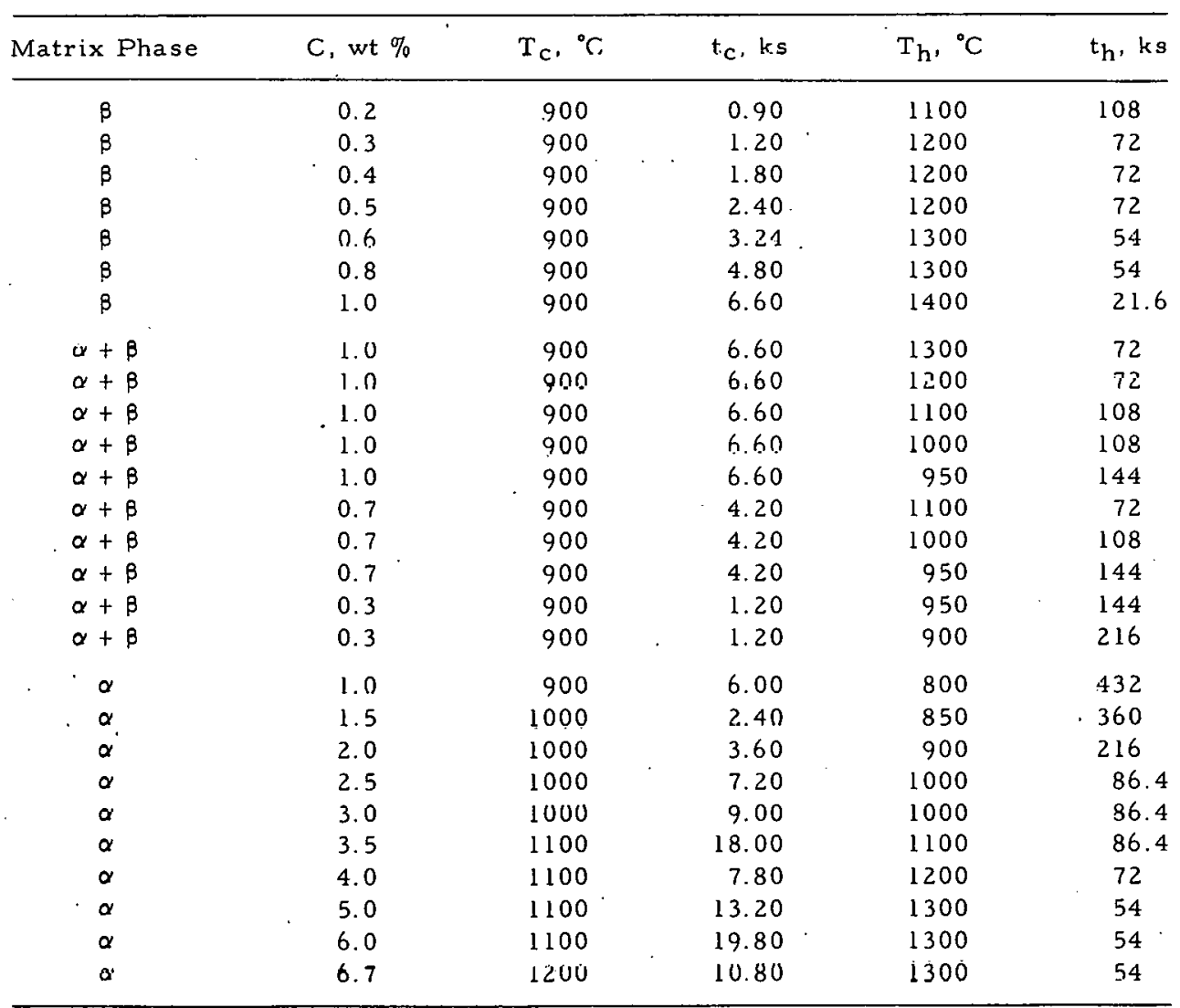

${ }^{a} \mathrm{C}=$ oxygen concentration; $\mathrm{T}_{\dot{C}}=$ oxygen-charging temperature; ${ }_{{ }_{c}}=$ oxygencharging time; $\mathrm{T}_{\mathrm{h}}=$ homogenization temperature; and $\mathrm{t}_{\mathrm{h}}=$ homogenization time. 
After the desired period of oxygen charging, the specimens were cooled and the weight gain was determined. The variation of weight gains between the specimens in the same group was within $\pm 4 \%$. No reaction between the $\mathrm{Pt}-40 \% \mathrm{Rh}$ specimen suspension wires and the $\mathrm{Zircaloy}$ was observed at 900 or $1000^{\circ} \mathrm{C}$.

\section{Homogenization Procedure}

The oxygen-charged specimens were sealed in a 56-mm-dia, 125-mm-long tantalum capsule by electron-beam welding in a $1.3 \times 10^{-3}-\mathrm{Pa}$ vacuum and then annealed in either of the Centor furnaces. The tantalum capsule acts as an effective getter in removing any reactive impurities in the residual vacuum inside the capsule. Specimens that were oxidized at $1000^{\circ} \mathrm{C}$ for $1.8 \mathrm{ks}$ to an average oxygen concentration of 3.6 . wt \% and then homogenizcd for $90 \mathrm{ks}$ at $1000^{\circ} \mathrm{C}$ showed a weight gain corresponding to only $0.012 \mathrm{wt} \%$ oxygen. 'l'he $\mathrm{Yt}-40 \%$ Rh wire used to suopond the Lirsaloy sperimens was found to be satisfactory at temperatures up to $1200^{\circ} \mathrm{C}$.

At $1400^{\circ} \mathrm{C}$ and above, the wire forms a low-melting eutectic with Zircaloy and melts during the homogenization anneal. The Pt-10\% Rh wire was satisfactory for temperatures up to $1400^{\circ} \mathrm{C}$ and $108 \mathrm{ks}$ of annealing. Above $1400^{\circ} \mathrm{C}$, a significant reaction occurs with either Zircaloy or tantalum and platinum, $\mathrm{Pt}-10 \% \mathrm{Rh}, \mathrm{Pt}-40 \% \mathrm{Rh}, \mathrm{Mo}$, and $\mathrm{W}-\mathrm{Re}$ alloys. However, rhenium was found to be satisfactory up to $25.2 \mathrm{ks}$ at $1500^{\circ} \mathrm{C}$. In view of this, homogenization at $1400^{\circ} \mathrm{C}$ was limited to the production of $\beta$-phase $\mathrm{Zircaloy}$ with 1 wt $\%$ oxygen, which required the high temperature because of phaseequilibrium considerations.

According to the phasc diagram of Savitakii et. al.. ${ }^{10} \mathrm{Zr}-\mathrm{Re}$ forms a eutectic at $\sim 26$ wt \% Z r compusilion, which mclts at . $16004:$. From nur information obtained by homógenizatiun lédinents und lic sube oqusnt harr. ness profile measurements, a rather conservative estimate of required annealing temperature and time is given in Table II for each set of conditions.

D. Mechanical. Testing Facility

Two Instron machines (Models 'l'l'LML and 1123) wert: used fur lle merhaniral testing. These machines were equipped with high-temperature/ high-vacuum furnaces with split tungsten heating elements that can operate at temperatures $>1400^{\circ} \mathrm{C}$ at a vacuum $<1 \times 10^{-3} \mathrm{~Pa}$. The heating and cooling rates of the furnace were controlled by a Data-Trak programmer. The loadelongation data were converted to true-stress/true-strain data by a computer program that made use of the constant volume approximation. Tensile tests at variable speeds were conducted to determine the slrain-rate sensitivity parameter. 
E. Metallography and Specimen Characterization

After oxygen charging or the homogenization treatment, it was necessary to characterize the specimen in terms of both the phase-boundary locations and the oxygen-concentration gradient. Oxidized specimens with $\mathrm{ZrO}_{2} / \alpha$ and $\alpha / \beta$ boundaries were sectioned by a carborundum wheel or an electron-beam technique, cold-mounted, polished in a vibratory polisher, and etched in a $50 \%$ distilled $\mathrm{H}_{2} \mathrm{O}: 45 \% \mathrm{HNO}_{3}: 5 \% \mathrm{HF}$ solution to observe the phase boundaries and grain structure. Anodization of the specimens in a solution containing $0.06 \mathrm{~m}^{3}$ absolute ethanol:0.035 $\mathrm{m}^{3} \mathrm{H}_{2} \mathrm{O}: 0.02 \mathrm{~m}^{3}$ glycerine:0.01 $\mathrm{m}^{3}$ lactic acid $(85 \%): 0.005 \mathrm{~m}^{3}$ phosphoric acid $(85 \%): 0.02 \mathrm{~kg}$ citric acid was also used to develop the structure for metallographic examination. The specimen color and the current drop provided convenient criteria for adequate anodization: ${ }^{11-13}$ In most cases, polarized light was required to obtain satisfactory contrast. The optimum procedures for specimen preparation, which involve chemical etching and/or anodizing, were highly dependent upon the oxygen concentration in the alloy, the phase distributions, and whether the specimen was Zircaloy -2 or -4 . Similar metallographic techniques were used to examine microstructures of deformed samples.

To determine the presence of oxygen-concentration gradients in the specimens, microhardness measurements were made with a Leitz hardness tester. The microhardness was found to be independent of load, in the range of $0.025-0.5 \mathrm{~kg}$, and the Vickers hardness data were judged to be more reliable than the Knoop measurements. Both were calibrated against standard hardness materials. Hardness measurements in the $\alpha$ phase in the immediate vicinity of the $\mathrm{ZrO}_{2} / \alpha$ phase boundary frequently produced cracks that resulted in non reproducible hardness values. For the homogenized specimens, the absence of phase boundaries was verified by metallographic observation and the hardness profile across the thickness.

F. Work-hardening Analysis

The work-hardening analysis of the Zircaloy tensile data was conducted according to the C russard-Jaoul method, ${ }^{14-16}$ which is based on the Ludwik equation, ${ }^{17}$

$$
\sigma=\sigma_{0}+k \epsilon^{n}
$$

where $\sigma$ is the true stress, $\epsilon$ is the true strain, $n$ is the work-hardening exponent, and $k$ and $\sigma_{0}$ are constants introduced to obtain a best fit with the experimental data. Differentiating $\mathrm{Eq}$. 1 with respect to strain and taking the logarithm of both sides, we obtain

$$
\log \frac{d \sigma}{d \varepsilon}=\log (k n)+(n-1) \log \varepsilon .
$$


Therefore, when $\log (\mathrm{d} \sigma / \mathrm{d} \varepsilon)$ is plotted as a function of $\log \varepsilon$, the slope of the curve is $n-1$, and the intercept on the log (slope) axis is log(kn). To obtain a better fit between Eq. 1 and the experimental stress-strain curve, the stress-strain curve can be divided into different deformation stages ${ }^{18}$ so that each stage has a different set of parameters $\sigma_{0}, k$, and $n$. The stages are numbered so that stage 2 generally represents a major portion of the stressstrain curve. A least-squares straight-line fit was used to calculate the slope (and therefore $n$ ) and the intercept for each stage. Since Eq. I does not take into account the change in strain rate during a tensile test, the CrussardJaoul work-hardening analysis can be applied only to the uniform deformation region (i.e., before the onset of necking).

\section{G. Strain-rate-sensitivity Determination}

The strain-rate-sensitivity parameter, $m$, is defined by

$$
\left(\sigma_{2} / \sigma_{1}\right)=\left(\dot{\varepsilon}_{2} / \dot{\varepsilon}_{1}\right)^{\mathrm{m}} \text {, }
$$

where $\sigma_{1}$ and $\sigma_{2}$ are the flow stresses at strain rates $\dot{\epsilon}_{1}$ and $\dot{\varepsilon}_{2}$, respectively. The strain-rate sensitivity $m$ was determined from constant-temperature differential-crosshead velocity tests where a load change assuciated with a crosshead velocity change was measured at constant strain.

\section{MECHANICAL PROPERTIES OF ZIRCALOY - 2}

A. As-received Zircāloy-2

\section{Slréss-Strain Curveo}

Figures 1 and 2 show the engineering stress-strain curves for Zircaloy-2 s.pecimens fractured at the strain rate of $3.3 \times 10^{-3} \mathrm{~s}^{-1}$. In this

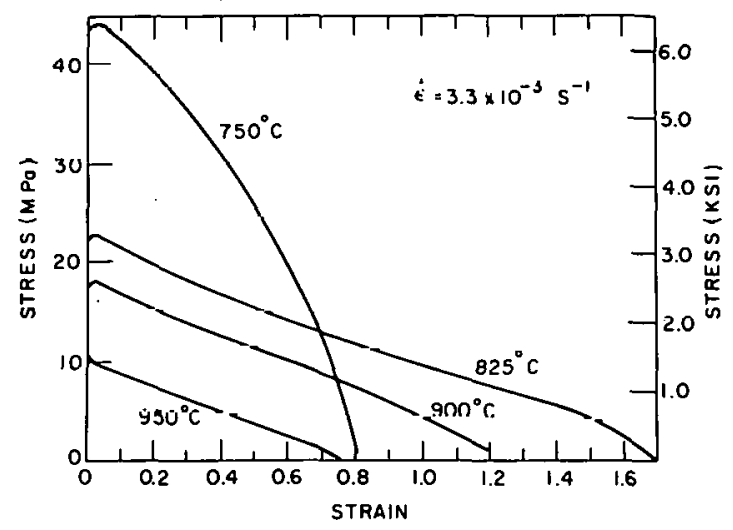

Fig. 1. Engineering-stress/Engineering-strain Curves for As-received Zircaloy-2 Specimens Deformed at Temperatures between 750 and $950^{\circ} \mathrm{C}$. Neg. No. MSD-60897.

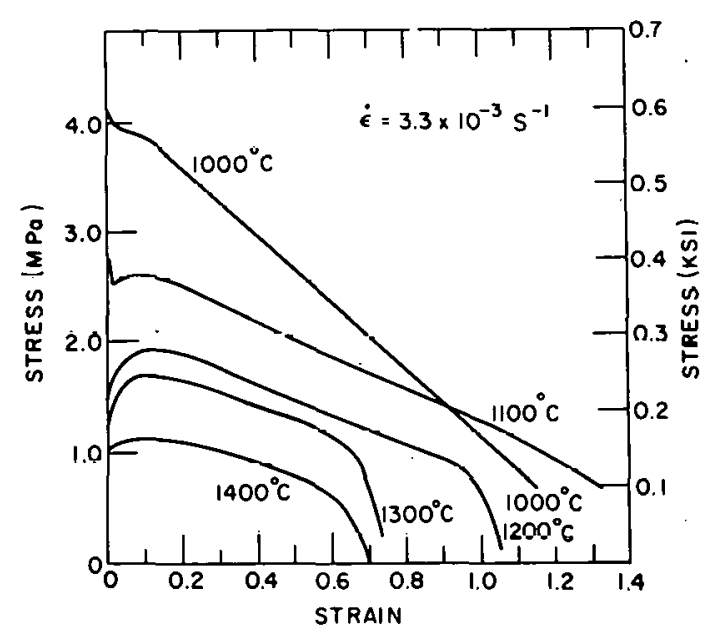

Fig. 2. Engineering-stress/Engineering-strain Curves for As-received Zircaloy-2 Specimens Deformed at Temperatures between 1000 and $1400^{\circ} \mathrm{C}$. Neg. No. MSD-60895. 
report, the engineering stress is based on the original cross-sectional area, and the engineering strain is calculated from the original gauge length, i.e., the total strain is defined as $\left(l-l_{0}\right) / l_{0}$, where $l_{0}$ is the initial gauge length of the specimen and $\ell$ is the specimen gauge length at fracture. The maximum load point (corresponding to the uniform strain) on all these curves in Figs. 1 and 2 occurred at a strain less than 0.1. Therefore, true-stress and true-strain calculations beyond the uniform strain require a necking correction to account for the triaxial state of stress. To apply the necking correction, neck-profile measurements during the test are necessary. Such measurements were not possible with the present cquipment because of the high-temperature/highvacuum environmental chamber. The measurement of the fracture area, to calculate the true fracture stress, also had a number of practical difficulties for test temperatures above $1000^{\circ} \mathrm{C}$ that resulted from excessive grain growth. These include the unevenness of the specimen surface, which made it difficult to measure the thickness, double-neck formation, and the small specimen thickness at the point of fracture.

A linear-intercept grain-size estimation in the gauge length of the fractured specimens revealed that, up to $1000^{\circ} \mathrm{C}$, the grain size was close to that of as-received material, i.e., $15 \mu \mathrm{m}$. At higher temperatures, grain size during deformation was estimated from the prior $\beta$ grain size, which was deduced from the room-temperature transformed $\beta$ structure. On a number of occasions, it was difficult to estimate prior $\beta$-grain size from the metallographically polished samples because of the acicular structure obtained during the $\beta \rightarrow \alpha^{\prime}$ transformation. Thermal etching of the specimens during deformation in the high-temperature/high-vacuum environment provided a means for estimating the prior $\beta$-grain size. The cstimates from the shoulder region of the samples deformed at $\dot{\varepsilon}=3.3 \times 10^{-3} \mathrm{~s}^{-1}$ are as follows: $1100^{\circ} \mathrm{C}$ $(440 \mu \mathrm{m}), 1200^{\circ} \mathrm{C}(600 \mu \mathrm{m}), 1300^{\circ} \mathrm{C}(750 \mu \mathrm{m})$, and $1400^{\circ} \mathrm{C}(850 \mu \mathrm{m})$. Thus, the stress-strain curves in Fig. 2 correspond to different grain sizes. Grain coarsening during simulated LOCA conditions has been observed in Zircaloy $-2 .^{19}$

Figure 3 is a plot of the temperature dependence of the $0.2 \%$ offset yield stress and ultimate-tensile sirength. Both the yield stress and the ultimate tensile strength decrease continuously with an increase in temperature. Figure 4 shows the variations of the uniform strain, total strain, and necking strain (from the maximum load point to the fracture point) with temperature. Note that below $1100^{\circ} \mathrm{C}$, the uniform elongation is almost zero and that necking elongation almost completely accounts for the total elongation. Another significant feature of $\mathrm{Fig.} 4$ is the minirnum in the necking strain and total strain at $950^{\circ} \mathrm{C}$.

The elongation peaks near 850 and $1100^{\circ} \mathrm{C}$ are manifestations of superplasticity. This point will be discussed in detail in subsequent sections. 


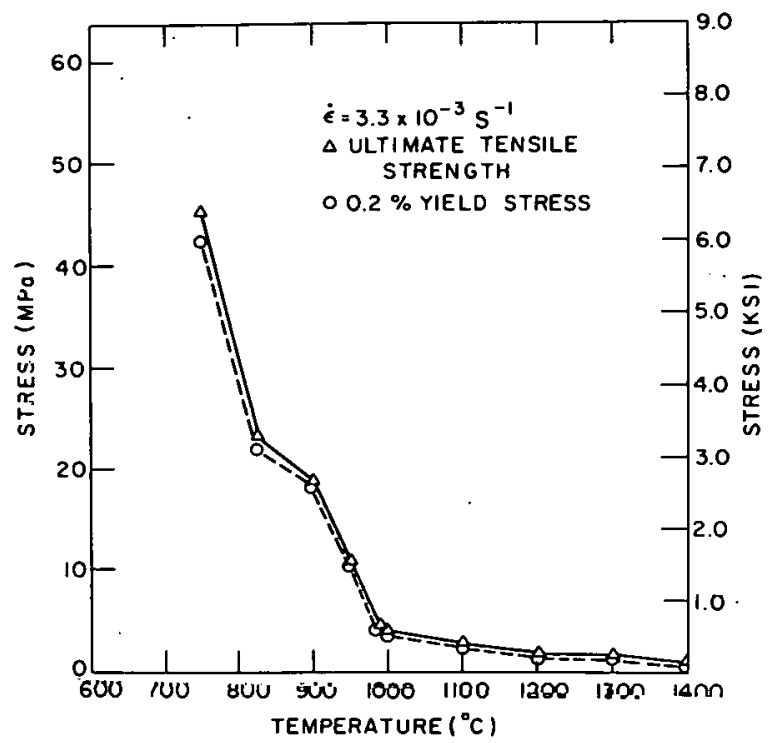

Fig. 3. Effect of Temperature on $0.2 \%$ Yield Stress and Ultimate Tensile Strength of As-received Zircaloy-2. Neg. No. MSD-60902.

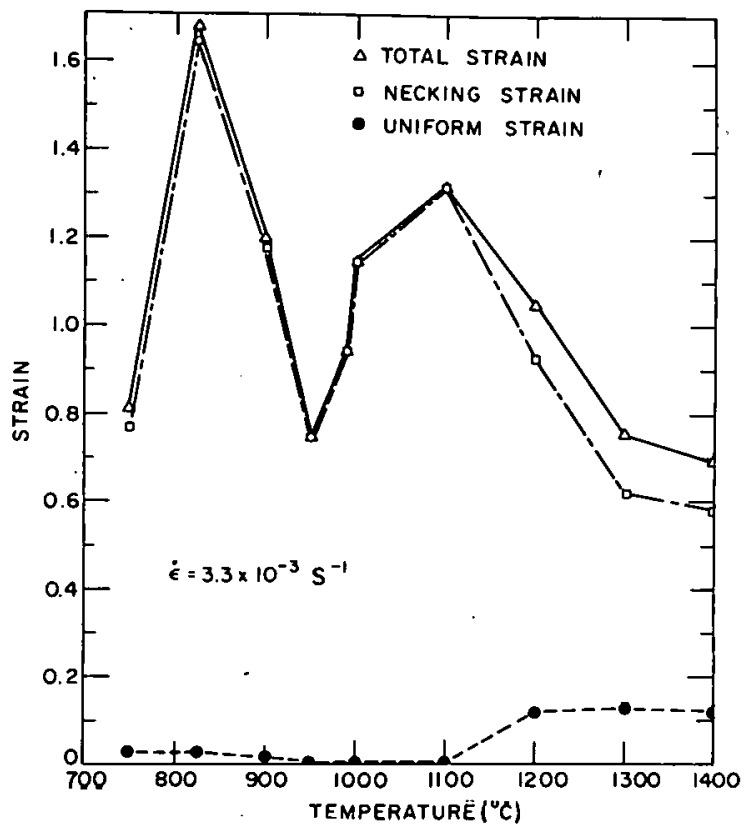

Fig. 4. Effect of Deformation Temperature on Uniform, Necking, and Total Strains for Zircaloy-2 Specimens. Neg. No. MSD-60901.

\section{Strain-rate Sensitivity}

Figure 5 shows the effect of strain on the strain-rate sensitivity of $\mathrm{Zircaloy-2.} \mathrm{Note} \mathrm{that} \mathrm{the} \mathrm{strain-rate} \mathrm{sensitivity} \mathrm{decreases} \mathrm{with} \mathrm{strain} \mathrm{at}$ large strains in all cases, except at 800 and $900^{\circ} \mathrm{C}$, where superplastic deformations are observed. Once localized deformation due to necking starts, the strain-rate cycling technique gives $m$ values at a higher starting strain rate. For this reason, the measurements reported in Fig. 5 were limited to $\epsilon=0.20$. Between 700 and $900^{\circ} \mathrm{C}$, however, necking was not easily detected in the profile of the specimens deformed to a considerable stiain beyond the maximum load point on the load-elongation curve. In these cases, therefore, the strain-rate cycling was continued to higher strains. The results are shown in Fig. 6. Note that at 850 and $900^{\circ} \mathrm{C}$, where superplastic deformations are observed, the strain-rate sensitivity continues to increace with strain at large values of atrain. The rate of increase of $\mathrm{m}$ with strain $(\partial \mathrm{m} / \partial \epsilon)$, is less significant at 700 and $800^{\circ} \mathrm{C}$. Figure 7 shows the effect of strain rate and strain oir the $900^{\circ} \mathrm{C}$ strain-rate sensitivity of $Z$ ircaloy-2. At slower strain rates, the value of $\mathrm{m}$ is higher and more sensitive to strain; this probably explains the larger superplastic deformations at slower strain rates.

The temperature dependence of the strain-rate sensitivity of Zircaloy- 2 is plotted in Fig. 8. Normally, $m$ increases as the temperature increases; however, at high temperature, grain growth tends to decrease $\mathrm{m}$. Excessive grain growth is probably responsible for the poorly defined minimum near. $1100^{\circ} \mathrm{C}$ and the decrease in $\mathrm{m}$ above $1200^{\circ} \mathrm{C}$. Figure 8 also shows $\mathrm{Zircaloy}-4$ data that extibit a larger variation with temperature and a maximus 
near $900^{\circ} \mathrm{C}$. Results presented in later sections show that superplastic elongations are observed in Zircaloy -4 deformation near $900^{\circ} \mathrm{C}$. Also, above $1200^{\circ} \mathrm{C}$, the $\mathrm{Zircaloy}-4$ strain-rate sensitivity is higher than that of Zircaloy -2 . This is probably due to the higher oxygen concentration in $\mathrm{Zircaloy}-2(0.14$ wt \%) than in Zircaloy-4 (0.11 wt \%).

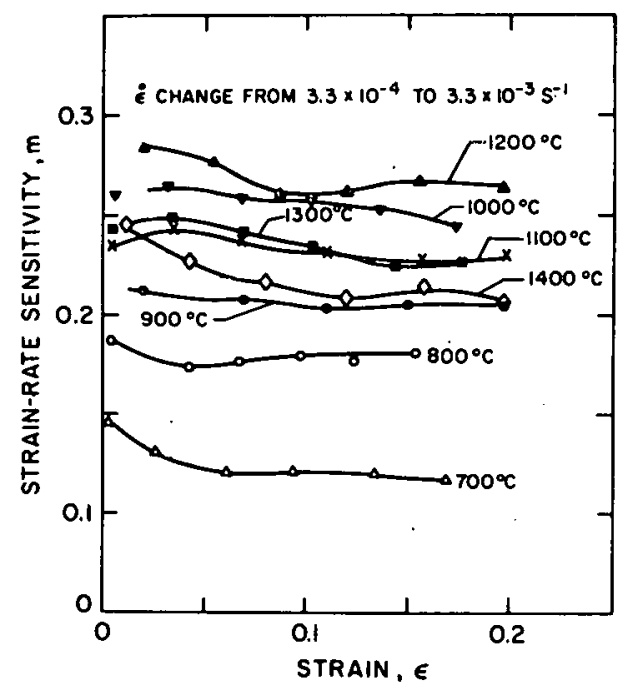

Fig. 5. Strain Dependence of Strain-rate Sensitivity of Zircaloy-2 at Temperatures between 700 and $1400^{\circ} \mathrm{C}$ for Strains below 0.2 . Neg. No. MSD-61490.

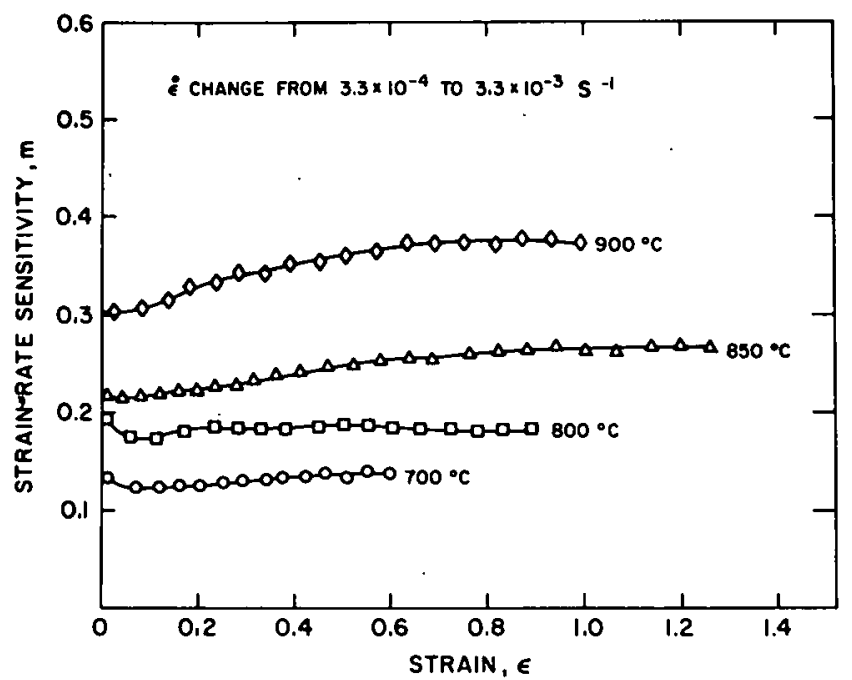

Fig. 6. Strain Dependence of Strain-rate Sensitivity of Zircaloy-2 at 700 . 800,850 , and $900^{\circ} \mathrm{C}$ for Strains to $\sim 1.3$. Neg. No. MSD-61487.

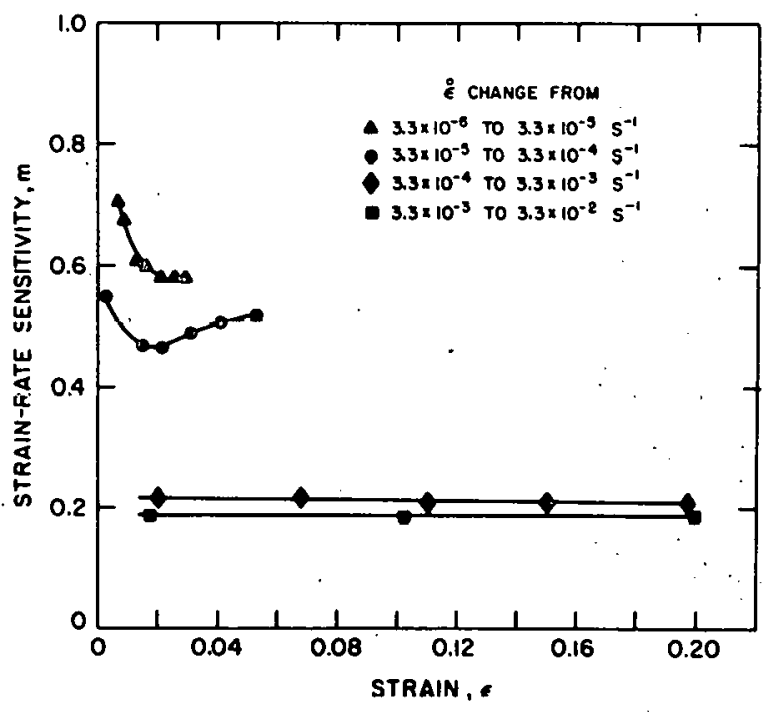

Fig. 7. Effect of Strain Rate on Strain Dependence of Strain-rate Sensitivity of Zircaloy-2 at $900^{\circ} \mathrm{C}$. Neg. No. MSD-61496:

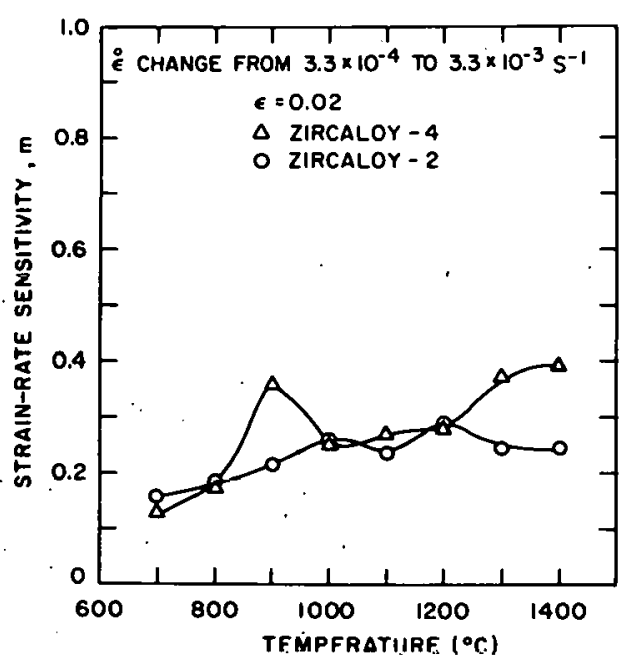

Fig. 8. Temperature Dependence of Strain-rate Sensitivity of Zircaloy-2 and -4 Specimens. Neg. No. MSD-61502. 


\section{Work-hardening Analysis}

Figure 9 shows plots of log(slope) versus $\log$ (strain) for Zircaloy-2 specimens deformed at $900,1100,1200$, and $1400^{\circ} \mathrm{C}$. A portion of each plot can be approximated by a straight. line that designates a stage.

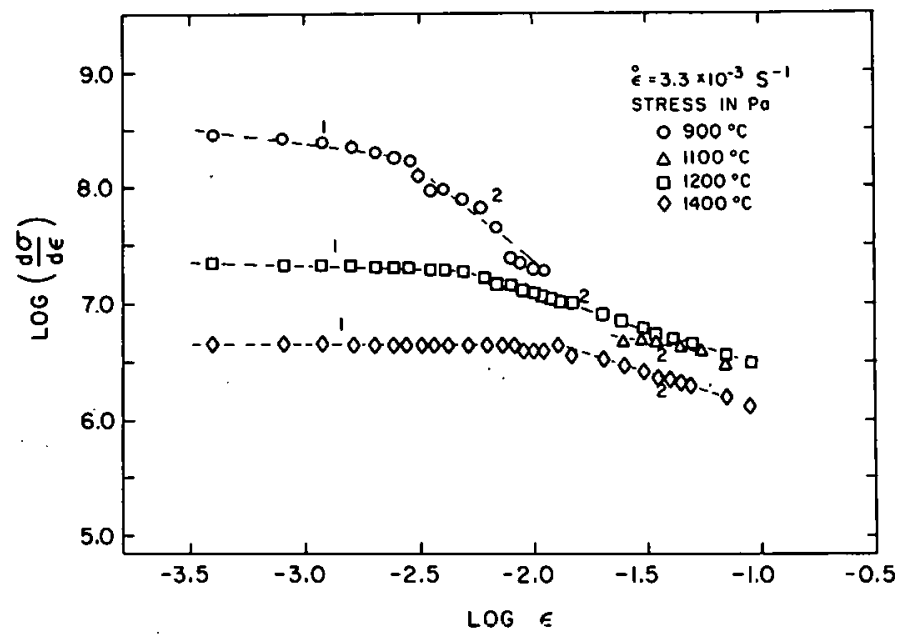

Fig. 9

Crussard-Jaoul Plots for Zircaloy-2 Specimens Deformed at 900, 1100, 1200, and $1400^{\circ} \mathrm{C}$. Neg. No. MSD-61488.

Table III lists the results of the analysis, and Fig. 10 is a plot of a portion of these data. Note that in Fig: 10, the work-hardening exponent assumes negative values and a minimum in the temperature interval $\sim 800$ $1000^{\circ} \mathrm{C}$. This tendency is greater at the lower strain rate. The variation of $k$ with temperature is similar to that of $n$.

A negative value of $n$ (or $k$ ) implies a rapid decrease in the slope of the stress-strain curve with an increase in strain. The processes during deformation that can lead to a negative value of $n$ are: dynamic recovery, dynamic recrystallization, phase transformation, grain-boundary migration, and grain-boundary sliding (intergranular deformation). The $\alpha \rightarrow \beta$ phase

Fig. 10

Temperature Dependence of Work-hardening Exponent Obtained from Zircaloy-2 Tensile Data. ANL Neg. No. 306-77-65 Rev. 1.

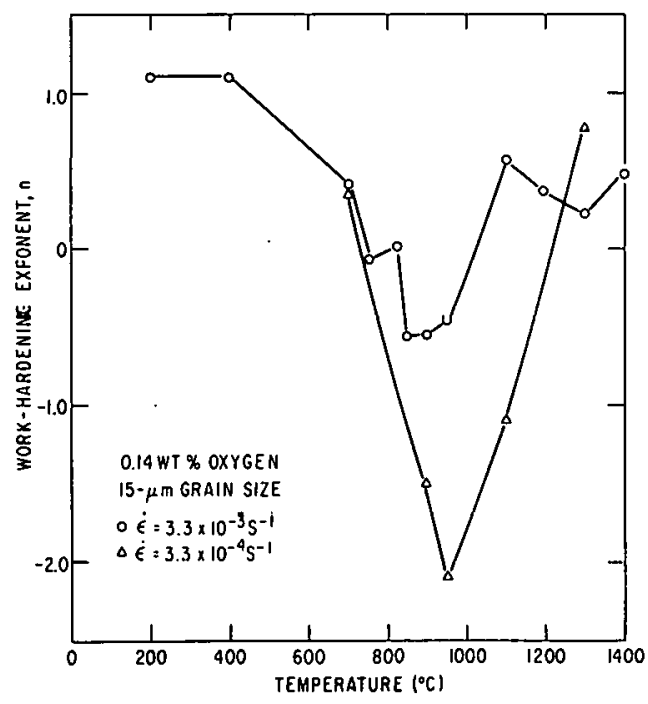


TABLE III. Least-squares Work-hardening Constants for Deformation Stages of As-received Longitudinal Zircaloy-2 Specimens from Crussard-Jaoul Analysis

\begin{tabular}{|c|c|c|c|c|c|c|}
\hline $\begin{array}{l}\text { Strain } \\
\text { Rate, } \\
\dot{\epsilon}, \mathrm{s}^{-1}\end{array}$ & $\begin{array}{l}\text { Temp, } \\
{ }^{\circ} \mathrm{C}\end{array}$ & $\begin{array}{l}\text { Stage } \\
\text { Number }\end{array}$ & $\begin{array}{c}\text { Strain } \\
\text { Interval }\end{array}$ & $\mathrm{n}$ & $\mathrm{k}, \mathrm{Pa}$ & $\begin{array}{c}\text { Average } \\
\sigma_{0}, \mathrm{~Pa}\end{array}$ \\
\hline \multirow[t]{5}{*}{$3.3 \times 10^{-4}$} & 700 & 2 & $0.0028-0.035$ & 0.35 & $3.1 \times 10^{7}$ & $3.5 \times 10^{7}$ \\
\hline & 900 & $\begin{array}{l}1 \\
2\end{array}$ & $\begin{array}{r}0.0004-0.004 \\
0.005-0.012\end{array}$ & $\begin{array}{r}0.70 \\
-1.50\end{array}$ & $\begin{array}{r}7.2 \times 10^{7} \\
-1.9 \times 10^{2}\end{array}$ & $\begin{array}{l}1.2 \times 10^{7} \\
1.4 \times 10^{7}\end{array}$ \\
\hline & 950 & $\begin{array}{l}1 \\
2\end{array}$ & $\begin{array}{l}0.0004-0.0024 \\
0.0028-0.006\end{array}$ & $\begin{array}{l}-0.18 \\
-2.10\end{array}$ & $\begin{array}{l}-7.0 \times 10^{5} \\
-7.0 \times 10^{-1}\end{array}$ & $\begin{array}{l}7.9 \times 10^{6} \\
6.0 \times 10^{6}\end{array}$ \\
\hline & 1100 & $\begin{array}{l}1 \\
2\end{array}$ & $\begin{array}{r}0.0004-0.012 \\
0.012-0.014\end{array}$ & $\begin{array}{r}0.73 \\
-1.10\end{array}$ & $\begin{array}{r}1.6 \times 10^{7} \\
-2.1 \times 10^{3}\end{array}$ & $\begin{array}{l}5.6 \times 10^{5} \\
1.5 \times 10^{6}\end{array}$ \\
\hline & 1300 & $\begin{array}{l}1 \\
2 \\
3\end{array}$ & $\begin{array}{c}0.0004-0.0028 \\
0.0032-0.014 \\
0.014-0.070\end{array}$ & $\begin{array}{l}1.03 \\
0.17 \\
0.77\end{array}$ & $\begin{array}{l}8.5 \times 10^{6} \\
3.7 \times 10^{5} \\
8.0 \times 10^{5}\end{array}$ & $\begin{array}{l}7.8 \times 10^{5} \\
6.7 \times 10^{5} \\
8.2 \times 10^{5}\end{array}$ \\
\hline \multirow[t]{12}{*}{$3.3 \times 10^{-3}$} & 200 & $\begin{array}{l}1 \\
2 \\
3\end{array}$ & $\begin{array}{c}0.0004-0.0032 \\
0.0036-0.03 \\
0.035-0.09\end{array}$ & $\begin{array}{r}-1.10 \\
1.10 \\
-0.14\end{array}$ & $\begin{array}{r}-4.4 \times 10^{3} \\
1.3 \times 10^{9} \\
-1.4 \times 10^{8}\end{array}$ & $\begin{array}{l}2.3 \times 10^{8} \\
2.3 \times 10^{8} \\
4.9 \times 10^{8}\end{array}$ \\
\hline & 400 & $\begin{array}{l}1 \\
2 \\
3\end{array}$ & $\begin{array}{c}0.0004-0.0024 \\
0.0028-0.014 \\
0.014-0.13\end{array}$ & $\begin{array}{r}-0.77 \\
1.10 \\
0.03\end{array}$ & $\begin{array}{r}-4.4 \times 10^{4} \\
2.2 \times 10^{9} \\
8.5 \times 10^{9}\end{array}$ & $\begin{array}{r}1.1 \times 10^{8} \\
1.1 \times 10^{8} \\
-8.3 \times 10^{9}\end{array}$ \\
\hline & 700 & 2 & $0.007-0.05$ & 0.41 & $3.1 \times 10^{7}$ & $4.8 \times 10^{7}$ \\
\hline & 750 & 2 & $0.0004-0.03$ & -0.06 & $-1.9 \times 10^{7}$ & $6.9 \times 10^{7}$ \\
\hline & 825 & 2 & $0.0004-0.02$ & 0.01 & $9.4 \times 10^{7}$ & $-6.8 \times 10^{7}$ \\
\hline & 850 & $\begin{array}{l}1 \\
2\end{array}$ & $\begin{array}{l}0.0004-0.0028 \\
0.0032-0.025\end{array}$ & $\begin{array}{r}0.50 \\
-0.55\end{array}$ & $\begin{array}{r}1.1 \times 10^{8} \\
-1.7 \times 10^{5}\end{array}$ & $\begin{array}{l}1.3 \times 10^{7} \\
2.4 \times 10^{7}\end{array}$ \\
\hline & 900 & $\begin{array}{l}1 \\
2\end{array}$ & $\begin{array}{l}0.0004-0.0024 \\
0.0024-0.011\end{array}$ & $\begin{array}{r}0.77 \\
-0.54\end{array}$ & $\begin{array}{r}6.3 \times 10^{7} \\
-3.3 \times 10^{4}\end{array}$ & $\begin{array}{l}1.8 \times 10^{7} \\
1.9 \times 10^{7}\end{array}$ \\
\hline & 950 & 2 & $0.0004-0.002$ & -0.46 & $-1.7 \times 10^{4}$ & $1.1 \times 10^{7}$ \\
\hline & 1100 & 2 & $0.025-0.07$ & 0.56 & $1.9 \times 10^{6}$ & $2.4 \times 10^{6}$ \\
\hline & 1200 & $\begin{array}{l}1 \\
2\end{array}$ & $\begin{array}{c}0.0004-0.004 \\
0.004-0.11\end{array}$ & $\begin{array}{l}0.92 \\
0.36\end{array}$ & $\begin{array}{l}1.3 \times 10^{7} \\
1.8 \times 10^{6}\end{array}$ & $\begin{array}{l}1.6 \times 10^{6} \\
1.4 \times 10^{6}\end{array}$ \\
\hline & 1300 & $\begin{array}{l}1 \\
2\end{array}$ & $\begin{array}{c}0.0004-0.014 \\
0.014-0.11\end{array}$ & $\begin{array}{l}0.88 \\
0.23\end{array}$ & $\begin{array}{l}8.2 \times 10^{6} \\
2.1 \times 10^{6}\end{array}$ & $\begin{array}{l}1.5 \times 10^{6} \\
9.3 \times 10^{5}\end{array}$ \\
\hline & 1400 & $\begin{array}{r}1 \\
2\end{array}$ & $\begin{array}{c}0.0004-0.013 \\
0.013-0.09\end{array}$ & $\begin{array}{l}1.00 \\
0.48\end{array}$ & $\begin{array}{l}4.3 \times 10^{6} \\
8.8 \times 10^{5}\end{array}$ & $\begin{array}{l}1.1 \times 10^{6} \\
1.0 \times 10^{6}\end{array}$ \\
\hline
\end{tabular}

transformation occurs extremely rapidly; therefore it is expected that the transformation is complete within the $0.6 \mathrm{ks}$ hold period at the test temperature prior to deformation. Phase transformation is not likely to affect the work-hardening rate.

The remaining four factors influence the work-hardening rate to a different extent depending on the strain-rate and deformation temperature. Grain-boundary sliding is significant at higher temperatures $\left(\gtrsim 800^{\circ} \mathrm{C}\right)$ and lower strain rates $\left(\leqslant 10^{-3} \mathrm{~s}^{-1}\right)$. The substantial grain growth during deformation at temperatures $>1000^{\circ} \mathrm{C}$ increases the work-hardening rate, since grain growth decreases the extent of grain-boundary sliding and grain-boundary 
migration. Dynamic recovery probably occurs at all temperatures, and its extent increases as the temperature increases. Recrystallization of the $\alpha$ phase occurs above $725^{\circ} \mathrm{C}$.

\section{Superplasticity}

Several scoping tests have been made at initial strain rates between $10^{-4}$ and $10^{-5} \mathrm{~s}^{-1}$. At $900^{\circ} \mathrm{C}$, the Zircaloy-2 specimens exhibited superplastic behavior characterized by a small (practically zero) uniform elongation, quite large necking elongation (and therefore a large total elongation), zero or negative work-hardening exponents, and a large value $(>0.2)$ for the strain-rate

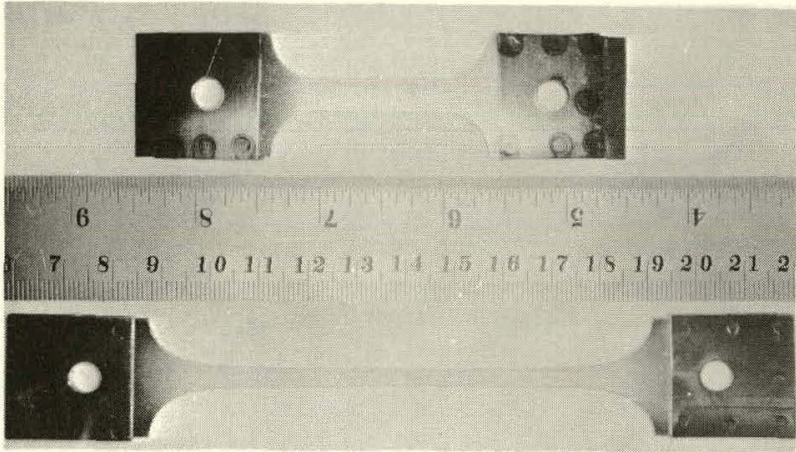

Fig. 11

Comparison between a Zircaloy-2 Specimen Strained under Superplastic Conditions (i.e , $900^{\circ} \mathrm{C}, \epsilon=6.6 \times 10^{-5} \mathrm{~s}^{-1}$ ) and an Undeformed Specimen. Neg. No. MSD-60891. sensitivity parameter. The macrophotograph in Fig. 11 compares a Zircaloy-2 specimen deformed at $900^{\circ} \mathrm{C}$ $\left(\dot{\epsilon}=6.6 \times 10^{-5} \mathrm{~s}^{-1}\right)$ and an undeformed specimen. Even after deformation to a strain of $220 \%$, no visible concentrated neck occurs in the gauge section of the specimen. A considerable strain in the width and thickness directions is also present. As seen in Fig. 11 (deformed specimen), the strain in the width direction is $\sim 50 \%$ in the center of the gauge length. At the same point the measured strain in the thickness direction was $\sim 40 \%$. Similar behavior was observed at a strain rate of $3.3 \mathrm{x}$ $10^{-4} \mathrm{~s}^{-1}$.

The factors responsible for this superplastic behavior are probably the tine grain size and two-phase structure. As stated earlier, grain coarsening occurs above $1000^{\circ} \mathrm{C}$. At $900^{\circ} \mathrm{C}$, on the other hand, some grain-size refinement occurs during deformation. For example, in the gauge section of the specimen deformed at $900^{\circ} \mathrm{C}$, the average grain size was $\sim 7 \mathrm{~m}$. The undeformed shoulder region of the same specimen had a grain size of $15 \mu \mathrm{m}$, the same as the as-received material. A similar effect was observed by Backofen et al. ${ }^{\mathrm{UU}}$ in the deformation of a two-phase Ti-6Al-4V alloy. A metallographic examination of our $900^{\circ} \mathrm{C}$ specimens also revealed evidence of a two-phase structure. Superplasticity was reported ${ }^{20}$ for fine-grain Zircaloy-4 deformed in the transformation region. A detailed discussion of possible mechanisms of superplastic deformation of Zircaloy is included in Sec. VII.

5. Dynamic Strain Aging in Zircaloy near $700^{\circ} \mathrm{C}$

Strain aging has been observed in commercial zirconium, ${ }^{21}$ Zircaloy-2, ${ }^{22,23}$, zirconium alloys ${ }^{24}$ and zirconium-oxygen alloys ${ }^{25}$ in the 
temperature range of $150-500^{\circ} \mathrm{C}$. Strain aging at $250-300^{\circ} \mathrm{C}$ is generally attributed $^{25}$ to the presence of oxygen, whereas some controversy exists with regard to the element responsible for strain aging at $\sim 450^{\circ} \mathrm{C}$. Although Kelly and $\mathrm{Smith}^{25}$ suggest that strain aging at $450^{\circ} \mathrm{C}$ is due to carbon, Veevers ${ }^{24}$ attributes it to iron and, to some extent, oxygen. Our survey of the literature found no reference to strain aging in $\mathrm{Zircaloy}$ above $500^{\circ} \mathrm{C}$.

Since a yield point was consistently observed in the tensile tests of both $\mathrm{Zircaloy}-2$ and -4 near $700^{\circ} \mathrm{C}$, additional tests were conducted to evaluate phenomena responsible for this strain-aging effect. Figure 12 shows results for Zircaloy -2 specimens deformed at $700^{\circ} \mathrm{C}$. Curve $A$ is the partial load-elongation curve of an as-received sample (5.4-ks final anneal at $760^{\circ} \mathrm{C}$ ) strained to fracture at $700^{\circ} \mathrm{C}$ that shows a yield point. Curve $\mathrm{B}$ indicates the behavior of another as-received sample at $700^{\circ} \mathrm{C}$ strained to $\sim \epsilon=0.02$ and unloaded. Curve $C$ represents the deformation behavior of the sample from curve $B$ after a $14.4-\mathrm{ks}$ anneal at $800^{\circ} \mathrm{C}$. Pronounced serrations at regular intervals, which is a manifestation of dynamic strain aging (DSA), are observed in curve C. A complete discussion of DSA effect in Zircaloy is included after presentation of the $\mathrm{Zircaloy}-4$ DSA data.

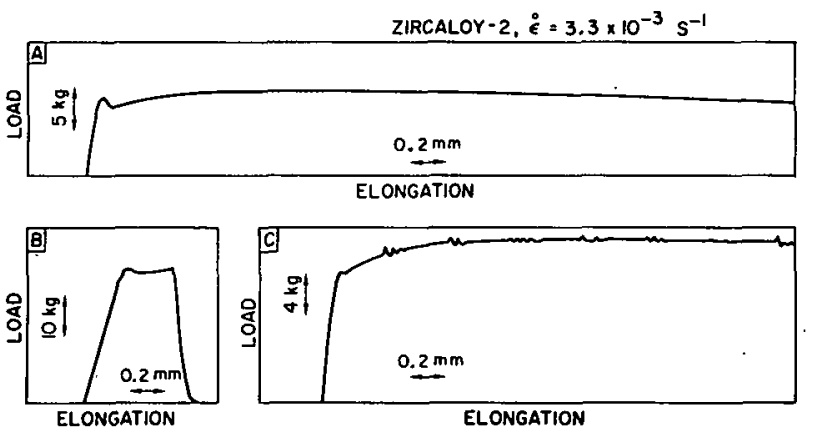

Fig. 12

Partial. Load-elongation Curves for Zircaloy-2 Specimens Deformed at $700^{\circ} \mathrm{C}$ after Various Heat Treatments. (A) As-received, strained to fracture; (B) as-received, partially strained; and (C) restrained to fracture following a 14.4-ks annealed at $800^{\circ} \mathrm{C}$ after B. Neg. No. MSD-63143.

\section{B. Zircaloy -2 /Oxygen Alloys}

Scoping tests were conducted to investigate the effect of oxygen on the properties of $\beta$ Zircaloy-? at 1300 and $1400^{\circ} \mathrm{C}$. Figure 13 shows the oxygenconcentration dependence of uniform and total strain of $\beta$ Zircaloy at 1300 and $1400^{\circ} \mathrm{C}$ at the strain rate of $3.3 \times 10^{-3} \mathrm{~s}^{-1}$. Near 0.34 wt $\%$ oxygen concentration, the uniform strain shows a minimum and the total strain shows a maximum. The oxygen-concentration dependence of yield stress and ultimate tensile strength is presented in Fig. 14. The significant grain growth observed at 1300 and $1400^{\circ} \mathrm{C}$ may be responsible for the complex nature of the data presented in Figs. 13 and 14. Similar data for a lower strain-rate of $3.3 \times 10^{-4} \mathrm{~s}^{-1}$ are shown in Fig. 15.

In general, oxygen increases the yield and ultimate tensile stresses and decreases the total and uniform strains. The influence of oxygen on the work-hardening parameters is presented in Table IV. Over the oxygenconcentration range investigated, oxygen appears to decrease the workhardening rate. 


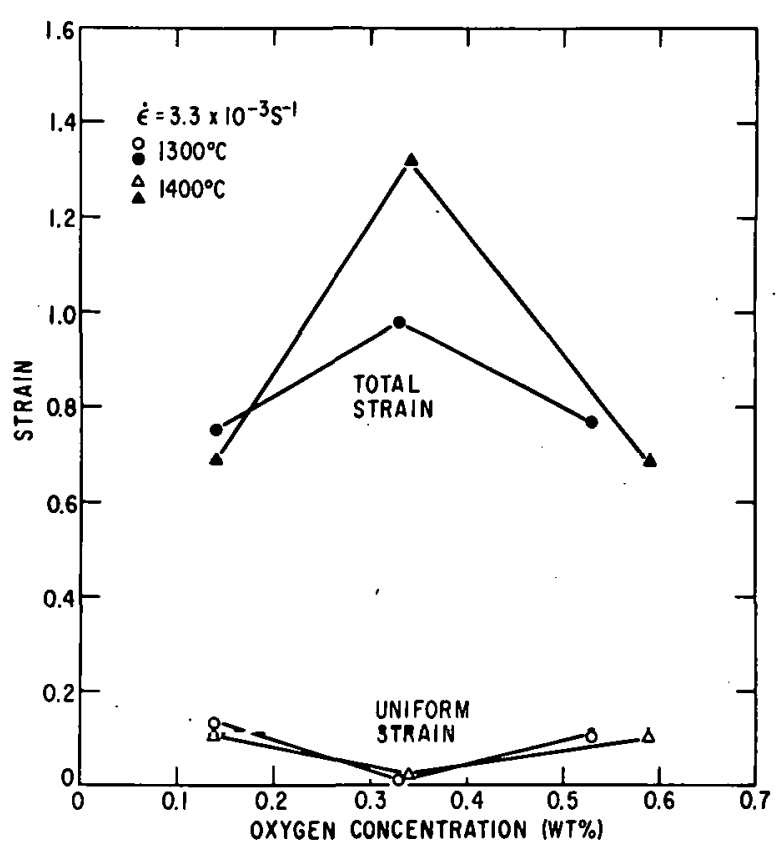

Fig. 13. Uniform and Total Strain as a Eunction of Oxygen Concentration for Zircaloy-2 Specimens at 1300 and $1400^{\circ} \mathrm{C}$. ANL Neg. No. 306-77-64 Rev. 1.

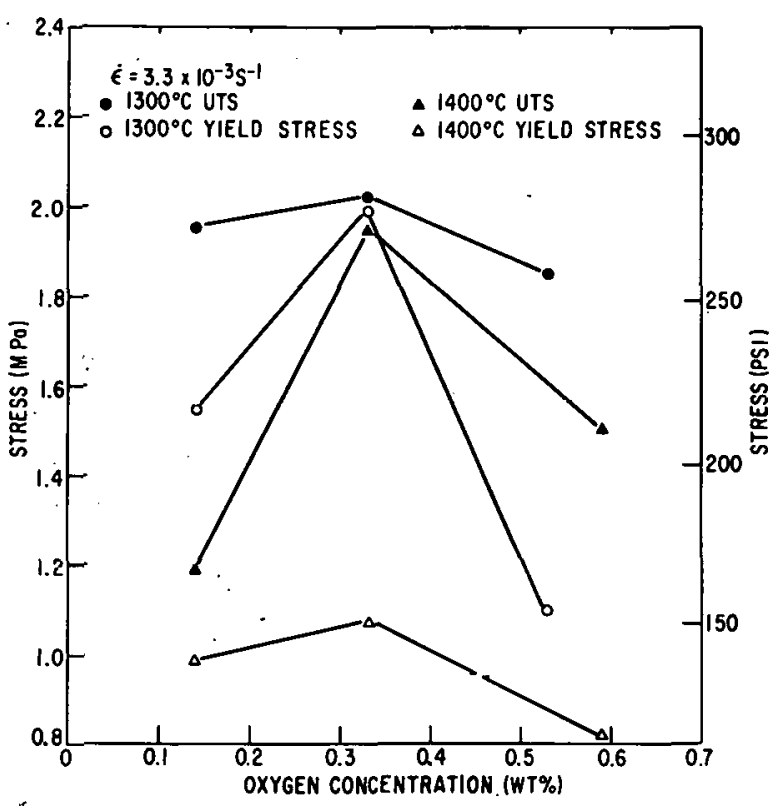

Fig. 14. Oxygen-concentration Dependence of Yield Stress and Ultimate Tensile Strength of Zircaloy-2 at 1300 and $1400^{\circ} \mathrm{C}$. ANL Neg. No. 306-77-63 Rev. 1.

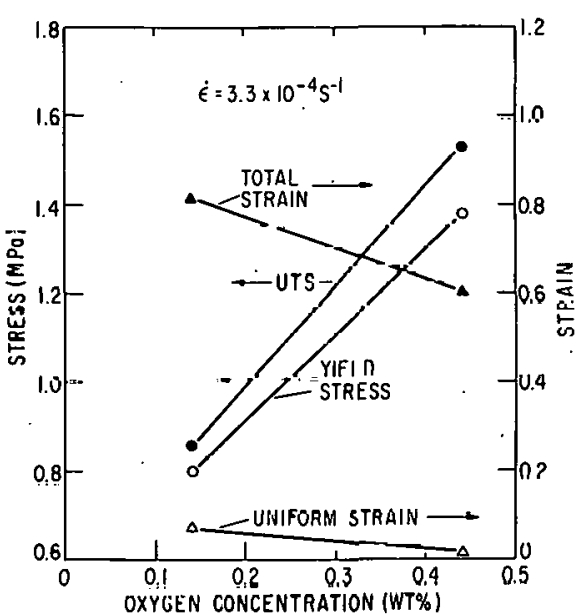

Fly. 13. Tolal scraln, Uniform strain, Yis.ld Strcss, and Ultimate Tensile Strength of Zircaloy-2 at $1300^{\circ} \mathrm{C}$ as a Function of Oxygen Concentration. ANI. Neg. No. 306-77-69 Rev. 1.
TABLE IV. Effect of Oxygen on Least-squares Work-hardening Constants for Deformation Stages. of Longitudinal $\beta$-phase Zircaloy- 2 Sperimens from Crussard-Jaoul Analysis; $\varepsilon=3.3 \times 10^{3} \mathrm{~s}^{-1}$

\begin{tabular}{ccccccc}
\hline $\begin{array}{c}\text { Temp, } \\
{ }^{\circ} \mathrm{C}\end{array}$ & $\begin{array}{c}\text { Oxygen, } \\
\text { wt \% }\end{array}$ & $\begin{array}{c}\text { Stage } \\
\text { Number }\end{array}$ & $\begin{array}{c}\text { Strain } \\
\text { Interval }\end{array}$ & $\mathrm{n}$ & $\mathrm{k}, \mathrm{P}_{\mathbf{a}}$ & $\begin{array}{c}\text { Average } \\
\sigma_{0} ; \Gamma_{\dot{u}}\end{array}$ \\
\hline 1300 & 0.14 & 1 & $0.0004-0.014$ & 0.88 & $8.2 \times 10^{6}$ & $1.5 \times 10^{6}$ \\
& & 2 & $0.014-0.11$ & 0.23 & $2.1 \times 10^{6}$ & $9.3 \times 10^{5}$ \\
$130 n$ & 0.33 & 1 & $0.0001-0.004$ & 0.17 & $6.6 \times 10^{5}$ & $1.8 \times 10^{6}$ \\
& & 2 & $0.004-0.007$ & -1.30 & $-2.7 \times 10^{1}$ & $2.0 \times 10^{6}$ \\
1400 & 0.14 & 1 & $0.0004-11.111$. & 1.00 & $4.3 \times 10^{6}$ & $1.1 \times 10^{6}$ \\
& & 2 & $0.013-0.09$ & 0.48 & $8.8 \times 10^{5}$ & $1.0 \times 10^{6}$ \\
1400 & 0.31 & 1 & $0.0004-0.009$ & 0.60 & $1.7 \times 10^{7}$ & $6.8 \times 10^{5}$ \\
& & 2 & $0.01-0.025$ & -1.70 & $-1.2 \times 10^{2}$ & $2.1 \times 10^{6}$ \\
1400 & 0.59 & 1 & $0.0004-0.013$ & 0.81 & $1.2 \times 10^{7}$ & $7.4 \times 10^{5}$ \\
& & 2 & $0.014-0.090$ & -0.07 & $-3.1 \times 10^{6}$ & $5.3 \times 10^{6}$ \\
\hline
\end{tabular}




\section{MECHANICAL PROPERTIES OF ZIR CALOY -4}

A. As-received Zircaloy -4

\section{Stress-Strain Curves}

Figures 16 and 17 represent the engineering-stress/engineeringstrain curves of $\mathrm{Zircaloy}-4$ specimens deformed at a strain rate of $3.3 \mathrm{x}$ $10^{-3} \mathrm{~s}^{-1}$ for different temperatures. Figures 18 and 19 show Zircaloy -4 stressstrain curves at a faster strain rate. The general shape of these curves is similar to those for Zircaloy-2 in Sec. III.A.l. At both strain rates, the Zircaloy -4 specimens show superplastic elongations between 800 and $1000^{\circ} \mathrm{C}$.

The temperature variation of the ultimate tensile strength of Zircaloy -4 at three strain rates is plotted in Fig. 20. A tendency toward a plateau formation in the temperature interval $400-500^{\circ} \mathrm{C}$ (Fig. 20a) is a mani festation of dynamic strain aging. An increasing extent of dynamic recovery may be responsible for the rapid drop in the ultimate tensile strength as the temperature increases from 700 to $1000^{\circ} \mathrm{C}$ (Fig. 20b).

Figure 21 shows the effect of temperature and strain rate on the uniform and total strain of Zircaloy-1. In Fig. 2 la, the tendency for a maximum uniform strain near $200^{\circ} \mathrm{C}\left(\dot{\varepsilon}=3.3 \times 10^{-3} \mathrm{~s}^{-1}\right)$ and a minimum in total strain near $550^{\circ} \mathrm{C}\left(\dot{\epsilon}=3.3 \times 10^{-2} \mathrm{~s}^{-1}\right)$ provide indications of dynamic strain aging. Note that, at the three strain rates in Fig. $21 \mathrm{~b}$, a maximum in total

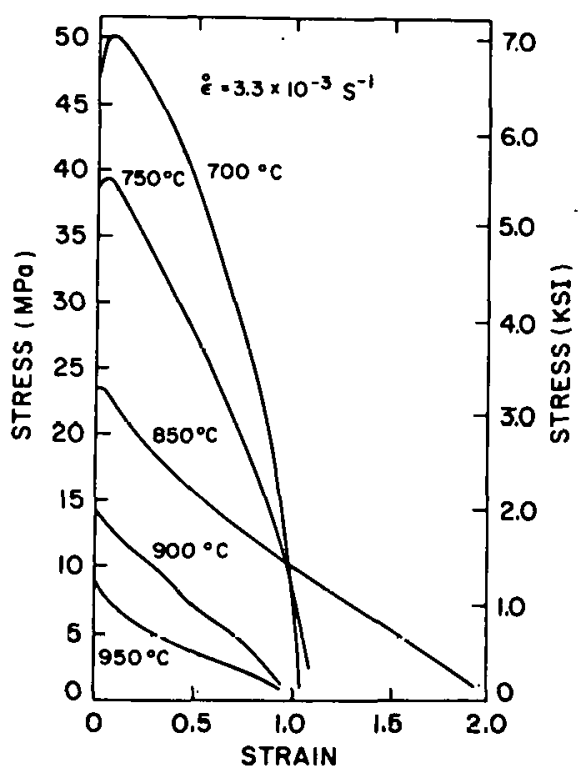

Fig. 16. Engineering-stress/Engineeringstrain Curves for Zircaloy-4 Specimens Deformed at 700 , $750,850,900$, and $950^{\circ} \mathrm{C}$. Neg. No. MSD-61494.

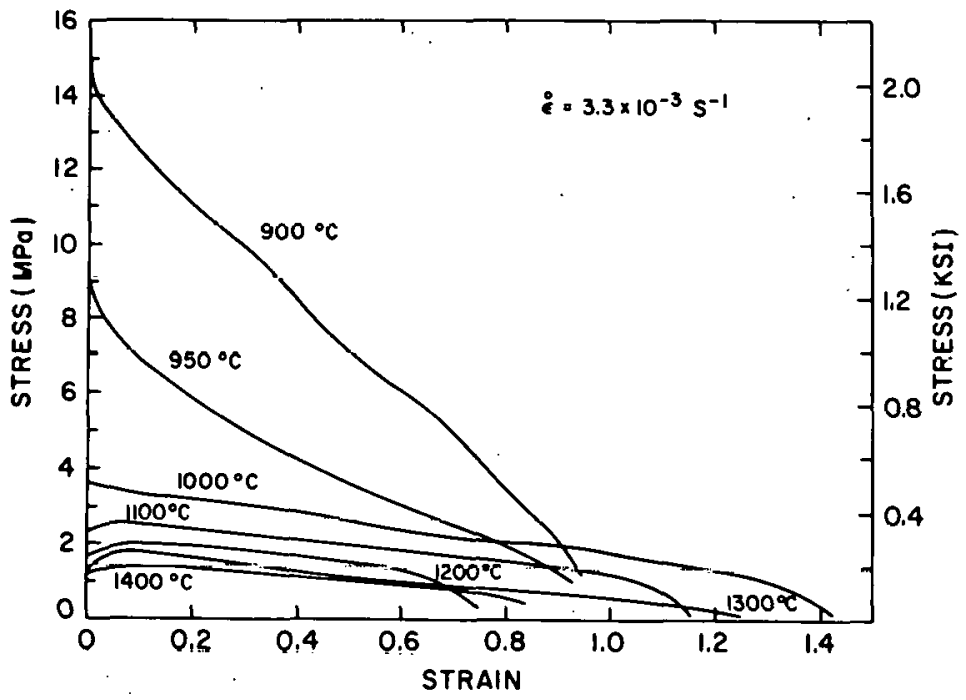

Fig. 17. Engineering-stress/Engineering-strain Curves for Zircaloy-4 Specimens Deformed at 900 . $950,1000,1100,1200,1300$, and $1400^{\circ} \mathrm{C}$. Neg. No. MSD-61489. 


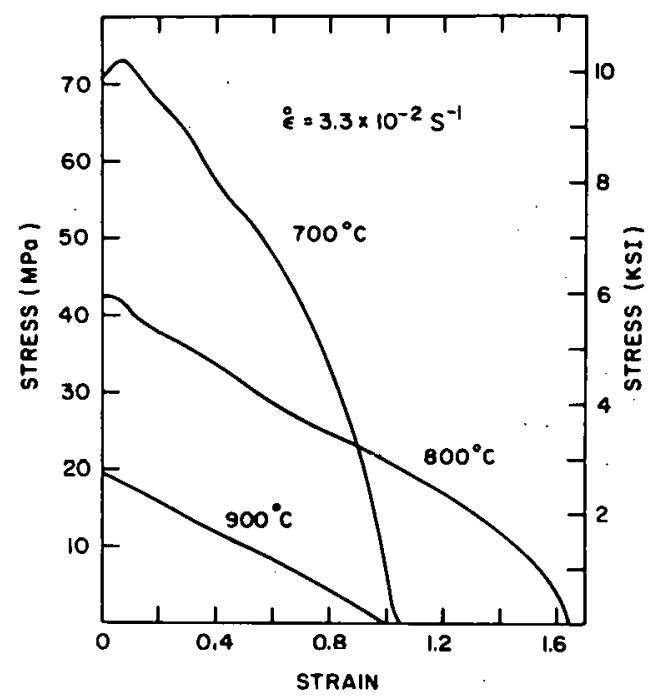

Fig. 18. Engineering-stress/Engineering-strain Curves for Zircaloy-4 Specimens Deformed at 700,800 , and $900^{\circ} \mathrm{C}$. Neg. No. MSD-61497.

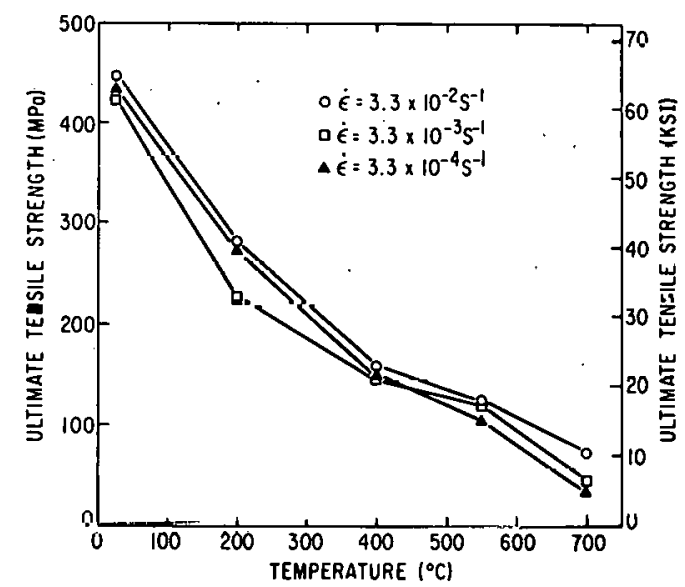

(a)

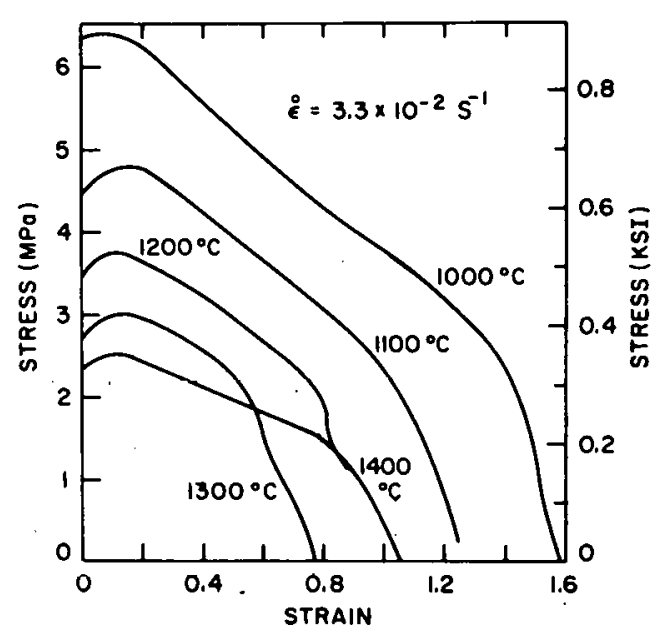

Fig. 19. Engineering-stress/Engineering-strain Curves for Zircaloy-4 Specimens Deformed at $1000,1100,1200,1300$, and $1400^{\circ} \mathrm{C}$. Neg. No. MSD-61503.

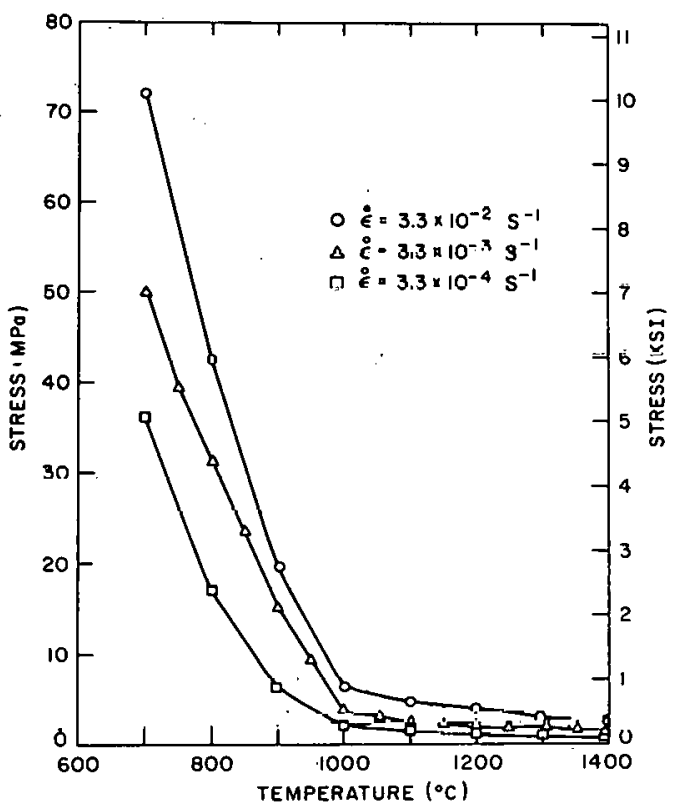

(b)

Fig. 20. Ultimate Tensile Strength of Zircaloy-4 at Three Strain Rates over Two Temperature Intervals. (a) $23-700^{\circ} \mathrm{C}$ and (b) $700-1400^{\circ} \mathrm{C}$. ANL Neg. No. 306-77-67 Rev. 1 and MSD-61498. 


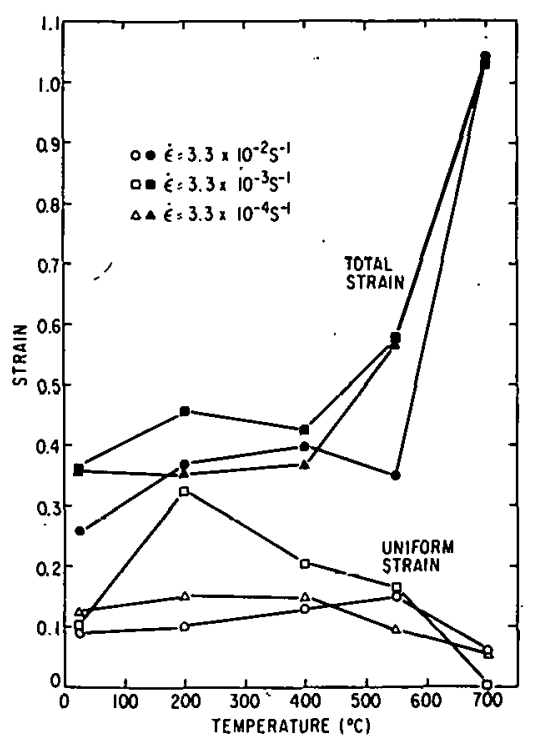

(a)

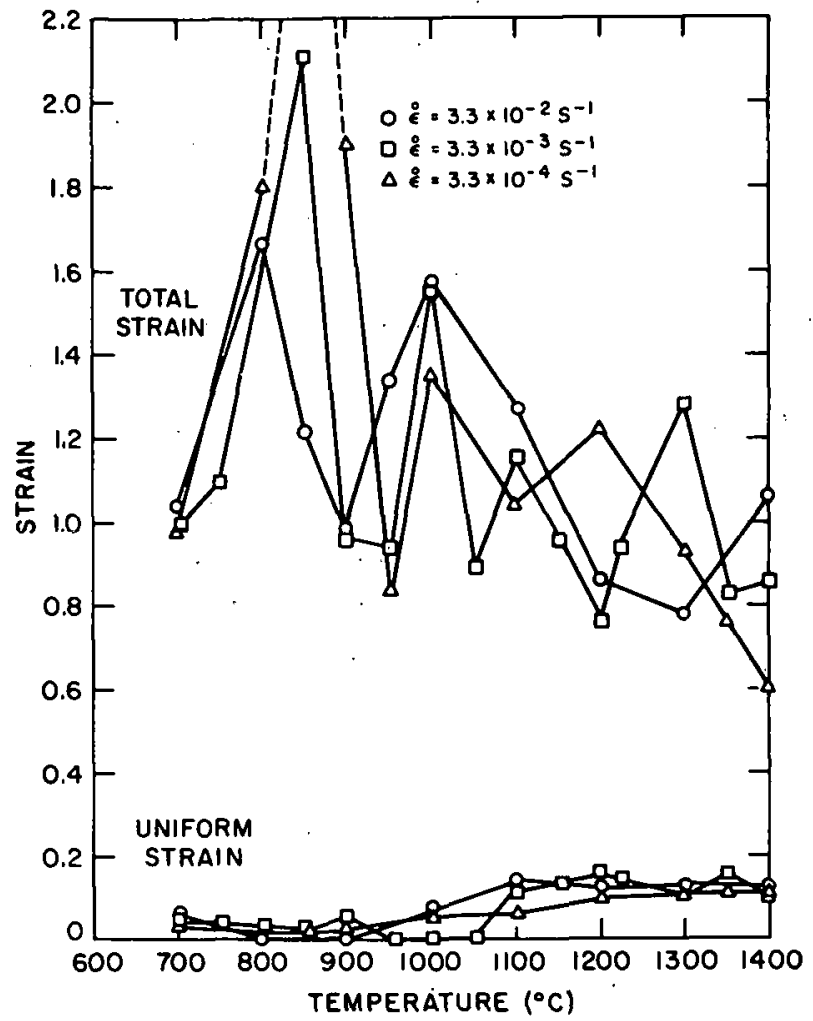

(b)

Fig. 21. Uniform Strain and Total Strain for Zircaloy-4 Specimens as a Function of Deformation Temperature at Three Strain Rates. (a) $23-700^{\circ} \mathrm{C}$ and

(b) $700-1400^{\circ} \mathrm{C}$. ANL Neg. Nos. 306-77-54 Rev. 1 and 306-75-199 Rev. 1 .

strain occurs in the temperature interval $800-850^{\circ} \mathrm{C}$, i.e., in the two-phase region near the $\alpha$-phase boundary, which increases as the strain rate decreases. For a strain rate of $3.3 \times 10^{-4} \mathrm{~s}^{-1}$, failure did not occur after $285 \%$ strain and no concentrated neck was observed in the deformed gauge region. The test was terminated because the specimen length exceeded the uniform temperature zone in the furnace. The larger total strains at lower strain rates are consistent with the well-documented fact that superplasticity is enchanced at slower stirain rates.

Note that the maxima at $800-850$ and at $-1000^{\circ} \mathrm{C}$ and the minimum at $900-950^{\circ} \mathrm{C}$ in Fig. 21 resemble the hoop-strain-versus-temperature data obtained on internally pressurized tubes. ${ }^{26-29}$ Although the correlation between uniaxial and biaxial mechanical properties is not simple, the same microstructural factors may be responsible for the strain-temperature behavior in the two cases. Although the deformation behavior above $1100^{\circ} \mathrm{C}$ is complicated by a substantial amount of grain growth, the elongation peak at $-1300^{\circ} \mathrm{C}$ is probably representative of the material behavior, since a similar peak was also observed during tube-burst tests on Zircaloy under transient-heating conditions, ${ }^{30}$ in which grain growth occurred to a lesser extent. 
Deriving true-stress/true-strain curves for Zircaloy-4 specimens (i.e., from the data shown in Figs. 16-19) was difficult because the maximum load point on each curve appeared at small strains. The neck profile could noti be measured because the specimens were enclosed in the vacuum chamber during tensile testing. The true-stress/true-strain data could be obtained only by straining several samples to different levels at a constant temperature, unloading, and measuring the minimum cross section. Data obtained in this fashion at $900^{\circ} \mathrm{C}$ are shown in Fig. 22. The true stress is almost constant from 0.2 to 0.97 (fracture point) true strain. A visible neck was observed in speci mens strained beyond $\epsilon=0.30$.

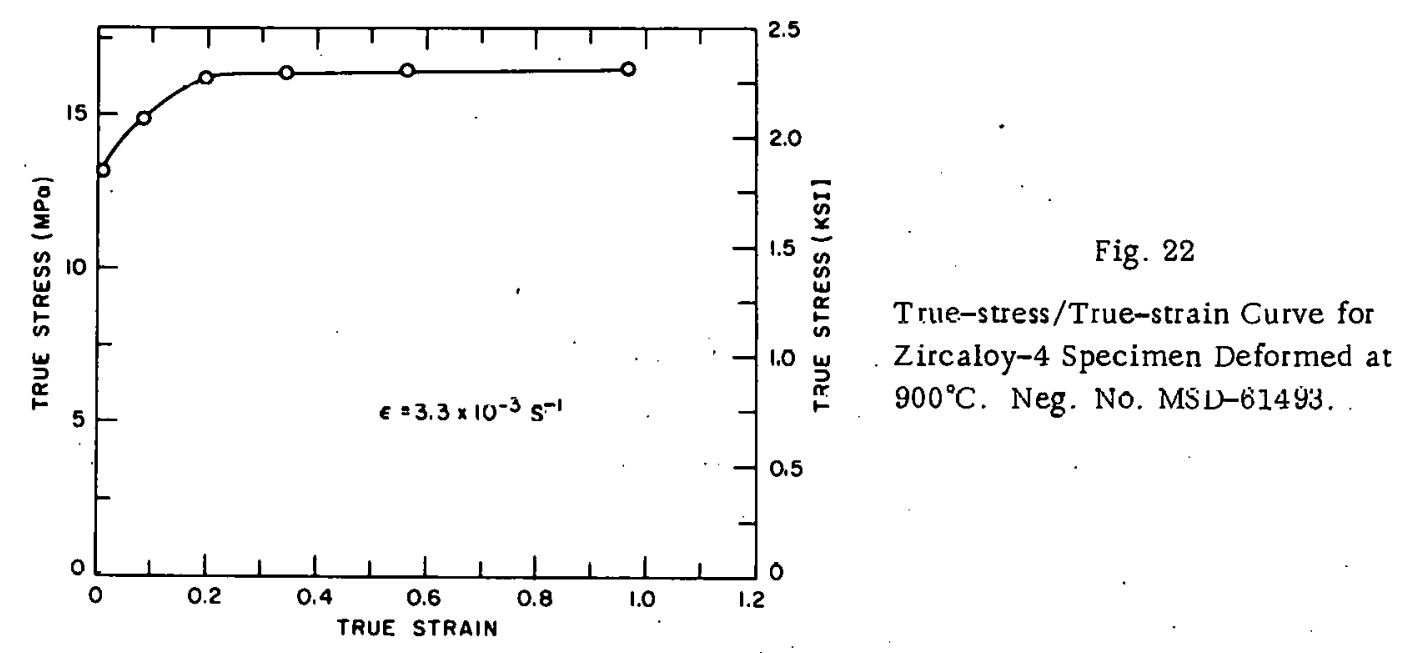

\section{Strain-rate Sensitivity}

The effect of strain on the strain-rate sensitivity of Zircaloy-1 is shown in Figs. 23 and 24. Below $\epsilon=0.05$, the strain-rate sensitivity decreases

Fig. 23

Strain Dependence of Strainrate Sensitivity of Zircaloy-4 at Various Temperatures. Neg. No. MSD-61485.

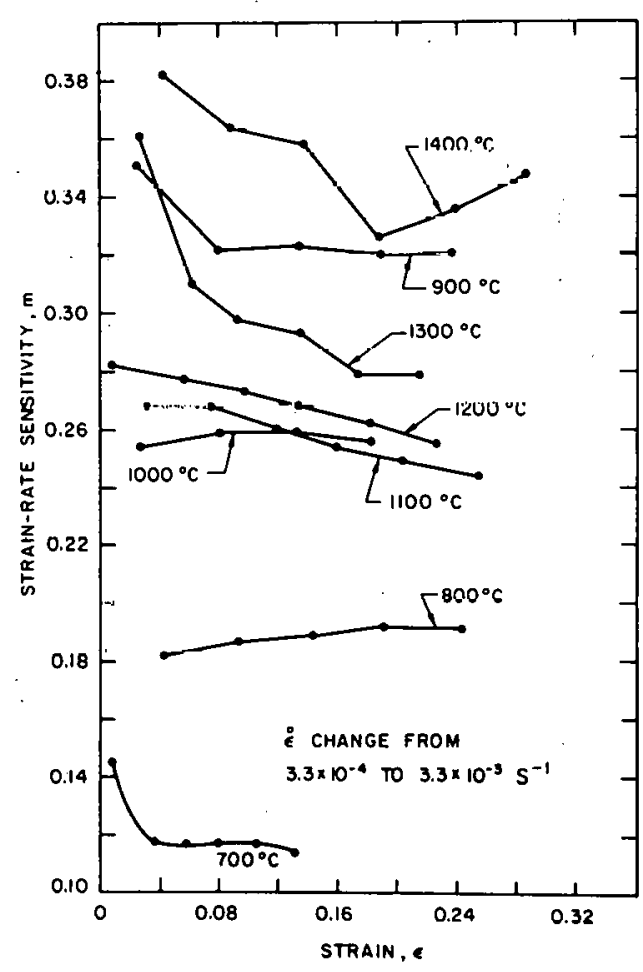




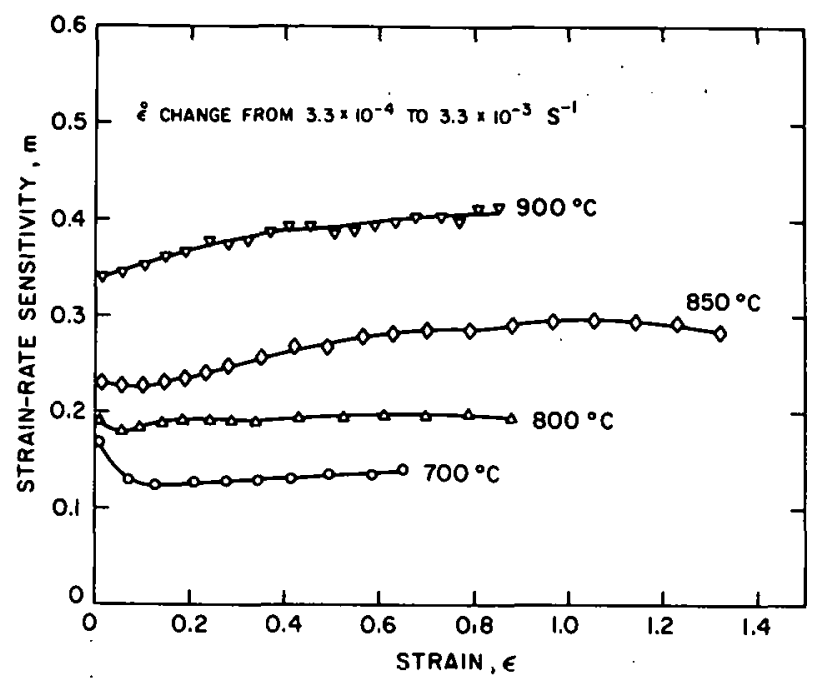

Fig. 24

Strain Dependence of Strain-rate Sensitivity of Zircaloy-4 at 700, 800, 850 , and $900^{\circ} \mathrm{C}$. Neg. Nö. MSD-61492.

at all temperatures as the strain increases. Beyond $\epsilon=0.05$, at temperatures where superplastic deformation is observed (i.e., at 800,900 , and $1000^{\circ} \mathrm{C}$ ), the strain-rate sensitivity either remains constant or increases as the strain increases. For other temperatures at higher strains, strain-rate sensitivity continues to decrease as the strain increases. As stated earlier, necking is not evident even after several percent strain beyond the maximum load point under superplastic deformation conditions. The strain-rate increase due to neck formation is not significant in such cases; therefore, at $700,800,850$, and $900^{\circ} \mathrm{C}$ strain-rate cycling was continued to much larger strain values (Fig. 24). Note that at 850 and $900^{\circ} \mathrm{C}$, where the extent of superplastic elongation is large, $m$ actually increases with strain up to $\epsilon \simeq 0.9$.

Figure 25 shows the effect of strain and strain rate on the strainrate sensitivity of $\mathrm{Zircaloy}-4$ at 800,900 , and $1000^{\circ} \mathrm{C}$. In the single-phase region, at 800 and $1000^{\circ} \mathrm{C}$, the strain-rate sensitivity is almost insensitive to strain rate, whereas in the two-phase region, at $900^{\circ} \mathrm{C}$, the strain-rate

Fig. 25

Effect of Strain and Strain Rate on Strainrate Sensitivity of Zircaloy-4 at 800,900 , and $1000^{\circ} \mathrm{C}$. Neg. No. MSD-61499.

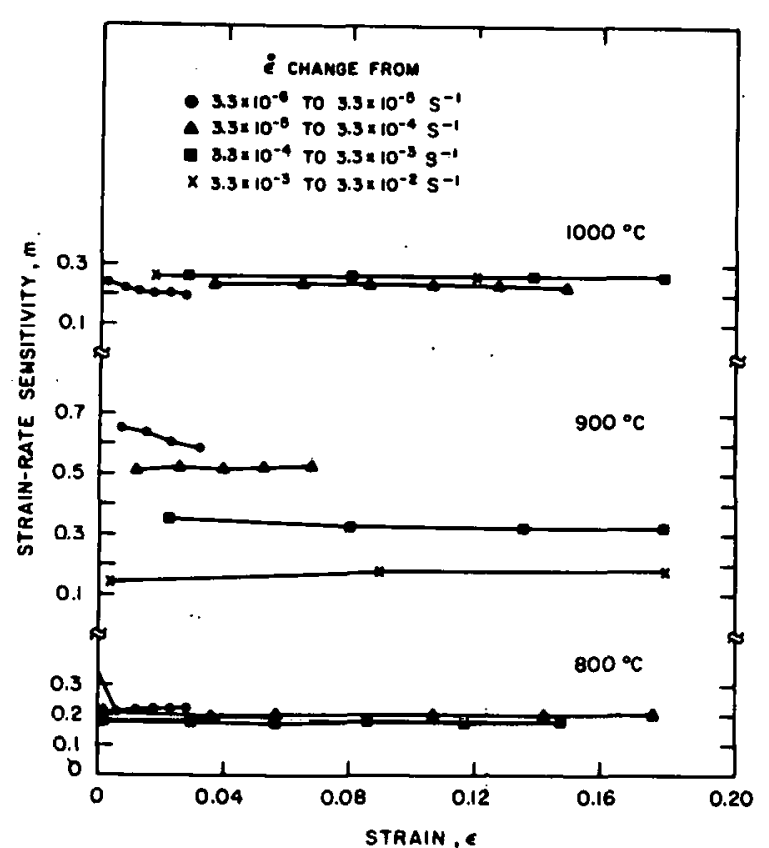


sensitivity is rather sensitive to strain rate. These data are presented in a different format in Fig. 26. Note that at $900^{\circ} \mathrm{C}$, both Zircaloy-2 and -4 data show similar behavior. The temperature dependence of the strain-rate sensitivity of Zircaloy-4 was shown in Fig. 8.

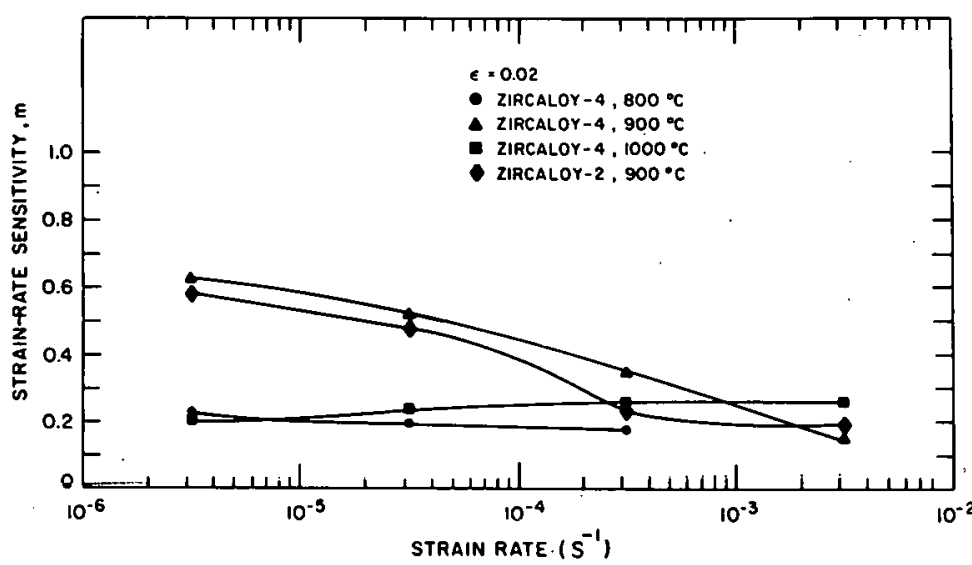

Fig. 26

Strain-rate Dependence of Strain-rate Sensitivity of Zircaloy at 800,900 , and $1000^{\circ} \mathrm{C}$. Neg. No. MSD -61486 .

Figure 27 shows the effect of strain on the strain-rate sensitivity of as -received $\mathrm{Zircaloy}-4$ at $850^{\circ} \mathrm{C}$. The four curves are for different ranges of strain-rate change. As the starting strain rate decreases from $3.3 \times 10^{-3}$ to $3.3 \times 10^{-6} \mathrm{~s}^{-1}$, the average value of the strain-rate sensitivity increases from 0.2 to 0.75 . This observation is consistent with the data in Fig. 21 , which show that the superplastic elongation peak at $850^{\circ} \mathrm{C}$ is strongly dependent on strain rate. The total elongation at $850^{\circ} \mathrm{C}$ increases with a decrease in strain rate. These results show that the amount of the tensile elongation under superplastic detormation conditions is related to the magnitude of the strain-rate scnsitivity.

Fig. '27

Strain-rate Sensitivity of As-received Zircaloy-4 at $850^{\circ} \mathrm{C}$ as a Function of Strain. The four curves are for different strain-rate ranges; (A) $3.3 \times 10^{-6}$ to $3.3 \times 10^{-5} \mathrm{~s}^{-1}$, (B) $3.3 \times 10^{-5}$ to $3.3 \times 10^{-4} \mathrm{~s}^{-1}$, (C) $3.3 \times 10^{-4}$ to $3.3 \times 10^{-3} \mathrm{~s}^{-1}$. (D) $3.3 \times 10^{-3}$ to $3.3 \times 10^{-2} \mathrm{~s}^{-1}$. ANL Neg. No. 306-76-10.

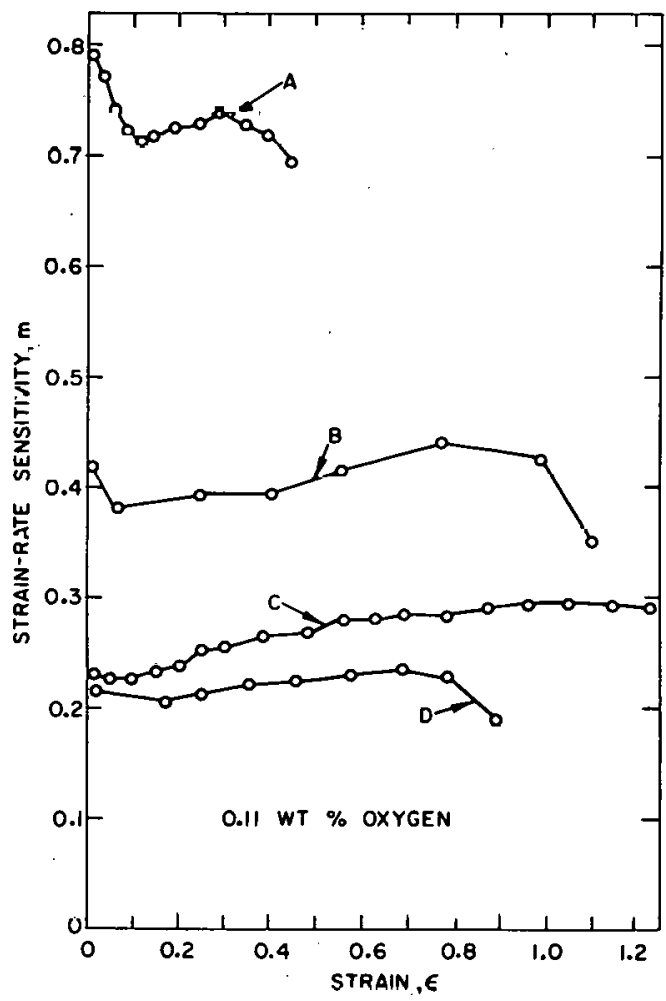




\section{Work-hardening Analysis}

The Crussard-Jaoul work-hardening analysis was also applied to $\mathrm{Zircaloy}-4$ tensile data. The results are shown in Tables V-VII and Figs. 28-31. The temperature dependence of the work-hardening exponent for the stage covering the major portion of the uniform strain region at three strain rates is plotted in Fig. 29. In the $\alpha$-phase region $\left(\$ 805^{\circ} \mathrm{C}\right)$, peak values of the work-hardening exponent are observed at $200^{\circ}$ and near $700^{\circ} \mathrm{C}$. At these two temperature regions, dynamic-strain-aging effects are observed. Positive work-hardening exponents are observed below $600^{\circ} \mathrm{C}$, where transgranular de formation is important. In the two-phase region $\left(810-980^{\circ} \mathrm{C}\right)$, negative workhardening exponents are observed due to intergranular deformation (grainboundary sliding). At lower strain rates, the extent of grain-boundary sliding is greater, and the work -hardening exponent therefore as sumes larger negative values over a wider temperature interval.

TABLE V. Least-squares Work-hardening Constants for Deformation Stages of As-received Longitudinal Zircaloy -4 Specimens from Crussard-Jaoul Analysis; $\dot{\varepsilon}=3.3 \times 10^{-2} \mathrm{~s}^{-1}$

\begin{tabular}{|c|c|c|c|c|c|}
\hline${ }^{\text {Temp }}$ & $\begin{array}{l}\text { Stage } \\
\text { Number }\end{array}$ & $\begin{array}{l}\text { Strain } \\
\text { Interval }\end{array}$ & $\mathrm{n}$ & $\mathrm{k}, \mathrm{Pa}$ & $\begin{array}{c}\text { Average } \\
\sigma_{0}, \mathrm{~Pa}\end{array}$ \\
\hline 23 & 2 & $0.0004-0.07$ & 0.31 & $3.7 \times 10^{8}$ & $3.3 \times 10^{8}$ \\
\hline 200 & $\begin{array}{l}2 \\
3\end{array}$ & $\begin{array}{l}0.011-0.03 \\
0.035-0.07\end{array}$ & $\begin{array}{r}0.96 \\
-0.36\end{array}$ & $\begin{array}{r}8.9 \times 10^{8} \\
-3.0 \times 10^{7}\end{array}$ & $\begin{array}{l}2.5 \times 10^{8} \\
3.8 \times 10^{8}\end{array}$ \\
\hline 400 & $\begin{array}{l}2 \\
3\end{array}$ & $\begin{array}{c}0.0004-0.015 \\
0.020-0.09\end{array}$ & $\begin{array}{r}0.94 \\
-0.16\end{array}$ & $\begin{array}{r}1.1 \times 10^{9} \\
-8.4 \times 10^{7}\end{array}$ & $\begin{array}{l}1.2 \times 10^{8} \\
3.0 \times 10^{8}\end{array}$ \\
\hline 550 & $\begin{array}{l}2 \\
3\end{array}$ & $\begin{array}{c}0.0004-0.013 \\
0.014-0.11\end{array}$ & $\begin{array}{l}0.92 \\
0.03\end{array}$ & $\begin{array}{l}9.3 \times 10^{8} \\
5.7 \times 10^{8}\end{array}$ & $\begin{array}{r}8.9 \times 10^{7} \\
-3.9 \times 10^{8}\end{array}$ \\
\hline 700 & 2 & $0.0004-0.05$ & 0.86 & $8.1 \times 10^{7}$ & $6.8 \times 10^{7}$ \\
\hline 750 & 2 & $0.011-0.05$ & $0.89^{\circ}$ & $7.7 \times 10^{7}$ & $6.1 \times 10^{7}$ \\
\hline 1000 & $\begin{array}{l}1 \\
2\end{array}$ & $\begin{array}{l}0.0004-0.0020 \\
0.0024-0.07\end{array}$ & $\begin{array}{r}0.83 \\
-0.26\end{array}$ & $\begin{array}{r}1.7 \times 10^{8} \\
-6.9 \times 10^{5}\end{array}$ & $\begin{array}{l}4.3 \times 10^{6} \\
8.7 \times 10^{6}\end{array}$ \\
\hline 1100 & $\begin{array}{l}1 \\
2\end{array}$ & $\begin{array}{c}0.0004-0.014 \\
0.015-0.11\end{array}$ & $\begin{array}{l}0.98 \\
0.64\end{array}$ & $\begin{array}{l}1.2 \times 10^{7} \\
4.5 \times 10^{6}\end{array}$ & $\begin{array}{l}4.3 \times 10^{6} \\
4.2 \times 10^{6}\end{array}$ \\
\hline 1200 & $\begin{array}{l}1 \\
2\end{array}$ & $\begin{array}{c}0.004-0.025 \\
0.03-0.11\end{array}$ & $\begin{array}{l}0.97 \\
0.39\end{array}$ & $\begin{array}{l}8.3 \times 10^{6} \\
2.8 \times 10^{6}\end{array}$ & $\begin{array}{l}3.3 \times 10^{6} \\
2.9 \times 10^{6}\end{array}$ \\
\hline 1300 & $\begin{array}{l}1 \\
2\end{array}$ & $\begin{array}{c}0.0004-0.014 \\
0.015-0.11\end{array}$ & $\begin{array}{l}0.98 \\
0.59\end{array}$ & $\begin{array}{l}7.7 \times 10^{6} \\
2.7 \times 10^{6}\end{array}$ & $\begin{array}{l}2.6 \times 10^{6} \\
2.5 \times 10^{6}\end{array}$ \\
\hline 1400 & $\begin{array}{l}1 \\
2\end{array}$ & $\begin{array}{c}0.0004-0.015 \\
0.02-0.09\end{array}$ & $\begin{array}{l}0.98 \\
0.61\end{array}$ & $\begin{array}{l}5.1 \times 10^{6} \\
1.9 \times 10^{6}\end{array}$ & $\begin{array}{l}2.3 \times 10^{6} \\
2.2 \times 10^{6}\end{array}$ \\
\hline
\end{tabular}


TABLE VI. Least-squares Work-hardening Constants for Deformation Stages of As-received Longitudinal Zircaloy-4 Specimens from

Crussard-Jaoul Analysis; $\dot{\varepsilon}=3.3 \times 10^{-3} \mathrm{~s}^{-1}$

\begin{tabular}{|c|c|c|c|c|c|}
\hline$\underset{{ }^{\circ} \mathrm{C}}{\text { Temp }}$ & $\begin{array}{l}\text { Stage } \\
\text { Number }\end{array}$ & $\begin{array}{l}\text { Strain } \\
\text { Interval }\end{array}$ & $\mathrm{n}$ & $\mathrm{k}, \mathrm{Pa}$ & $\begin{array}{c}\text { Average } \\
\sigma_{0}, \mathrm{~Pa}\end{array}$ \\
\hline 23 & $\begin{array}{l}1 \\
2\end{array}$ & $\begin{array}{l}0.0004-0.0028 \\
0.0032-0.09\end{array}$ & $\begin{array}{l}0.11 \\
0.54\end{array}$ & $\begin{array}{l}2.5 \times 10^{8} \\
4.4 \times 10^{8}\end{array}$ & $\begin{array}{l}2.4 \times 10^{8} \\
3.5 \times 10^{8}\end{array}$ \\
\hline 200 & 2 & $0.0036-0.23$ & 0.86 & $4.4 \times 10^{8}$ & $1.8 \times 10^{8}$ \\
\hline 400 & 2 & $0.0004-0.15$ & 0.26 & $2.0 \times 10^{8}$ & $6.5 \times 10^{7}$ \\
\hline 550 & $\begin{array}{l}1 \\
2 \\
3\end{array}$ & $\begin{array}{c}0.0004-0.0036 \\
0.0040-0.014 \\
0.015-0.17\end{array}$ & $\begin{array}{l}0.05 \\
0.82 \\
0.21\end{array}$ & $\begin{array}{l}1.2 \times 10^{8} \\
5.6 \times 10^{8} \\
1.3 \times 10^{8}\end{array}$ & $\begin{array}{l}4.1 \times 10^{6} \\
8.7 \times 10^{7} \\
5.0 \times 10^{7}\end{array}$ \\
\hline 700 & 2 & $0.006-0.05$ & 0.46 & $3.2 \times 10^{7}$ & $4.3 \times 10^{7}$ \\
\hline 750 & 2 & $0.008-0.035$ & 0.68 & $2.8 \times 10^{7}$ & $3.7 \times 10^{7}$ \\
\hline 800 & $\begin{array}{l}1 \\
2\end{array}$ & $\begin{array}{l}0.0004-0.0012 \\
0.0016-0.025\end{array}$ & $\begin{array}{r}0.36 \\
-0.04\end{array}$ & $\begin{array}{r}7.1 \times 10^{7} \\
-2.2 \times 10^{7}\end{array}$ & $\begin{array}{l}1.9 \times 10^{7} \\
5.5 \times 10^{7}\end{array}$ \\
\hline 850 & $\begin{array}{l}1 \\
2\end{array}$ & $\begin{array}{l}0.0004-0.0016 \\
0.0016-0.015\end{array}$ & $\begin{array}{r}0.06 \\
-0.30\end{array}$ & $\begin{array}{r}4.4 \times 10^{7} \\
-5.5 \times 10^{5}\end{array}$ & $\begin{array}{r}-8.8 \times 10^{6} \\
2.5 \times 10^{7}\end{array}$ \\
\hline 900 & $\begin{array}{l}1 \\
2\end{array}$ & $\begin{array}{l}0.0004-0.002 \\
0.0024-0.0032\end{array}$ & $\begin{array}{l}-0.08 \\
-7.00\end{array}$ & $\begin{array}{l}-6.6 \times 10^{6} \\
-5.8 \times 10^{-14}\end{array}$ & $\begin{array}{l}2.5 \times 10^{7} \\
1.5 \times 10^{7}\end{array}$ \\
\hline 950 & 2 & $0.0004-0.0016$ & -0.65 & $-8.5 \times 10^{3}$ & $9.5 \times 10^{6}$ \\
\hline 1000 & $\begin{array}{l}1 \\
2\end{array}$ & $\begin{array}{r}0.0004-0.004 \\
0.005-0.025\end{array}$ & $\begin{array}{r}0.37 \\
-0.85\end{array}$ & $\begin{array}{r}6.5 \times 10^{6} \\
-4.6 \times 10^{3}\end{array}$ & $\begin{array}{l}2.8 \times 10^{6} \\
4.1 \times 10^{6}\end{array}$ \\
\hline 1050 & $\begin{array}{l}1 \\
2 \\
3\end{array}$ & $\begin{array}{l}0.0004-0.0012 \\
0.0016-0.0036 \\
0.0036-0.006\end{array}$ & $\begin{array}{r}-0.46 \\
0.49 \\
-1.80\end{array}$ & $\begin{array}{r}-3.1 \times 10^{3} \\
1.9 \times 10^{6} \\
-1.5 \times 10^{0}\end{array}$ & $\begin{array}{l}2.9 \times 10^{6} \\
2.8 \times 10^{6} \\
2.9 \times 10^{6}\end{array}$ \\
\hline 1100 & 2 & $0.0004-0.09$ & 0.04 & $3.2 \times 10^{6}$ & $-3.0 \times 10^{5}$ \\
\hline 1150 & $\begin{array}{l}1 \\
2 \\
3\end{array}$ & $\begin{array}{c}0.0004-0.005 \\
0.005-0.01 \\
0.01-0.11\end{array}$ & $\begin{array}{l}0.52 \\
0.77 \\
0.55\end{array}$ & $\begin{array}{l}1.4 \times 10^{6} \\
3.5 \times 10^{6} \\
1.9 \times 10^{6}\end{array}$ & $\begin{array}{l}1.9 \times 10^{6} \\
1.9 \times 10^{6} \\
1.9 \times 10^{6}\end{array}$ \\
\hline 1200 & $\begin{array}{l}1 \\
2\end{array}$ & $\begin{array}{l}0.0004-0.0032 \\
0.0026-0.13\end{array}$ & $\begin{array}{l}0.91 \\
0.1 \%\end{array}$ & $\begin{array}{l}4.1 \times 10^{7} \\
2.3 \times 10^{6}\end{array}$ & $\begin{array}{l}1.2 \times 10^{6} \\
6.0 \times 10^{5}\end{array}$ \\
\hline 1250 & $\begin{array}{l}1 \\
2\end{array}$ & $\begin{array}{c}0.0004-0.005 \\
0.005-0.13\end{array}$ & $\begin{array}{l}0.67 \\
0.28\end{array}$ & $\begin{array}{l}5.9 \times 10^{6} \\
1.7 \times 10^{6}\end{array}$ & $\begin{array}{l}1.2 \times 10^{6} \\
9.5 \times 10^{5}\end{array}$ \\
\hline 1300 & 2 & $0.0024-0.09$ & 0.68 & $3.1 \times 10^{6}$ & $1.3 \times 10^{6}$ \\
\hline 1350 & 2 & $0.0028-0.11$ & 0.64 & $1.4 \times 10^{6}$ & $1.2 \times 10^{6}$ \\
\hline 1400 & 2 & $0.0032-0.09$ & 0.89 & $1.8 \times 10^{6}$ & $1.3 \times 10^{6}$ \\
\hline
\end{tabular}


TABLE VII. Least-squares Work-hardening Constants for Deformation Stages of As-received Longitudinal Zircaloy-4 Specimens from

Crussard-Jaoul Analysis; $\dot{e}=3.3 \times 10^{-4} \mathrm{~s}^{-1}$

\begin{tabular}{|c|c|c|c|c|c|}
\hline$\underset{{ }^{\circ} \mathrm{C}}{\mathrm{Temp}}$ & $\begin{array}{l}\text { Stage } \\
\text { Number }\end{array}$ & $\begin{array}{l}\text { Strain } \\
\text { Interval }\end{array}$ & $\mathrm{n}$ & $\mathrm{k}, \mathrm{Pa}$ & $\begin{array}{c}\text { Average } \\
\sigma_{0}, \mathrm{~Pa}\end{array}$ \\
\hline 23 & 2 & $0.0004-0.09$ & 0.31 & $3.5 \times 10^{8}$ & $2.8 \times 10^{8}$ \\
\hline 200 & $\begin{array}{l}2 \\
3\end{array}$ & $\begin{array}{l}0.005-0.02 \\
0.025-0.11\end{array}$ & $\begin{array}{r}0.98 \\
-0.30\end{array}$ & $\begin{array}{r}2.1 \times 10^{9} \\
-6.5 \times 10^{7}\end{array}$ & $\begin{array}{l}1.8 \times 10^{8} \\
4.3 \times 10^{8}\end{array}$ \\
\hline 400 & $\begin{array}{l}1 \\
2 \\
3\end{array}$ & $\begin{array}{c}0.0004-0.0028 \\
0.0032-0.014 \\
0.015-0.11\end{array}$ & $\begin{array}{r}0.34 \\
0.81 \\
-0.08\end{array}$ & $\begin{array}{r}1.7 \times 10^{8} \\
8.7 \times 10^{8} \\
-2.3 \times 10^{8}\end{array}$ & $\begin{array}{l}7.0 \times 10^{7} \\
8.7 \times 10^{7} \\
4.5 \times 10^{8}\end{array}$ \\
\hline $550^{\circ}$ & $\begin{array}{l}1 \\
2 \\
3\end{array}$ & $\begin{array}{c}0.0004-0.0024 \\
0.0028-0.02 \\
0.025-0.09\end{array}$ & $\begin{array}{r}-0.33 \\
0.78 \\
-0.18\end{array}$ & $\begin{array}{r}-1.9 \times 10^{6} \\
4.3 \times 10^{8} \\
-3.8 \times 10^{7}\end{array}$ & $\begin{array}{l}9.2 \times 10^{7} \\
7.5 \times 10^{7} \\
1.7 \times 10^{8}\end{array}$ \\
\hline 700 & $\begin{array}{l}1 \\
2 \\
3\end{array}$ & $\begin{array}{r}0.0004-0.002 \\
0.002-0.013 \\
0.013-0.045\end{array}$ & $\begin{array}{r}-0.53 \\
1.03 \\
-0.24\end{array}$ & $\begin{array}{r}-3.2 \times 10^{4} \\
2.7 \times 10^{8} \\
-3.6 \times 10^{6}\end{array}$ & $\begin{array}{l}3.2 \times 10^{7} \\
3.1 \times 10^{7} \\
4.4 \times 10^{7}\end{array}$ \\
\hline 750 & $\begin{array}{l}1 \\
2\end{array}$ & $\begin{array}{l}0.0004-0.0024 \\
0.0024-0.05\end{array}$ & $\begin{array}{r}-0.94 \\
0.40\end{array}$ & $\begin{array}{r}-1.9 \times 10^{3} \\
1.5 \times 10^{7}\end{array}$ & $\begin{array}{l}2.8 \times 10^{7} \\
2.6 \times 10^{7}\end{array}$ \\
\hline 800 & $\begin{array}{l}1 \\
2\end{array}$ & $\begin{array}{l}0.0004-0.0012 \\
0.0012-0.015\end{array}$ & $\begin{array}{r}0.40 \\
-0.52\end{array}$ & $\begin{array}{r}5.6 \times 10^{7} \\
-6.5 \times 10^{4}\end{array}$ & $\begin{array}{l}1.1 \times 10^{7} \\
1.7 \times 10^{7}\end{array}$ \\
\hline 850 & $\begin{array}{l}1 \\
2\end{array}$ & $\begin{array}{c}0.0004-0.0016 \\
0.002-0.025\end{array}$ & $\begin{array}{r}0.55 \\
-0.52\end{array}$ & $\begin{array}{r}1.0 \times 10^{8} \\
-1.1 \times 10^{5}\end{array}$ & $\begin{array}{l}8.3 \times 10^{6} \\
1.5 \times 10^{7}\end{array}$ \\
\hline 900 & $\begin{array}{l}1 \\
2\end{array}$ & $\begin{array}{l}0.0004-0.0028 \\
0.0028-0.015\end{array}$ & $\begin{array}{r}0.40 \\
-0.49\end{array}$ & $\begin{array}{r}1.3 \times 10^{7} \\
-5.7 \times 10^{4}\end{array}$ & $\begin{array}{l}4.4 \times 10^{6} \\
6.6 \times 10^{6}\end{array}$ \\
\hline 950 & $\begin{array}{l}1 \\
2\end{array}$ & $\begin{array}{l}0.0004-0.0012 \\
0.0016-0.009\end{array}$ & $\begin{array}{r}0.34 \\
-1.20\end{array}$ & $\begin{array}{r}1.1 \times 10^{7} \\
-1.3 \times 10^{2}\end{array}$ & $\begin{array}{l}1.3 \times 10^{6} \\
2.8 \times 10^{6}\end{array}$ \\
\hline 1000 & $\begin{array}{l}1 \\
2\end{array}$ & $\begin{array}{l}0.0004-0.0028 \\
0.0032-0.009\end{array}$ & $\begin{array}{r}0.83 \\
-0.99\end{array}$ & $\begin{array}{r}1.9 \times 10^{7} \\
-4.6 \times 10^{2}\end{array}$ & $\begin{array}{l}2.0 \times 10^{6} \\
2.3 \times 10^{6}\end{array}$ \\
\hline 1100 & $\begin{array}{l}1 \\
2\end{array}$ & $\begin{array}{r}0.0004-0.01 \\
0.012-0.05\end{array}$ & $\begin{array}{r}0.57 \\
-0.86\end{array}$ & $\begin{array}{r}1.3 \times 10^{7} \\
-6.6 \times 10^{3}\end{array}$ & $\begin{array}{l}2.0 \times 10^{5} \\
1.5 \times 10^{6}\end{array}$ \\
\hline 1200 & $\begin{array}{l}1 \\
2\end{array}$ & $\begin{array}{r}0.0004-0.02 \\
0.025-0.07\end{array}$ & $\begin{array}{l}0.21 \\
0.73\end{array}$ & $\begin{array}{l}4.4 \times 10^{5} \\
8.9 \times 10^{5}\end{array}$ & $\begin{array}{l}8.1 \times 10^{5} \\
9.5 \times 10^{5}\end{array}$ \\
\hline 1300 & $\begin{array}{l}1 \\
2\end{array}$ & $\begin{array}{l}0.0004-0.0024 \\
0.0028-0.11\end{array}$ & $\begin{array}{l}0.24 \\
0.31\end{array}$ & $\begin{array}{l}9.9 \times 10^{5} \\
7.2 \times 10^{5}\end{array}$ & $\begin{array}{l}4.8 \times 10^{5} \\
6.1 \times 10^{5}\end{array}$ \\
\hline 1400 & 2 & $0.002-0.07$ & 0.34 & $5.6 \times 10^{5}$ & $6.2 \times 10^{5}$ \\
\hline
\end{tabular}




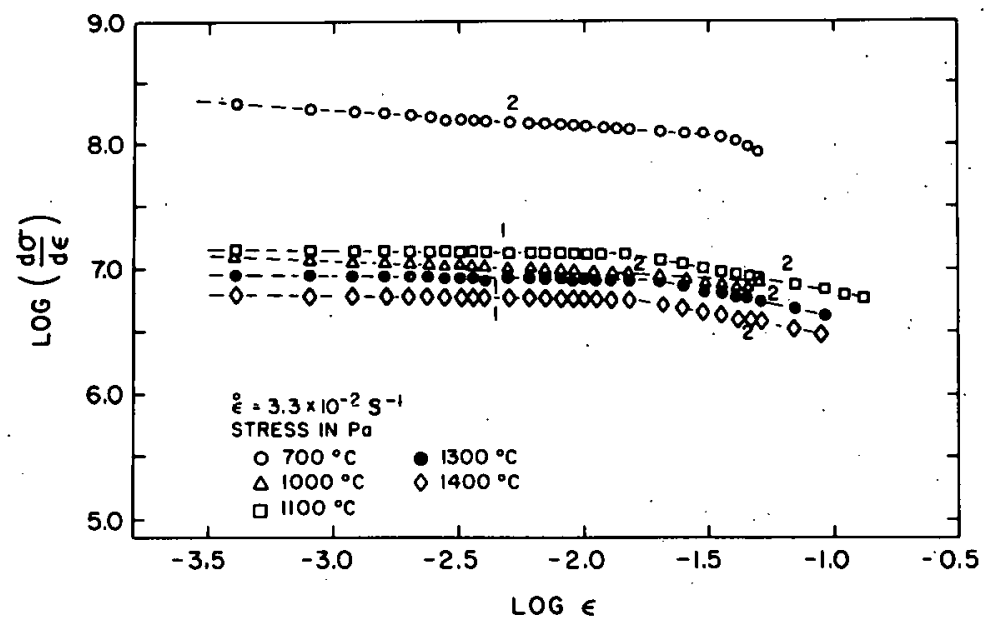

Fig. 28

Plots of $\log (\mathrm{d} \sigma / \mathrm{d} \varepsilon)$ vs $\log \varepsilon$ for Zircaloy -4 Specimens Deformed at $700,1000,1100$, 1300 , and $1400^{\circ} \mathrm{C}$. Neg. No. MSD-61484.

Fig. 29

Work-hardening Exponent as a Function of Temperature for Zircaloy-4 at Four Strain Rates. ANL Neg. No. 306-77-74 Rev. 1.
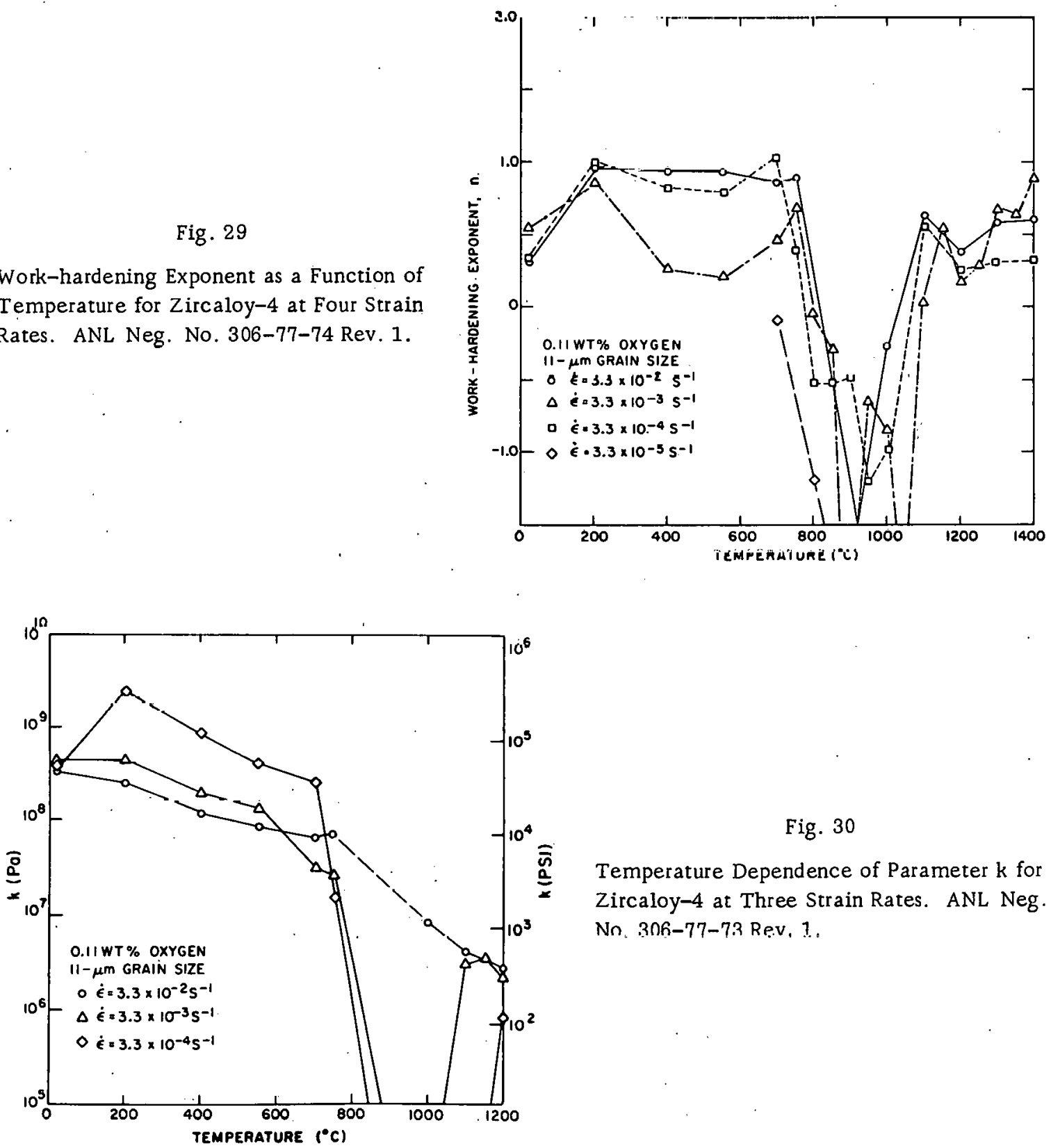

Fig. 30

Temperature Dependence of Parameter $k$ for Zircaloy -4 at Three Strain Rates. ANL Neg. Nn. 3nG-77-7.3 Re.v, 1. 


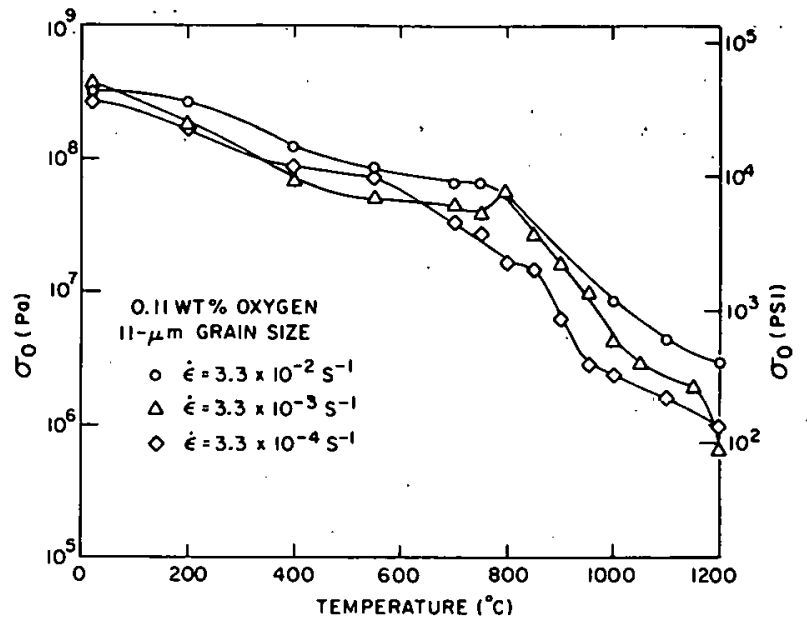

Fig. 31

Variation of $\sigma_{0}$ with Temperature for Zircaloy-4 at Three Strain Rates. ANL Neg. No. 306-77-1.12.

In the $\beta$-phase field (above $1000^{\circ} \mathrm{C}$ ), extensive grain growth during deformation results in positive work-hardening exponents. The variation of $\mathrm{k}$ and $\mathrm{n}$ with temperature is similar ( $\mathrm{Fig} .30$ ). Since the product $\mathrm{kn}$ is proportional to the slope of the stress-strain curve $(\mathrm{d} \sigma / \mathrm{d} \varepsilon)$, the data in Figs. 29 and 30 imply a similar variation of the work-hardening rate with temperature. The parameter $\sigma_{0}$ decreases with an increase in temperature (Fig. 31).

\section{Effect of Texture on the Mechanical Properties}

Figure 32 shows the influence of texture on the temperature dependence of uniform strain of Zircaloy -4 . The $\mathrm{Zircaloy}$ sheet had a texture in which most of the grains had basal poles tilted at $-30^{\circ}$ away from the normal (thickness) direction toward the transverse direction. The longitudinal specimens therefore had more grains favorably oriented for prism slip than the transverse specimens. The diagonal orientation is midway between the longitudinal and transverse orientations. The results in Fig. 32 indicate that, below $800^{\circ} \mathrm{C}$, the uniform strain is somewhat texture-dependent, whereas above this temperature the texture influence appears to be negligible.

Fig. 32

Effect of Texture on Uniform Strain of Zircaloy-4 at Temperatures between Ambient and $1400^{\circ} \mathrm{C}$. ANL Neg. No. 306-76-12 Rev. 1.

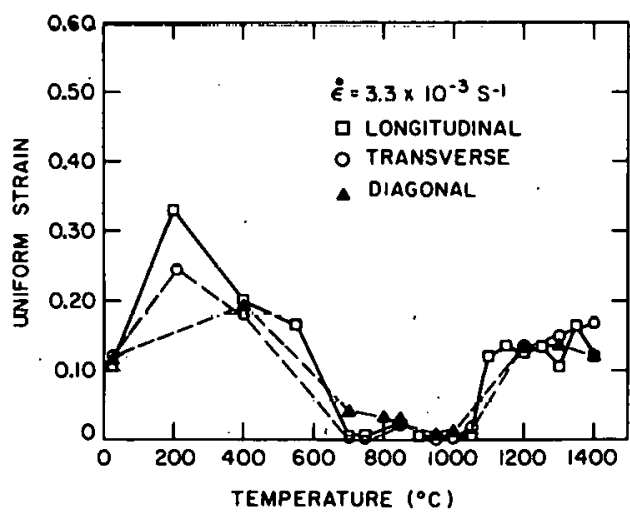

The texture dependence of the total strain of Zircaloy -4 is shown in Fig. 33. The texture effect on the total strain is significant at the low temperature superplastic elongation peak at $850^{\circ} \mathrm{C}$; this implies that prism slip 
plays a role in superplastic deformation at $\dot{\varepsilon}=3.3 \times 10^{-3} \mathrm{~s}^{-1}$. Above $1000^{\circ} \mathrm{C}$, grain growth during tensile testing is considerable; this makes it difficult to deduce the effect of texture on total elongation from the data in Fig. 33 .

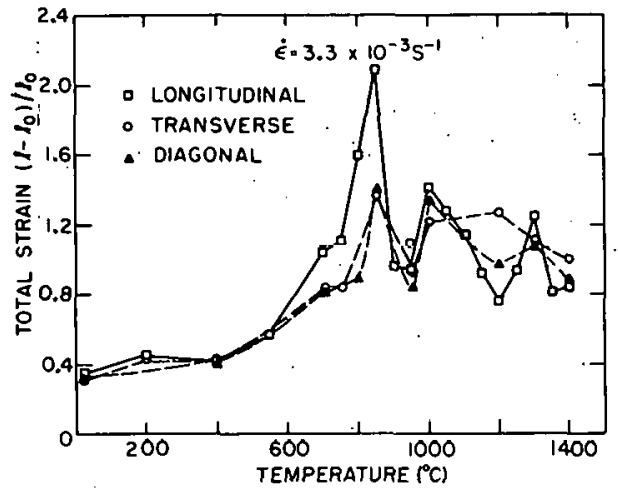

Fig. 33

Influence of Texture on Total Strain of Zircaloy 4 at Temperatures between Ambient and $1400^{\circ} \mathrm{C}$. ANL Neg. No. 306-76-20 Rev. 1.

Figure 34 shows the variation of the ultimate tensile strength with temperature, which appears to be independent of texture at all temperatures. The strain-rate sensitivity is plotted against temperature at $\epsilon=0.02$ for longitudinal and transverse specimens in Fig. 35. For both specimen orientations, the strain-rate sensitivity has a maximum value at $900^{\circ} \mathrm{C}$. Except at $1400^{\circ} \mathrm{C}$, texture does not have a significant effect on strain-rate sensitivity. The difference in the values of strain-rate sensitivity at this temperature may be re lated to variations in the grain growth.

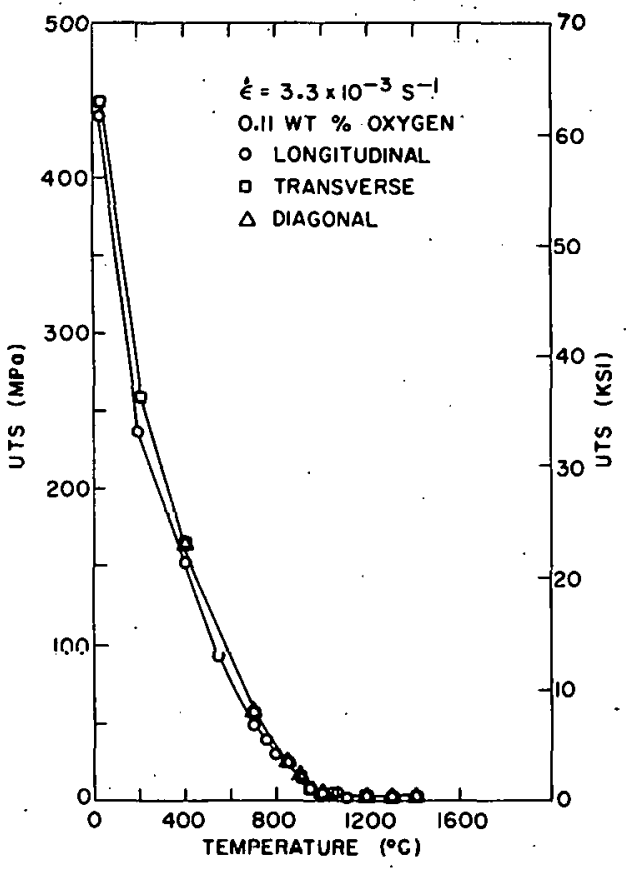

Fig. 34. Temperature Dependence of Ultimate Tensile Strength for Longitudinal. Transverse, and Diagonal Zircaloy-4 Specimens. ANL Neg. No. 306-76-13 Rev. 1.

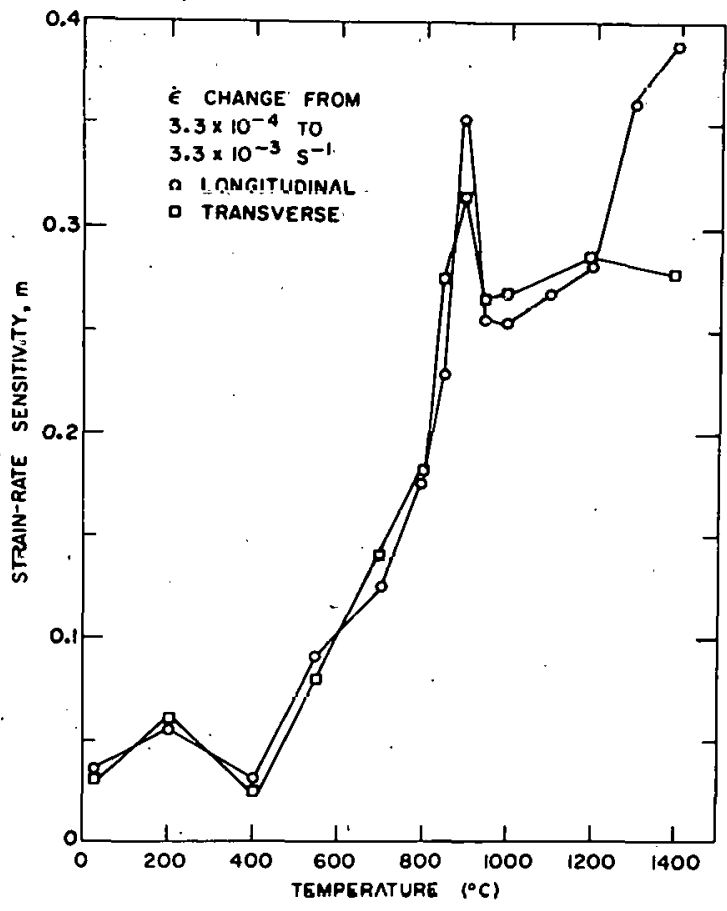

Fig. 35. Strain-rate Sensitivity of Longitudinal and Transverse Zircaloy-4 Specimens as a Function of Temperature. $\varepsilon=0.02$. Neg. No. MSD-62581. 
Figure 36 shows the variation of strain-rate sensitivity with strain for longitudinal and transverse Zircaloy-4 specimens. Although the strain-rate sensitivity of a transverse specimen is always greater than that of a longitudinal specimen, the strain dependence of strain-rate sensitivity is almost identical in both cases.

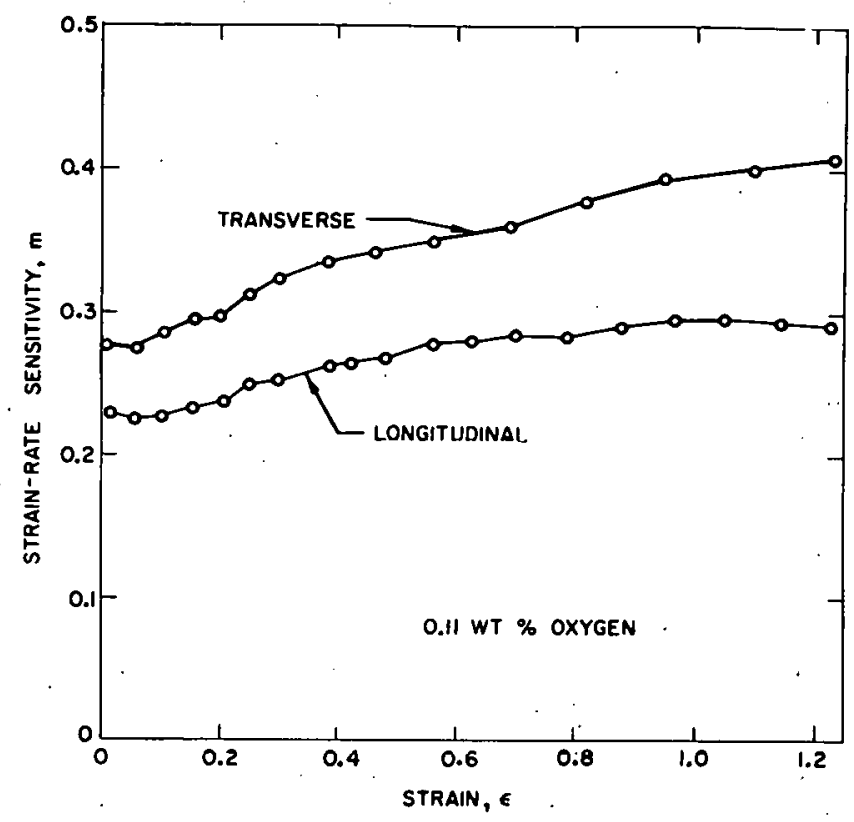

Fig. 36

Strain Depềndence of Strain-rate Sensitivity of $T$ ransverse and Longitudinal Zircaloy-4 Specimens at $850^{\circ} \mathrm{C}$. ANL Neg. No. 306-76-19.

The effect of texture on the work-hardening exponent is shown in Fig. 37 (deduced from the data in Tables VI, VIII, and IX for longitudinal, trans verse and diagonal specimens, respectively). Above $800^{\circ} \mathrm{C}$, the work-hardening rate does not seem to be a strong function of the texture.

Fig. 37

Work-hardening Exponent as a Function of Temperature for Zircaloy-4 Specimens with Three Textures. ANL Neg. No. 306-77-78 Rev. 1.

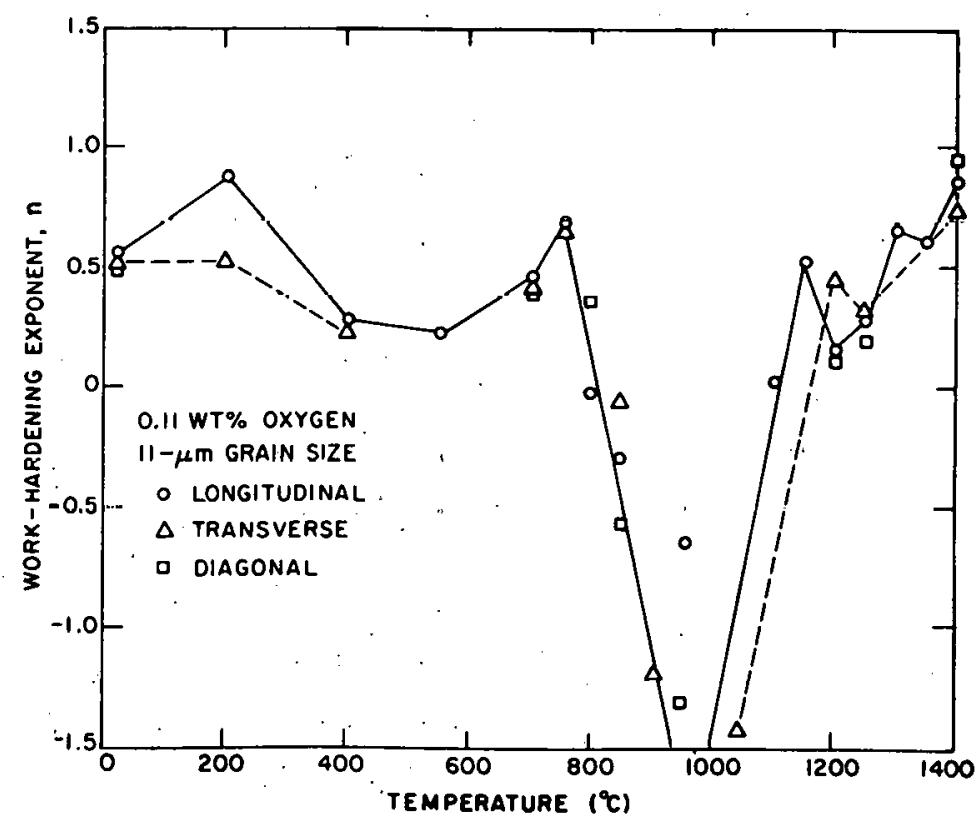


TABLE VIII. Least-squares Work-hardening Constants for Deformation Stages of As-received Transverse Zircaloy-4 Specimens; $\dot{\varepsilon}=3.3 \times 10^{-3} \mathrm{~s}^{-1}$

\begin{tabular}{cccccc}
\hline $\begin{array}{c}\text { Temp, } \\
{ }^{\circ} \mathrm{C}\end{array}$ & $\begin{array}{c}\text { Stage } \\
\text { Number }\end{array}$ & $\begin{array}{c}\text { Strain } \\
\text { Interval }\end{array}$ & $\mathrm{n}$ & $\mathrm{k}, \mathrm{Pa}$ & $\begin{array}{c}\text { Average } \\
\sigma_{0}, \mathrm{~Pa}\end{array}$ \\
\hline 22 & 2 & $0.0004-0.007$ & -0.15 & $-4.5 \times 10^{7}$ & $4.8 \times 10^{8}$ \\
& 3 & $0.008-0.09$ & 0.51 & $4.6 \times 10^{8}$ & $3.4 \times 10^{8}$ \\
200 & 2 & $0.01-0.17$ & 0.50 & $2.6 \times 10^{8}$ & $1.9 \times 10^{8}$ \\
400 & 2 & $0.009-0.17$ & 0.21 & $2.2 \times 10^{8}$ & $3.4 \times 10^{7}$ \\
700 & 2 & $0.01-0.07$ & 0.42 & $3.2 \times 10^{7}$ & $4.7 \times 10^{7}$ \\
750 & 2 & $0.008-0.05$ & 0.67 & $3.0 \times 10^{7}$ & $4.1 \times 10^{7}$ \\
850 & 2 & $0.0004-0.02$ & -0.06 & $-1.3 \times 10^{7}$ & $4.1 \times 10^{7}$ \\
900 & 1 & $0.0004-0.0024$ & 0.2 & $2.9 \times 10^{7}$ & $7.2 \times 10^{6}$ \\
& 2 & $0.0024-0.01$ & -1.2 & $-1.3 \times 10^{3}$ & $1.7 \times 10^{7}$ \\
950 & 2 & $0.0004-0.0028$ & -0.65 & $-3.4 \times 10^{3}$ & $6.3 \times 10^{6}$ \\
1050 & 2 & $0.0004-0.025$ & -0.43 & $-2.5 \times 10^{4}$ & $3.5 \times 10^{6}$ \\
1200 & 1 & $0.0004-0.007$ & -0.06 & $-1.1 \times 10^{6}$ & $3.3 \times 10^{6}$ \\
& 2 & $0.007-0.11$ & 0.47 & $1.8 \times 10^{6}$ & $1.6 \times 10^{6}$ \\
1300 & 2 & $0.0004-0.014$ & 0.91 & $6.4 \times 10^{6}$ & $1.3 \times 10^{6}$ \\
& 2 & $0.015-0.11$ & 0.29 & $1.6 \times 10^{6}$ & $9.4 \times 10^{5}$ \\
1400 & 2 & $0.0004-0.11$ & 0.75 & $1.6 \times 10^{6}$ & $1.1 \times 10^{6}$ \\
\hline
\end{tabular}

TABLE IX. Least-squares Work-hardening Constants for Deformation Stages of As-received Diagonal Zircaloy-4 Specimens; $\dot{\varepsilon}=3.3 \times 10^{-3} \mathrm{~s}^{-1}$

\begin{tabular}{cccccc}
\hline $\begin{array}{c}\text { Temp, } \\
{ }^{\circ} \mathrm{C}\end{array}$ & $\begin{array}{c}\text { Stage } \\
\text { Numbcr }\end{array}$ & $\begin{array}{c}\text { Strain } \\
\text { Interval }\end{array}$ & $\mathrm{n}$ & $\mathrm{k}, \mathrm{F}_{\mathrm{d}}$ & $\begin{array}{c}\text { Average } \\
\sigma_{0}, \mathrm{Pd}_{\mathrm{d}}\end{array}$ \\
\hline 23 & 2 & $0.0004-0.014$ & 0.09 & $2.9 \times 10^{8}$ & $2.0 \times 10^{8}$ \\
& 3 & $0.015-0.09$ & 0.47 & $4.1 \times 10^{8}$ & $3.4 \times 10^{8}$ \\
400 & 2 & $0.0012-0.012$ & 0.88 & $8.1 \times 10^{8}$ & $1.0 \times 10^{8}$ \\
& 3 & $0.013-0.19$ & 0.21 & $2.3 \times 10^{8}$ & $2.3 \times 10^{7}$ \\
700 & 2 & $0.008-0.045$ & 0.36 & $2.7 \times 10^{7}$ & $4.9 \times 10^{1}$ \\
800 & 2 & $0.009-0.025$ & 0.35 & $9.6 \times 10^{6}$ & $2.9 \times 10^{7}$ \\
850 & 1 & $0.0004-0.002$ & 0.64 & $2.3 \times 10^{8}$ & $1.6 \times 10^{7}$ \\
& 2 & $0.002-0.02$ & -0.56 & $-1.2 \times 10^{5}$ & $2.4 \times 10^{7}$ \\
950 & 1 & $0.0004-0.0024$ & 0.18 & $1.5 \times 10^{7}$ & $6.6 \times 10^{5}$ \\
& 2 & $0.0024-0.009$ & -1.31 & $-2.2 \times 10^{2}$ & $6.3 \times 10^{6}$ \\
1000 & 1 & $0.0004-0.0028$ & 0.37 & $1.5 \times 10^{7}$ & $1.9 \times 10^{6}$ \\
& 2 & $0.0028-0.008$ & -2.0 & $-1.7 \times 10^{0}$ & $3.8 \times 10^{6}$ \\
& 3 & $0.008-0.015$ & 0.85 & $3.1 \times 10^{6}$ & $3.8 \times 10^{6}$ \\
1200 & 2 & $0.0004-0.004$ & 0.83 & $4.4 \times 10^{7}$ & $1.1 \times 10^{6}$ \\
& 3 & $0.005-0.11$ & 0.11 & $3.4 \times 10^{6}$ & $-2.7 \times 10^{5}$ \\
1300 & 2 & $0.0004-0.008$ & 0.95 & $8.0 \times 10^{6}$ & $1.3 \times 10^{6}$ \\
& 3 & $0.008-0.09$ & 0.21 & $1.1 \times 10^{6}$ & $9.8 \times 10^{5}$ \\
1400 & 2 & $0.0004-0.09$ & 0.98 & $1.8 \times 10^{6}$ & $1.3 \times 10^{6}$ \\
\hline
\end{tabular}


The results presented in Figs. $32-36$ indicate that texture effects in the deformation of $\mathrm{Zircaloy}$ are significant below $850^{\circ} \mathrm{C}$ and negligible above $1000^{\circ} \mathrm{C}$. Factors that contribute to this type of behavior are (a) the greater symmetry of the body-centered-cubic (bcc) structure of $\beta$-phase Zircaloy $\left(>1000^{\circ} \mathrm{C}\right)$ when compared with the low-temperature $\left(<810^{\circ} \mathrm{C}\right) \alpha$-phase hexagonalclose-packed (hcp) material, (b) the change in the dominant deformation mode of $\alpha$-phase Zircaloy as the temperature is increased ${ }^{31}$ (i.e., below $500^{\circ} \mathrm{C}$, slip occurs on first-order prism planes; at higher temperatures, both basal and pyramidal slip take place), and (c) superplastic deformation at 850 and $1000^{\circ} \mathrm{C}$, where possible grain rotation due to grain-boundary sliding diminishes texture effects.

\section{Fine-grain-size Zircaloy-4}

Figure 38 shows the total strain of $5-\mu \mathrm{m}$ grain-size specimens as a function of deformation temperature at three initial strain rates. Note that, in Fig. 38a, an elongation minimum exists near $400^{\circ} \mathrm{C}$ that is associated with dynamic-strain-aging effects. In Fig. 38b, at all strain $r$ ates, elongation maxima occur at $800-900$ and $1000-1050^{\circ} \mathrm{C}$ separated by a strain minimum near $950^{\circ} \mathrm{C}$. The $\sim 850^{\circ} \mathrm{C}$ total strain peak is highly dependent on strain rate. As the strain rate decreases, the magnitude and temperature of this peak increase. The elongation peak near $1000^{\circ} \mathrm{C}$ does not appear to be a strong function of strain rate. This observation is consistent with the negligible effect of heating rate on the circumferential elongation peak near $1000^{\circ} \mathrm{C}$ in transient-heating burst tests on internally pressurized stress-relieved fine-grain Zircaloy tubes. ${ }^{6}$ The tests on the $5-\mu \mathrm{m}$ grain-size Zircaloy were restricted to temperatures below $1100^{\circ} \mathrm{C}$, since this material showed extraordinary grain growth above $1000^{\circ} \mathrm{C}$.

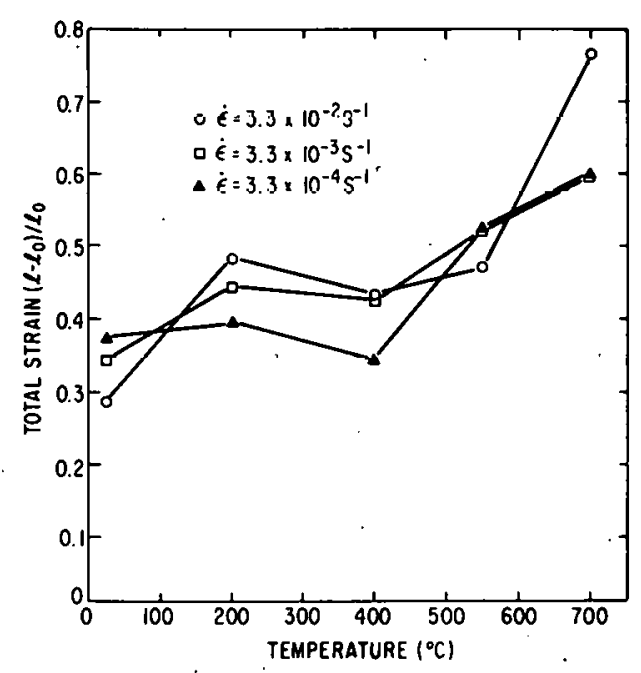

(a)

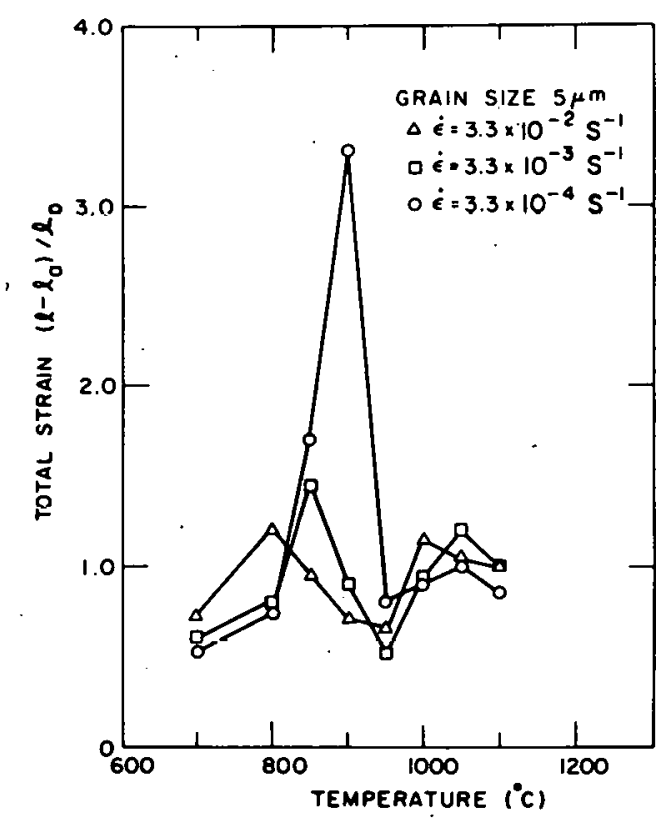

(b)

Fig. 38. Total Strain as a Function of Temperature for 5- $\mu \mathrm{m}$ Grain-size Zircaloy-4 Specimens at Three Strain Rates (a) $23-700^{\circ} \mathrm{C}$ and (b) $700-1100^{\circ} \mathrm{C}$. ANL Neg. No. 306-77-58 Rev. 1 and Neg. Nn. MSR-64145. 
The total elongation-versus-temperature data for the $5-\mu \mathrm{m}$ grainsize material with a width-to-thickness ratio $(w / t)$ of 5 and those for the $11-\mu \mathrm{m}$ grain-size material $(w / t=10)$ in Sec. IV.A.l are consistent and imply that grain-boundary sliding at the $\alpha-\beta$ interface is an important factor in superplas tic deformation of Zircaloy between 850 and $900^{\circ} \mathrm{C}$. The shift in the temperature of the superplastic elongation maximum from 850 to $900^{\circ} \mathrm{C}$ as the grain size decreases from 11 to $5 \mu \mathrm{m}$ can be rationalized in terms of the increase in the $\alpha-\alpha$ grain-boundary area. To achieve a grain-boundary film of $\beta$ phase, the fine-grain material must have a larger volume fraction of $\beta$ phase, which is present at the higher temperature. The increase in the magnitude of the superplastic elongation maximum at lower strain rates is consistent with the greater importance of grain-boundary sliding under these conditions.

Figure 39 shows the effect of temperature on the strain-rate sensitivity of fine-grain Zircaloy-4. The strain-rate sensitivity shows a peak at $900^{\circ} \mathrm{C}$. These data are similar to the results presented earlier (Fig. 35) for the $11-\mu \mathrm{m}$ grain-size material. However, a comparison of the two sets of data at $900^{\circ} \mathrm{C}$ reveals that the strain-rate sensitivity increases from 0.35 to 0.60 as the grain size decreases from 11 to $5 \mu \mathrm{m}$.

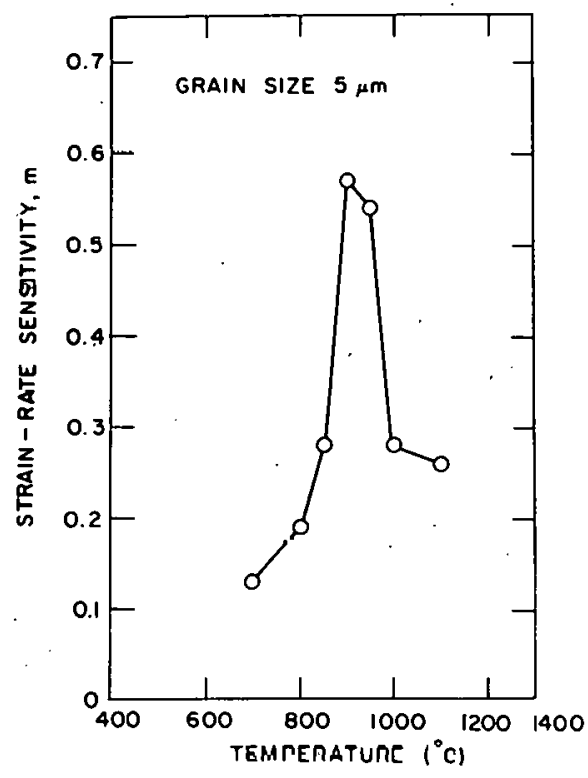

Fig. 39

Strain-rate Sensitivity of Fine-grain Zircaloy-4 as a Function of Temperature. Strain-rate change from $2.6 \times 10^{-4}$ to $2.6 \times 10^{-3} \mathrm{~s}^{-1}$. $\varepsilon=$ 0.02 . Neg. No. MSD-63156.

Figure 40 shows the effect of strain rate on the total and uniform strain of the 5- $\mu \mathrm{m}$ grain-size material at $900^{\circ} \mathrm{C}$. Both the uniform and total strains increase as the strain rate decreases. The large uniform strain, i.e., $\sim 0.5$ at a strain rate of $2.6 \times 10^{-5} \mathrm{~s}^{-1}$, may be due to the grain growth observed at the lower strain rates. Figure 41 shows that the strain-rate sensitivity also increases as the strain rate decreases.

The work-hardening characteristics of fine-grain Zircaloy at three strain rates are presented in Tables X-XII and Fig. 42. Similar to the $11-\mu \mathrm{m}$ grain-size material, the work-hardening exponent (Fig. 42) is positive below $600^{\circ} \mathrm{C}$ and negative for the temperature interval $\sim 700-1000^{\circ} \mathrm{C}$. 


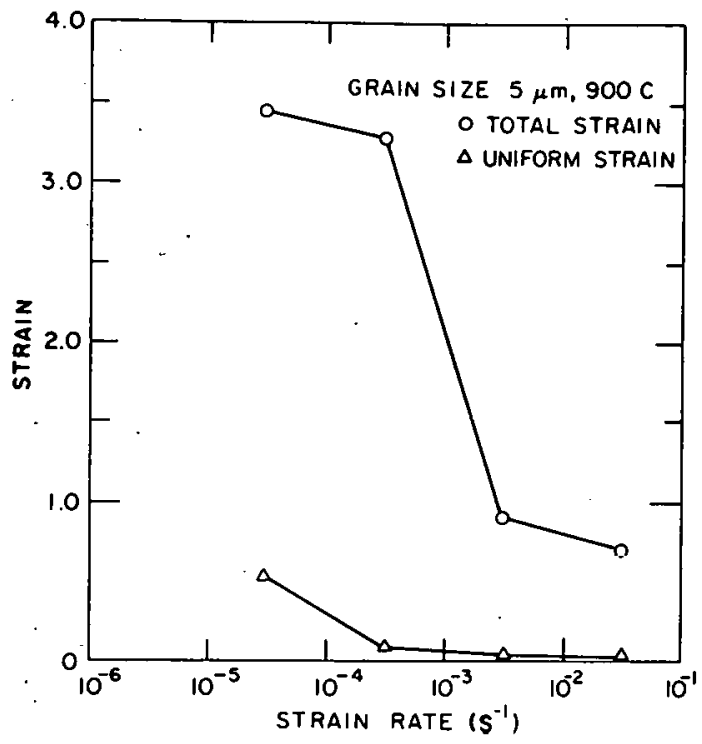

Fig. 40. Effect of Strain Rate on Total and Uniform Strain of Zircaloy-4 at $900^{\circ} \mathrm{C}$. Neg. No. MSD 63139.

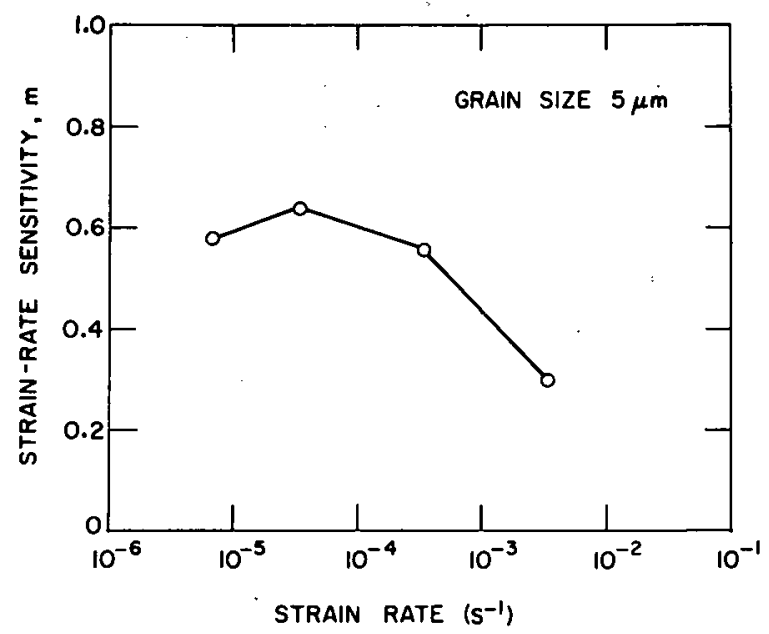

Fig. 41. Strain-rate Dependence of Strainrate Sensitivity of Zircaloy -4 at $900^{\circ} \mathrm{C}$. Neg. No. MSD 63140 .

TABLE X. Least-squares Work-hardening Constants for Deformation Stages of $5-\mu \mathrm{m}$ Grain-size Zircaloy-4; $\dot{\varepsilon}=3.3 \times 10^{-2} \mathrm{~s}^{-1}$

\begin{tabular}{rccccc}
\hline $\begin{array}{c}\text { Temp, } \\
{ }^{\circ} \mathrm{C}\end{array}$ & $\begin{array}{c}\text { Stage } \\
\text { Number }\end{array}$ & $\begin{array}{c}\text { Strain } \\
\text { Interval }\end{array}$ & $\mathrm{n}$ & $\mathrm{k}, \mathrm{Pa}$ & $\begin{array}{c}\text { Average } \\
\sigma_{0}, \mathrm{~Pa}\end{array}$ \\
\hline 25 & 2 & $0.0004-0.09$ & 0.57 & $5.2 \times 10^{8}$ & $4.2 \times 10^{8}$ \\
200 & 2 & $0.0002-0.13$ & 0.34 & $2.8 \times 10^{8}$ & $1.8 \times 10^{8}$ \\
400 & 2 & $0.02-0.17$ & 0.36 & $2.5 \times 10^{8}$ & $1.2 \times 10^{8}$ \\
550 & 2 & $0.013-0.15$ & 0.28 & $1.7 \times 10^{8}$ & $8.3 \times 10^{7}$ \\
800 & 2 & $0.0004-0.0016$ & -0.46 & $-2.1 \times 10^{5}$ & $6.5 \times 10^{7}$ \\
850 & 2 & $0.0004-0.005$ & -0.57 & $-9.4 \times 10^{1}$ & $4.5 \times 10^{7}$ \\
900 & 1 & $0.0004-0.002$ & 0.04 & $5.9 \times 10^{7}$ & $-1.2 \times 10^{7}$ \\
& 2 & $0.0024-0.004$ & -3.3 & $-9.8 \times 10^{-4}$ & $3.4 \times 10^{7}$ \\
950 & 2 & $0.0004-0.0012$ & -0.76 & $-5.1 \times 10^{3}$ & $2.4 \times 10^{7}$ \\
1000 & 1 & $0.0004-0.0016$ & -0.19 & $-4.4 \times 10^{4}$ & $8.6 \times 10^{6}$ \\
1050 & 1 & $0.0004-0.0032$ & 1.0 & $2.5 \times 10^{8}$ & $5.1 \times 10^{6}$ \\
. & 2 & $0.004-0.011$ & -1.2 & $-5.3 \times 10^{2}$ & $6.2 \times 10^{6}$ \\
& 3 & $0.012-0.09$ & 0.73 & $5.7 \times 10^{6}$ & $5.8 \times 10^{6}$ \\
\hline
\end{tabular}


TABLE XI. Least-squares Work-hardening Constants for Deformation Stages of $5-\mu \mathrm{m}$ Grain-size Zircaloy $-4 ; \dot{\varepsilon}=3.3 \times 10^{-3} \mathrm{~s}^{-1}$

\begin{tabular}{|c|c|c|c|c|c|}
\hline $\begin{array}{l}\text { Temp, } \\
{ }^{\circ} \mathrm{C}\end{array}$ & $\begin{array}{l}\text { Stage } \\
\text { Number }\end{array}$ & $\begin{array}{l}\text { Strain } \\
\text { Interval }\end{array}$ & $\mathrm{n}$ & $\mathrm{k}, \mathrm{Pa}$ & $\begin{array}{c}\text { Average } \\
\sigma_{0}, \mathrm{~Pa}\end{array}$ \\
\hline 25 & $\begin{array}{l}1 \\
2\end{array}$ & $\begin{array}{c}0.0004-0.004 \\
0.005-0.15\end{array}$ & $\begin{array}{l}0.41 \\
0.64\end{array}$ & $\begin{array}{l}3.6 \times 10^{8} \\
5.6 \times 10^{8}\end{array}$ & $\begin{array}{l}3.8 \times 10^{8} \\
4.0 \times 10^{8}\end{array}$ \\
\hline 200 & 2 & $0.025-0.25$ & 0.62 & $5.0 \times 10^{8}$ & $2.0 \times 10^{8}$ \\
\hline 400 & 2 & $0.015-0.19$ & 0.50 & $3.0 \times 10^{8}$ & $1.3 \times 10^{8}$ \\
\hline 550 & $\begin{array}{l}1 \\
2\end{array}$ & $\begin{array}{l}0.0004-0.0032 \\
0.0036-0.13\end{array}$ & $\begin{array}{r}-0.32 \\
0.72\end{array}$ & $\begin{array}{r}-1.5 \times 10^{6} \\
1.6 \times 10^{8}\end{array}$ & $\begin{array}{l}1.3 \times 10^{8} \\
1.2 \times 10^{8}\end{array}$ \\
\hline 700 & 2 & $0.012-0.05$ & 1.2 & $9.8 \times 10^{7}$ & $5.3 \times 10^{7}$ \\
\hline 800 & 2 & $0.0004-0.002$ & -0.77 & $-7.4 \times 10^{3}$ & $3.9 \times 10^{7}$ \\
\hline 850 & 2 & $0.0004-0.0024$ & -0.96 & $-2.0 \times 10^{3}$ & $2.6 \times 10^{7}$ \\
\hline 900 & 2 & $0.0004-0.004$ & 0.34 & $3.2 \times 10^{7}$ & $1.3 \times 10^{7}$ \\
\hline 950 & 2 & $0.005-0.012$ & -1.9 & $-3.4 \times 10^{1}$ & $1.8 \times 10^{7}$ \\
\hline .1000 & 2 & $0.0004-0.0024$ & -0.13 & $-1.6 \times 10^{5}$ & $4.9 \times 10^{6}$ \\
\hline 1050 & 1 & $\begin{array}{l}0.0004-0.0032 \\
0.0036-0.05\end{array}$ & $\begin{array}{r}-0.42 \\
0.92\end{array}$ & $\begin{array}{r}-6.9 \times 10^{3} \\
3.3 \times 10^{6}\end{array}$ & $\begin{array}{l}3.4 \times 10^{6} \\
3.3 \times 10^{6}\end{array}$ \\
\hline 1100 & $\begin{array}{l}1 \\
2\end{array}$ & $\begin{array}{c}0.0004-0.012 \\
0.013-0.07\end{array}$ & $\begin{array}{l}0.01 \\
0.94\end{array}$ & $\begin{array}{l}5.8 \times 10^{6} \\
4.1 \times 10^{6}\end{array}$ & $\begin{array}{r}-2.7 \times 10^{6} \\
2.8 \times 10^{6}\end{array}$ \\
\hline
\end{tabular}

TABLE XII. Least-squares Work-hardening Constants for Deformation Stage $s$ of $5-\mu \mathrm{m}$ Grain-size Zircaloy $-4 ; \dot{\epsilon}=3.3 \times 10^{-4} \mathrm{~s}^{-1}$

\begin{tabular}{rccccc}
\hline $\begin{array}{c}\text { Temp } \\
{ }^{\circ} \mathrm{C}\end{array}$ & $\begin{array}{c}\text { Stage } \\
\text { Number }\end{array}$ & $\begin{array}{c}\text { Strain } \\
\text { Interval }\end{array}$ & $\mathrm{n}$ & $\mathrm{k}, \mathrm{Pa}$ & $\begin{array}{c}\text { Average } \\
\sigma_{0}, \mathrm{~Pa}\end{array}$ \\
\hline 25 & 2 & $0.011-0.13$ & 0.53 & $5.2 \times 10^{8}$ & $3.4 \times 10^{8}$ \\
200 & 2 & $0.025-0.15$ & $\sim 0$ & $1.6 \times 10^{10}$ & $-1.5 \times 10^{10}$ \\
400 & 2 & $0.013-0.15$ & 0.41 & $2.7 \times 10^{8}$ & $1.3 \times 10^{8}$ \\
700 & 2 & $0.0004-0.0028$ & -0.54 & $-4.3 \times 10^{4}$ & $1.8 \times 10^{7}$ \\
800 & 1 & $0.0004-0.006$ & -0.23 & $-3.6 \times 10^{5}$ & $2.2 \times 10^{7}$ \\
850 & 1 & $0.0004-0.002$ & 0.55 & $1.1 \times 10^{8}$ & $7.5 \times 10^{6}$ \\
& 2 & $0.0024-0.013$ & -1.1 & $-1.5 \times 10^{3}$ & $1.3 \times 10^{7}$ \\
900 & 1 & $0.0004-0.0024$ & 0.81 & $1.4 \times 10^{8}$ & $2.6 \times 10^{6}$ \\
& 2 & $0.0028-0.09$ & -0.16 & $-2.3 \times 10^{6}$ & $9.9 \times 10^{6}$ \\
950 & 1 & $0.0004-0.045$ & -0.11 & $-1.8 \times 10^{6}$ & $7.6 \times 10^{6}$ \\
1000 & 1 & 0.00010 .002 & -0.35 & $-7.8 \times 10^{3}$ & $2.4 \times 10^{6}$ \\
& 2 & $0.0024-0.007$ & 0.47 & $9.6 \times 10^{5}$ & $2.3 \times 10^{6}$ \\
1050 & 1 & $0.0004-0.004$ & 0.63 & $1.6 \times 10^{6}$ & $1.8 \times 10^{6}$ \\
1100 & 1 & $0.0004-0.004$ & 0.56 & $8.2 \times 10^{6}$ & $1.1 \times 10^{6}$ \\
& 2 & $0.005-0.07$ & -0.03 & $-4.7 \times 10^{6}$ & $7.0 \times 10^{6}$ \\
\hline
\end{tabular}




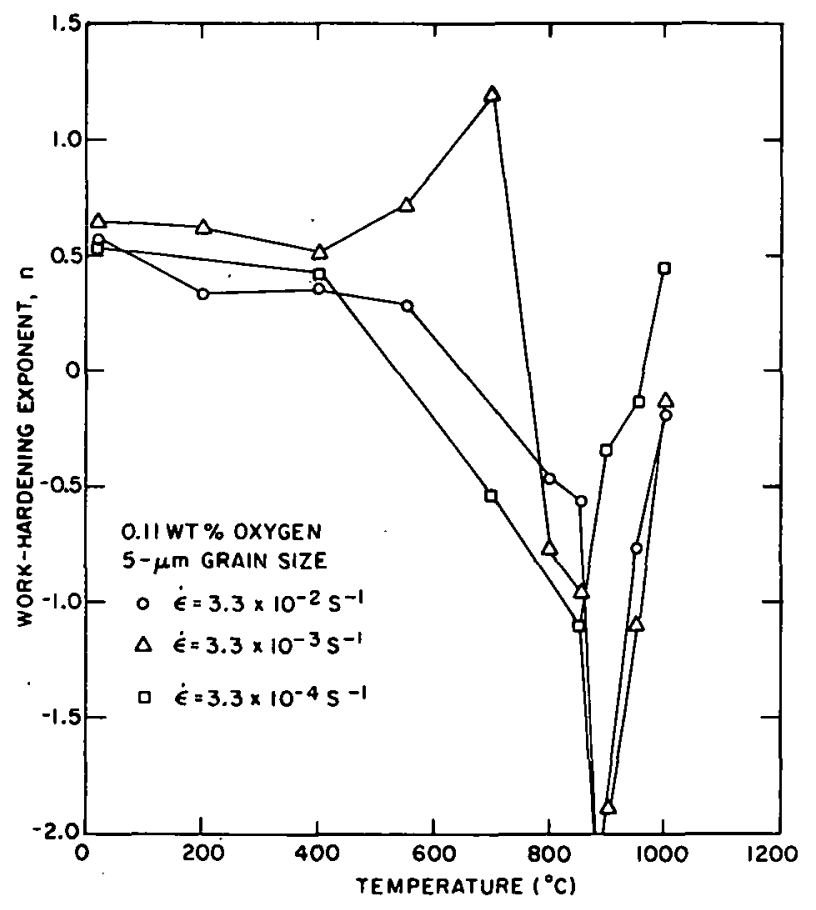

Fig. 42

Work-hardening Exponent of Fine-grainsize Zircaloy-4 as a Function of Temperature at Three Strain Rates. ANL Neg. No. 306-77-59 Rev, 1.

\section{Influence of Specimen Geometry}

Since the total elongation observed in a tension test is a function of the gauge length-to-width $(l / w)$ ratio of the specimen, the ASTM standard tensile specimen has a constant $\ell / w$ ratio of four. Although the ASTM standard does not restrict the thickness of the sheet tensile sample, the $\mathrm{w} / \mathrm{t}$ ratio has a significant influence on the ductility of Zircaloy. Figure 43 shows the effect of the $\mathrm{w} / \mathrm{t}$ ratio on the strain-rate dependence of the strain-rate sensitivity. At low strain rates $\left(<10^{-5} \mathrm{~s}^{-1}\right)$, a lower $\mathrm{w} / \mathrm{t}$ ratio decreases the value of $\mathrm{m}$ significantly. Since the total strain measured during superplastic tensile deformation is a strong function of the strain-rate sensitivity, the value of $w / t$ influences the superplastic ductility.

Fig. 43

Effect of Width-to-Thickness Ratio (w/t) of Tensile Specimen on Strain-rate Dependence of Strain-rate Sensitivity of Zircaluy -4 at $850^{\circ} \mathrm{C}$. Strain-rate cliange from $10^{-4}$ to $10^{-3} \mathrm{~s}^{-1}$. $\varepsilon=0.02$. Neg. Nu. MSD-03141.

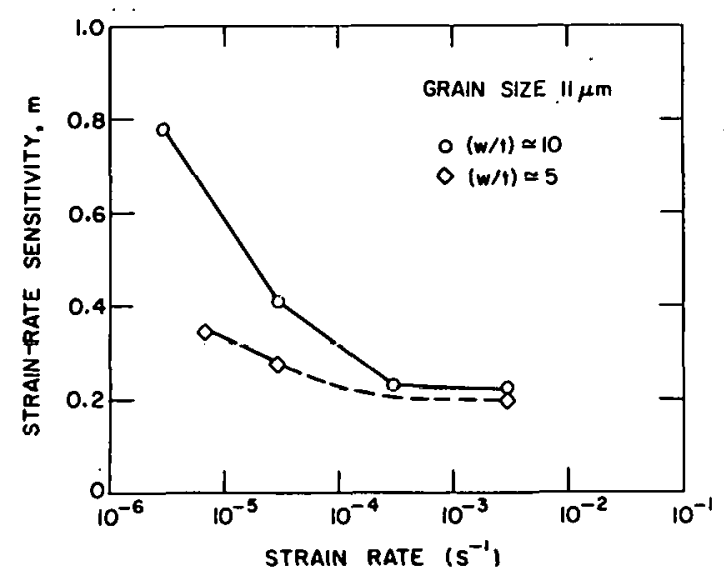

The strain-rate dependence of the total strain is shown in Figs. 44 and 45 for Zircaloy -4 with several grain sizes at two values of $w / t$. A comparison of the $11-\mu \mathrm{m}$ grain-size curve in both figures indicates that $w / t$ has a 
strong influence on the total strain at intermediate strain rates $\left(10^{-5}\right.$ to $\left.10^{-3} \mathrm{~s}^{-1}\right)$. These results directly show that the value of $\mathrm{w} / \mathrm{t}$ influences the extent of superplastic ductility.

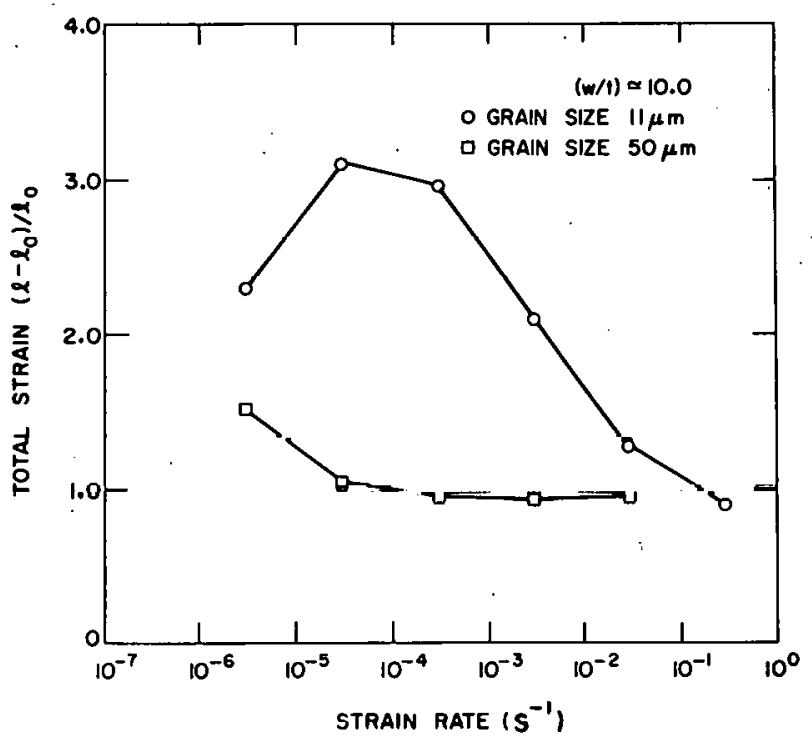

Fig. 44

Dependence of Total Strain on Strain Rate for 11- and 50- $\mu \mathrm{m}$ Grain-size Zircaloy-4 Specimons at $850^{\circ} \mathrm{C}$. Nicg. No. MED 60163 .

Fig. 45

Strain-rate Dependence of Total Strain of 5- and 11- $\mu \mathrm{m}$ Grain-size Lircaloy-4 Specimens at $850^{\circ} \mathrm{C}$. Neg. No. MSD'-63154.

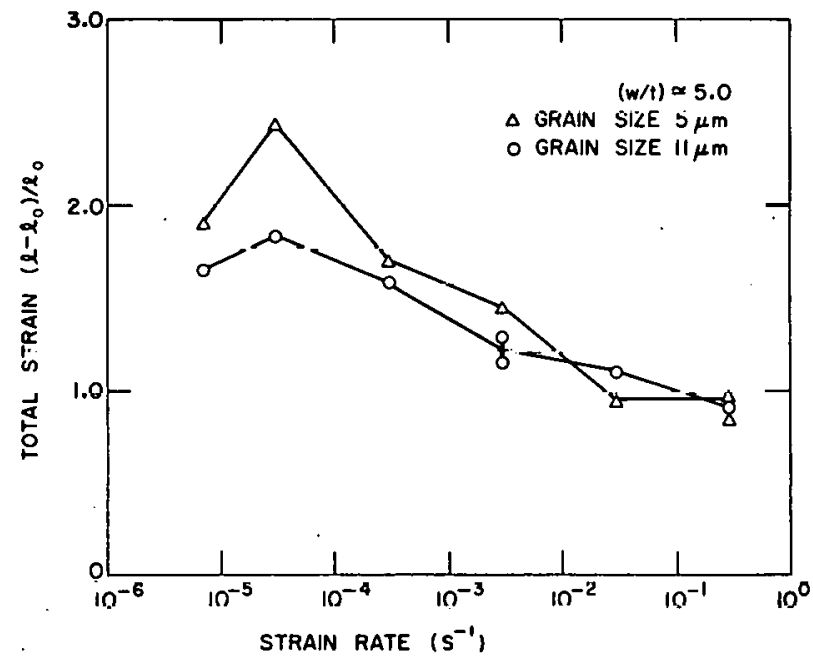




\section{Effect of Grain Size on Tensile Properties}

As shown in Figs. 44 and 45, a larger grain size results in a smaller total elongation for Zircaloy-4, particularly at the intermediate strain

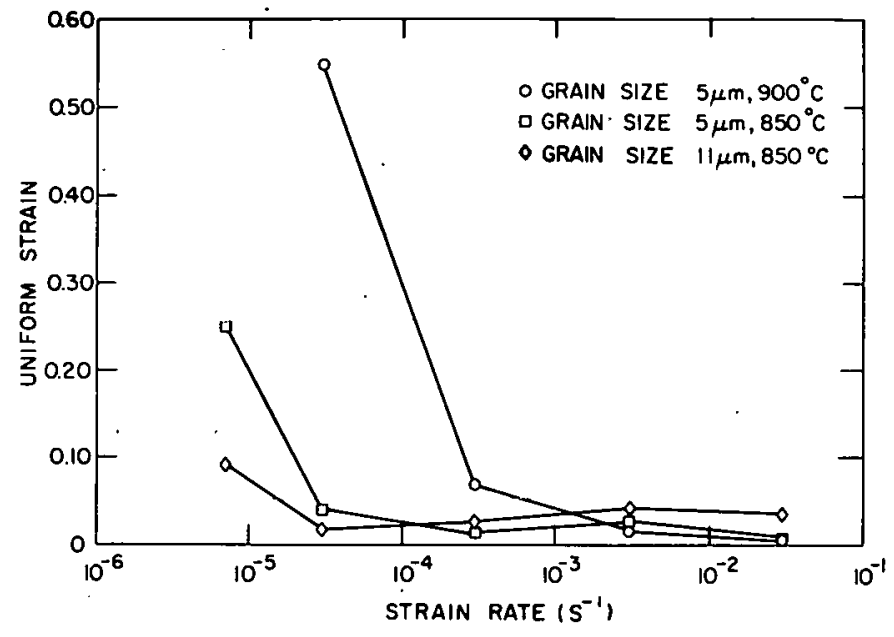

Fig. 46. Variation of Uniform Strain with Strain Rate for 5- and 11- $\mu \mathrm{m}$ Grain-size Zircaloy-4. Neg. No. MSD-63138. rates $\left(10^{-5}-10^{-3} \mathrm{~s}^{-1}\right.$, Fig. 44) at $850^{\circ} \mathrm{C}$ where superplastic ductilities are observed. Figure 46 shows the effect of grain size on the strain-rate dependence of the uniform strain of Zircaloy-4. At $850^{\circ} \mathrm{C}$, as the strain rate decreases below $10^{-4} \mathrm{~s}^{-1}$, the uniform strain increases for both grain sizes. The increase in uniform strain at $900^{\circ} \mathrm{C}$ for the $5-\mu \mathrm{m}$ grainsize material is even moredramatic and occurs at strain rates below $10^{-3} \mathrm{~s}^{-1}$. The high uniform strain at low strain rates is related to the substantial grain growth that occurs during deformation. When grain-boundary sliding contributes significantly to the overall defor-

mation, as is the case at these low strain rates, grain growth results in a hardening effect that increases the uniform strain. The larger uniform strain at the strain rate of $6.6 \times 10^{-6} \mathrm{~s}^{-1}$ for $5-\mu \mathrm{m}$ grain-size material at $850^{\circ} \mathrm{C} \mathrm{can}$ be rationalized in terms of a greater contribution of grain-boundary sliding for the smaller grain size.

Figure 47 shows the variation of the yield stress with grain size for Zircaloy -4 at $850^{\circ} \mathrm{C}$. As the strain rate decreases from $10^{-2}$ to $10^{-6} \mathrm{~s}^{-1}$, the slope of the curves changes from small negative to large positive values.

Fig. 47

Yield Stress as a Function of Grain Size for Zircaloy 4 at $850^{\circ} \mathrm{C}$. Neg. No. MSD $\rightarrow 63155$.

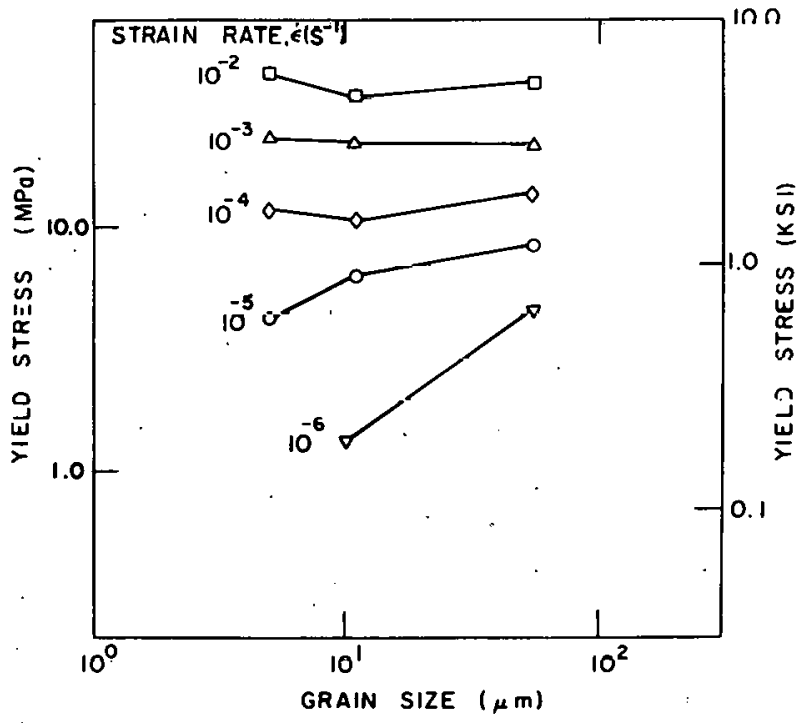


At high strain rates $\left(>10^{-4} \mathrm{~s}^{-1}\right)$, transgranular deformation due to dislocation glide and creep is important. This case is similar to deformation at lower temperatures $\left(\mathrm{T}<0.4 \mathrm{~T}_{\mathrm{m}}\right.$, where $\mathrm{T}_{\mathrm{m}}$ is the absolute melting temperature), where the finer-grain-size material exhibits a higher flow stress than the coarse-grain material. At low temperatures the well-known Petch effect is observed, in which the slope of the logarithmic stress-grain size curve has a value of -0.5 . In Fig. 47, as the strain rate decreases below $10^{-5} \mathrm{~s}^{-1}$, grainboundary sliding becomes the predominant deformation mechanism and the slopes of the curves assume positive values that are consistent with viscous deformation at the grain boundaries:

\section{Influence of Microstructural State}

a. Phase Distribution. The effect of hold time at high temperature prior to deformation on the tensile elongation of Zircaloy illustrates the influence of the microstructural state on the tensile properties.

The experimental procedure for determining the tensile properties of Zircaloy in the present program involved a short (0.6-ks) hold time at the various test temperatures before the deformation was started. Figure 48 shows the effect of increasing the hold time from 0.6 to $7.2 \mathrm{ks}$ before deformation on the total elongation of $\mathrm{Zircaloy}-4$ specimens for temperatures between 850 and $1000^{\circ} \mathrm{C}$. The additional hold time does not have a significant effect on the total strain at 900 and $950^{\circ} \mathrm{C}$; however, the strain decreases considerably at 850 and $1000^{\circ} \mathrm{C}$. The decrease in the total elongation at $1000^{\circ} \mathrm{C}$ is probably due to the grain coarsening that becomes significant at this temperature. At lower temperatures, grain growth is less important.

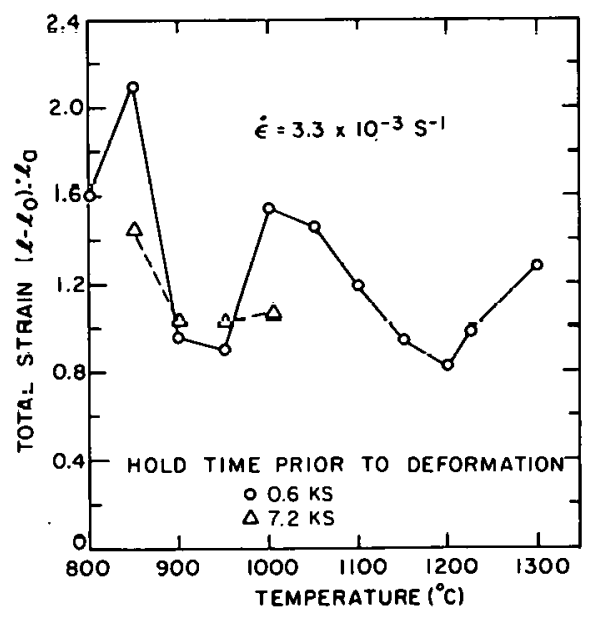

Fig. 48

Effect of Hold Time hefore Deformation on Total Strain of Żircaloy-4. ÁNi Neg. No. 306-75-200 Rev. 2.

Metallographic examination of the specimens tested at $850^{\circ} \mathrm{C}$ revealed that the $\alpha$ grains in the deformed region of the specimen with a $0.6-\mathrm{ks}$ hold time were completely equiaxed, whereas the grains in the specimen with the $7.2-\mathrm{ks}$ hold time were elongated. 
The dependence of the ductility on hold time is related to the microstructural changes that occur in the material. To examine the microstructures that exist at high temperature, specimens were oil-quenched from $850^{\circ} \mathrm{C}$ after 0.6 - and 7.2 -ks hold times. For a 0.6 -ks hold time (Fig. 49), the microstructure consists of a large volume fraction of $\alpha$-phase grains with a small volume fraction of $\beta$ phase distributed both at the $\alpha$-grain boundaries and within the $\alpha$ grains. During the $7.2 \mathrm{ks}$ hold time, oxygen redistribution occurs and the thickness of the $\beta$-phase film at the $\alpha$-grain boundaries increases (Fig. 50).

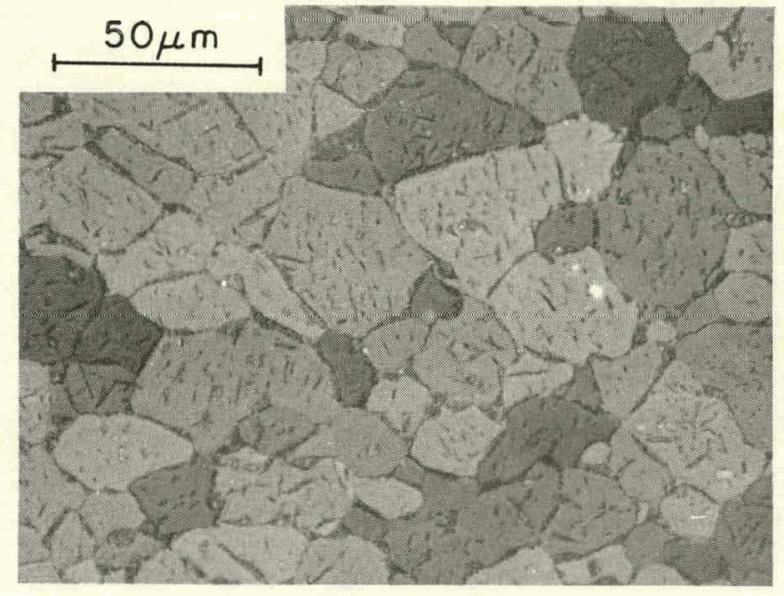

Fig. 49. Microstructure of a Zircaloy-4 Specimen Oil-quenched from $850^{\circ} \mathrm{C}$ after 0.6 -ks Hold Time. A small volume fraction of $\beta$ phase is distributed at the $\alpha$-grain boundaries and within the $\alpha$ grains. Neg. No. MSD-63406.

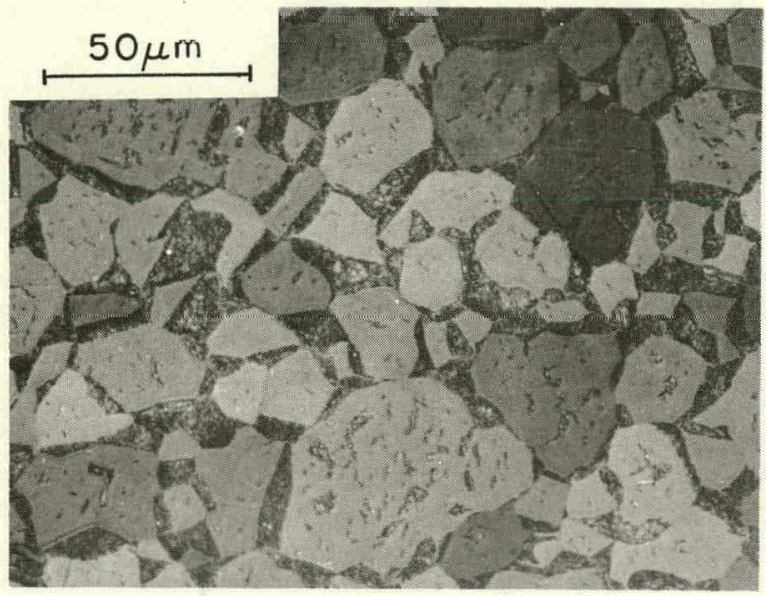

Fig. 50. Microstructure of a Zircaloy-4 Specimen Oil-quenched from $850^{\circ} \mathrm{C}$ after $7.2-\mathrm{ks}$ Hold Time. The volume fraction of $\beta$ phase concentrated at the $\alpha$-grain boundaries is greater than that in Fig. 49 . Neg. No. MSD-63404.

Apparently the fine $\beta$-phase film at the $\alpha$-grain boundaries in Fig. 49 was more conducive to grain-boundary sliding and hence to superplastic ductility. To determine the role of $\beta$ phase at the $\alpha$-grain boundaries on grain-boundary sliding, we conducted the following experiment. The as received Zircaloy was prestrained to $\epsilon=0.003$ at $700^{\circ} \mathrm{C}$, heated to $850^{\circ} \mathrm{C}$, held for $7.2 \mathrm{ks}$, and then strained to fracture. As a result of the small prestrain at $700^{\circ} \mathrm{C}$, the large total-strain behavior was reestablished, even after the $7.2-\mathrm{ks}$ hold time; i.e., the specimen fractured at $\epsilon=2.00$. Prestraining at $700^{\circ} \mathrm{C}$ introduced additional defects and dislocations in the structure. When this specimen was heated to the two-phase region, $\beta$ phase precipitated on a finer scale as a result of the additional nucleation sites. During the 7.2-ks hold time at $850^{\circ} \mathrm{C}, \beta$-phase coalescence (and also that of the $\chi$ phase present)* was difficult because of the interaction between $\beta$ phase and the additional

*The $X$ phase exists below $870^{\circ} \mathrm{C}^{32}$ and has the approximate composition of 5-9 wt \% Fe, 0-2 wt \% Cr, 1.5 wt $\% \mathrm{Sn}$, and the balance is zirconium. 33 As-received Zircaloy in the cold-rolled and the annealed condition contains a small volume fraction of randomly distributed $\sim 1-\mu \mathrm{m} X$-phase particles. 
defects introduced during prestraining at $700^{\circ} \mathrm{C}$. Since the $\beta$-phase film thickness at the $\alpha$-grain boundary remained small, this specimen exhibited superplastic deformation similar to the specimen with the $0.6-\mathrm{ks}$ hold time at $850^{\circ} \mathrm{C}$ without low-temperature prestrain.

b. $\alpha$-phase Morphology. The morphology of transformed $\beta$ phase ( $\alpha^{\prime}$ phase) strongly depends on the cooling rate through the two-phase region ( 980-80 $\left.5^{\circ} \mathrm{C}\right)$. The types of transformed $\beta$-phase microstructure associated with the various approximate cooling rates are as follows: elongated wide grains $\left(0.1^{\circ} \mathrm{C} / \mathrm{s}, \mathrm{Fig}\right.$. 51), parallel-plate structure $\left(2^{\circ} \mathrm{C} / \mathrm{s}, \mathrm{Fig} .52\right)$, basketweave structure $\left(\sim 500^{\circ} \mathrm{C} / \mathrm{s}\right.$, Fig. 53$)$, and martensitic structure $\left(\sim 10,000^{\circ} \mathrm{C} / \mathrm{s}\right.$, Fig. 54$)$. At intermediate cooling rates, i.e., $\sim 100^{\circ} \mathrm{C} / \mathrm{s}$, the microstructure of trans formed $\beta$ phase consists of a mixture of the parallel-plate and basketweave structures. Hor a hypothetical LULA situation in an LWR, the cladding microstructure during the heating transient is equiaxed, and if the maximum temperature exceeds $1000^{\circ} \mathrm{C}$, the $\beta$ phase transforms during cooling to either the parallel-plate or basketweave structure.

Figure 55 shows the effect of $\alpha$-phase morphology on the engineering stress-strain behavior of Zircaloy-4 at $400^{\circ} \mathrm{C}$. Without the hightemperature anneals at 850 and $1000^{\circ} \mathrm{C}$, the microstructure of the as-received material is completely equiaxed $\alpha$. This material has an ultimate tensile strength of $\sim 150 \mathrm{MPa}$ and a total strain of 0.42 . After a $0.6-\mathrm{ks}$ anneal at $850^{\circ} \mathrm{C}$ and cooling to $400^{\circ} \mathrm{C}$, the structure will contain $\sim 10 \% \alpha$ in the transformed

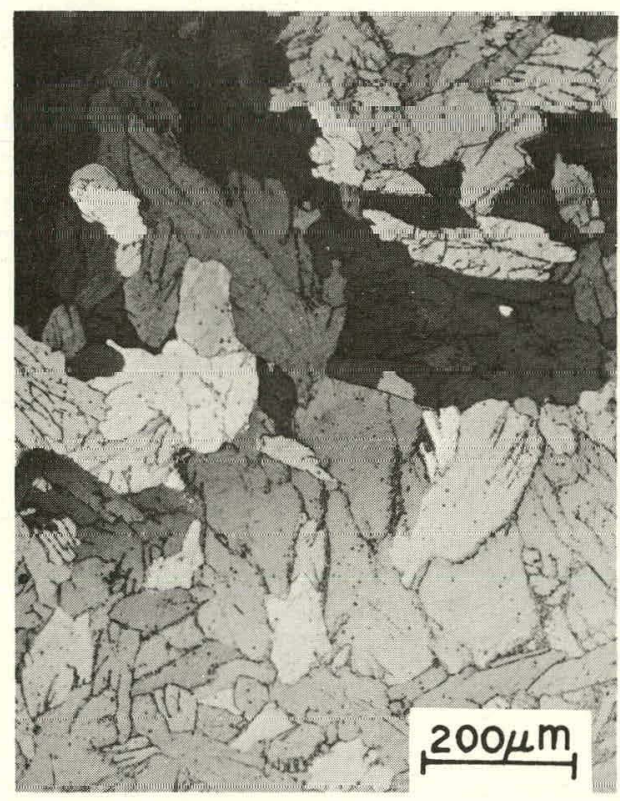

Fig. 51

Microstructure of As-received Zircaloy-4 after Cooling through $\beta \rightarrow \alpha^{\prime}$ Transformation at $0.1^{\circ} \mathrm{C} / \mathrm{s}$ from $1000^{\circ} \mathrm{C}$. ANL Neg. No. 306-77-38.

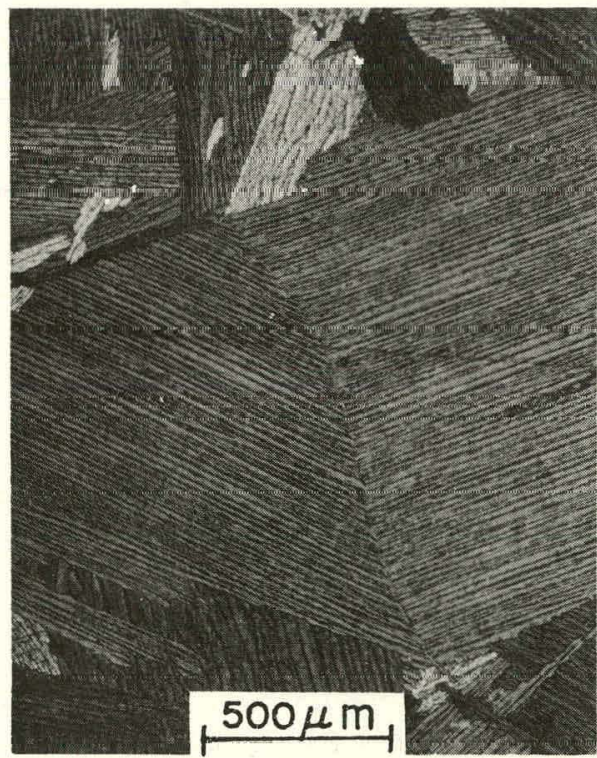

Fig. 52

Parallel-plate Structure of As-received Zircaloy-4 after Cooling through $\beta \rightarrow \alpha^{\prime}$ Transformation at $\sim 2^{\circ} \mathrm{C} / \mathrm{s}$ from $1250^{\circ} \mathrm{C}$. ANL Neg. No. 306-77-35. 


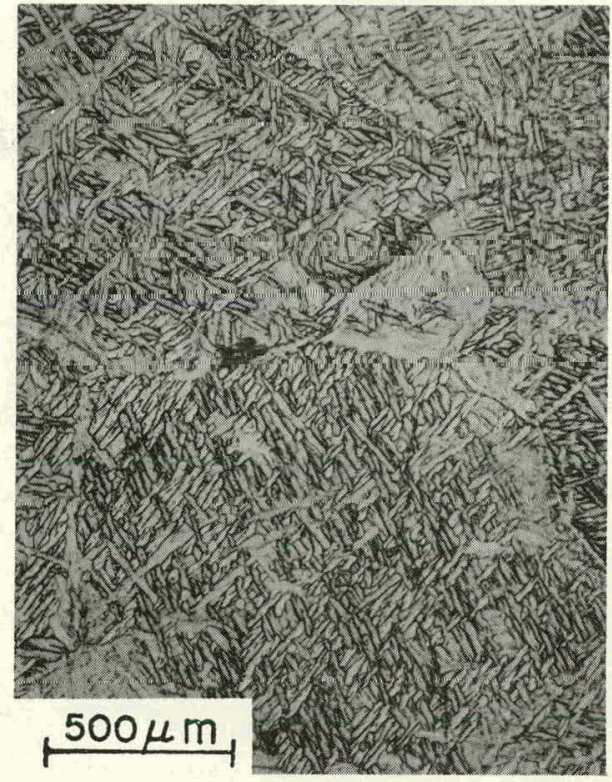

Fig. 53

Basketweave Structure of As-received Zircaloy-4 after Cooling through $\beta \rightarrow \alpha^{\prime}$ Transformation at $\sim 500^{\circ} \mathrm{C} / \mathrm{s}$ from $1000^{\circ} \mathrm{C}$. ANL Neg. No. $306-77-36$.

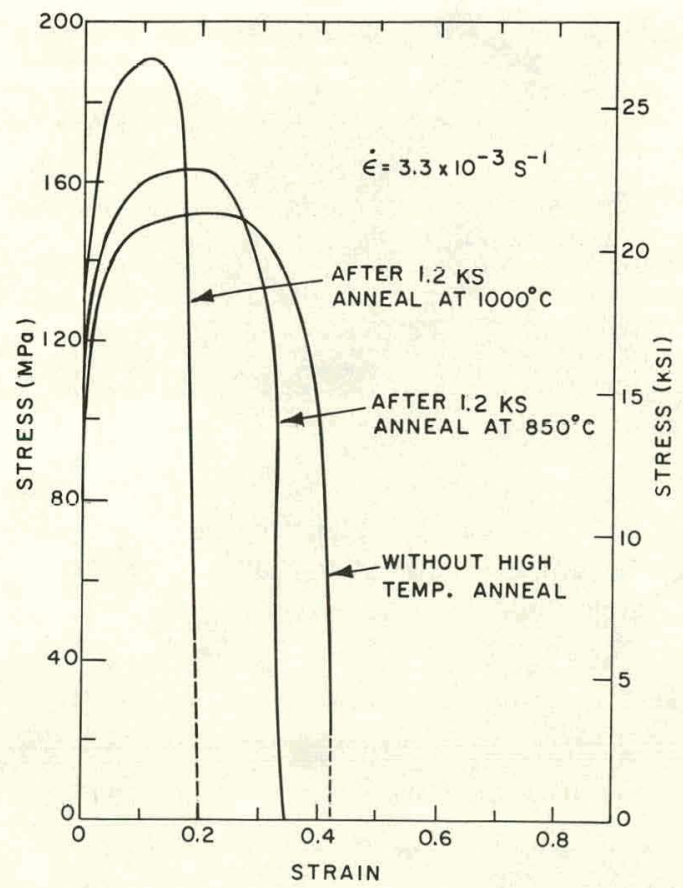

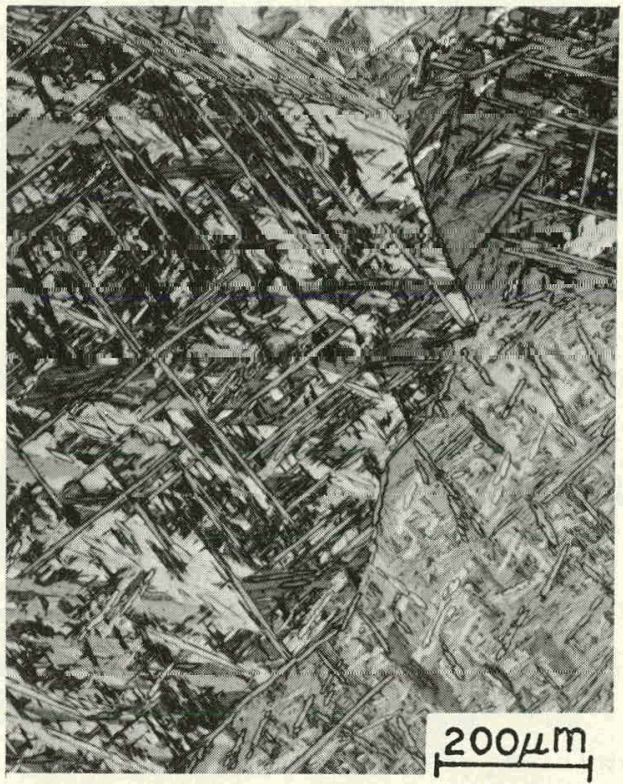

Fig. 54

Martensitic Structure of As-received Zircaloy-4 after Cooling through $\beta \rightarrow \alpha^{\prime}$ Transformation at $\sim 10,000^{\circ} \mathrm{C} / \mathrm{s}$ from $1000^{\circ} \mathrm{C}$. ANL Neg. No. $306-77-34$.

Fig. 55

Effect of $\alpha$-phase Morphology on Engineeringstress/Engineering-strain Curve of 7ircaloy-4 at $400^{\circ} \mathrm{C}$. Neg. No. MSD-61851. 
$\beta$ form, and the remainder will be equiaxed. This heat treatment will result in redistribution of oxygen and possibly other alloying elements during cooling at a rate of $\sim 10^{\circ} \mathrm{C} / \mathrm{s}$ through the two-phase region $\left(980-805^{\circ} \mathrm{C}\right)$. Introduction of a small fraction of $\alpha^{\prime}$ raises the ultimate tensile strength to $\sim 160 \mathrm{MPa}$ and lowers the total strain to $\sim 0.34$. After a 0.6 -ks anneal at $1000^{\circ} \mathrm{C}$, the entire microstructure at $400^{\circ} \mathrm{C}$ will be $\alpha^{\prime}$; the ultimate tensile strength increases to $\sim 190 \mathrm{MPa}$, and the ductility drops to 0.2 total strain. Thus, apart from oxidation effects, the $\beta \rightarrow \alpha$ microstructural transformation also tends to decrease the ductility in Zircaloy that has undergone a high-temperature excursion into the $\beta$-phase field.

Figures 56 and 57 show scanning-electron-microscopy (SEM) fractographs of the as-received and annealed $\left(0.6 \mathrm{ks}\right.$ at $\left.1000^{\circ} \mathrm{C}\right)$ spccimcns, respectively, that were fractured at $400^{\circ} \mathrm{C}$. The as-received spccimen (Fig. 56) showed the typical equiaxed dimples that failed as a result of normal strcss; the fracture surface was perpendicular to the tensile axis. The fracture region of the $\alpha^{\prime}$ material (Fig. 57) showed elongated dimples that failed as a result of shear stress; the fracture surface was $\sim 45^{\circ}$ to the tensile axis.

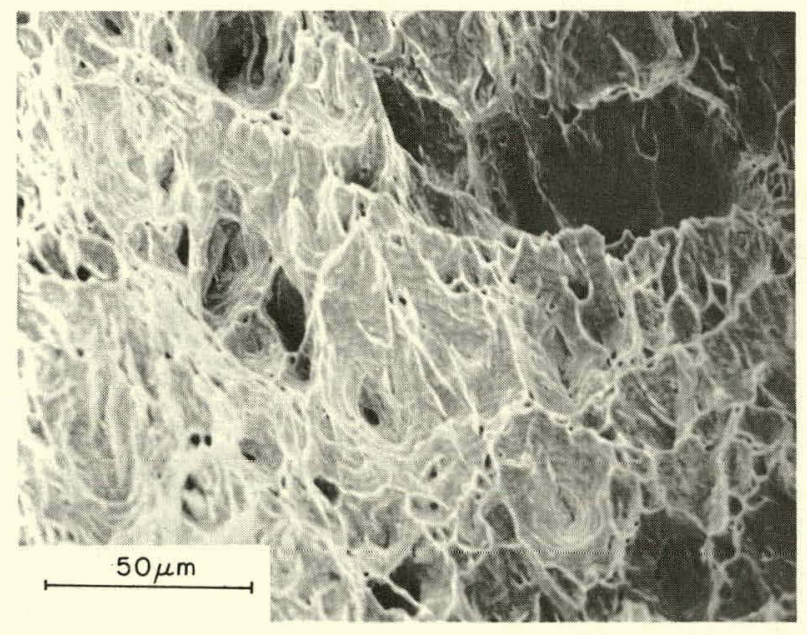

Fig. 50

SEM Fractograph of As-received Zircaloy-4 Specimen Fractured at $400^{\circ} \mathrm{C} ; \dot{\epsilon}=3.3 \mathrm{x}$ $10^{-3} \mathrm{~s}^{-1}$. ANL Neg. No, 306-75-119 Rev. 1.

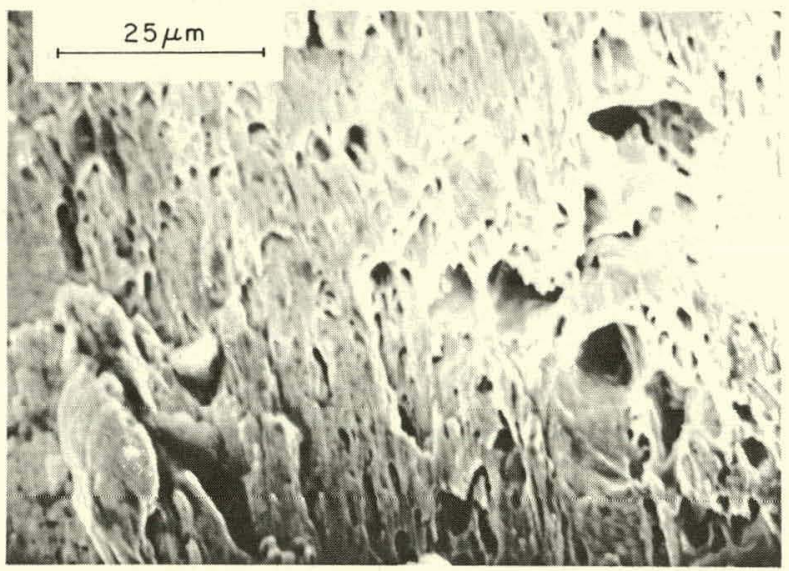

Fig. 57

SEM Fractograph of Transformed $\beta$-phase Zircaloy-4 Specimen Fractured at $400^{\circ} \mathrm{C} ; \dot{\epsilon}=3.3 \times 10^{-3} \mathrm{~s}^{-1}$. ANL Neg. No. 306-75-125 Rev. 1.

Figure 58 shows the effect of $\alpha$-phase morphology on the temperature dependence of the total strain. The lower curve in Fig. 58 shows the total strain of samples that were heated to $1000^{\circ} \mathrm{C}$ and then cooled at $\sim 3^{\circ} \mathrm{C} / \mathrm{s}$ through the two-phase region to the deformation temperatures, which resulted in a basketweave-type structure at the start of deformation. A comparisurn of these data shows that morphology has a pronounced effect on the total elongation. This is particularly evident between 800 and $850^{\circ} \mathrm{C}$, where the large superplastic elongations were not observed for the transformed $\beta\left(\alpha^{\prime}\right)$ materia] 


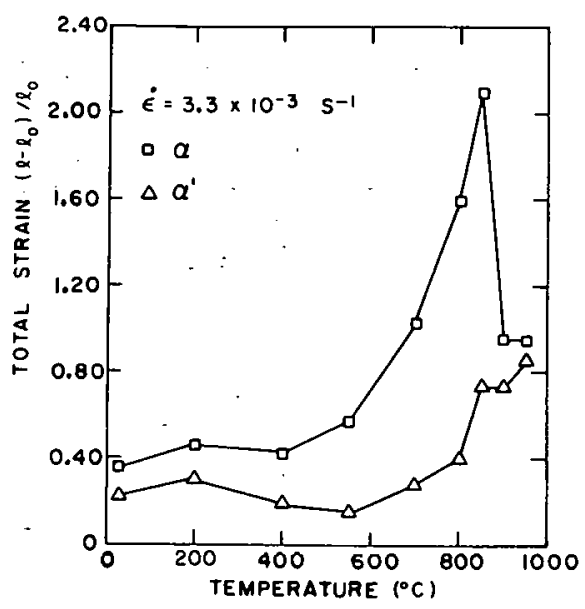

Fig. 58

Influence of $\alpha$-phase Morphology on Total Strain of Zircaloy-4 at Temperatures between Ambient and $950^{\circ} \mathrm{C}$. ANL Neg. No. 306-75-195 Rev. 2.

Figure 59 shows the temperature dependence of the ultimate tensile strength of $\mathrm{Zircaloy}-4$ with equiaxed $\alpha$ and $\operatorname{transformed} \beta$ basketweave microstructures. The ultimate tensile strength for both types of specimens decreases continously as the temperature increases. Both curves show a hump near $400^{\circ} \mathrm{C}$, which is a manifestation of dynamic strain aging. Figure 60 shows the temperature dependence of the strain-rate sensitivity of specimens with the two types of microstructure. Both curves show a minimum at $400^{\circ} \mathrm{C}$, another indication of dynamic strain aging. The strain-rate sensitivity of

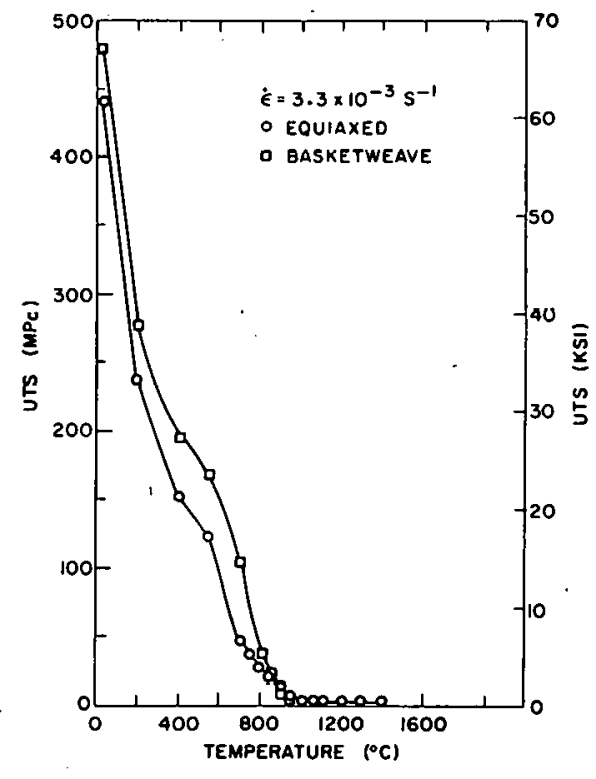

Fig. 59

Temperature Dependence of Ultimate Tensile Strength of Zircaloy-4 with Equiaxed and Basketweave Microstructures. ANL Neg. No. 306-77-92 .

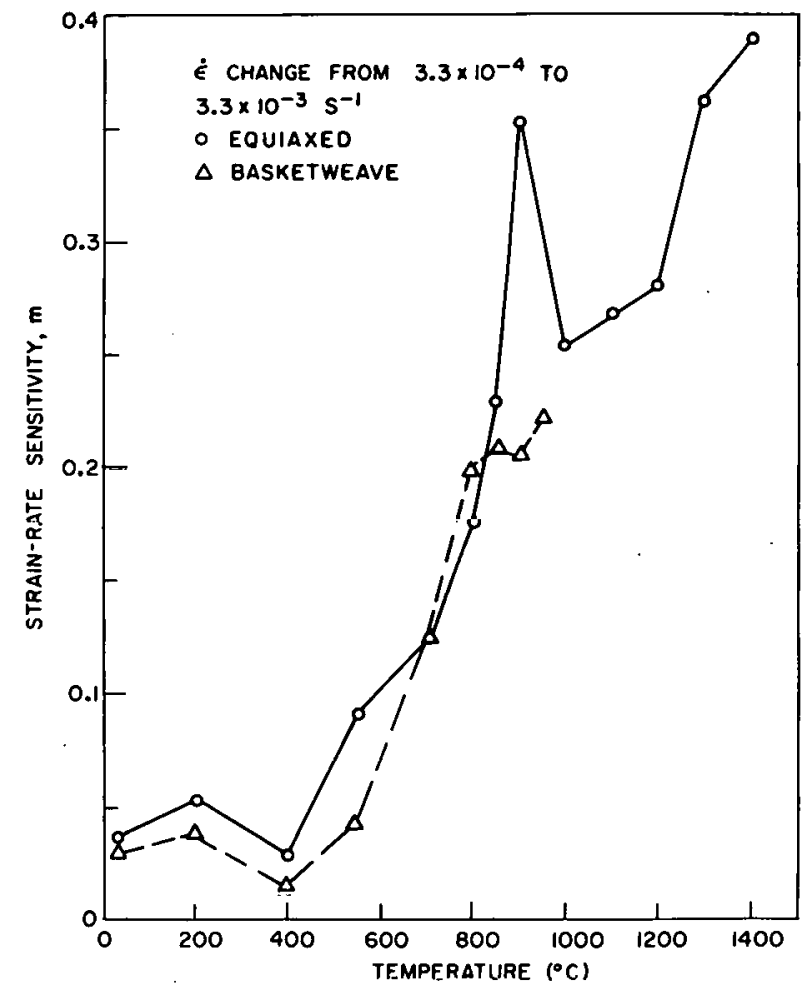

Fig. 60

Strain-rate Sensitivity as a Function of Temperature for Zircaloy-4 Specimens with Equiaxed Grains and Basketweave Structure; $\epsilon \simeq 0.02$. ANL Neg. No. 306-77-91. 
specimens with basketweave microstructure does not show a peak at $900^{\circ} \mathrm{C}$ (Fig. 60), which is consistent with the observed (Fig. 58) decrease in the extent of superplasticity in the transformed $\beta$ phase. Figure 61 shows the strain-rate dependence of the strain-rate sensitivity of Zircaloy-4 at $850^{\circ} \mathrm{C}$. Although the strain-rate sensitivity of the equiaxed material increases rapidly as the strain rate decreases, the basketweave structure does not show a significant strain-rate dependence. This is another indication that superplasticity is as sociated with an equiaxed structure at lower strain rates.

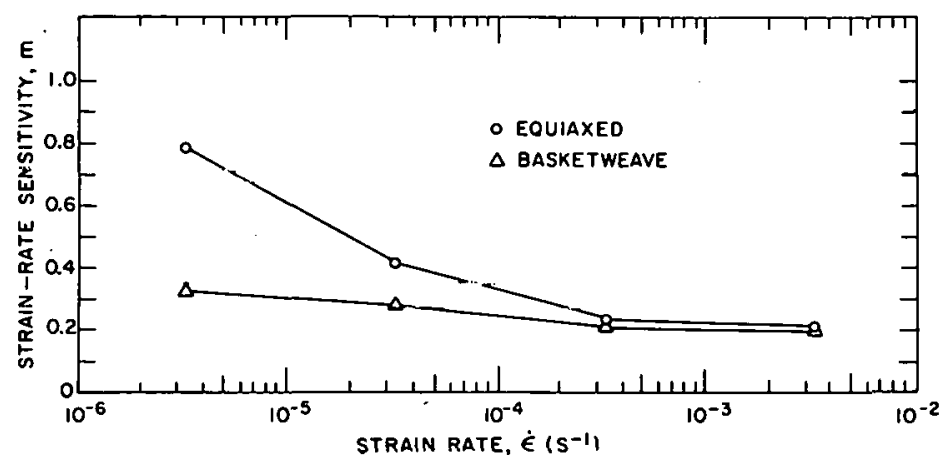

Fig 61

Strain-rate Deperudence of Strainrate Sensitivity of Zircaloy-4 with Equiaxed Grains and Basketweave Structure at $850^{\circ} \mathrm{C} ; \epsilon \simeq 0.02$. ANL Neg. No. 306-77-90.

Figure 62 shows the variation of the ultimate lensile strength with temperature for the basketweave structure. Above $\sim 500^{\circ} \mathrm{C}$, the strength is greater for the higher strain rate; i.e., the normal strain-rate dependence is exhibited. However, at 200 and $500^{\circ} \mathrm{C}$, dynamic strain aging results in a higher strength for the slower strain rate.

Fig. 62

Temperature Dependence of UItimate Tensile Strength of Transformed $\beta$-phase Basketweave Zilcaluy 4 at Two Gtrain Rates. ANL Nog. No. 306-76-11 Rev. 2 .

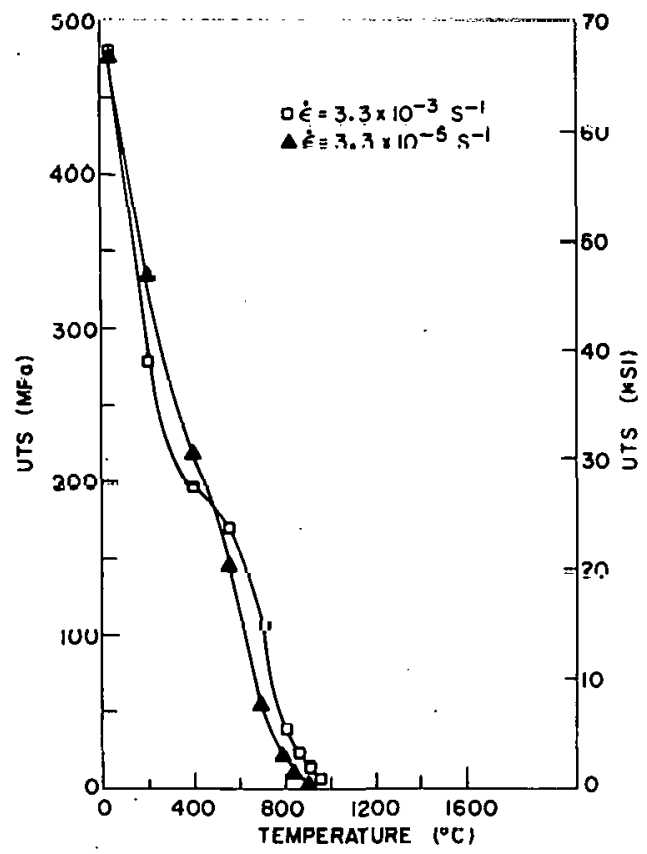

Variations of the total strain with temperature for basketweave structure are shown in Fig. 63 at two strain rates. The large elongation peak observed in equiaxed material at $850^{\circ} \mathrm{C}$ is not present in the data from the $\alpha^{\prime}$ 


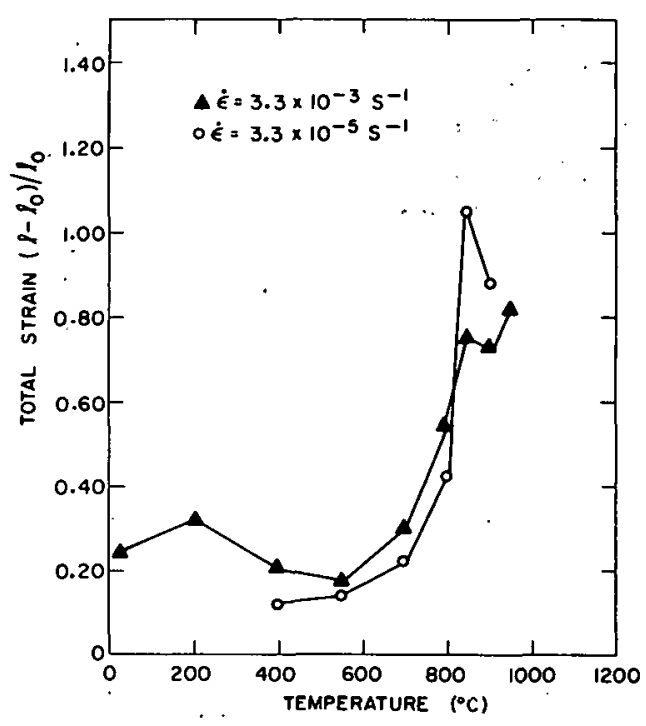

Fig. 63

Effect of Strain Rate on Total Strain of Zircaloy-4 with Basketweave Structure at Temperatures between Ambient and $1000^{\circ} \mathrm{C}$. ANL Neg. No. 306-76-24 Rev. 1 . specimens at $\dot{\varepsilon}=3.3 \times 10^{-3} \mathrm{~s}^{-1}$. A microstructural examination of the $\alpha^{\prime}$ specimen deformed at $850^{\circ} \mathrm{C}, \dot{\varepsilon}=3.3 \times 10^{-3} \mathrm{~s}^{-1}$, did not show a significant number of grains with equiaxed shape. When the strain rate was decreased to $3.3 \times 10^{-5} \mathrm{~s}^{-1}$, however, the elongation increased to $\sim 105 \%$. The microstructure in the deformed region, in this case, revealed a large fraction of equiaxed grains. These results imply that, at sufficiently low strain rates $\left(<10^{-5} \mathrm{~s}^{-1}\right)$, superplastic deformation reappears in transformed $\beta$-phase material as the equiaxed grain shape is achieved by grain-boundary migration.

Figure 64 shows the temperature dependence of the ultimate tensile strength of Zircaloy transformed from the $\beta$ phase at cooling rates of 3 and $1^{\circ} \mathrm{C} / \mathrm{s}$ (coarse basketweave and coarse parallel-plate structures, respectively). The strength behavior is almost identical for the two types of microstructure.

Figure 65 shows the corresponding total strain variation with temperature. At all temperatures, the basketweave structure is more ductile than the parallel-plate structure.

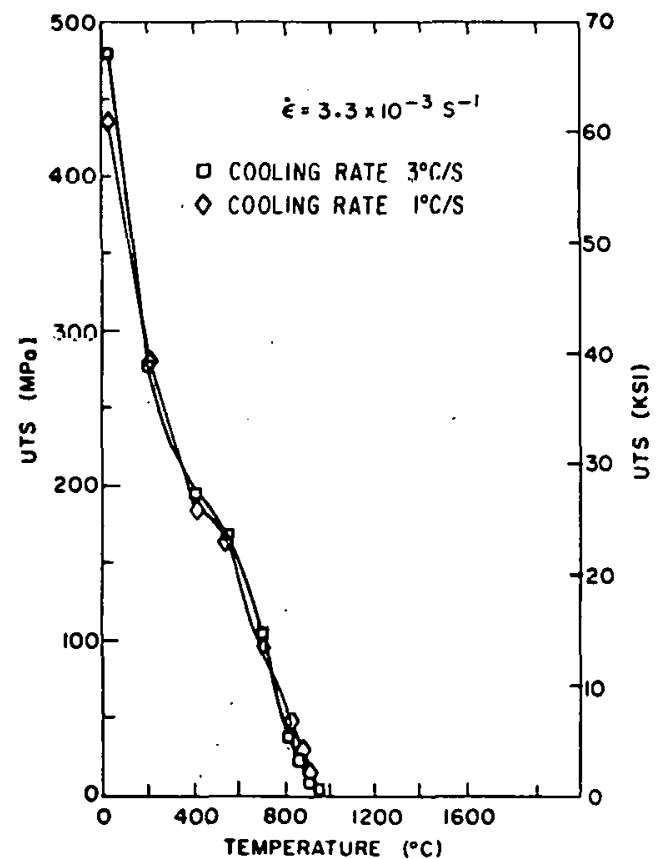

Fig. 64

Ultimate Tensile Strength as a Function of Temperature for Transformed B-phase Zircaloy-4 with Basketweave and Parällel-piate structures. ANL Neg. No. 306-77-113.

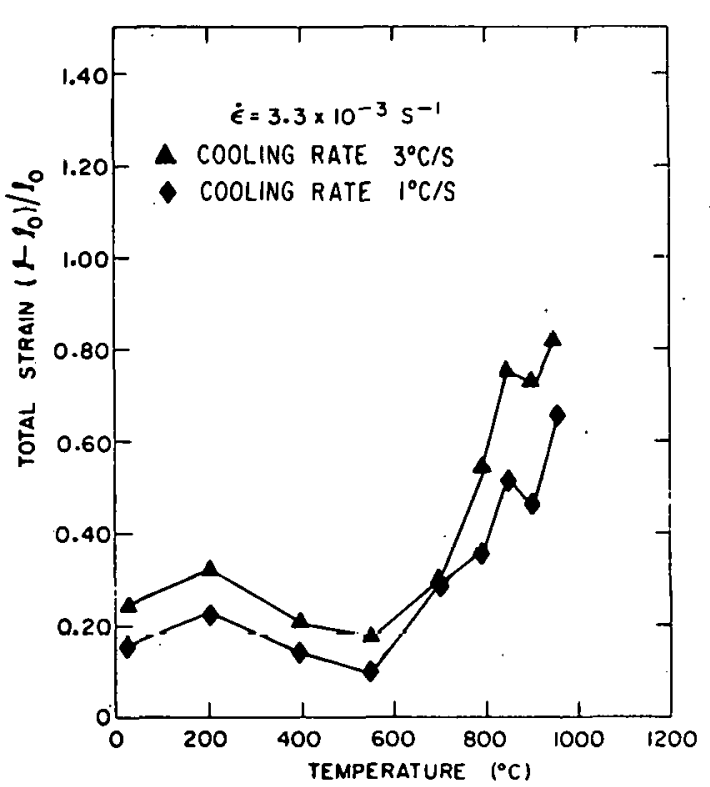

Fig. 65

Temperature Dependence of Total Strain of Transformed $B$-phase Zircaloy-4 with Basketweave and Parallel-plate Structures. ANL Neg. No. 306-77-114. 
Figures 66-69 show the cooling-rate dependence of yield stress, ultimate tensile strength, uniform strain, and total strain, respectively, at various temperatures. These data refer to tensile specimens with a widthto-thickness ratio $(w / t)$ of 5 . The transformed $\beta$ structure was obtained by heating the as-received equiaxed homogeneous $\alpha$ structure into the $\beta$ field $\left(1000^{\circ} \mathrm{C}\right)$ and then cooling the specimen through the two-phase region (805$980^{\circ} \mathrm{C}$ ) at the designated cooling rate. Cooling rates of less than $3^{\circ} \mathrm{C} / \mathrm{s}$ could

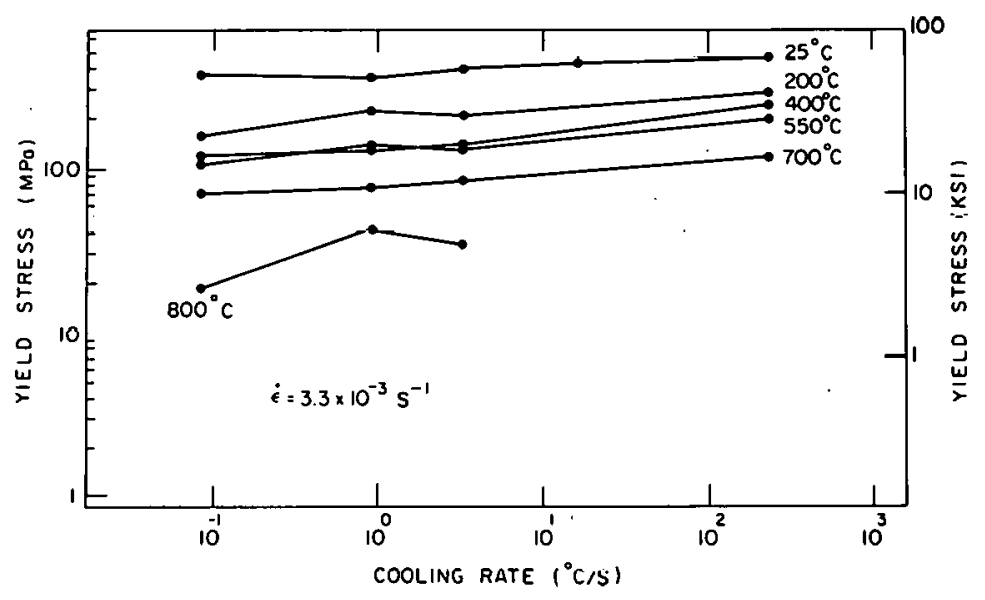

Fig. 66

Effect of Cooling Rate on Yield Stress of Transformed B-phase Zircaloy-4 at Several Temperatures. Neg. No. MSD-63835.

Fig. 67

Influence of Cooling Rate on Ultimate Tensile Strength of Transformed B-phase Zircaloy-4 at Several Temperatures. Neg. No. MSD-63847.
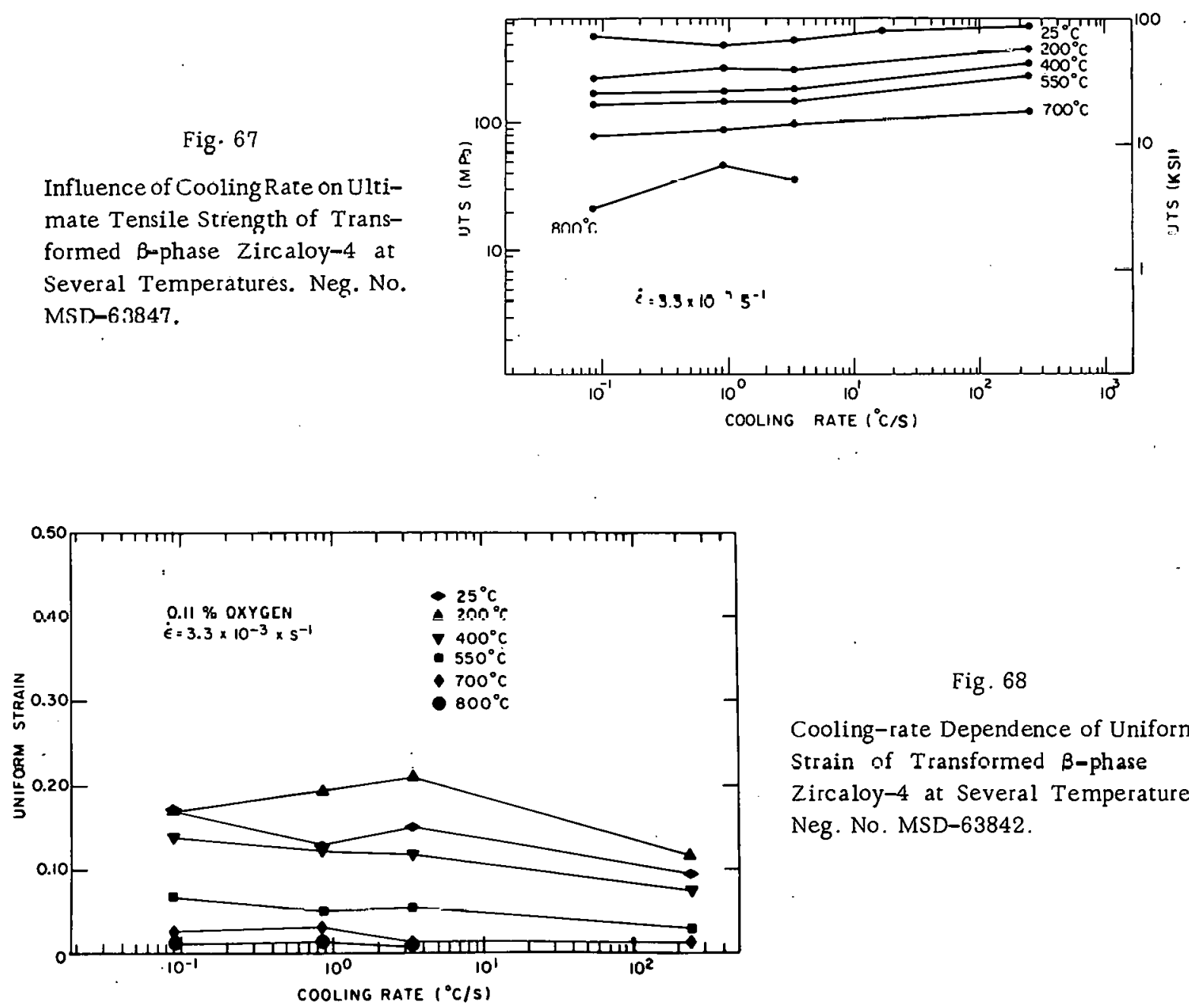

Fig. 68

Cooling-rate Dependence of Uniform Strain of Transformed B-phase Zircaloy 4 at Several Temperatures. Neg. No. MSD-63842. 


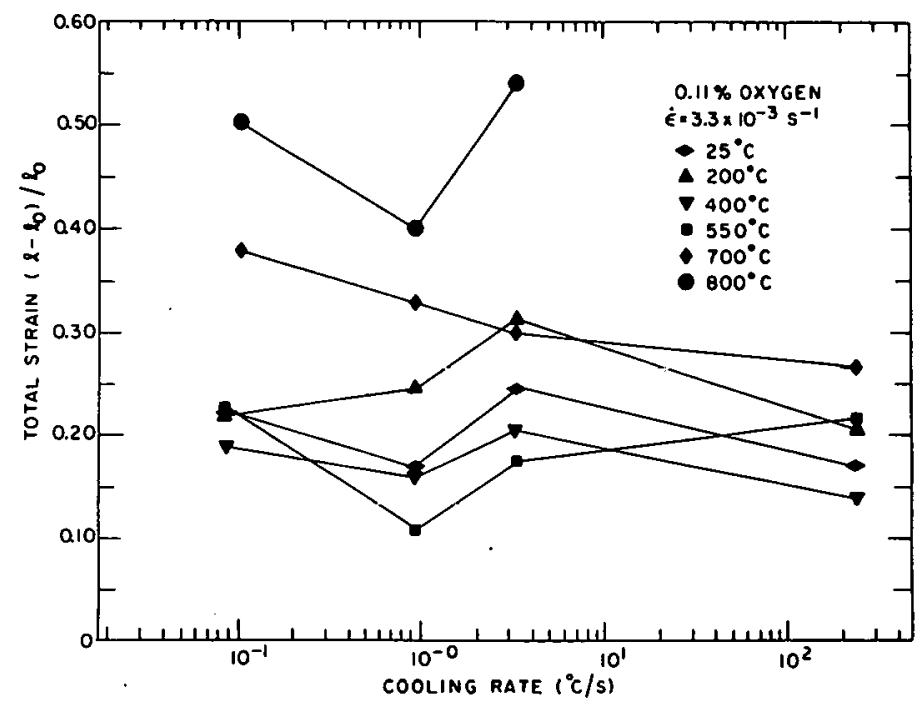

Fig. 69

Total Strain as a Function of Cooling Rate for Transformed ß-phase Zircaloy-4 at Several Temperatures. Neg. No. MSD-63844.

compared to the lenticular structure produced at the slower cooling rate of $9 \times 10^{-2 \circ} \mathrm{C} / \mathrm{s}$. Consistent with the well-known grain-size effect on the flow stress (Petch effect), the finer structure is stronger.

Solute redistribution during the phase transformation is another factor that contributes to the cooling rate dependence of the flow stress. It was shown ${ }^{2}$ that considerable oxygen redistribution takes place at the slower cooling rates $\left(<1^{\circ} \mathrm{C} / \mathrm{s}\right)$ such that the central portion of the $\alpha^{\prime}$ plates become en riched in oxygen and the boundary region between two adjacent $\alpha^{\prime}$ plates becomes depleted in oxygen. At faster cooling rates $\left(>3^{\circ} \mathrm{C} / \mathrm{s}\right)$, the extent of oxygen (and other alloying elements) redistribution is less. The inhomogeneous structures produced at low cooling rates are weaker than the fairly homogeneous structures produced at the faster cooling rates.

The data in Figs. 68 and 69 show that the basketweave structure produced at the cooling rate of $\sim 3^{\circ} \mathrm{C} / \mathrm{s}$ exhibits uniform strain and total strain that are higher than those of the microstructures formed at the other cooling rates. This effect is believed to be due to the interlocking nature of the basketweave structure. Since the matrixorientation within two adjacent nonparallel subgrains ("fibers") is significantly different, the interlocking nature of basketweave structure gives rise to a work-hardening effect. The uniform strain of the basketweave structure at $200^{\circ} \mathrm{C}$ (Fig. 68) is higher than that at 25 and $400^{\circ} \mathrm{C}$. This is probably due to the higher work-hardening rate at $200^{\circ} \mathrm{C}$ associated with dynamic strain aging. From a comparison of the mechanical properties of different microstructures in Figs, 66-69, we can conclude that the basketweave structure exhibits both good strength and good ductility. 
Figures 70 and 71 , respectively, show the temperature dependence of the uniform strain and total strain for four cooling rates (microstructures) and two specimen geometries. The peak uniform strain at $200^{\circ} \mathrm{C}$ (Fig. 70 ) is due to the high work-hardening rate associated with dynamic strain aging. At temperatures above $400^{\circ} \mathrm{C}$, the uniform strain decreases rapidly due to the decrease in work-hardening rate because of the larger extent of dynamic recovery at higher temperatures. The plot of total strain versus temperature (Fig. 71) shows a minimum in the temperature interval

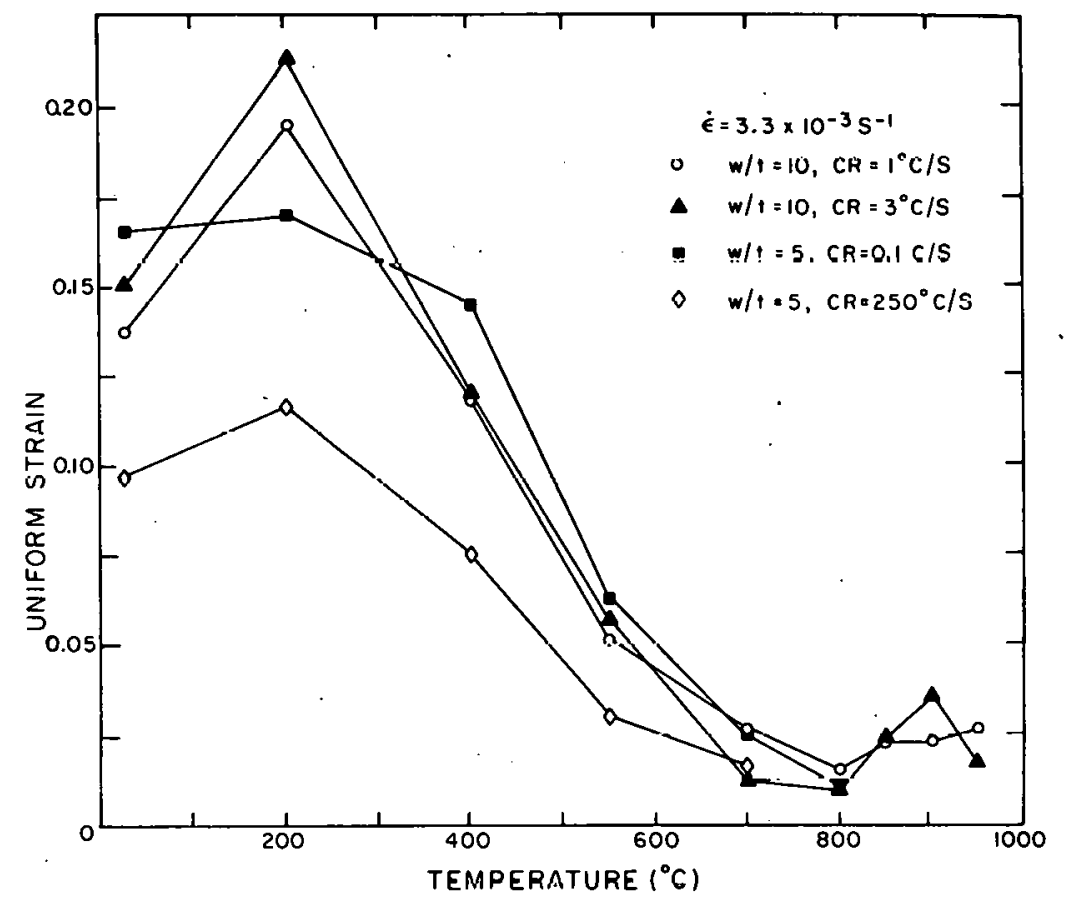

Fig. 70. Uniform Strain vs Temperature for Transformed B-phase Zircaloy-4 at Various Cooling Rates. ANL Neg. No. 306-77-111.

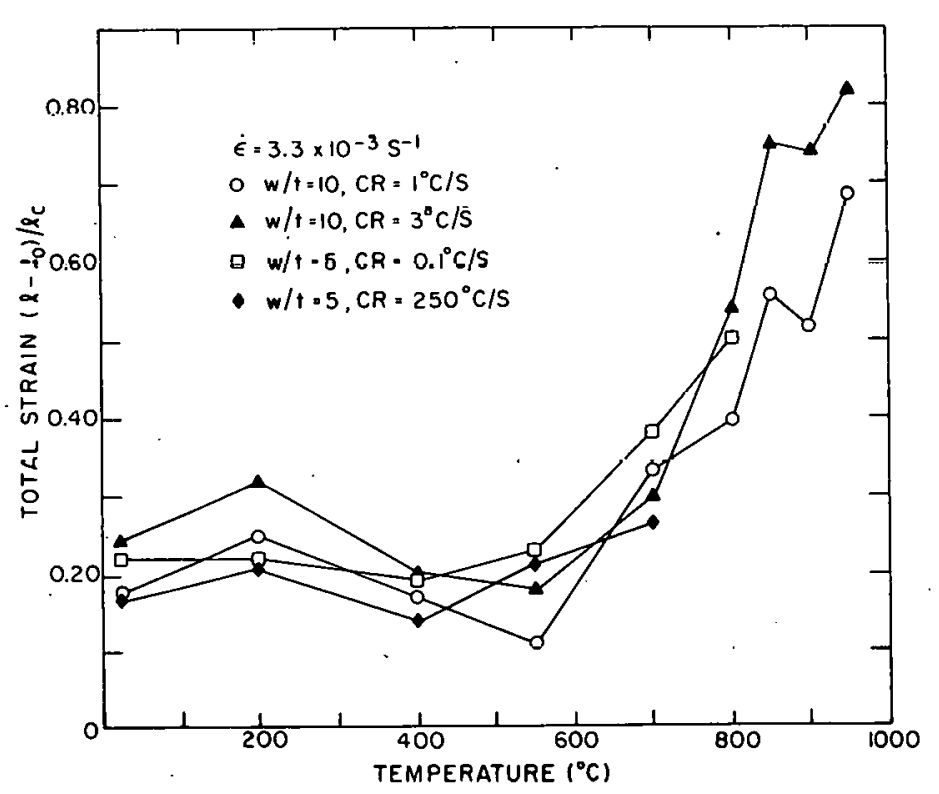

Fig. 71

Total Strain as a Function of Temperature for Transformed $\beta$-phase Zircaloy-4 at Various Cooling Rates. ANL Neg. No. 306-77-110. 
$400-550^{\circ} \mathrm{C}$, which can be attributed to dynamic strain aging. Above $600^{\circ} \mathrm{C}$, the total strain increases due to dynamic recovery.

The work-hardening rate analysis of Zircaloy-4 with three types of transformed $\beta$ microstructures is presented in Tables XIII-XVII and Figs. 72 and 73 . The work-hardening exponent shows a maximum value between 200 and $400^{\circ} \mathrm{C}$ due to dynamic strain aging and negative values with a minimum between 700 and $900^{\circ} \mathrm{C}$ due to intergranular deformation.

\section{Dynamic Strain Aging near $750^{\circ} \mathrm{C}$}

Figure 74 represents partial Instron load-elongation curves obtained from Zircaloy-4 specimens deformed at $750^{\circ} \mathrm{C}$ after various heat treatments. Curve A shows the partial load-elongation curve for as-received material (cold-rolled and vacuum-annealed at $732^{\circ} \mathrm{C}$ for $7.2 \mathrm{ks}$ ) deformed at $750^{\circ} \mathrm{C}$ after a $0.6-\mathrm{ks}$ hold time at $750^{\circ} \mathrm{C}$. Note the pronounced yield point. Curve B represents another specimen, which was deformed to a strain of $\sim 0.02$ under identical conditions and unloaded. This specimen was then held at $750^{\circ} \mathrm{C}$ for $14.4 \mathrm{ks}$ and strained again at the same rate at $750^{\circ} \mathrm{C}$. No yield point is evident in the load-elongation response in curve $\mathrm{C}$.

TABLE XIII. Least-squares Work-hardening Constants for Deformation Stages of Transformed $\beta$-phase Zircaloy-4; Cooling Rate $\simeq 0.1^{\circ} \mathrm{C} / \mathrm{s} ; \dot{\varepsilon}=3.3 \times 10^{-3} \mathrm{~s}^{-1}$

\begin{tabular}{ccccrc}
\hline $\begin{array}{c}\text { Temp, } \\
{ }^{\circ} \mathrm{C}\end{array}$ & $\begin{array}{c}\text { Stage } \\
\text { Number }\end{array}$ & $\begin{array}{c}\text { Strain } \\
\text { Interval }\end{array}$ & $\mathrm{n}$ & $\mathrm{k}, \mathrm{Pa}$ & $\begin{array}{c}\text { Average } \\
\sigma_{0}, \mathrm{~Pa}\end{array}$ \\
\hline 25 & 1 & $0.0004-0.0032$ & 0.71 & $4.6 \times 10^{8}$ & $3.8 \times 10^{7}$ \\
& 2 & $0.0036-0.015$ & -0.86 & $-4.9 \times 10^{4}$ & $5.2 \times 10^{7}$ \\
200 & 1 & $0.0004-0.0028$ & 0.71 & $2.8 \times 10^{9}$ & $1.1 \times 10^{8}$ \\
& 2 & $0.0032-0.014$ & -0.25 & $-2.5 \times 10^{7}$ & $2.6 \times 10^{8}$ \\
& 3 & $0.015-0.13$ & 0.38 & $2.6 \times 10^{8}$ & $1.4 \times 10^{8}$ \\
400 & 1 & $0.0004-0.0028$ & 0.68 & $1.2 \times 10^{9}$ & $9.1 \times 10^{7}$ \\
& 2 & $0.0032-0.11$ & 0.31 & $2.2 \times 10^{8}$ & $8.0 \times 10^{7}$ \\
550 & 1 & $0.0004-0.0024$ & 0.74 & $1.7 \times 10^{9}$ & $8.5 \times 10^{7}$ \\
& 2 & $0.0028-0.05$ & 0.04 & $4.6 \times 10^{8}$ & $-2.6 \times 10^{8}$ \\
700 & 1 & $0.0004-0.0036$ & 0.83 & $1.1 \times 10^{9}$ & $.6 .1 \times 10^{7}$ \\
& 2 & $0.004-0.025$ & -0.51 & $-6.0 \times 10^{5}$ & $8.6 \times 10^{7}$ \\
800 & 2 & $0.0004-0.01$ & -0.3 & $-1.5 \times 10^{6}$ & $5.1 \times 10^{7}$ \\
\hline
\end{tabular}


TABLE XIV. Least-squares Work-hardening Constants for Deformation Stages of Longitudinal Zircaloy-4 Specimens with Parallel-plate Structure; Cooling Rate $\approx 1^{\circ} \mathrm{C} / \mathrm{s} ; \dot{\epsilon}=3.3 \times 10^{-3} \mathrm{~s}^{-1}$

\begin{tabular}{cccccc}
\hline $\begin{array}{c}\text { Temp } \\
{ }^{\circ} \mathrm{C}\end{array}$ & $\begin{array}{c}\text { Stage } \\
\text { Number }\end{array}$ & $\begin{array}{c}\text { Strain } \\
\text { Interval }\end{array}$ & $\mathrm{n}$ & $\mathbf{k}, \mathrm{Pa}$ & $\begin{array}{c}\text { Average } \\
\sigma_{0}, \mathrm{~Pa}\end{array}$ \\
\hline 23 & 2 & $0.0004-0.13$ & 0.16 & $3.9 \times 10^{8}$ & $2.0 \times 10^{8}$ \\
200 & 1 & $0.0004-0.02$ & -0.04 & $-3.8 \times 10^{8}$ & $7.0 \times 10^{8}$ \\
& 2 & $0.025-0.15$ & 0.70 & $3.1 \times 10^{8}$ & $2.3 \times 10^{8}$ \\
400 & 1 & $0.0004-0.0032$ & -0 & $6.3 \times 10^{11}$ & $-6.3 \times 10^{11}$ \\
& 2 & $0.0036-0.09$ & 0.36 & $2.2 \times 10^{8}$ & $1.0 \times 10^{8}$ \\
550. & 1 & $0.0004-0.0032$ & 0.66 & $1.3 \times 10^{9}$ & $9.4 \times 10^{7}$ \\
& 2 & $0.0036-0.05$ & -0.13 & $-6.1 \times 10^{7}$ & $2.5 \times 10^{8}$ \\
700 & 1 & $0.0004-0.008$ & 0.07 & $1.6 \times 10^{8}$ & $-3.2 \times 10^{7}$ \\
& 2 & $0.009-0.015$ & -2.1 & $-2.0 \times 10^{2}$ & $9.0 \times 10^{7}$ \\
800 & 1 & $0.0004-0.0016$ & 0.69 & $6.8 \times 10^{8}$ & $3.3 \times 10^{7}$ \\
& 2 & $0.0020-0.012$ & -0.88 & $-2.5 \times 10^{4}$ & $4.8 \times 10^{7}$ \\
850 & 1 & $0.0004-0.0016$ & 0.61 & $3.0 \times 10^{8}$ & $2.0 \times 10^{7}$ \\
& 2 & $0.0020-0.015$ & -0.58 & $-9.4 \times 10^{4}$ & $3.1 \times 10^{7}$ \\
900 & 1 & $0.0004-0.0016$ & 0.15 & $1.8 \times 10^{7}$ & $7.3 \times 10^{6}$ \\
& 2 & $0.0020-0.015$ & -0.63 & $-3.1 \times 10^{4}$ & $1.6 \times 10^{7}$ \\
950 & 1 & $0.0004-0.0028$ & 0.58 & $5.9 \times 10^{7}$ & $4.9 \times 10^{6}$ \\
& 2 & $0.0032-0.014$ & -1.5 & $-1.5 \times 10^{2}$ & $7.8 \times 10^{6}$ \\
\hline
\end{tabular}

TABLE $\hat{X V}$. Least-squares Work-hardening Constants for Deformation Stages of Longitudinal Zircaloy-4 Specimens with Basketweave Structure; Cooling Rate $\simeq 3^{\circ} \mathrm{C} / \mathrm{s} ; \dot{\varepsilon}=3.3 \times 10^{-3} \mathrm{~s}^{-1}$

\begin{tabular}{|c|c|c|c|c|c|}
\hline$\underset{{ }^{\circ} \mathrm{C}}{\text { Tomp }}$ & $\begin{array}{c}\text { Stage } \\
\text { Number }\end{array}$ & $\begin{array}{l}\text { Strain } \\
\text { Interval }\end{array}$ & $\mathrm{n}$ & $\mathrm{k}, \mathrm{Pa}$ & $\begin{array}{c}\text { Average } \\
\sigma_{0}, \mathrm{~Pa}\end{array}$ \\
\hline \multirow[t]{2}{*}{23} & 2 & $0.0001 \quad 0.008$ & 0.05 & $=6.8 \times 10^{8}$ & $-1.4 \times 10^{7}$ \\
\hline & 3 & $0.008-0.09$ & 0.37 & $3.3 \times 10^{8}$ & $3.8 \times 10^{8}$ \\
\hline \multirow[t]{2}{*}{200} & 2 & $0.0004-0.045$ & 0.07 & $3.8 \times 10^{8}$ & $-3.9 \times 10^{7}$ \\
\hline & 3 & $0.05-0.17$ & 0.71 & $3.1 \times 10^{8}$ & $2.3 \times 10^{8}$ \\
\hline \multirow[t]{2}{*}{400} & 1 & $0.0004-0.0012$ & 0.84 & $4.0 \times 10^{9}$ & $1.1 \times 10^{8}$ \\
\hline & 2 & $0.0016-0.11$ & 0.17 & $2.3 \times 10^{8}$ & $5.5 \times 10^{\prime}$ \\
\hline $55 n$ & 2 & $0.0004-0.04$ & 0.03 & $5.6 \times 10^{8}$ & $-3.5 \times 10^{8}$ \\
\hline \multirow[t]{2}{*}{$70 n$} & 2 & $0.0001: 0.001$ & 0.17 & $1.8 \times 10^{8}$ & $1.9 \times 10^{7}$ \\
\hline & 3 & $0.005-0.01$ & -2.60 & $-7.6 \times 10^{0}$ & $1.0 \times 10^{8}$ \\
\hline \multirow[t]{2}{*}{800} & 1 & $0.0004-0.0012$ & 0.64 & $4.5 \times 10^{8}$ & $2.6 \times 10^{7}$ \\
\hline & 2 & $0.0016-0.01$ & -0.76 & $-3.5 \times 10^{4}$ & $3.8 \times 10^{7}$ \\
\hline 850 & 2 & $0.0004-0.015$ & -0.51 & $-1.7 \times 10^{5}$ & $3.1 \times 10^{7}$ \\
\hline \multirow[t]{2}{*}{900} & 1 & $0.0004-0.002$ & 0.16 & $3.2 \times 10^{7}$ & $-7.7 \times 10^{5}$ \\
\hline & 2 & $0.0024-0.025$ & -0.58 & $-7.6 \times 10^{4}$ & $1.4 \times 10^{7}$ \\
\hline \multirow[t]{2}{*}{950} & 1 & $0.0004-0.002$ & -0.003 & $-2.0 \times 10^{8}$ & $2.1 \times 10^{8}$ \\
\hline & 2 & $0.0024-0.015$ & -0.71 & $-1.0 \times 10^{4}$ & $6.5 \times 10^{6}$ \\
\hline
\end{tabular}


TABLE XVI. Least-squares Work-hardening Constants for Deformation Stages of Longitudinal Zircaloy-4 Specimens with Martensitic Structure; Cooling Rate $\approx 10,000^{\circ} \mathrm{C} / \mathrm{s} ; \dot{\varepsilon}=3.3 \times 10^{-3} \mathrm{~s}^{-1}$

\begin{tabular}{cccccr}
\hline $\begin{array}{c}\text { Temp, } \\
{ }^{\circ} \mathrm{C}\end{array}$ & $\begin{array}{c}\text { Stage } \\
\text { Number }\end{array}$ & $\begin{array}{c}\text { Strain } \\
\text { Interval }\end{array}$ & $\mathbf{n}$ & $\mathrm{k}, \mathrm{Pa}$ & $\begin{array}{c}\text { Average } \\
\sigma_{0}, \mathrm{~Pa}\end{array}$ \\
\hline 25 & 1 & $0.0004-0.0036$ & 0.75 & $4.7 \times 10^{9}$ & $4.1 \times 10^{8}$ \\
& 2 & $0.004-0.07$ & 0.07 & $1.1 \times 10^{9}$ & $-2.5 \times 10^{8}$ \\
200 & 2 & $0.0004-0.09$ & 0.22 & $4.5 \times 10^{8}$ & $1.8 \times 10^{8}$ \\
400 & 1 & $0.0004-0.0032$ & 0.68 & $2.7 \times 10^{9}$ & $1.9 \times 10^{8}$ \\
& 2 & $0.0036-0.05$ & -0.09 & $-2.0 \times 10^{8}$ & $5.9 \times 10^{8}$ \\
550 & 1 & $0.0004-0.004$ & 0.65 & $1.9 \times 10^{9}$ & $1.6 \times 10^{8}$ \\
& 2 & $0.005-0.025$ & -0.80 & $-7.1 \times 10^{5}$ & $2.6 \times 10^{8}$ \\
700 & 1 & $0.0004-0.006$ & 0.16 & $1.5 \times 10^{8}$ & $5.3 \times 10^{7}$ \\
& 2 & $0.007-0.015$ & -1.90 & $-4.7 \times 10^{2}$ & $1.3 \times 10^{8}$ \\
\hline
\end{tabular}

TABLE XVII. Least-squares Work-hardening Constants for Deformation Stages of Longitudinal Zircaloy-4 Specimens with Basketweave Structure; Cooling Rate $\approx 3^{\circ} \mathrm{C} / \mathrm{s} ; \dot{\varepsilon}=3.3 \times 10^{-5} \mathrm{~s}^{-1}$

\begin{tabular}{rrlrrr}
\hline $\begin{array}{c}\text { Temp } \\
{ }^{\circ} \mathrm{C}\end{array}$ & $\begin{array}{c}\text { Stage } \\
\text { Number }\end{array}$ & \multicolumn{1}{c}{$\begin{array}{c}\text { Strain } \\
\text { Interval }\end{array}$} & $\mathrm{n}$ & $\mathrm{k}, \mathrm{Pa}$ & $\begin{array}{c}\text { Average } \\
\sigma_{0}, \mathrm{~Pa}\end{array}$ \\
\hline 23 & 2 & $0.0004-0.13$ & 0.23 & $5.3 \times 10^{8}$ & $1.9 \times 10^{8}$ \\
200 & 2 & $0.0004-0.15$ & 0.26 & $4.5 \times 10^{8}$ & $1.0 \times 10^{8}$ \\
400 & 2 & $0.0004-0.07$ & 0.12 & $2.8 \times 10^{8}$ & $1.8 \times 10^{7}$ \\
550 & 1 & $0.0004-0.0016$ & 0.71 & $2.1 \times 10^{9}$ & $9.1 \times 10^{7}$ \\
& 2 & $0.0020-0.02$ & -0.55 & $-1.2 \times 10^{6}$ & $1.5 \times 10^{8}$ \\
700 & 1 & $0.0004-0.0016$ & 0.90 & $2.8 \times 10^{9}$ & $3.7 \times 10^{7}$ \\
& 2 & $0.0020-0.01$ & -1.30 & $-2.4 \times 10^{3}$ & $5.4 \times 10^{7}$ \\
800 & 1 & $0.0004-0.0020$ & 0.15 & $3.7 \times 10^{7}$ & $4.3 \times 10^{6}$ \\
& 2 & $0.0024-0.01$ & -1.15 & $-1.8 \times 10^{3}$ & $2.1 \times 10^{7}$ \\
850 & 1 & $0.0004-0.0024$ & 0.64 & $1.4 \times 10^{8}$ & $5.8 \times 10^{6}$ \\
& 2 & $0.0028-0.015$ & -1.21 & $-1.3 \times 10^{3}$ & $1.1 \times 10^{7}$ \\
900 & 1 & $0.0004-0.0028$ & 0.46 & $3.5 \times 10^{7}$ & $2.3 \times 10^{6}$ \\
950 & 2 & $0.0032-0.02$ & -1.05 & $-2.3 \times 10^{3}$ & $5.6 \times 10^{6}$ \\
& 1 & $0.0004-0.0032$ & 0.75 & $9.0 \times 10^{7}$ & $1.2 \times 10^{6}$ \\
& 2 & $0.0036-0.015$ & -1.10 & $-1.1 \times 10^{9}$ & $3.2 \times 10^{6}$ \\
\hline
\end{tabular}

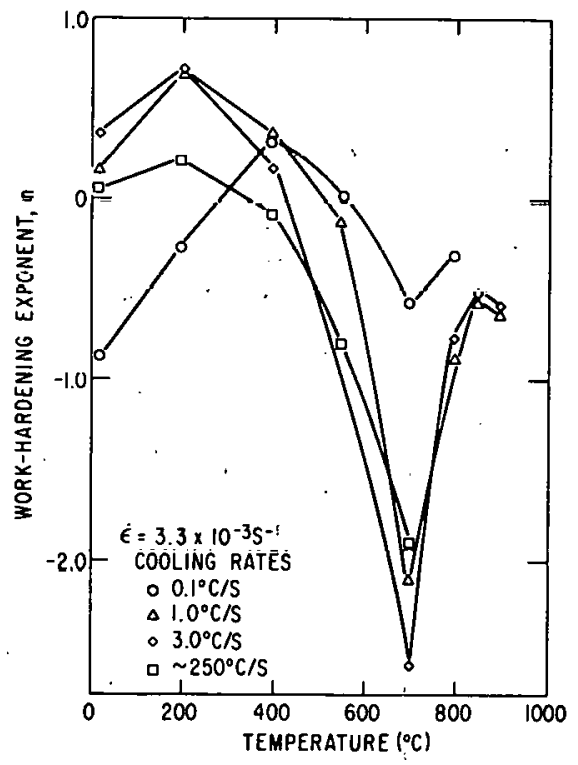

Fig. '12

Temperature Dependence of Work-hardening Exponent of Various Transformed B-phase Zircaloy-4 Structures. ANL Neg. No. 306-77-50 Rev. 1. 


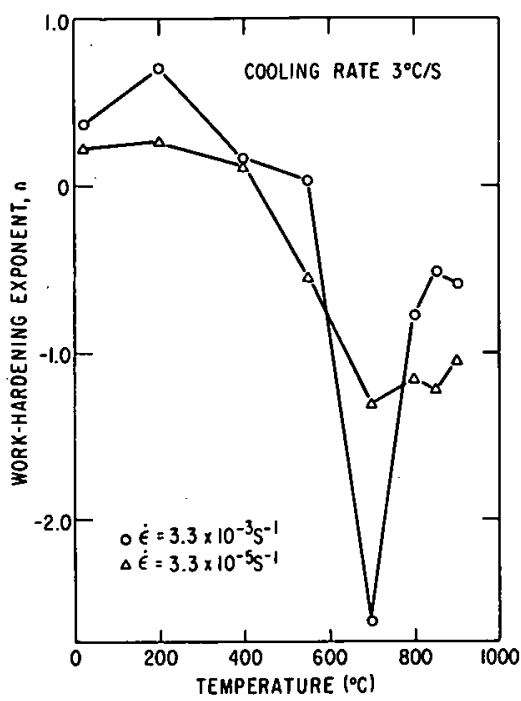

Fig. 73. Work-hardening Exponent of Basketweave-structure Zircaloy -4 as a Function of Temperature at Two Strain Rates. ANL Neg. No. 306-77-51 Rev. 1.

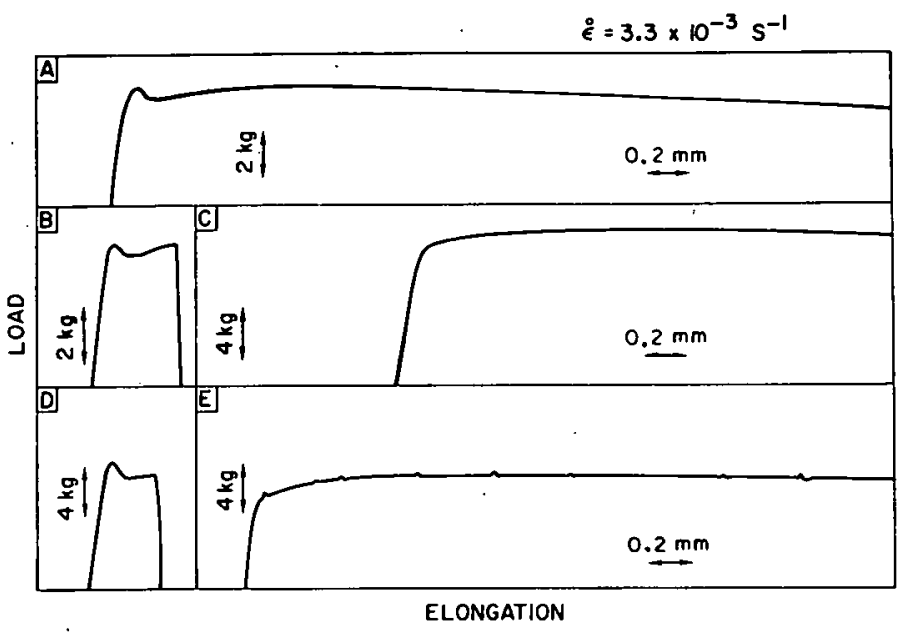

Fig. 74. Partial Load-elongation Curves for Zircaloy-4 Specimens Deformed at $750^{\circ} \mathrm{C}$ after Various Heat Treaments. (A) As-received strained to fracture; (B) as-received, partially strained; (C.) strained to fracture after a 14.4-ks anneal at $750^{\circ} \mathrm{C}$ following $\mathrm{B}$; (D) as-received, partially strained; (E) strained to fracture after a 14.4-ks anneal at $800^{\circ} \mathrm{C}$ following D. Neg. No. MSD-63142.

These results show that the yield point is probably not associated with a breakaway mechanism at $750^{\circ} \mathrm{C}$. Curve $\bar{D}$ represents another specimen prestrained in an identical manner as curve B. However, this specimen was annealed at $800^{\circ} \mathrm{C}$ for $14.4 \mathrm{ks}$ before additional straining at $750^{\circ} \mathrm{C}$. Curve $\mathrm{E}$ shows the resultantload-elongation response. Notice the presence of serrations at fairly regular intervals on the load-elongation curve. This observation implies that some impurity element (or an intermediate phase containing multiple elements) went into solution during the anneal at $800^{\circ} \mathrm{C}$ and then, during subsequent straining at $750^{\circ} \mathrm{C}$, the element (or elements) interacted with dislocations.

Since the yield-point phenomenon occurred at a relatively high temperature $\left(700-750^{\circ} \mathrm{C}\right)$ in both Zircaloy -2 and -4 , substitutional elements are likely to be involved. The observation that the yield point was equally pronounced in the two materials suggests that nickel is not likely to be responsible. The difference in the load-elongation curves after anneals at 750 and $800^{\circ} \mathrm{C}$ suggests that the element responsible for strain aging is in solution at $800^{\circ} \mathrm{C}$ but not at $750^{\circ} \mathrm{C}$. This implies a precipitation or disorder-order phase boundary between 750 and $800^{\circ} \mathrm{C}$. An examination of binary-pháse diagrams $s^{34}$ of zirconium with the three remaining substitutional elements, viz., tin, iron, and chromium, reveals that such a phase boundary exists only in the zirconium-tin system. 
For an alloy of zirconium with $\sim 1.5 \%$ tin, the $\alpha$ phase exists above $\sim 700^{\circ} \mathrm{C}$, and below this temperature, two phases $\left(\alpha+\mathrm{Zr}_{4} \mathrm{Sn}\right.$ ) exist in equilibrium. Whether the presence of tin can cause a yield-point effect depends on the distribution of the tin atoms in the material during deformation. When the as-received material is given a final anneal above $700^{\circ} \mathrm{C}$, tin goes into solution and remains in solution during furnace cooling. When this material is strained for the first time at temperatures between 700 and $750^{\circ} \mathrm{C}$, a yield point is observed. Deformation in this temperature range induces the precipitation or ordering process of tin in the $\alpha$-Zircaloy matrix. Additional annealing below $\sim 800^{\circ} \mathrm{C}$ does not result in the re-solution of the tin, and, thus, the yield point (or serrations on the load-elongation curve) is not observed. However, if the material is annealed at a temperature $>800^{\circ} \mathrm{C}$, tin goes back into solution and dynamic strain-aging effects are observed. Thus, the final heat treatment of the Zircaloy sample and the tin content of the material will determine whether the yield point is observed. These factors may be responsible for the absence of yield points in the data of Luton and Jonas. ${ }^{35}$ We are presently conducting metallographic examinations to determine whether precipitation or ordering of tin actually occurs.

The work-hardening analysis of Zircaloy specimens deformed at $700^{\circ} \mathrm{C}$ and at various strain rates is presented in Tables XVIII-XX and Fig. 75. The yield-point effect was significant at strain rates greater than $10^{-3} \mathrm{~s}^{-1}$ where the work-hardening exponent had positive values. At strain rates lower than $10^{-3} \mathrm{~s}^{-1}$, generally the work-hardening exponent had lower

TABLE XVIII. Least-squares Work-hardening Constants for Longitudinal Zircaloy-2 Specimens Deformed at $700^{\circ} \mathrm{C}$ and Various Strain Rates

\begin{tabular}{lccccc}
\hline $\begin{array}{c}\text { Strain } \\
\begin{array}{c}\text { Rate, } \\
\epsilon, \mathrm{s}^{-1}\end{array}\end{array}$ & $\begin{array}{c}\text { Stage } \\
\text { Number }\end{array}$ & $\begin{array}{c}\text { Strain } \\
\text { Interval }\end{array}$ & $\mathrm{n}$ & $\mathrm{k}, \mathrm{Pa}$ & $\begin{array}{c}\text { Average } \\
\sigma_{0}, \mathrm{~Pa}\end{array}$ \\
\hline $3.3 \times 10^{-2}$ & 2 & $0.013-0.05$ & 0.38 & $4.5 \times 10^{7}$ & $6.6 \times 10^{7}$ \\
$3.3 \times 10^{-3}$ & 2 & $0.007-0.05$ & 0.41 & $3.1 \times 10^{7}$ & $4.8 \times 10^{7}$ \\
$3.3 \times 10^{-4}$ & 2 & $0.0028-0.035$ & 0.35 & $3.1 \times 10^{7}$ & $3.5 \times 10^{7}$ \\
$3.3 \times 10^{-5}$ & 2 & $0.0004-0.014$ & -0.25 & $-1.2 \times 10^{6}$ & $3.2 \times 10^{7}$ \\
$3.3 \times 10^{-6}$ & 2 & $0.0004-0.02$ & -0.30 & $-3.8 \times 10^{5}$ & $2.1 \times 10^{7}$ \\
\hline
\end{tabular}

TAB LE XIX. Least-squares Work-hardening Constants for 5- $\mu \mathrm{m}$ Grain-size Longitudinal Zircaloy-4 Specimens Deformed at $700^{\circ} \mathrm{C}$ and Various Strain Rates

\begin{tabular}{lccccc}
\hline $\begin{array}{l}\text { Strain } \\
\begin{array}{l}\text { Rate, } \\
\varepsilon, \mathrm{s}^{-1}\end{array}\end{array}$ & $\begin{array}{c}\text { Stage } \\
\text { Number }\end{array}$ & $\begin{array}{c}\text { Strain } \\
\text { Interval }\end{array}$ & $\mathbf{n}$ & $\mathbf{k}, \mathrm{Pa}$ & $\begin{array}{c}\text { Average } \\
\sigma_{0}, \mathrm{~Pa}\end{array}$ \\
\hline $3.3 \times 10^{-2}$ & 2 & $0.03-0.05$ & 0.79 & $5.2 \times 10^{7}$ & $7.2 \times 10^{7}$ \\
$3.3 \times 10^{-3}$ & 2 & $0.012-0.05$ & 1.20 & $9.8 \times 10^{7}$ & $.5 .3 \times 10^{7}$ \\
$3.3 \times 10^{-4}$ & 1 & $0.0004-0.006$ & -0.67 & $-8.6 \times 10^{3}$ & $3.9 \times 10^{7}$ \\
& 2 & $0.007-0.025$ & 1.25 & $8.9 \times 10^{7}$ & $3.8 \times 10^{7}$ \\
& 3 & $0.03-0.05$ & 0.58 & $2.3 \times 10^{7}$ & $3.6 \times 10^{7}$ \\
\hline
\end{tabular}


TABLE XX. Least-squares Work-hardening Constants for

11- $\mu \mathrm{m}$ Grain-size Longitudinal Zircaloy-4 Specimens Deformed at $700^{\circ} \mathrm{C}$ and Various Strain Rates

\begin{tabular}{lccccc}
\hline $\begin{array}{l}\text { Strain } \\
\begin{array}{l}\text { Rate, } \\
\dot{\varepsilon}, \mathrm{s}^{-1}\end{array}\end{array}$ & $\begin{array}{c}\text { Stage } \\
\text { Number }\end{array}$ & $\begin{array}{c}\text { Strain } \\
\text { Interval }\end{array}$ & $\mathrm{n}$ & $\mathbf{k}, \mathrm{Pa}$ & $\begin{array}{c}\text { Average, } \\
\sigma_{0}, \mathrm{~Pa}\end{array}$ \\
\hline $3.3 \times 10^{-2}$ & 2 & $0.0004-0.05$ & 0.86 & $8.1 \times 10^{7}$ & $6.8 \times 10^{7}$ \\
$3.3 \times 10^{-3}$ & 2 & $0.006-0.05$ & 0.46 & $3.2 \times 10^{7}$ & $4.3 \times 10^{7}$ \\
$3.3 \times 10^{-4}$ & 1 & $0.0004-0.002$ & -0.53 & $-3.2 \times 10^{4}$ & $3.2 \times 10^{7}$ \\
& 2 & $0.002-0.013$ & 1.03 & $2.7 \times 10^{8}$ & $3.1 \times 10^{7}$ \\
& 3 & $0.013-0.045$ & -0.24 & $-3.6 \times 10^{6}$ & $4.4 \times 10^{7}$ \\
$3.6 \times 10^{-5}$ & 2 & $0.0004-0.04$ & -0.04 & $-2.2 \times 10^{7}$ & $5.6 \times 10^{7}$ \\
$3.3 \times 10^{-6}$ & 1 & $0.0004-0.004$ & -0.63 & $-1.7 \times 10^{4}$ & $1.6 \times 10^{7}$ \\
& 2 & $0.005-0.07$ & 0.50 & $1.0 \times 10^{7}$ & $1.4 \times 10^{7}$ \\
\hline
\end{tabular}

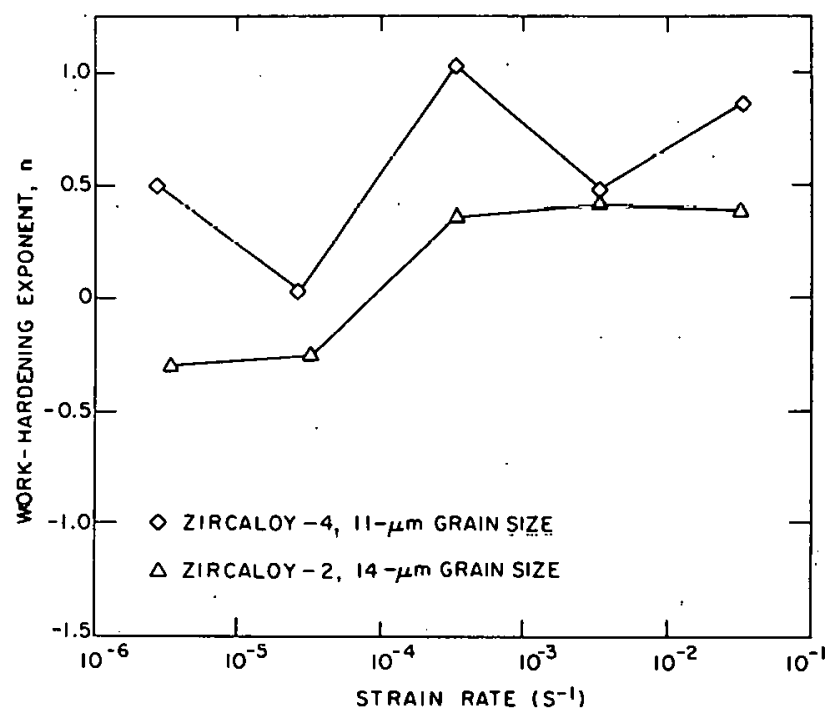

Fig. 75

Strain-rate Dependence of Workhardening Exponent of Zircaloy at $700^{\circ} \mathrm{C}$. ANL Neg. No. $306-77-66$.

values (often negative) and the yield point behavior was absent. Thus, dynamicstrain-aging behavior is associated with peak values of work-hardening exponent.

Figure 76 represents engineering-stress/engincering-strain curves of Zircaloy 4 specimens deformed at $750^{\circ} \mathrm{C}$ after various heat treatments. Figure 74 presents some of these data. The stress-strain curve corresponding to a $0.6-\mathrm{ks}$ hold time at $750^{\circ} \mathrm{C}$ prior to deformation (curve A) shows a load drop only at the start of plastic deformation (yield point); subsequently, there are no load drops or serrations. Curve B represents the stress-strain behavior during final loading of a specimen that was prestrained to 0.02 at $750^{\circ} \mathrm{C}$, unloaded, and held for $14.4 \mathrm{ks}$ at $750^{\circ} \mathrm{C}$ prior to restraining at $750^{\circ} \mathrm{C}$. Note that the stress-strain curve is smooth with no load drops and the yield point is absent. Curve C corresponds to a specimen that was prestrained to 0.02 at $750^{\circ} \mathrm{C}$, unloaded, annealed for $14.4 \mathrm{ks}$ at $800^{\circ} \mathrm{C}$, and then deformed at $750^{\circ} \mathrm{C}$. Note that curve $\mathrm{C}$ has a higher flow-stress level than the two other specimens and shows load drops at regular intervals throughout the 
curve (serrations). This difference in the stress-strain behavior is related to the difference in the work-hardening characteristics presented in Table XXI. All specimens were held for $0.6 \mathrm{ks}$ prior to deformation at the prestraining or restraining temperature. Specimens prestrained and heated to $800^{\circ} \mathrm{C}$ show positive and higher $n$ values indicative of dynamic strain aging. The strainrate sensitivity does not seem to depend on the heat treatment (Fig. 77). . The heat-treatment designation is the same as in Fig. 76.

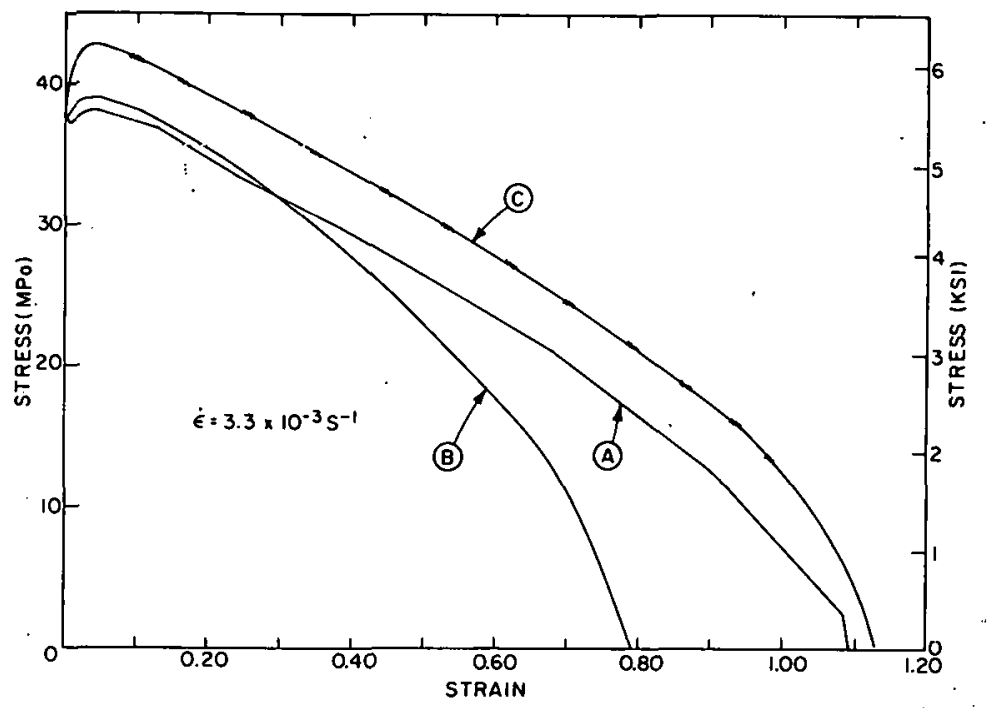

Fig. 76

Engineering-stress/EngineeringStrain Curves for Zircaloy-4 at $750^{\circ} \mathrm{C}$ after Various Heat Treatments. ANL Neg. No. 306-77-75.

TABLE XXI. Least-squares Work-hardening Constants for 11-um Grainsize Longitudinal Zircaloy-4 Specimens Deformed at $750^{\circ} \mathrm{C}$ after. Various Heat Trealmenls; $\ddot{e}=3.3 \times 10^{-3} \mathrm{~s}^{-1}$

\begin{tabular}{cccccc}
\hline $\begin{array}{c}\text { Stage } \\
\text { Number }\end{array}$ & $\begin{array}{c}\text { Strain } \\
\text { Interval }\end{array}$ & $\mathrm{n}$ & $\mathrm{k}, \mathrm{Pa}$ & $\begin{array}{c}\text { Average } \\
0_{0}, \mathrm{~Pa}\end{array}$ & Comment $^{\mathrm{a}}$ \\
\hline 2 & $0.008-0.035$ & 0.68 & $2.8 \times 10^{7}$ & $3.7 \times 10^{7}$ & $\mathrm{~A}$ \\
2 & $0.0004-0.03$ & 0.05 & $2.8 \times 10^{7}$ & $2.4 \times 10^{7}$ & $\mathrm{~B}$ \\
2 & $0.013-0.04$ & 0.08 & $2.5 \times 10^{7}$ & $2.4 \times 10^{7}$ & $\mathrm{C}$ \\
2 & $0.0004-0.04$ & -0.07 & $-1.7 \times 10^{7}$ & $6.2 \times 10^{7}$ & $\mathrm{D}$ \\
2 & $0.0004-0.045$ & 0.08 & $3.1 \times 10^{7}$ & $1.9 \times 10^{7}$ & $\mathrm{E}$ \\
2 & $0.0004-0.04$ & 0.11 & $3.0 \times 10^{7}$ & $2.3 \times 10^{7}$ & $\mathrm{~F}$ \\
2 & $0.0004-0.04$ & 0.19 & $2.1 \times 10^{7}$ & $3.3 \times 10^{7}$ & $\mathrm{G}$ \\
2 & $0.009-0.04$ & 0.46 & $3.1 \times 10^{7}$ & $4.7 \times 10^{7}$ & $\mathrm{H}$ \\
2 & $0.009-0.035$ & 0.49 & $3.2 \times 10^{7}$ & $6.0 \times 10^{7}$ & $\mathrm{I}$ \\
\hline
\end{tabular}

$a_{A}=A s-r e c e i v e d$.

$B=0.02$ prestrain at $750^{\circ} \mathrm{C}$, unload and immediately reload.

$\mathrm{C}-14.4 \mathrm{ks}$ liold time at $750^{\circ} \mathrm{C}$ prior to deformation.

$\mathrm{D}=0.02$ prestrain at $750^{\circ} \mathrm{C}$, unload, $14.4-\mathrm{ks}$ hold at $750^{\circ} \mathrm{C}$.

$E=0.02$ prestrain at $750^{\circ} \mathrm{C}$, unload, $1.2-\mathrm{ks}$ hold at $800^{\circ} \mathrm{C}$.

$F=0.02$ prestrain at $750^{\circ} \mathrm{C}$, unload, $14.4-\mathrm{ks}$ hold at $800^{\circ} \mathrm{C}$.

$\mathrm{G}=0.02$ prestrain at $750^{\circ} \mathrm{C}$, unload, $0.6-\mathrm{ks}$ hold at $800^{\circ} \mathrm{C}$.

$\mathrm{H}=$ Equiaxed homogeneous $\alpha$-phase containing $0.46 \mathrm{wt} \%$ oxygen.

$I=$ Equiaxed homogeneous $\alpha$-phase containing $0.90 \mathrm{wt} \%$ oxygen. 


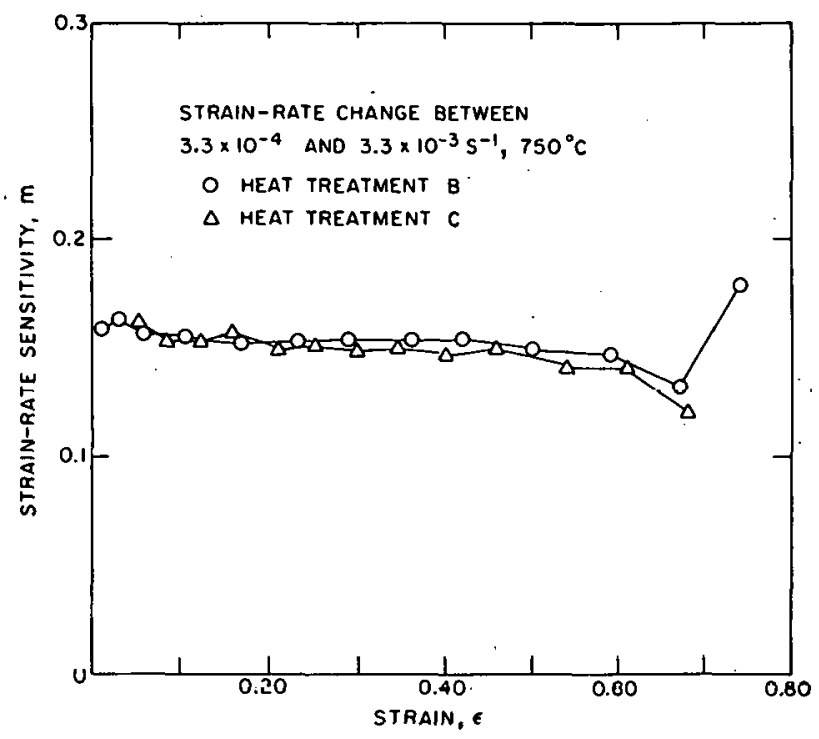

Fig. 77

Strain Dependence of Strain-rate Sensitivity of Zircaloy-4 at $750^{\circ} \mathrm{C}$ after Two Heat Treatments. ANL Neg. No. 306-77-76 Rev. 1.

10. Comparison of Zircaloy-4 Tensile Properties of Stressrelieved Tubing and Recrystallized Sheet

For comparison with the properties of Zircaloy sheet material, uniaxial-tensile tests have been performed on the Zircaloy-4 tubing ${ }^{36}$ that. is used in the ANL biaxial tube-burst tests. and in other Nuclear Regulatory Commission research programs. The microstructure of the material in the as-received stress-relieved condition consists of fine ( $2-\mu \mathrm{m}-$ wide) elongated grains. The wall thickness of the central $10-\mathrm{mm}$ gauge length of the $70-\mathrm{mm}$ long specimens was reduced from 0.635 to $0.432 \mathrm{~mm}$ to ensure that fracture occurred away from the Swageloks that gripped the samples.

Figure 78 shows the temperature dependence of the ultimale tensile strength and the $0.2 \%$ yield stress of the tube material. The properties

Fig. 78

Ultimate Tensile Strength and Yield Stress of Zircaloy-4 Stress-relieved Tube and Recrystallized Sheet as a Function of Temperature. Neg. No. MSD-63395.

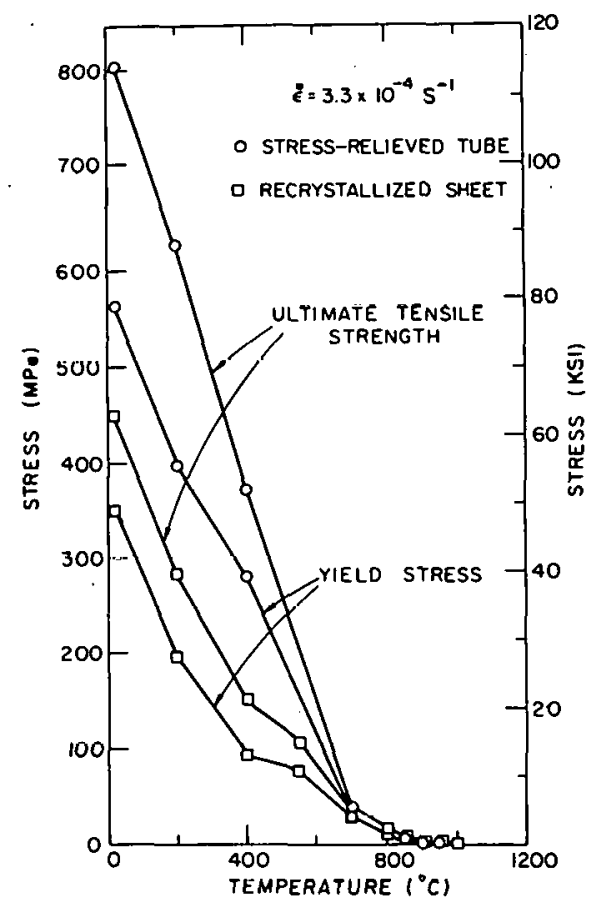


of the recrystallized sheet are shown for comparison. The fine grain size and the elongated grain shape of the cold-worked material are primarily responsible for the higher strength of the tubing below $\sim 800^{\circ} \mathrm{C}$. At higher temperatures, complete recrystallization of the tubing occurs during the tensile test, and the flow stress of the sheet and tube materials is essentially the same.

The total strain of the Zircaloy tube and sheet is plotted in Fig. 79 as function of the deformation temperature. The materials exhibit similar behavior, although the tubing is somewhat less ductile below $\sim 400^{\circ} \mathrm{C}$. and more ductile at higher temperatures. The temperature dependence of the uniform strain of the two materials is shown in Fig. 80 . The uniform strains are comparable below $\sim 850^{\circ} \mathrm{C}$; however, at $900^{\circ} \mathrm{C}$, the tube material exhibits a large strain ( 0.7) that was confirmed by duplicate tests. This behavior can be related to the microstructural changes that occur during deformation. Although the sheet material has an equiaxed grain structure before and during deformation, and grain growth is not significant, the tube recrystallizes and the small equiaxed grains grow considerably during the tensile test. The higher work-hardening rate, as sociated with grain growth, and the grainboundary-sliding deformation mechanism result in a larger uniform strain in the tube material at $\sim 900^{\circ} \mathrm{C}$.

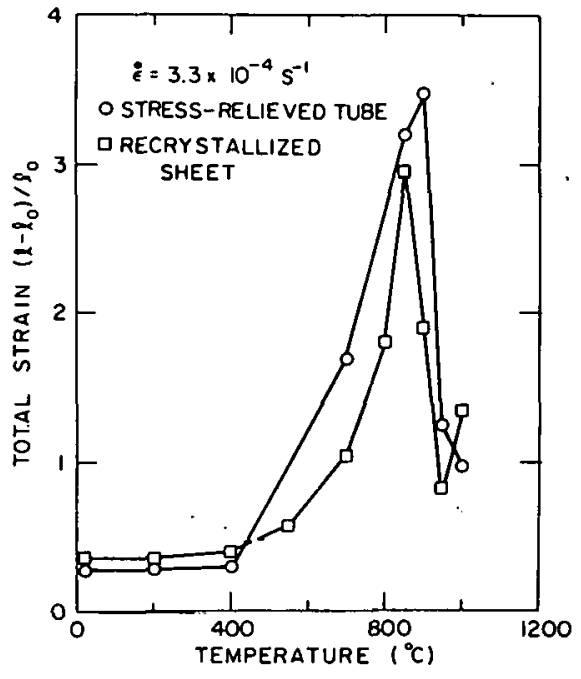

Fig. 79

Total Strain of Zircaloy -4 Tube and Recrystallized sheet as a Function of Temperature. Neg. No. MSD-63396.

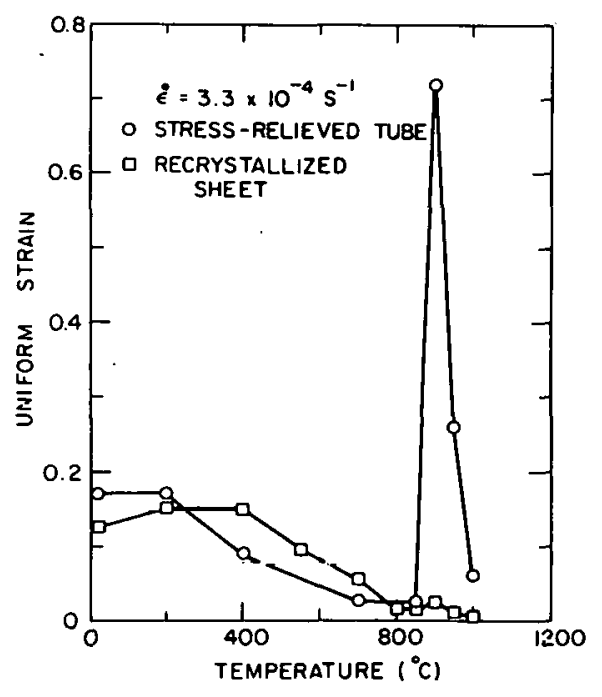

Fig. 80

Uniform Strain of Zircaloy-4 Tube and Recrystallized Sheet as a Function of Temperature. Neg. No. IMSD-63401. 


\section{PROPERTIES OF ZIRCALOY - 4/OXYGEN ALLOYS}

A. Homogeneous Oxygen Distribution

Uniform oxygen distribution was achieved before deformation by homogenizing the oxygen-charged samples at an appropriate temper ature for sufficent time. The effect of oxygen in Zircaloy- 4 on the ultimate tensile strength is shown in Fig. 81 . In $\alpha$-phase Zircaloy-4 (Fig. $81 \mathrm{a}$ ), strengthening due to oxygen is more significant at lower temperatures. Oxygen increases the strength of Zircaloy monotonically at these temperatures. Similar data, presented in Fig. 82 for $\beta$-Zircaloy at higher temperatures $\left(>1200^{\circ} \mathrm{C}\right)$, showed a less systematic trend because with increasing oxygen concentration, the

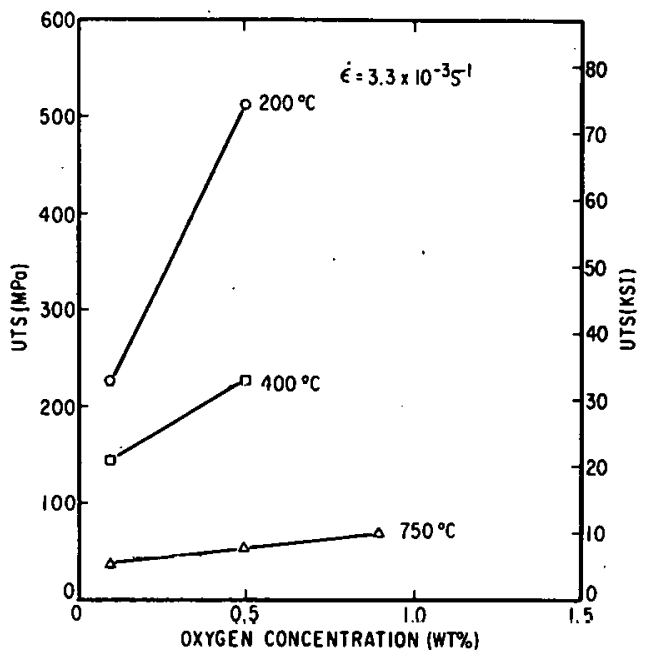

(a)

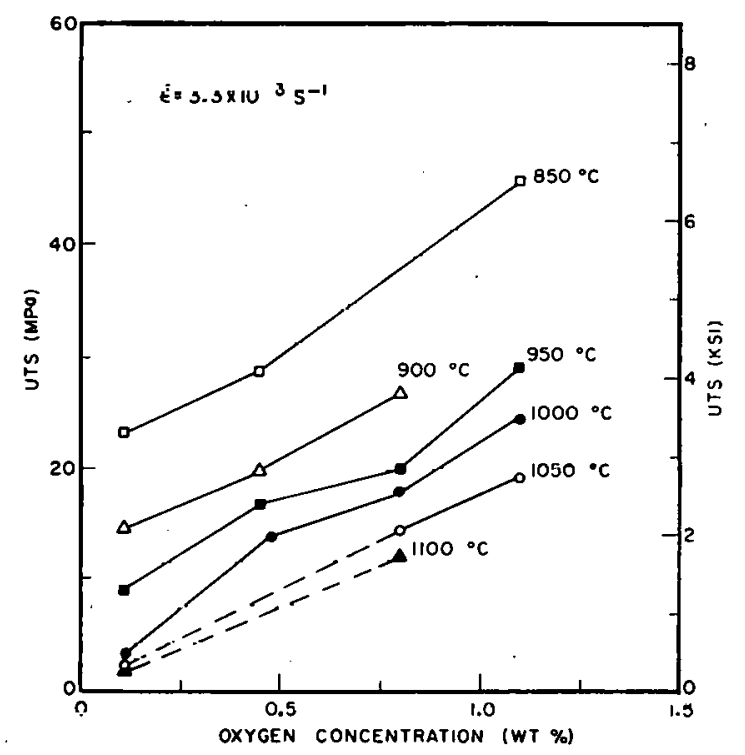

(b)

Fig. 81. Effect of Oxygen on Ultimate Tensile Strength of Zircaloy-4 at Several Temperatures between 200 and $1100^{\circ} \mathrm{C}$. ANL Neg. Nos. 306-77-62 Rev. 1 and 306-76-15.

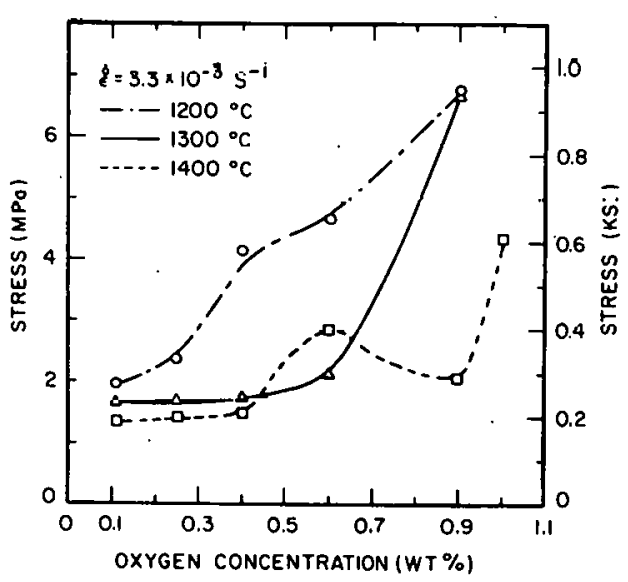

Fig. 82

Variation of Ultimate Tensile Strength of Zircaloy-4 with Oxygen Concentration at 1200,1300 , and $1400^{\circ} \mathrm{C}$. Neg. No. MSU-61848. 
two-phase $(\alpha+\beta)$ region is approached. Moreover, complications associated with the grain growth that occurred during homogenization and deformation of the Zircaloy-oxygen alloys also exist. In some instances, a single grain encompassed the width and thickness of the fracture region of the specimen. Therefore, differences in grain size and orientation may contribute to the complex behavior.

Figures 83 and 84 demonstrate the influence of oxygen on the uniform strain of Zircaloy-4. For temperatures below $750^{\circ} \mathrm{C}$ (Fig. 83a), an increase in the oxygen concentration decreases the uniform strain. Except for the

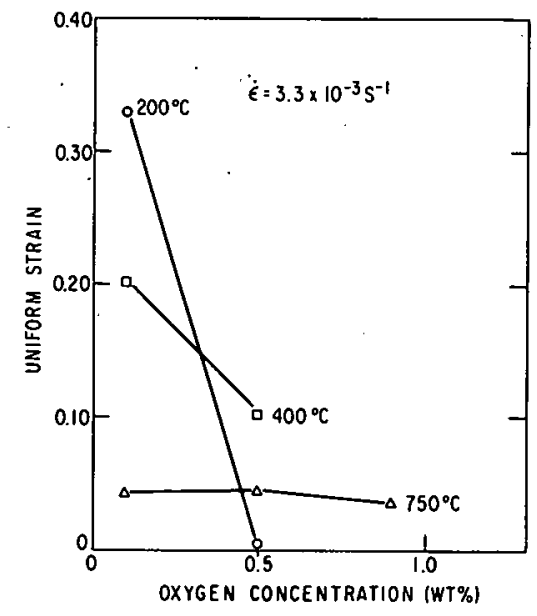

(a)

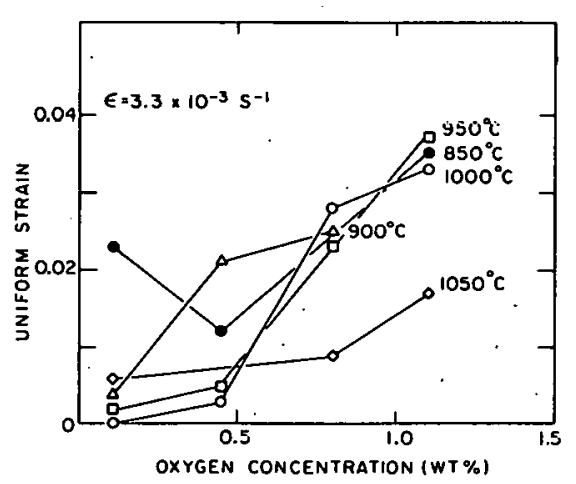

(b)

Fig. 83. Oxygen-concentration Dependence of Uniform Strain of Zircaloy-4 at Several Temperatures: (a) 200, 400, and $750^{\circ} \mathrm{C}$ and (b) $\cdot 850,900,950,1000$, and $1050^{\circ} \mathrm{C}$. ANL Neg. Nos. 306-77-61 Rev. 1 and 306-76-17.

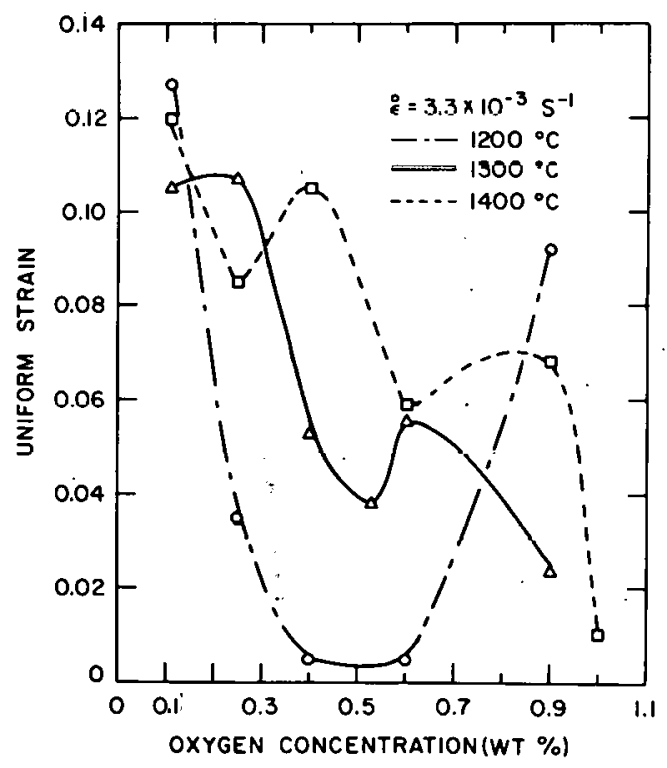

Fig. 84

Oxygen-concentration Dependence of Uniform Strain of Zircaloy-4 at 1200,1300 , and $1400^{\circ} \mathrm{C}$. Neg. No. MSD-61849. 
initial portion of the $850^{\circ} \mathrm{C}$ curve at Fig. $83 \mathrm{~b}$ ( $50.5 \mathrm{wt} \%$ oxygen), the data indicate that the uniform strain increases as the oxygen concentration increases for temperatures between 850 and $1050^{\circ} \mathrm{C}$. This is probably the result of the work-hardening rate, which increases with oxygen concentration. The effect of oxygen on the uniform strain at temperatures $>1200^{\circ} \mathrm{C}$ is complicated (Fig. 84) by the same factors mentioned in connection with Fig. 82.

The effect of oxygen concentration in Zircaloy-4 on the total strain is shown in Figs. 85 and 86. In Fig. 85, the total strain decreases as the oxygen concentration increases, except for the 900,950 , and $1000^{\circ} \mathrm{C}$ curves. The temperature range of the two-phase $(\alpha+\beta)$ field for Zircaloy is altered by oxygen additions; thus, the phase distributions as well as the compositions of the phases must be considered in an attempt to rationalize the results presented in Fig. 85. The influence of oxygen on the total strain at higher temperatures $>1200^{\circ} \mathrm{C}$ (Fig. 86) is complicated by the same factors mentioned earlier.

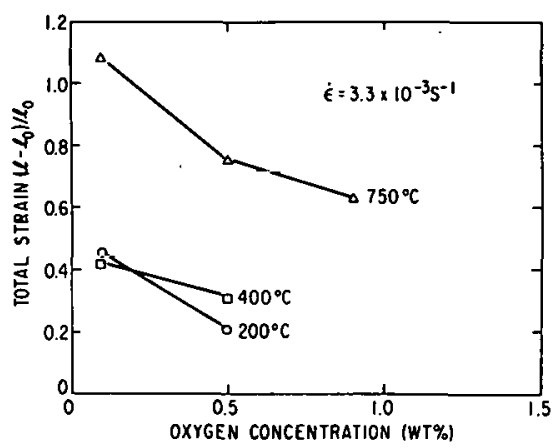

(a)

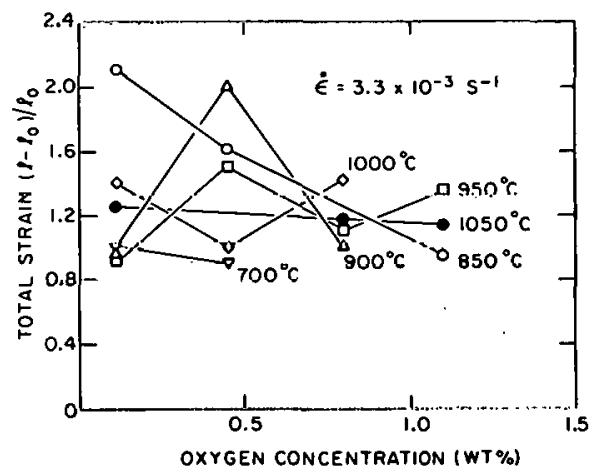

(b)

Fig. 85. Total Strain of Zircaloy-4 as a Function of Oxygen Concentration at Several Temperaturee! (a) 200,100 , and $750^{\circ} \mathrm{C}$ and (b) $700,850,000$, 1000, and $1050^{\circ} \mathrm{C}$. $\Lambda \mathrm{NL} \mathrm{Neg}$. No3. 306 -77 $.80 \mathrm{Rcv} .1$ and $00 \mathrm{G}-7 \mathrm{G}-1 \mathrm{C}$.

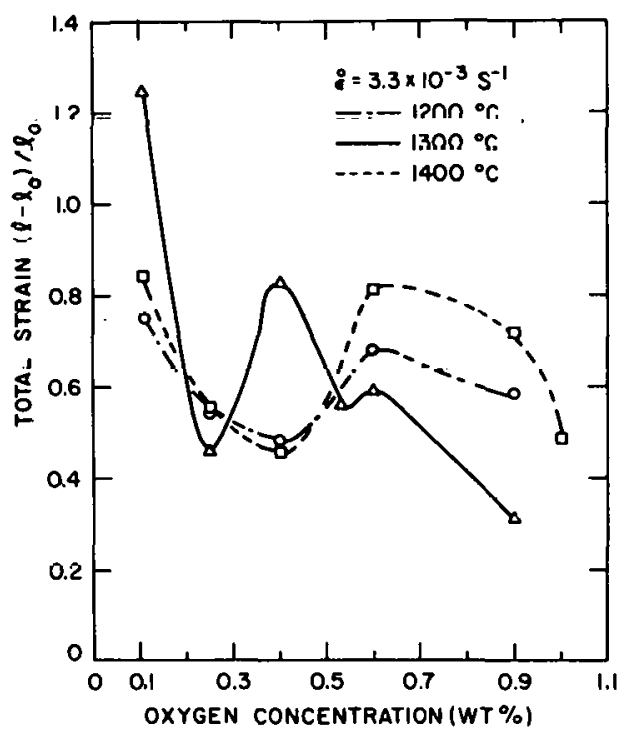

Fig. 86

Effect of Oxygen Concentration on Total Strain of Zircaloy -4 at 1200,1300 , and $1400^{\circ} \mathrm{C}$. Neg. No. MSD -61850 . 


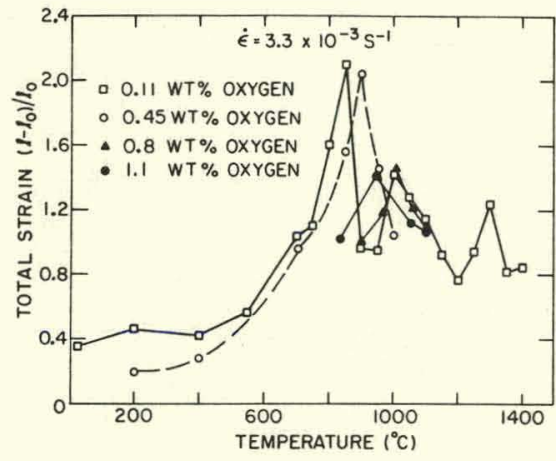

Fig. 87. Effect of Oxygen on Temperature Dependence of Total Strain of Zircaloy-4. ANL Neg. No. 306-76-18 Rev. 1.
Figure 87 shows the influence of oxygen on the total strain of Zircaloy-4 as a function of temperature. As the oxygen concentration increases, the low-temperature superplastic elongation peak (i.e., at $850^{\circ} \mathrm{C}$ for 0.11 wt $\%$ oxygen) shifts to higher temperatures. This observation is consistent with the Zircaloy-oxygen phase diagram (Fig. 88) since the $\alpha /(\alpha+\beta)$ boundary shifts to higher temperatures with increasing oxygen concentration. Figure 87 also shows that the amount of elongation at the peak decreases as the oxygen concentration increases (i.e., 2.1 total strain at 0.11 wt $\%$ oxygen, compared with 1.4 total strain at 1.1 wt $\%$ oxygen). This decrease in elongation occurs because oxygen reduces the ductility of both the $\alpha$ and $\beta$ phases. We could not determine the influence of oxygen on the

high-temperature superplastic elongation peak (i.e., the peak at $\sim 1000^{\circ} \mathrm{C}$ for 0.11 wt $\%$ oxygen) because of the long homogenization times required at temperatures below $\sim 80^{\circ} \mathrm{C}$ to obtain a small equiaxed grain structure with large oxygen concentrations.

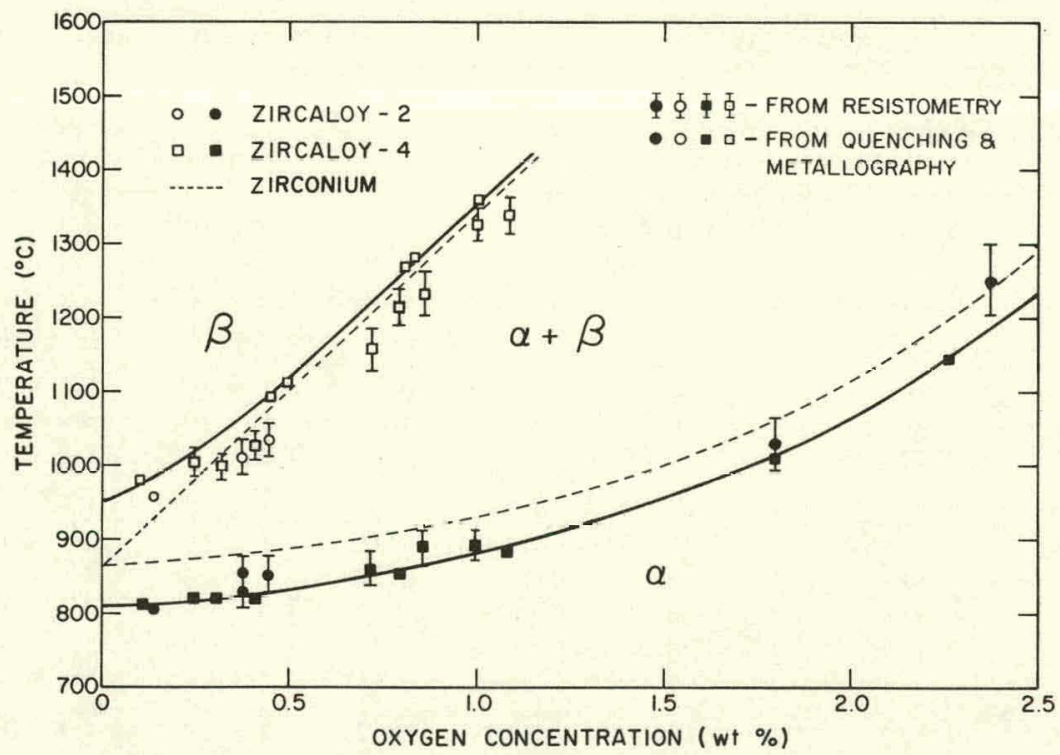

Fig. 88. Pseudobinary Zircaloy-Oxygen Phase Diagram Determined from Metallographic and Resistivity Measurements. Dashed line corresponds to the zirconium-oxygen system. ANL Neg. No. 306-76-82 Rev. 1.

Figure 89 shows an SEM fractograph of a Zircaloy-4 specimen, with 2.3 wt $\%$ oxygen, fractured at $850^{\circ} \mathrm{C}$. At $850^{\circ} \mathrm{C}, \mathrm{Zircaloy}$ with this oxygen content has a single-phase $\alpha$ structure. The $\alpha$ phase exhibits transgranular cleavage fracture as a result of the high oxygen concentration. The river patterns are clearly visible in the grains. 


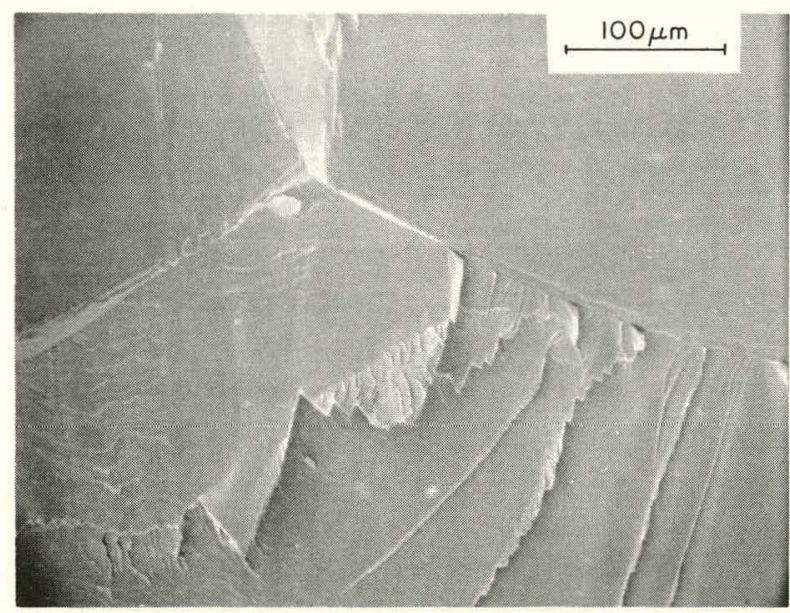

Fig. 89

SEM Fractograph of Zircaloy-4 Specimen with $2.3 \mathrm{wt} \%$ Oxygen Fractured at $850^{\circ} \mathrm{C} ; \dot{\epsilon}=3.3 \times 10^{-3} \mathrm{~s}^{-1}$. ANL Neg. No. 306-75-132 Rev. 1.

The effect of oxygen on the work-hardening behavior of Zircaloy-4 is shown in Tables XXII-XXV and Figs. 90-95. The data in Tables XXII-XXIV and Figs. 90-94 refer to specimens that were cooled through the two-phase region after charging and/or a homogenization anneal before the mechanical testing. Therefore, these specimens contained nonequiaxed tranformed $\beta$-phase grains with various degrees of oxygen (and probably other alloying elements) redistribution.

TABLE XXII. Least-squares Work-hardening Constants for Longitudinal Specimens of Zircaloy-4/Oxygen Alloys; $\dot{\varepsilon}=3.3 \times 10^{-3} \mathrm{~s}^{-1}$

\begin{tabular}{|c|c|c|c|c|c|c|}
\hline$\underset{{ }^{\circ} \mathrm{C}}{\text { Temp }}$ & $\begin{array}{c}\text { Oxygen, } \\
\text { wt } \%\end{array}$ & $\begin{array}{l}\text { Stage } \\
\text { Number }\end{array}$ & $\begin{array}{c}\text { Strain } \\
\text { Interval }\end{array}$ & $\mathrm{n}$ & $\mathrm{k}, \mathrm{Pa}$ & $\begin{array}{c}\text { Average } \\
\sigma_{n}, \mathrm{~Pa}\end{array}$ \\
\hline 1000 & 0.25 & $\begin{array}{l}1 \\
2 \\
1 \\
2\end{array}$ & $\begin{array}{l}0.0004-0.0024 \\
0.0028-0.0090 \\
0.00010 .0028 \\
0.0032-0.0150\end{array}$ & $\begin{array}{r}0.71 \\
-2.20 \\
0.78 \\
-0.59\end{array}$ & $\begin{array}{r}2.3 \times 10^{8} \\
-2.6 \times 10^{0} \\
1.2 \times 10^{8} \\
-4.5 \times 10^{4}\end{array}$ & $\begin{array}{l}4.3 \times 10^{6} \\
8.7 \times 10^{6} \\
1.1 \times 10^{7} \\
1.3 \times 10^{7}\end{array}$ \\
\hline 1100 & 0.25 & $\begin{array}{l}1 \\
? \\
2\end{array}$ & $\begin{array}{l}0.0004-0.0016 \\
\cap \cap 02.0-\cap \cap 050 \\
0.0004-0.0700\end{array}$ & $\begin{array}{r}0.21 \\
-0.82 \\
0.21\end{array}$ & $\begin{array}{r}2.4 \times 10^{7} \\
-? .8 \times 10^{3} \\
1.5 \times 10^{6}\end{array}$ & $\begin{array}{r}-1.6 \times 10^{6} \\
54 \times 10^{6} \\
2.5 \times 10^{6}\end{array}$ \\
\hline 1200 & 0.24 & $\begin{array}{l}1 \\
2 \\
1 \\
2 \\
1 \\
2\end{array}$ & $\begin{array}{l}0.0004-0.0050 \\
0.0060-0.0250 \\
0.0004-0.0020 \\
0.0024-0.0060 \\
0.0004-0.0020 \\
0.0020-0.0050\end{array}$ & $\begin{array}{r}0.26 \\
-0.46 \\
0.68 \\
-3.50 \\
0.75 \\
-0.56\end{array}$ & $\begin{array}{l}2.3 \times 10^{6} \\
-3.1 \times 10^{4} \\
9.6 \times 10^{7} \\
-1.7 \times 10^{-4} \\
1.1 \times 10^{7} \\
-2.9 \times 10^{3}\end{array}$ & $\begin{array}{l}1.6 \times 10^{6} \\
2.5 \times 10^{6} \\
2.2 \times 10^{6} \\
4.1 \times 10^{6} \\
4.4 \times 10^{6} \\
4.6 \times 10^{6}\end{array}$ \\
\hline 1300 & $\begin{array}{l}0.60 \\
0.92\end{array}$ & $\begin{array}{l}2 \\
3 \\
2 \\
2 \\
3\end{array}$ & $\begin{array}{l}0.0004-0.0140 \\
0.0150-0.0500 \\
0.0004-0.0500 \\
0.0004-0.0040 \\
0.0050-0.0200\end{array}$ & $\begin{array}{r}0.92 \\
0.11 \\
0.14 \\
0.82 \\
-1.50\end{array}$ & $\begin{array}{r}6.1 \times 10^{6} \\
1.5 \times 10^{6} \\
2.1 \times 10^{6} \\
1.8 \times 10^{8} \\
-4.2 \times 10^{2}\end{array}$ & $\begin{array}{l}1.5 \times 10^{6} \\
7.0 \times 10^{5} \\
7.1 \times 10^{5} \\
3.4 \times 10^{6} \\
6.8 \times 10^{6}\end{array}$ \\
\hline 1400 & 0.27 & $\begin{array}{l}2 \\
3 \\
2 \\
3 \\
2 \\
3 \\
2 \\
3\end{array}$ & $\begin{array}{l}0.0012-0.0150 \\
0.0200-0.0700 \\
0.0004-0.0040 \\
0.0050-0.0900 \\
0.0004-0.0060 \\
0.0070-0.1300 \\
0.0004-0.0032 \\
0.0036-0.0080\end{array}$ & $\begin{array}{r}1.10 \\
-0.31 \\
0.87 \\
0.19 \\
0.93 \\
0.20 \\
0.50 \\
-1.90\end{array}$ & $\begin{array}{r}1.2 \times 10^{7} \\
-1.4 \times 10^{5} \\
1.4 \times 10^{7} \\
1.5 \times 10^{6} \\
3.4 \times 10^{7} \\
3.9 \times 10^{6} \\
1.4 \times 10^{7} \\
-5.6 \times 10^{0}\end{array}$ & $\begin{array}{l}1.1 \times 10^{6} \\
1.8 \times 10^{6} \\
1.0 \times 10^{6} \\
5.9 \times 10^{5} \\
2.4 \times 10^{6} \\
1.3 \times 10^{6} \\
3.2 \times 10^{6} \\
4.3 \times 10^{6}\end{array}$ \\
\hline
\end{tabular}


TABLE XXIII. Least-squares Work-hardening Constants for Longitudinal Specimens of Zircaloy-4/Oxygen Alloys; $\dot{\varepsilon}=3.3 \times 10^{-4} \mathrm{~s}^{-1}$

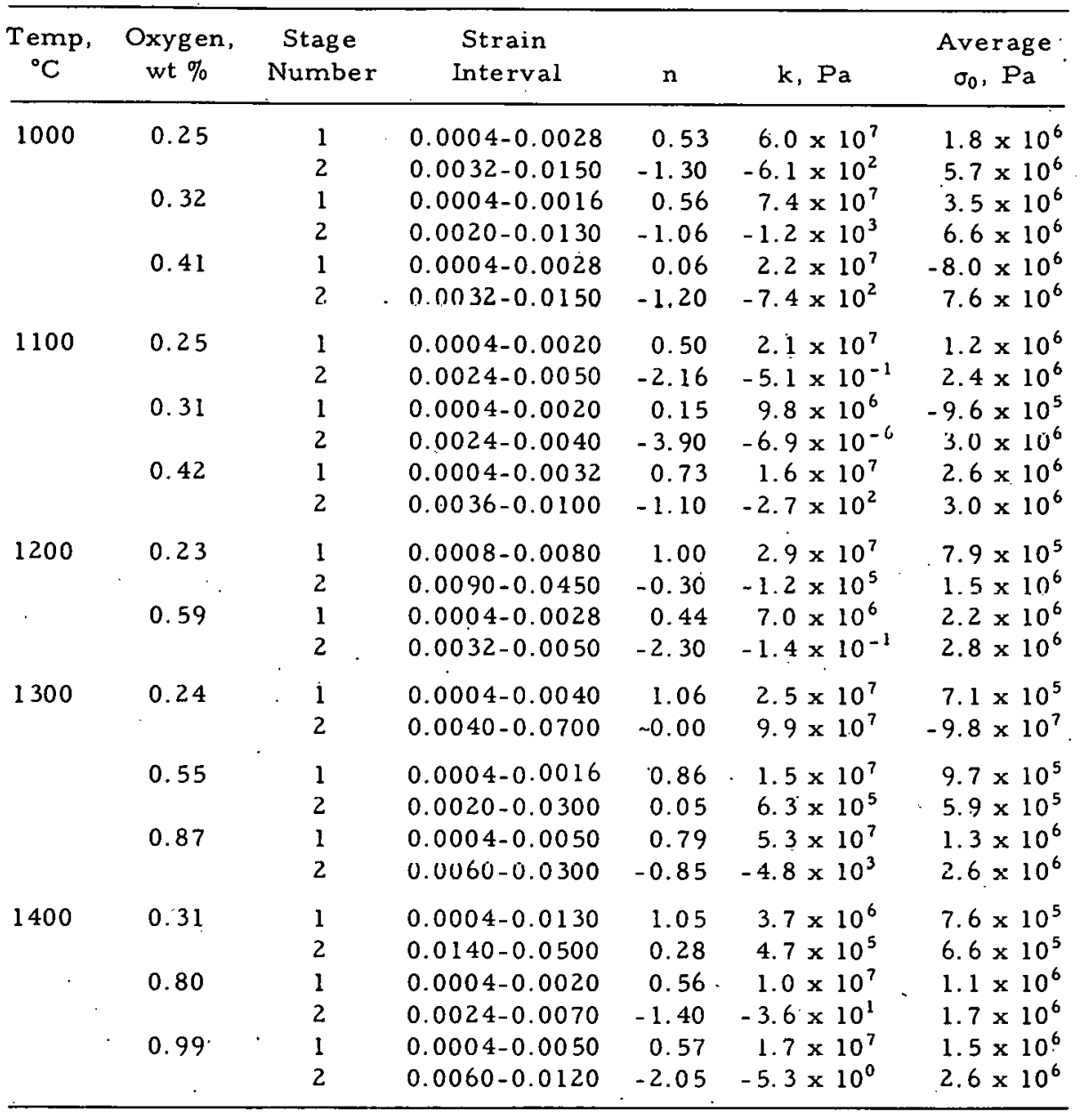

TABLE XXIV. Least-squares Work-hardening Constants for Longitudinal Specimens of Zircaloy-4/Oxygen Alloys; $\dot{\epsilon}=3.3 \times 10^{-5} \mathrm{~s}^{-1}$

\begin{tabular}{|c|c|c|c|c|c|c|}
\hline $\begin{array}{l}\text { Temp } \\
{ }^{\circ} \mathrm{C}\end{array}$ & $\begin{array}{l}\text { Oxygen, } \\
\text { wt } \%\end{array}$ & $\begin{array}{c}\text { Stage } \\
\text { Number }\end{array}$ & $\begin{array}{l}\text { Strain } \\
\text { Interval }\end{array}$ & $\mathbf{n}$ & $\mathrm{k}, \mathrm{Pa}$ & $\begin{array}{c}\text { Average } \\
\sigma_{0}, \mathrm{~Pa}\end{array}$ \\
\hline 1000 & 0.23 & $\begin{array}{l}1 \\
2 \\
1 \\
2\end{array}$ & $\begin{array}{l}0.0004-0.0028 \\
0.0032-0.0060 \\
0.0004-0.0024 \\
0.0028-0.0500\end{array}$ & $\begin{array}{r}0.85 \\
-0.97 \\
0.63 \\
-0.16\end{array}$ & $\begin{array}{r}5.1 \times 10^{7} \\
-1.3 \times 10^{3} \\
6.7 \times 10^{7} \\
-1.4 \times 10^{6}\end{array}$ & $\begin{array}{l}1.2 \times 10^{6} \\
1.9 \times 10^{6} \\
1.6 \times 10^{6} \\
7.0 \times 10^{6}\end{array}$ \\
\hline 1100 & 0.43 & $\begin{array}{l}1 \\
2\end{array}$ & $\begin{array}{l}0.0004-0.0032 \\
0.0036-0.0250\end{array}$ & $\begin{array}{r}0.76 \\
-0.72\end{array}$ & $\begin{array}{r}3.4 \times 10^{7} \\
-8.7 \times 10^{3}\end{array}$ & $\begin{array}{l}2.1 \times 10^{6} \\
3.1 \times 10^{6}\end{array}$ \\
\hline 1200 & 0.43 & $\begin{array}{l}1 \\
2\end{array}$ & $\begin{array}{l}0.0004-0.0036 \\
0.0040-0.0070\end{array}$ & $\begin{array}{r}0.84 \\
-1.30\end{array}$ & $\begin{array}{r}2.1 \times 10^{7} \\
-1.1 \times 10^{2}\end{array}$ & $\begin{array}{l}1.2 \times 10^{6} \\
1.5 \times 10^{6}\end{array}$ \\
\hline 1300 & 0.79 & $\begin{array}{r}1 \\
2 \\
-\quad 1 \\
2\end{array}$ & $\begin{array}{l}0.0004-0.0032 \\
0.0036-0.0300 \\
0.0004-0.0040 \\
0.0050-0.0450\end{array}$ & $\begin{array}{r}0.83 \\
-0.37 \\
0.86 \\
-0.50\end{array}$ & $\begin{array}{r}2.6 \times 10^{7} \\
-5.9 \times 10^{4} \\
3.5 \times 10^{7} \\
-2.7 \times 10^{4}\end{array}$ & $\begin{array}{l}4.4 \times 10^{5} \\
1.2 \times 10^{6} \\
1.7 \times 10^{6} \\
2.5 \times 10^{6}\end{array}$ \\
\hline 1400 & 0.31 & $\begin{array}{l}1 \\
2 \\
1 \\
2\end{array}$ & $\begin{array}{l}0.0004-0.0150 \\
0.0200-0.1100 \\
0.0004-0.0040 \\
0.0050-0.02 .50\end{array}$ & $\begin{array}{r}1.05 \\
0.46 \\
0.96 \\
-0.21\end{array}$ & $\begin{array}{r}1.9 \times 10^{6} \\
6.2 \times 10^{5} \\
1.0 \times 10^{8} \\
-6.8 \times 10^{5}\end{array}$ & $\begin{array}{l}3.8 \times 10^{5} \\
3.2 \times 10^{5} \\
5.9 \times 10^{5} \\
3.3 \times 10^{6}\end{array}$ \\
\hline
\end{tabular}


TABLE XXV. Effect of Oxygen Concentration on Least-squares Workhardening Constants of Longitudinal Equiaxed $\alpha$-phase Zircaloy -4 Specimens; $\dot{\varepsilon}=3.3 \times 10^{-3} \mathrm{~s}^{-1}$

\begin{tabular}{|c|c|c|c|c|c|c|}
\hline $\begin{array}{l}\text { Temp, } \\
{ }^{\circ} \mathrm{C}\end{array}$ & $\begin{array}{c}\text { Oxygen } \\
\text { Concentration, } \\
\text { wt } \%\end{array}$ & $\begin{array}{c}\text { Stage } \\
\text { Number }\end{array}$ & $\begin{array}{c}\text { Strain } \\
\text { Interval }\end{array}$ & n & $k, P a$ & $\begin{array}{c}\text { Average } \\
\sigma_{0}, \mathrm{~Pa}\end{array}$ \\
\hline 200 & 0.50 & 2 & $0: 0004-0.0024$ & -0.13 & $-4.7 \times 10^{7}$ & $6.2 \times 10^{8}$ \\
\hline 400 & 0.50 & 2 & $0.0080-0.09$ & 0.88 & $5.4 \times 10^{8}$ & $1.9 \times 10^{8}$ \\
\hline 750 & 0.46 & 2 & $0.009-0.04$ & 0.46 & $3.1 \times 10^{7}$ & $4.7 \times 10^{7}$ \\
\hline 850 & 0.46 & 2 & $0.0004-0.014$ & -0.49 & $-1.1 \times 10^{5}$ & $2.9 \times 10^{7}$ \\
\hline 900 & 0.45 & $\begin{array}{l}1 \\
2\end{array}$ & $\begin{array}{l}0.0004-0.002 \\
0.0024-0.015\end{array}$ & $\begin{array}{r}0.20 \\
-0.57\end{array}$ & $\begin{array}{r}2.5 \times 10^{7} \\
-5.0 \times 10^{4}\end{array}$ & $\begin{array}{l}1.1 \times 10^{7} \\
2.0 \times 10^{7}\end{array}$ \\
\hline 950 & 0.47 & 2 & $0.0004-0.005$ & -0.44 & $-6.1 \times 10^{4}$ & $1.7 \times 10^{7}$ \\
\hline 1000 & 0.49 & 2 & $0.0004-0.0036$ & -1.00 & $-7.6 \times 10^{2}$ & $1.4 \times 10^{7}$ \\
\hline 1050 & 0.50 & 2 & $0.0004-0.0036$ & -1.50 & $-1.4 \times 10^{1}$ & $1.1 \times 10^{7}$ \\
\hline 1100 & 0.50 & 2. & $0.0004-0.002$ & -1.10 & $-3.5 \times 10^{2}$ & $8.8 \times 10^{6}$ \\
\hline 750 & 0.90 & 2 & $0,009-0.035$ & 0.49 & $37 \times 1 n^{7}$ & $6.0 \times 10^{7}$ \\
\hline 900 & 0.80 & 2 & $0.0004-0.02$ & -0.18 & $-1.3 \times 10^{6}$ & $2.9 \times 10^{7}$ \\
\hline 950 & 0.82 & $\begin{array}{l}1 \\
2\end{array}$ & $\begin{array}{l}0.0004-0.0012 \\
0.0016-0.02\end{array}$ & $\begin{array}{r}0.67 \\
-0.45\end{array}$ & $\begin{array}{r}2.7 \times 10^{8} \\
-2.4 \times 10^{5}\end{array}$ & $\begin{array}{l}1.3 \times 10^{7} \\
2.1 \times 10^{7}\end{array}$ \\
\hline 1000 & 0.81 & $\begin{array}{l}1 \\
2\end{array}$ & $\begin{array}{l}0.0004-0.0012 \\
0.0016-0.02\end{array}$ & $\begin{array}{r}0.75 \\
-0.41\end{array}$ & $\begin{array}{r}4.0 \times 10^{8} \\
-2.6 \times 10^{5}\end{array}$ & $\begin{array}{l}1.3 \times 10^{7} \\
1.9 \times 10^{7}\end{array}$ \\
\hline 1050 & 0.82 & 2 & $0.0004-0.008$ & -0.37 & $-2.8 \times 10^{5}$ & $1.6 \times 10^{7}$ \\
\hline 1100 & 0.82 & $\begin{array}{l}2 \\
3\end{array}$ & $\begin{array}{r}0.0004-0.005 \\
0.006-0.011\end{array}$ & $\begin{array}{r}0.83 \\
-3.70\end{array}$ & $\begin{array}{l}2.1 \times 10^{8} \\
4.0 \times 10^{-3}\end{array}$ & $\begin{array}{l}8.6 \times 10^{6} \\
1.2 \times 10^{7}\end{array}$ \\
\hline 850 & $1.15^{\circ}$ & 2 & $0.011=0.03$ & 0.30 & $1.8 \times 10^{7}$ & $1.0 \times 10^{7}$ \\
\hline 950 & 1.14 & $\begin{array}{l}1 \\
2\end{array}$ & $\begin{array}{c}0.0004-0.0036 \\
0.004-0.03\end{array}$ & $\begin{array}{r}0.82 \\
-0.89\end{array}$ & $\begin{array}{r}5.9 \times 10^{8} \\
-3.5 \times 10^{4}\end{array}$ & $\begin{array}{l}1.9 \times 10^{7} \\
3.0 \times 10^{7}\end{array}$ \\
\hline 1000 & 1.14 & 2 & $0.0004-0.025$ & -0.08 & $-1.1 \times 10^{7}$ & $4 n \times 1 n^{7}$ \\
\hline 1050 & 1.10 & $\begin{array}{l}1 \\
2\end{array}$ & $\begin{array}{l}0.0004-0.0024 \\
0.0028-0.02\end{array}$ & $\begin{array}{r}0.23 \\
-0.47\end{array}$ & $\begin{array}{r}3.1 \times 10^{7} \\
-1.9 \times 10^{5}\end{array}$ & $\begin{array}{l}9.4 \times 10^{6} \\
2.0 \times 10^{7}\end{array}$ \\
\hline
\end{tabular}

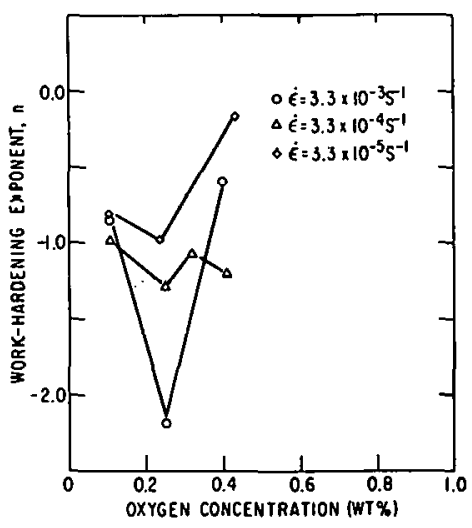

Fig. 90

Work-hardening Exponent of Zircaloy -4 at $1000^{\circ} \mathrm{C}$ as a Function of Oxygen Concentration. ANL Neg. No. 306-77-60 Rev. 1.

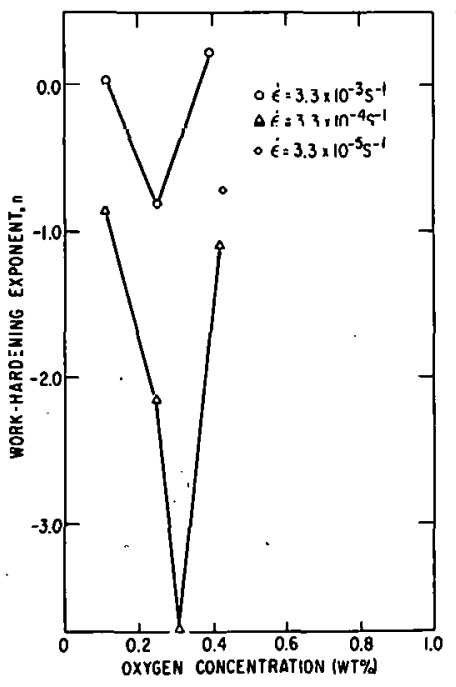

Fig. 91

Work-hardening Exponent of Zircaloy-4 at $1100^{\circ} \mathrm{C}$ as a Function of Oxygen Concentration. ANL Neg. No. 306-77-55 Rev. 1. 


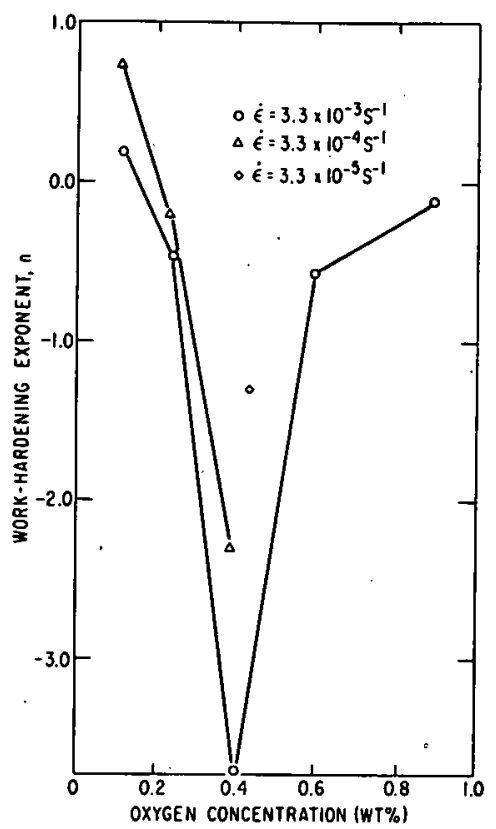

Fig. 92

Work-hardening Exponent of Zircaloy-4 at $1200^{\circ} \mathrm{C}$ as a Function of Oxygen Concentration. ANL Neg. No. 306-77-56 Rev. 1.

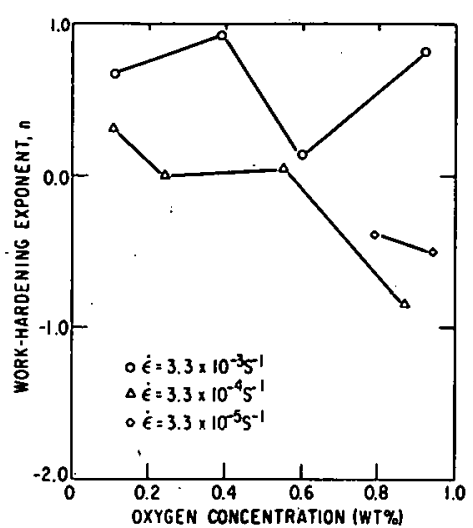

Fig. 93

Work-hardening Exponent of Zircaloy-4 at $1300^{\circ} \mathrm{C}$ as a Function of Oxygen Concentration. ANL Neg. No. 306-77-68 Rev. 1.

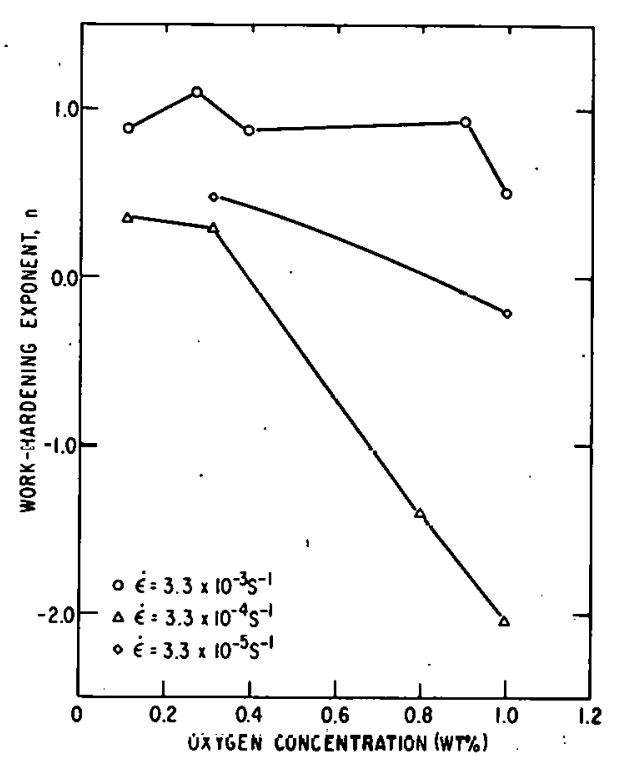

f'ig. $\dot{9} 4$

Work-hardening Exponent of Zircaloy-4 at $1400^{\circ} \mathrm{C}$ as a Function of Oxygen Concentration. ANL Neg. No. 306-77-53 Rev. 1.

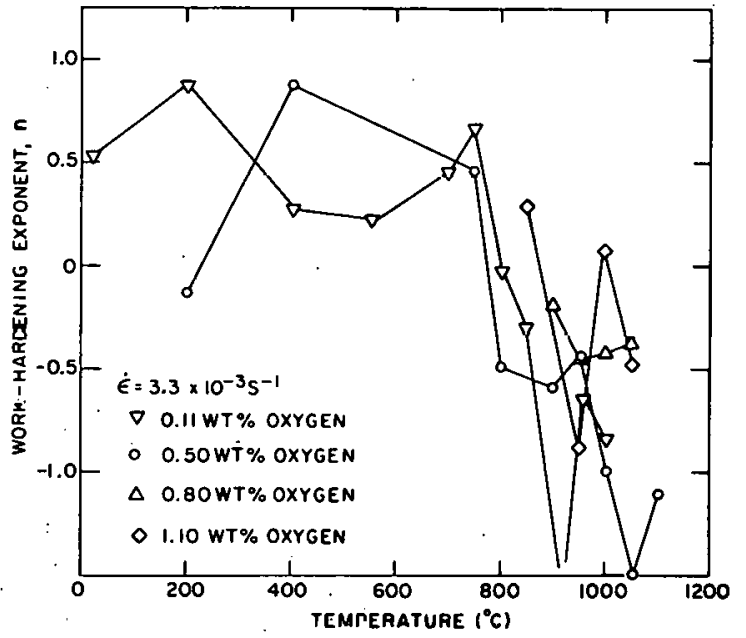

Fig. 95

Temperature Dependence of Work-hardening Exponent of Zircaloy-4 with Several Oxygen Concentrations. ANL Neg. No. 306-77-77 Rev. 1. 
The work-hardening rate of Zircaloy-oxygen alloys depends on the influence of oxygen on the microstructure of the material. From the phase diagram (Fig. 88), an increase in the oxygen concentration changes the microstructure of the alloy from $\beta$ to $\alpha+\beta$ at temperatures above $1000^{\circ} \mathrm{C}$. The data in Tables XXII-XXIV indicate that small additions of oxygen increase the workhardening rate of $\beta$-phase Zircaloy as long as the composition of the alloy is not close to the two-phase boundary. Near the two-phase boundary the workhardening rate shows a minimum (negative value of $\mathrm{n}$ ). The data in Figs. 90-92 all show a minimum value of $\mathrm{n}$ at intermediate oxygen concentrations (0.25$0.4 \mathrm{wt} \%$ oxygen), and the oxygen concentration at which the minimum occurs increases as the temperature increases from 1000 to $1200^{\circ} \mathrm{C}$. In Figs. 93 and 94 , the minimum is not readily apparent, since the oxygen concentration range is away from $\beta /(\alpha+\beta)$ phase boundary. With a higher work-hardening rate, the Consideré criterion for maximum load point on the load-elongation curve $\mathrm{d} \sigma / \mathrm{d} \varepsilon=\sigma$, is satisfied at the highest strain. Therefore, the uniform strain behavior in Fig. 84 is consistent with Figs. 92-94.

The influence of strain rate on the work-hardening rate is complicated by the concomitant grain growth that occurs during deformation. At slower strain rates, the grain-boundary sliding component is expected to be more significant, which may lower the work-hardening rate. However, the longer test times result in significant grain growth, which tends to increase the workhardening rate. These opposing factors operate to various degrees and result in a complicated behavior.

The data in Table XXV and Fig. 95 were obtained from specimens that were oxygen-charged and homogenized in the $\alpha$-phase region and therefore had an equiaxed grain structure at the start of deformation. Consistent with the phase diagram, the region of negative work-hardening exponent shifts to higher temperature with increasing oxygen concentration.

Figures 96-100 show the effect of strain on the strain-rate sensitivity of Zircaloy-4 containing different oxygen concentrations in the range of

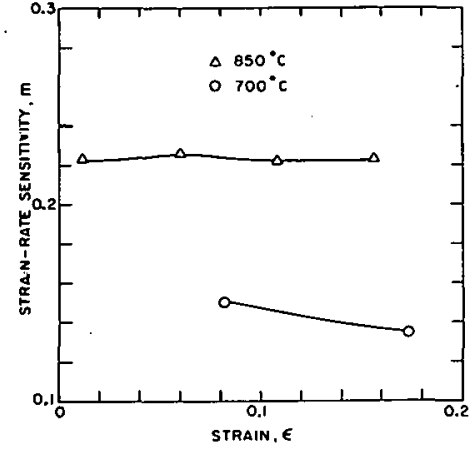

Fig. 96. Strain Dependence of Strainrate Sensitivity of Zircaloy-4 with $0.5 \mathrm{wt} \%$ Oxygen at 700 and $850^{\circ} \mathrm{C}$. Strain-rate change between $3.3 \times 10^{-4}$ and $3.3 \times$ $10^{-3} \mathrm{~s}^{-1}$. ANL Neg. No. 306-75-196 Rev. 1.

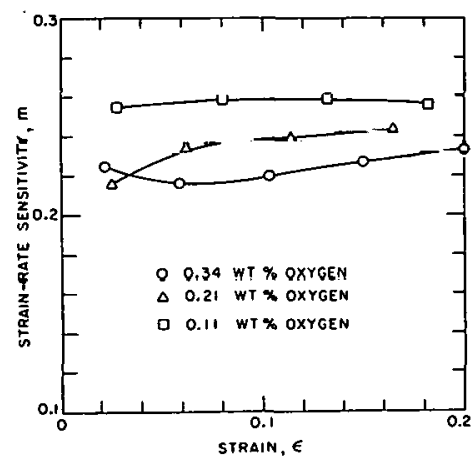

Fig. 97. Effect of Strain on Strain-rate Sensitivity of Zircaloy-4 at $1000^{\circ} \mathrm{C}$ with $0.11,0.21$, and 0.34 wt \% Oxygen. Strainrate change between $3.3 \times 10^{-4}$ and $3.3 \times 10-3 \mathrm{~s}-1$. ANL Neg. No. 306-75-197 Rev. 1. 


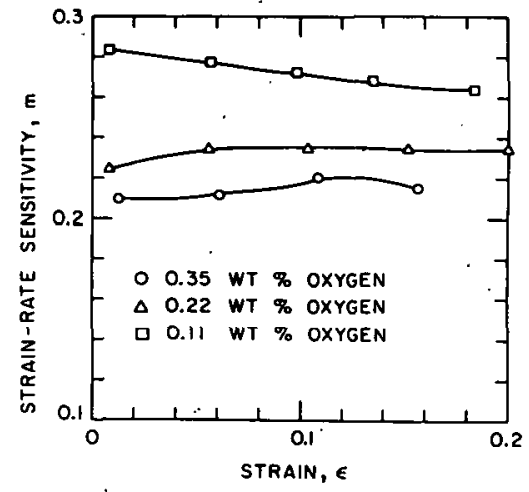

Fig. 98

Effect of Strain on Strain-rate Sensitivity of Zircaloy-4 with 0.11 , 0.22 , and 0.35 wt $\%$ Oxygen at $1200^{\circ} \mathrm{C}$. Strain-rate Change between $3.3 \times 10^{-4}$ and $3.3 \times 10^{-3} \mathrm{~s}^{-1}$. ANL Neg. No. 306-75-193 Rev. 1

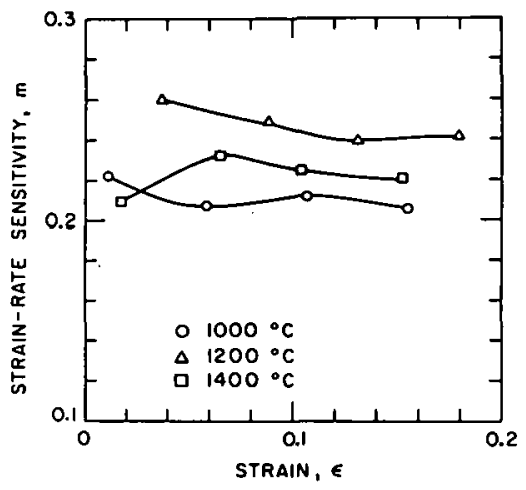

Fig. 90

Effect of Strain on Strain-rate Sensitivity of Zircaloy -4 with 0.25 wt $\%$ Oxygen at 1000 , 1200 , and $1400^{\circ} \mathrm{C}$. Strain-rate change between $3.3 \times 10^{-4}$ and $3.3 \times 10^{-3} \mathrm{~s}^{-1}$. ANL Neg. No. 306-75-191 Rev. 1.

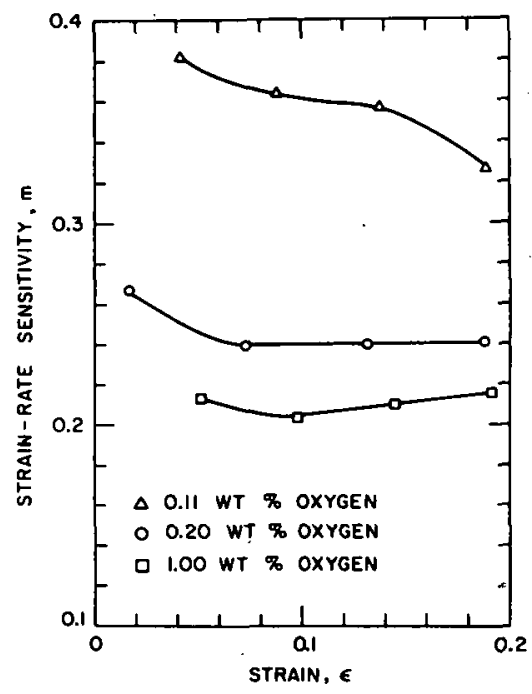

Fig. 100

Strain Dependence of Strain-rate Sensitivity of Zircaloy-4 with 0.11 , 0.2 , and $1.0 \mathrm{wt} \%$ Oxygen at $1400^{\circ} \mathrm{C}$. Strain-rate change between $3.3 \mathrm{x}$ $10^{-4}$ and $3.3 \times 10^{-3} \mathrm{~s}^{-1}$. ANL Neg. No. 306-75-189 Rev. 1.

$0.11-1.0$ wt $\%$ for temperatures between 700 and $1400^{\circ} \mathrm{C}$. Near the lowtemperature peak in the curve of total elongation versus temperature, i.e., $850^{\circ} \mathrm{C}$ in Fig. 21 , small additions of oxygen do not decrease the strain-rate sensitivity of $Z$ ircaloy. The $m$ values in Fig. 96 for an alloy with 0.5 wt $\%$ oxygen are essentially the same as those for the as-received material with 0.11 wt $\%$ oxygen (see Fig. 24). Similar to the behavior of as-received material, the strain-rate sensitivity of Zircaloy with 0.5 wt \% oxygen is not straindependent at $850^{\circ} \mathrm{C}$ (near the peak on the strain-temperature diagram), but decreases as the strain increases at $700^{\circ} \mathrm{C}$ (away from the superplastic ellongation peak).

At higher temperatures $\left(\geq 1000^{\circ} \mathrm{C}\right)$, an increase in the oxygen concentration decreases the strain-rate sensitivity to the extent that the superplastic elongation behavior is diminished or eliminated. Grain growth during homogenization of the oxygen-charged specimens may also contribute to the decrease in elongation. Figure 101 shows the oxygen dependence of the strain-rate sensitivity parameter $\mathrm{m}$ for temperatures of 1200,1300 , and $1400^{\circ} \mathrm{C}$. These results are consistent. with Zircaloy tensile data obtained in an air environment ${ }^{37}$ in which oxidation during the test eliminated the superplastic elongation behavior at temperatures $>1000^{\circ} \mathrm{C}$.

B. Composite Material with Oxygen Gradients in $\alpha$ and $\beta$ Phases

Since the duration of a hypothetical LOCA in an LWR is quite short, steam oxidation of the $\mathrm{Zircaloy}$ cladding will produce $\mathrm{ZrO}_{2} / \alpha / \beta, \mathrm{ZrO}_{2} / \alpha /(\alpha+\beta)$, 


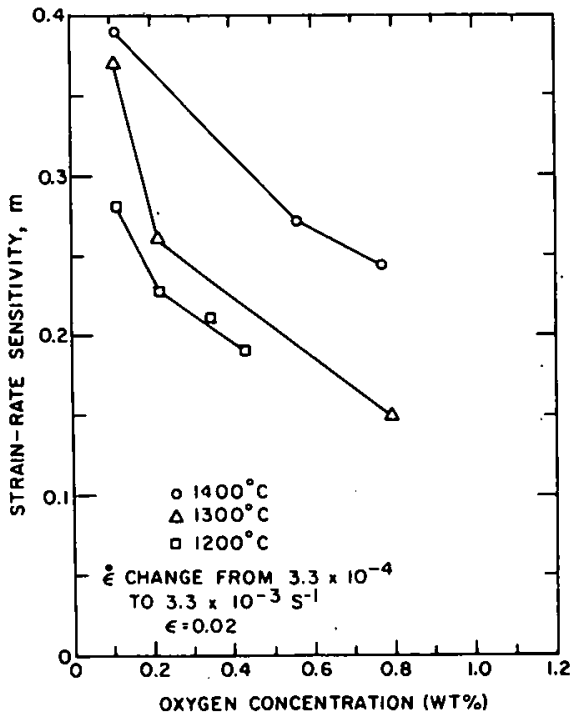

Fig. 101

üxygen-concentratiun Dependence of Strain-rate Sensitivity of Zircaloy-4 at 1200,1300 , and $1400^{\circ} \mathrm{C}$. ANL Neg. No. 306-76-9 Rev, 1 . or $\mathrm{ZrO}_{2} / \alpha$ composites with oxygen-concentration gradients in each phase. Although an understanding of the influence of oxygen on the mechanical properties of the individual $\alpha$ and $\beta$ phases will be useful in interpreting the mechanical properties of composite materials, it is essential to conduct tensile tests on composites.

Tensile specimens of the as-received Zircaloy -4 (with 0.11 wt $\%$ oxygen) were heated in oxygen for $0.72 \mathrm{ks}$ at $800^{\circ} \mathrm{C}$ to increase the oxygen level to 0.8 wt $\%$. This charging process produced a surface oxide layer and $\alpha$ phase with a steep oxygen-concentration gradient. The oxide surface layer was quite thin, so that $\sim 95 \%$ of the total. thirkness was $x$ phasc. However, the number of phase layers and/or the oxygen-concentration gradient in each case can change during hightemperature deformation in the Instrom furnace. Metallographic examinations of the fractured. specimens were used to determine the final layer thicknesses. Similarly, composite specimens with different total oxygen concentrations were produced with the following charging conditions: $\left[0.45\right.$ wt $\%\left(700^{\circ} \mathrm{C}, 0.72 \mathrm{ks}\right) ; 1.12$ wt $\%\left(800^{\circ} \mathrm{C}, 2.7 \mathrm{ks}\right)$; and 1.9 wt $\%\left(900^{\circ} \mathrm{C}, 0.9 \mathrm{ks}\right]$.

Figure 102 compares the temperature dependence of the total strain for the homogenized and composite specimens. Figure 103 shows the

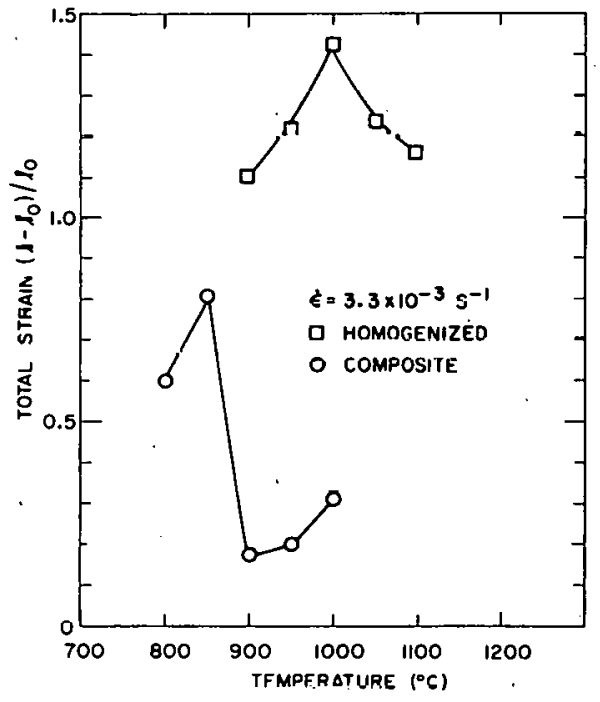

Fig. 102

Temperature Dependence of Total Strain of Homogenized and Composite Zircaloy 4 with 0.8 wt $\%$ Oxygen. ANL Neg. No. 306-76-23 Rev. 1.

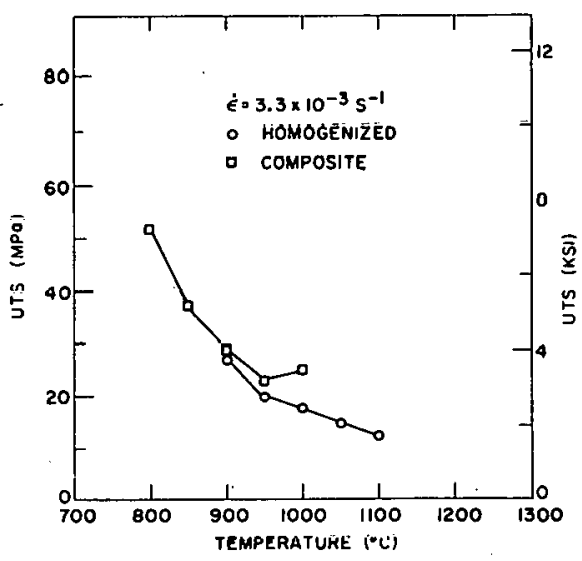

Fig. 103

Ultimate Tensile Strength as a Function of Temperature for Homogenized and Composite Zircaloy-4 with 0.8 wt \% Oxygen. ANL Neg. No. 306-76-22. 
corresponding comparison of the ultimate tensile strength as a function of temperature. The composition and volume fraction of each phase in the homogenized specimens at the test temperature varied according to the phase diagram, although no macroscopic oxygen gradient existed across the specimen. The structures of the composite specimens at the deformation temperature were as follows: oxide $|\alpha|$ oxide (below $800^{\circ} \mathrm{C}$ ), oxide $|\alpha /(\alpha+\beta) / \alpha|$ oxide (between 800 and $1000^{\circ} \mathrm{C}$, with smaller thicknesses of the oxide and $\alpha$ layers as the temperature increased), and $\alpha / \beta / \alpha$ (above $1000^{\circ} \mathrm{C}$ ). An oxygenconcentration gradient was present in each phase. Metallographic examination of the deformed samples revealed that the oxide surface was cracked severely below $1000^{\circ} \mathrm{C}$ and the oxide $/ \alpha$ interface was separated at several places. Thus, only the $\alpha$ and $\beta$ layers of the composite were load-bearing. The results in Fig. 102 demonstrate that the presence of a brittle layer on the surface decreases the total strain (ductility) of Zircaloy considerably, although the ultimate tensile strength does not change significantly (Fig. 103).

Figures 104-107 show the strain dependence of the strain-rate sensitivity of Zircaloy-oxide composites for various total oxygen contents at 800 , 850,900 , and $1100^{\circ} \mathrm{C}$, respectively. At $800^{\circ} \mathrm{C}$ (Fig. 104), the strain-rate sensitivity is relatively independent of strain; however, the magnitude of the strain-rate sensitivity decreases as the oxygen concentration increases. At 850 and $900^{\circ} \mathrm{C}$ (Figs. 105 and 106), the strain-rate sensitivity increases with strain due to the superplastic characteristics of the load-bearing $\alpha$ phase or

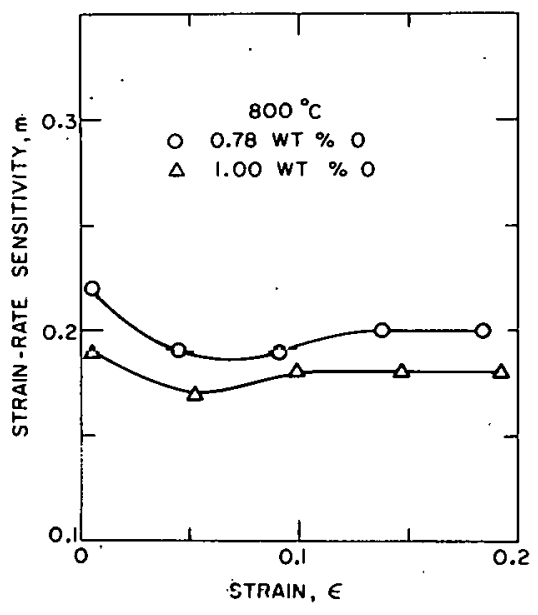

Fig. 104

Strain Dependence of Strain-rate Sensitivity of Zircaloy-4/Oxide Composites with 0.78 and 1.00 wt \% Total Oxygen at $800^{\circ} \mathrm{C}$. Strainrate change from $3.3 \times 10^{-4}$ to $3.3 \times$ $10^{-3} \mathrm{~s}^{-1}$. Neg. No. MSD-62579.

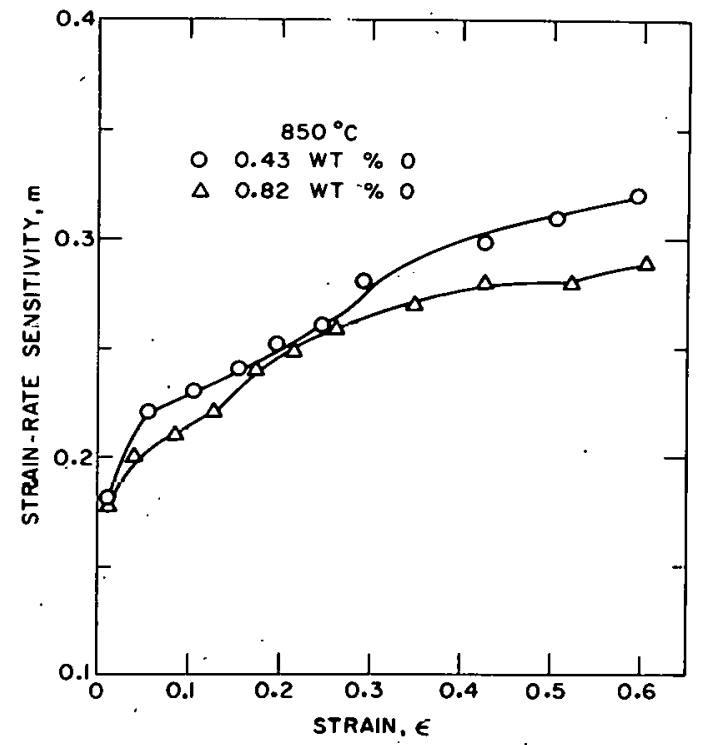

Fig. 105

Strain-rate Sensitivity as a Function of Strain for Zircaloy-4/Oxide Composites with 0.43 and 0.82 wt $\%$ Total Oxygen at $850^{\circ} \mathrm{C}$. Strainrate change from $3.3 \times 10^{-4}$ to $3.3 \times 10^{-3} \mathrm{~s}^{-1}$. Neg. No. MSD-62585. 


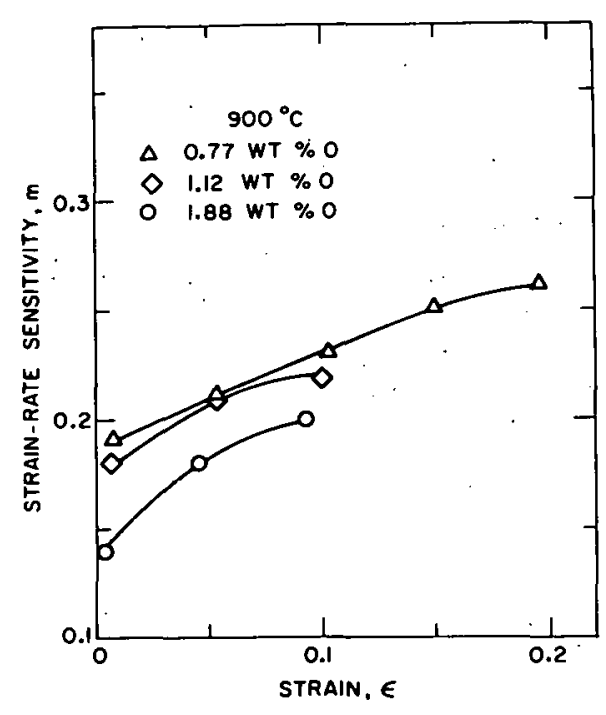

Fig. 106

Strain-rate Sensitivity as a Function of Strain for Zircaloy-4/Oxide Composites with $0.77,1.12$, and 1.88 wt $\%$ Total Oxygen at $900^{\circ} \mathrm{C}$. Strain-rate change from $3.3 \times 10^{-4}$ to $3.3 \times 10^{-3} \mathrm{~s}^{-1}$. Neg. No. MSD-62587.

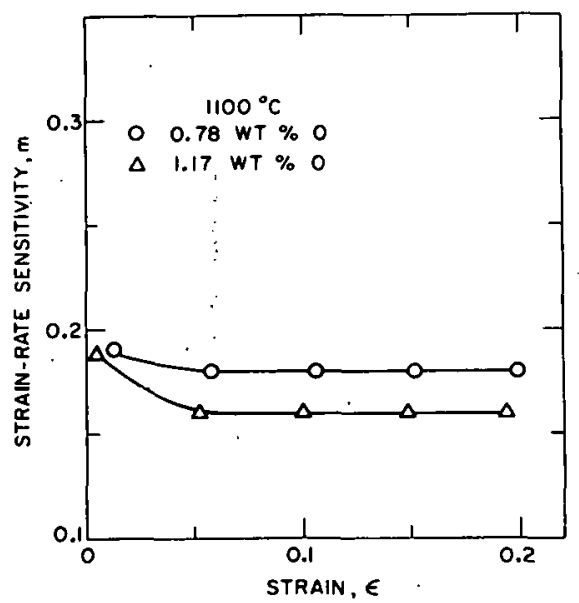

Fig. 107

Strain Dependence of Strain-late Sensitivity of Zircaloy $-4 / O x i d e$ Composites with 0.78 and 1.17 wt \% Total Oxygen at $1100^{\circ} \mathrm{C}$. Strain-rate change from $3.3 \times 10^{-4}$ to $3.3 \times 10^{-3} \mathrm{~s}^{-1}$. Neg. No. MSD-62589.

$\alpha+\beta$ layer. At $1100^{\circ} \mathrm{C}$, the superplastic effect diminishes and the strain dependence of strain-rate sensitivity shows a normal behavior, i.e., an initial

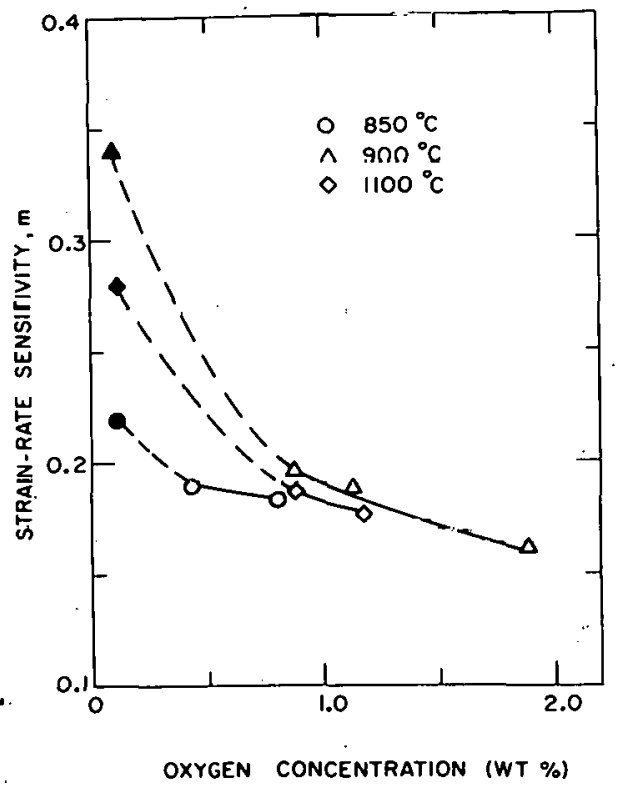

Fig. 108

Strain-rate Sensitivity of Zircaloy-4/ Oxide Composites as a Function of Total Oxygen Concentration at 850,900 , and $1100^{\circ} \mathrm{C}$. Strain-rate change from $3.3 \mathrm{x}$ $10^{-4}$ to $3.3 \times 10^{-3} \mathrm{~s}^{-1} ; \epsilon=0.02$. Neg. No. MSD-62584. decrease in the $m$ value, which then becomes independent of strain (Fig. 107).

Figure 108 indicates the effect of total oxygen concentration on the strain-rate sensitivity of Zircaloy-4/oxide composites. The data points for an oxygen concentration of 0.11 wt $\%$ rorrespond to the as-received homogeneous material. At all three temperatures, the strainrate sensitivity decreases as the oxygen concentration increases. These results do not agree with measurements by Bockek, ${ }^{37}$ which showed that the magnitude of the strain-rate sensitivity of Zircaloy-oxide composites increased during simultaneous oxidation and deformation in an air environment.

Specimens with oxygen concentrations $<1.75$ wt $\%$ were prepared by charging oxygen into the as-received $11-\mu \mathrm{m}$ grain-size Zircaloy-4 material at temperatures below the $\alpha$-phase boundary (i.e., below $805^{\circ} \mathrm{C}$ ). Thus, before heat. ing in the mechanical testing furnace, the specimens had an oxide $|\alpha|$ oxide composite structure. For mechanical-test temperatures $<805^{\circ} \mathrm{C}$, this 
composite structure was maintained during deformation with only minor changes in the oxygen gradient in the $\alpha$ phase because of the low diffusivity of oxygen. As the deformation temperature was increased into the $\alpha+\beta$ $\left(>805^{\circ} \mathrm{C}\right)$ and $\beta$-phase $\left(>980^{\circ} \mathrm{C}\right)$ regions, the composite structure changed significantly during deformation due to the large diffusivity of oxygen in the $\beta$ phase. When the deformation temperature increases above $1000^{\circ} \mathrm{C}$, the oxide layer dissolves and the relative thicknesses of the $\alpha$ and $\beta$ layers vary as functions of holding time, deformation time, and deformation temperature.

The microstructures of deformed composite specimens showed significant differences for deformation temperatures below and above $1000^{\circ} \mathrm{C}$. In specimens deformed below $\sim 1000^{\circ} \mathrm{C}$, both the oxide and $\alpha$ layers exhibited significant cracking (Fig. 109). In specimens deformed above $1000^{\circ} \mathrm{C}$, the oxide layer in most cases was absent and the $\alpha$ layer did not show cracking (Fig. 110).

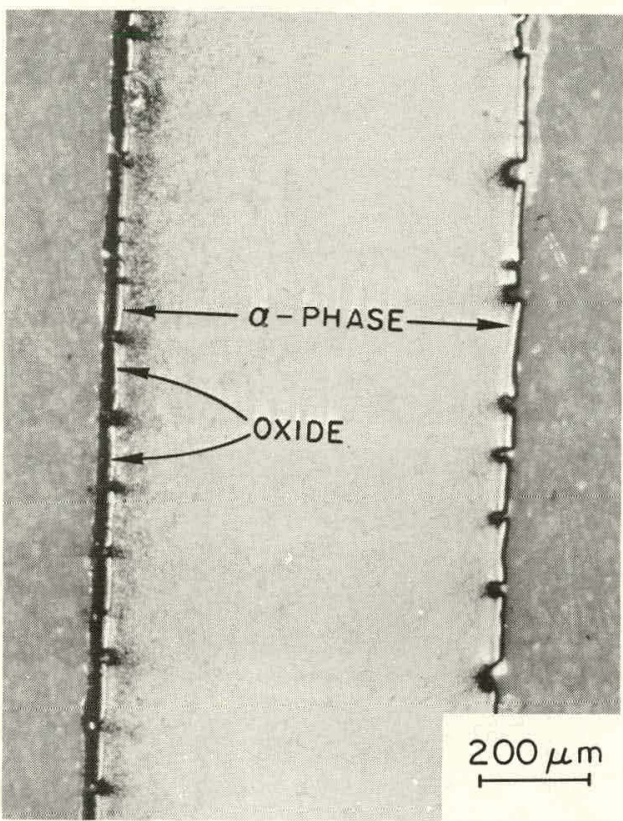

Fig. 109

Microstructure of Zircaloy-4/Oxide Composite Specimen Deformed at $800^{\circ} \mathrm{C}$ Showing Cracks in Oxide and $\alpha$ Layers. ANL Neg. No. 306-77-89 Rev. 1.

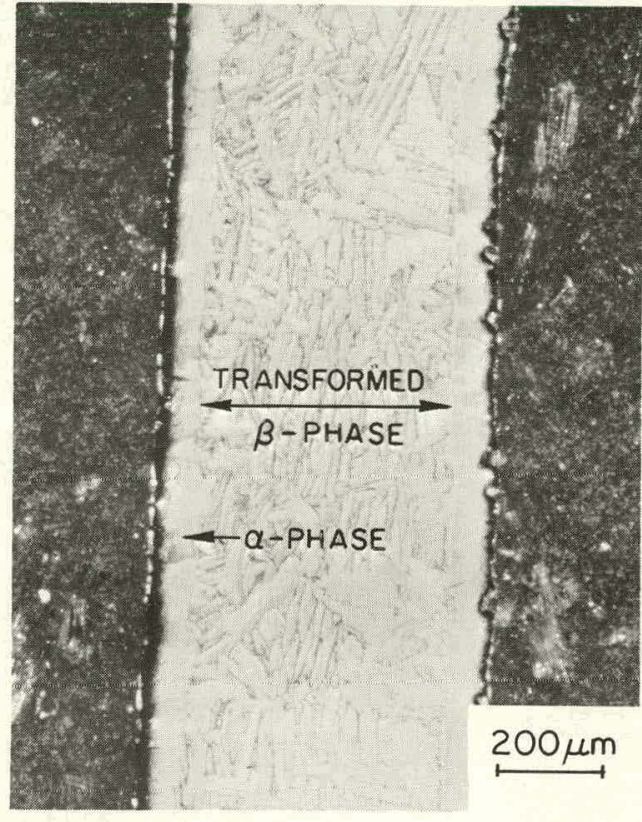

Fig. 110

Microstructure of Zircaloy-4/Oxide Composite Specimen Deformed at $1100^{\circ} \mathrm{C}$ Showing No Cracks in $\alpha$ Layer. ANL Neg.

No. 306-77-88 Rev. 1.

The effect of total oxygen concentration in the composite on the yield stress, ullimate tensile strength, uniform strain, and total strain is presented in Figs. 111-114, respectively. Below $900^{\circ} \mathrm{C}$, the yield stress (Fig. 111) and ultimate tensile strength (Fig. 112) are not sensitive to oxygen concentration. This is the net result of two compensating factors. As the oxygen concentration increases, the oxide-layer thickness also increases. Since the layer cracks during deformation, the load-bearing area decreases. On the other 
hand, the diffusion of oxygen into the base $\alpha$ (or $\alpha+\beta$ ) material increases its strength. Above $950^{\circ} \mathrm{C}$, both the yield stress and ultimate strength increase as the oxygen concentration increases since the $\alpha$ layer does not crack and carries a portion of the load.

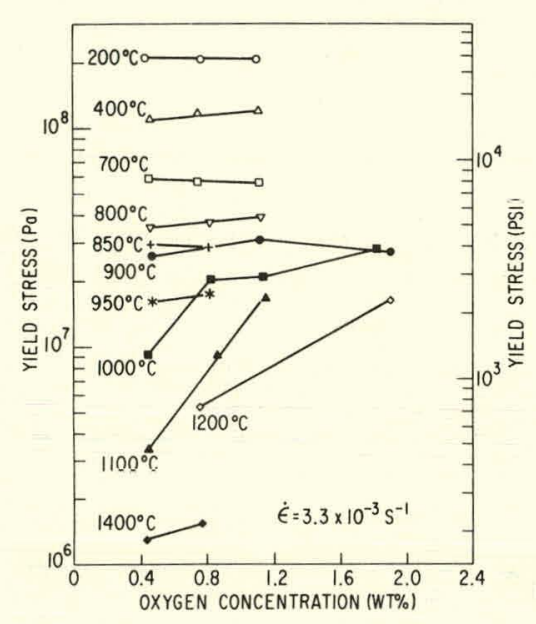

Fig. 111

Oxygen-concentration Dependence of Yield Stress of Zircaloy-4/Oxide Composites at Several Temperatures. ANL Neg. No. 306-77-57 Rev. 1.

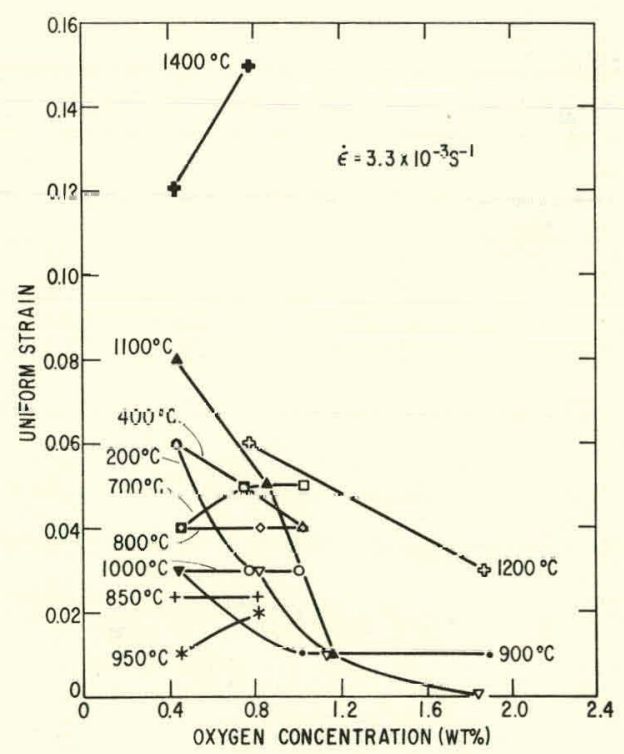

Fig. 113

Effect of Oxygen Concentration on Uniform Strain of Zircaloy-4/Oxide Composites at Several Temperatures. ANL Neg. No. 306-77-52 Rev. 1.

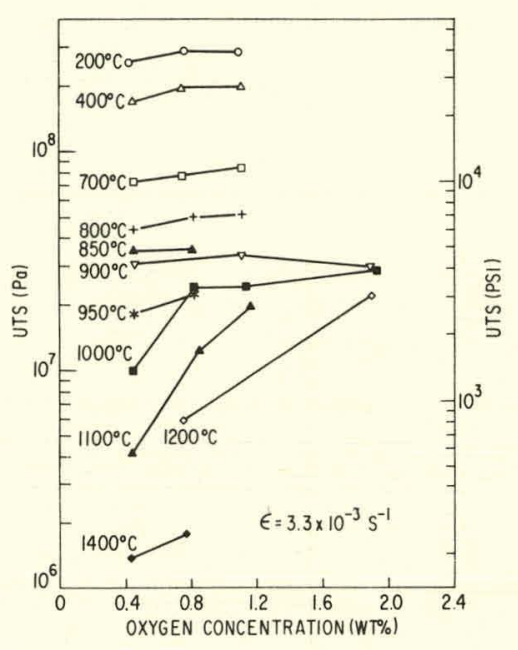

Fig. 112

Ultimate Tensile Strength of Zircaloy-4/Oxide Composites as a Function of Oxygen Concentration at Several Temperatures. ANL Neg. No. 306-77-70 Rev. 1.

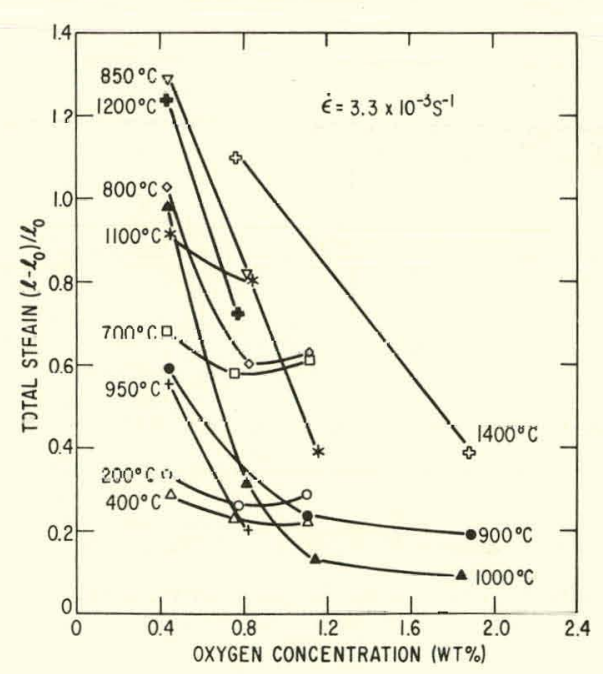

Fig. 114

Variation of Total Strain of Zircaloy-4/ Oxide Composites with Oxygen Concentration at Several Temperatures. ANL Neg. No. 306-77-72 Rev. 1. 
The effect of oxygen on the uniform strain is complicated (Fig. 113), but generally, the uniform strain decreases as the oxygen increases. As shown in Fig. 114, oxygen decreases the total strain of composite material.

The influence of oxygen on the work-hardening rate of composite specimens is shown in Table XXVI and Fig. 115. Generally, an increase in the

TABLE XXVI. Least-squares Work-hardening Constants for Zircaloy-4/Oxide Composite Specimens; $\dot{\varepsilon}=3.3 \times 10^{-3} \mathrm{~s}^{-1}$.

\begin{tabular}{|c|c|c|c|c|c|c|}
\hline $\begin{array}{l}\text { Temp, } \\
{ }^{\circ} \mathrm{C}\end{array}$ & $\begin{array}{c}\text { Oxygen } \\
\text { Concentration, } \\
\text { wt } \%\end{array}$ & $\begin{array}{l}\text { Stage } \\
\text { Number }\end{array}$ & $\begin{array}{l}\text { Strain } \\
\text { Interval }\end{array}$ & $\mathrm{n}$ & $k, P a$ & $\begin{array}{c}\text { Average } \\
\sigma_{0}, \mathrm{~Pa}\end{array}$ \\
\hline 200 & $\begin{array}{l}0.13 \\
0.77 \\
1.10\end{array}$ & $\begin{array}{l}2 \\
3 \\
2 \\
2\end{array}$ & $\begin{array}{c}0.008-0.02 \\
0.025-0.045 \\
0.0004-0.025 \\
0.0004-0.025\end{array}$ & $\begin{array}{r}0.87 \\
-1.40 \\
0.51 \\
0.39\end{array}$ & $\begin{array}{r}1.3 \times 10^{9} \\
-1.3 \times 10^{5} \\
7.3 \times 10^{8} \\
5.7 \times 10^{8}\end{array}$ & $\begin{array}{l}2.0 \times 10^{8} \\
2.8 \times 10^{8} \\
1.8 \times 10^{8} \\
1.6 \times 10^{8}\end{array}$ \\
\hline 400 & $\begin{array}{l}0.75 \\
1.11\end{array}$ & $\begin{array}{l}1 \\
2 \\
3 \\
2 \\
3 \\
2\end{array}$ & $\begin{array}{c}0.0004-0.0016 \\
0.002-0.015 \\
0.02-0.05 \\
0.0004-0.013 \\
0.014-0.04 \\
0.0004-0.011\end{array}$ & $\begin{array}{r}0.12 \\
1.10 \\
-1.40 \\
0.83 \\
-0.88 \\
0.41\end{array}$ & $\begin{array}{r}7.3 \times 10^{7} \\
3.2 \times 10^{9} \\
-1.2 \times 10^{5} \\
2.1 \times 10^{9} \\
-1.4 \times 10^{6} \\
7.4 \times 10^{8}\end{array}$ & $\begin{array}{l}7.5 \times 10^{7} \\
1.1 \times 10^{8} \\
1.9 \times 10^{8} \\
1.0 \times 10^{8} \\
2.3 \times 10^{8} \\
6.5 \times 10^{7}\end{array}$ \\
\hline 700 & $\begin{array}{l}0.45 \\
0.75 \\
1.12\end{array}$ & $\begin{array}{l}2 \\
1 \\
2 \\
1 \\
2\end{array}$ & $\begin{array}{r}0.008-0.04 \\
0.0004-0.008 \\
0.009-0.045 \\
0.0004-0.011 \\
0.012-0.045\end{array}$ & $\begin{array}{r}-0.09 \\
0.55 \\
-0.36 \\
0.28 \\
-0.66\end{array}$ & $\begin{array}{r}-6.2 \times 10^{7} \\
2.8 \times 10^{8} \\
-4.8 \times 10^{6} \\
1.6 \times 10^{8} \\
-1.2 \times 10^{6}\end{array}$ & $\begin{array}{l}1.6 \times 10^{8} \\
4.9 \times 10^{7} \\
9.6 \times 10^{7} \\
2.8 \times 10^{7} \\
9.7 \times 10^{7}\end{array}$ \\
\hline 800 & $\begin{array}{l}0.45 \\
0.82 \\
1.12\end{array}$ & $\begin{array}{l}2 \\
2 \\
1 \\
2\end{array}$ & $\begin{array}{l}0.0004-0.04 \\
0.0004-0.04 \\
0.0004-0.012 \\
0.013-0.035\end{array}$ & $\begin{array}{r}-0.05 \\
-0.09 \\
0.36 \\
-0.96\end{array}$ & $\begin{array}{r}-4.7 \times 10^{7} \\
-3.4 \times 10^{7} \\
9.6 \times 10^{7} \\
-9.6 \times 10^{4}\end{array}$ & $\begin{array}{l}1.0 \times 10^{8} \\
9.7 \times 10^{7} \\
2.9 \times 10^{7} \\
5.5 \times 10^{7}\end{array}$ \\
\hline 850 & $\begin{array}{l}0.45 \\
0.81\end{array}$ & $\begin{array}{l}2 \\
2\end{array}$ & $\begin{array}{l}0.0004-0.025 \\
0.0004-0.02\end{array}$ & $\begin{array}{l}-0.23 \\
-0.12\end{array}$ & $\begin{array}{l}-3.2 \times 10^{6} \\
-1.3 \times 10^{7}\end{array}$ & $\begin{array}{l}4.3 \times 10^{7} \\
5.8 \times 10^{7}\end{array}$ \\
\hline 900 & $\begin{array}{l}0.45 \\
1.11 \\
1.89\end{array}$ & $\begin{array}{l}2 \\
1 \\
2 \\
1 \\
2 \\
3\end{array}$ & $\begin{array}{c}0.0004-0.025 \\
0.0004=0.007 \\
0.008-0.012 \\
0.0004-0.0012 \\
0.0012-0.004 \\
0.004-0.008\end{array}$ & $\begin{array}{r}-0.41 \\
-0.17 \\
-2.50 \\
0.36 \\
-0.67 \\
-2.50\end{array}$ & $\begin{array}{l}-6.6 \times 10^{5} \\
-4.6 \times 10^{6} \\
-3.9 \times 10^{0} \\
1.5 \times 10^{8} \\
-7.7 \times 10^{4} \\
-8.4 \times 10^{-1}\end{array}$ & $\begin{array}{l}3.5 \times 10^{7} \\
4.4 \times 10^{7} \\
3.4 \times 10^{7} \\
1.2 \times 10^{7} \\
3.2 \times 10^{7} \\
3.0 \times 10^{7}\end{array}$ \\
\hline 950 & $\begin{array}{l}0.45 \\
0.82\end{array}$ & $\begin{array}{l}1 \\
2 \\
1 \\
2 \\
3\end{array}$ & $\begin{array}{c}0.0004-0.006 \\
0.00 \%-0.013 \\
0.0004-0.0024 \\
0.0024-0.009 \\
0.009-0.015\end{array}$ & $\begin{array}{r}-0.42 \\
-0.10 \\
0.69 \\
-0.71 \\
-1.90\end{array}$ & $\begin{array}{r}-3.7 \times 10^{5} \\
-2.4 \times 10^{0} \\
5.2 \times 10^{8} \\
-8.4 \times 10^{4} \\
-1.4 \times 10^{2}\end{array}$ & $\begin{array}{l}2.1 \times 10^{7} \\
2.2 \times 10^{1} \\
1.0 \times 10^{7} \\
2.4 \times 10^{7} \\
2.3 \times 10^{7}\end{array}$ \\
\hline 1000 & $\begin{array}{l}0.44 \\
0.82 \\
1.14 \\
1.84\end{array}$ & $\begin{array}{l}2 \\
1 \\
2 \\
2 \\
2\end{array}$ & $\begin{array}{l}0.0004-0.03 \\
0.0004-0.0024 \\
0.0028-0.025 \\
0.0004-0.008 \\
0.0004-0.0036\end{array}$ & $\begin{array}{r}-0.38 \\
0.34 \\
-0.59 \\
-0.25 \\
-0.87\end{array}$ & $\begin{array}{r}-1.5 \times 10^{5} \\
7.1 \times 10^{7} \\
-1.4 \times 10^{5} \\
-2.2 \times 10^{6} \\
-4.7 \times 10^{3}\end{array}$ & $\begin{array}{l}1.1 \times 10^{7} \\
1.1 \times 10^{7} \\
2.6 \times 10^{7} \\
3.1 \times 10^{7} \\
2.9 \times 10^{1}\end{array}$ \\
\hline 1100 & $\begin{array}{l}0.44 \\
0.85 \\
1.16\end{array}$ & $\begin{array}{l}2 \\
1 \\
2 \\
2\end{array}$ & $\begin{array}{c}0.0004-0.07 \\
0.0004-0.004 \\
0.005-0.05 \\
0.0004-0.012\end{array}$ & $\begin{array}{r}0.05 \\
0.90 \\
-0.45 \\
-0.54\end{array}$ & $\begin{array}{r}7.4 \times 10^{6} \\
2.7 \times 10^{0} \\
-3.1 \times 10^{5} \\
-1.3 \times 10^{5}\end{array}$ & $\begin{array}{r}-2.1 \times 10^{6} \\
8.2 \times 10^{6} \\
1.4 \times 10^{7} \\
2.1 \times 10^{7}\end{array}$ \\
\hline 1200 & $\begin{array}{l}0.76 \\
1.88\end{array}$ & $\begin{array}{l}2 \\
1 \\
2\end{array}$ & $\begin{array}{l}0.0004-0.05 \\
0.0004-0.0028 \\
0.0032-0.025\end{array}$ & $\begin{array}{r}-0.20 \\
0.73 \\
-1.10\end{array}$ & $\begin{array}{r}-5.3 \times 10^{5} \\
8.6 \times 10^{8} \\
-4.8 \times 10^{3}\end{array}$ & $\begin{array}{l}7.1 \times 10^{6} \\
6.2 \times 10^{6} \\
2.2 \times 10^{7}\end{array}$ \\
\hline 1400 & $\begin{array}{l}0.43 \\
0.77\end{array}$ & $\begin{array}{l}2 \\
1 \\
2\end{array}$ & $\begin{array}{l}0.0004-0.11 \\
0.0004-0.0028 \\
0.0032-0.11\end{array}$ & $\begin{array}{r}0.89 \\
-0.71 \\
0.50\end{array}$ & $\begin{array}{r}1.8 \times 10^{6} \\
-1.1 \times 10^{3} \\
1.6 \times 10^{6}\end{array}$ & $\begin{array}{l}1.3 \times 10^{6} \\
1.6 \times 10^{6} \\
1.5 \times 10^{6}\end{array}$ \\
\hline
\end{tabular}




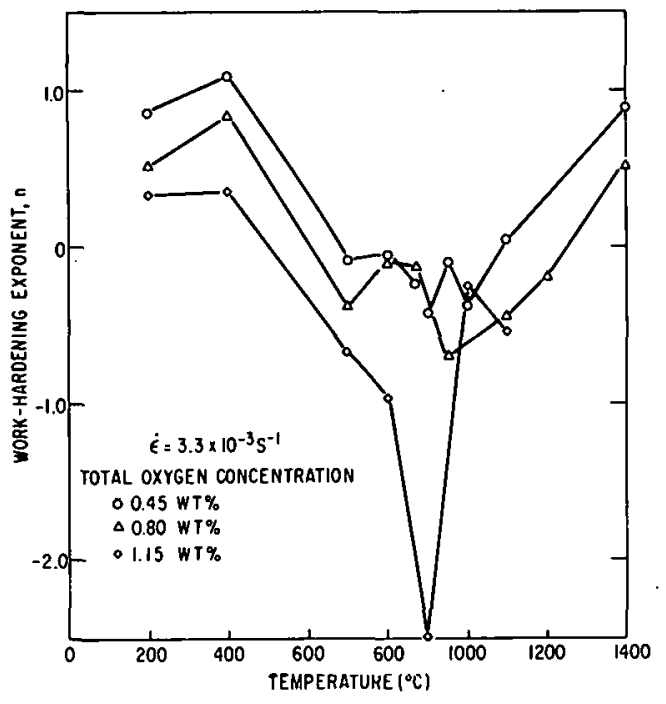

Fig. 115

Temperature Dependence of Work-hardening Exponent of Zircaloy-4/Oxide Composites with Several Oxygen Concentrations. ANL. Neg. No. 306-77-71 Rev. 1. oxygen content dccreases the work-hardening rate of the major deformation stage. This observation is consistent with the data in Fig. 113, which tend to show lower uniform strains for higher oxygen concentrations.

\section{Effect of Cooling Rate on Properties of Composite Specimens}

The furnace used to charge oxygen into Zircaloy specimens does not have a quenching facility. After the power to the furnace is switched off, the cooling rate is slow, i.e., $\sim 0.15^{\circ} \mathrm{C} / \mathrm{s}$. Specimens with oxygen concentrations $>1.75$ wt $\%$ were oxidized in the $\beta$-phase field above $1000^{\circ} \mathrm{C}$, and the slow cooling rate resulted in a codrse lenticuli. struc ture. These composite specimens were placed in another furnace with a quenching facility, heated into the $\beta$-phase field, quenched to room temperature at various cooling rates, and then deformed in the Instron furnace. Because of this heat-treatment cycle, the microstructure and oxygen distribution at the start of deformation are a function of several parameters apart from the cooling rate in the annealing furnace, viz., the cooling rate in the charging furnace, the heating rate in the annealing furnace, and the temperature and time of annealing. Therefore, the data points for the $250^{\circ} \mathrm{C} / \mathrm{s}$ cooling rate in Figs. $116-119$ refer to a complex microstructure not representative of the fast cooling rate alune.

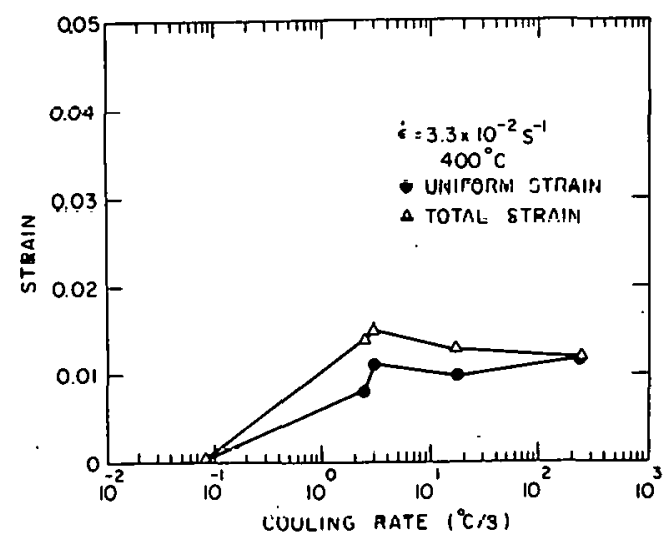

Fig. 116. Uniform and Total Strain of Zircaloy-4/ Oxide Composites with $4.0 \mathrm{wt} \%$ Oxygen as a Function of Cooling Rate. Neg. No. MSD-63836.

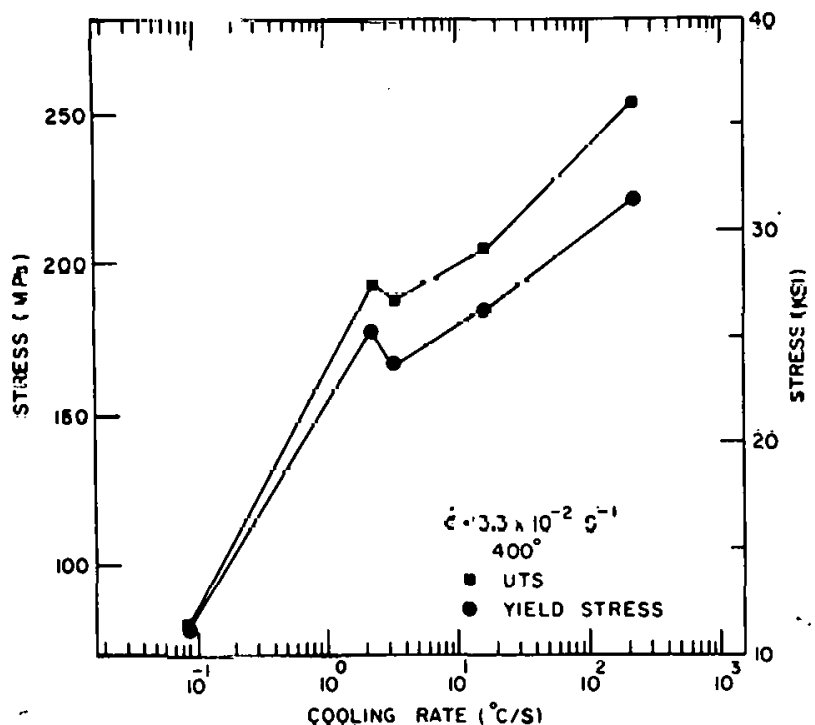

Fig. 117. Ultimate Tensile Strength and Yield Stress as a Function of Cooling Rate for Zircaloy-4/ Oxide Composites with $4.0 \mathrm{wt} \%$ Oxygen. Neg. No. MSD-63837. 


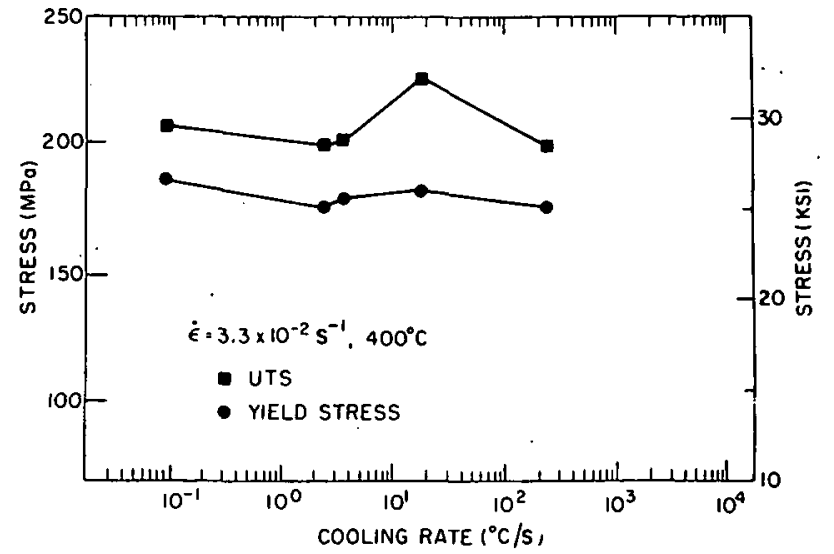

Fig. 118. Effect of Cooling Rate on Yield Stress and Ultimate Tensile Strength of Composite Zircaloy-4 Specimens with 4.4 wt \% Oxygen. Ne.g. No. MSD-63839.

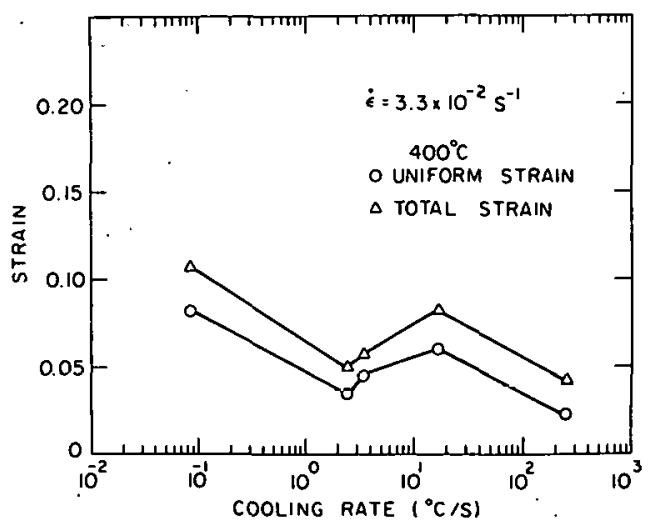

Fig. 119. Influence of Cooling Rate on Uniform and Total Strain of Composite Zircaloy 4 Specimens with 4.4 wt \% Oxygen. Neg. No. MSD-63840.

The strength and ductility of the material with 4.0 wt $\%$ oxygen, in Figs. 116 and 117, respectively, are quite low, particularly at the $0.09^{\circ} \mathrm{C} / \mathrm{s}$ cooling rate. Oxygen penetration into the material at the $1100^{\circ} \mathrm{C}$ charging temperature and the significant amount of oxygen redistribution that occurred during slow cooling through the phase transformation cause a degradation in the properties. As the cooling rate increases, both the strength and ductility increase; however, the total strain is quite small $(<0.02)$ at all cooling rates.

The yield stress and ultimate tensile strength of the specimens with 4.4 wt \% oxygen, in Fig. 118, are not strongly dependent on the cooling rate. The ductility data in Fig. 119 show a peak at a cooling rate of $\sim 17^{\circ} \mathrm{C} / \mathrm{s}$. Despite the somewhat higher total oxygen concentration (4.4 wt \%) in these specimens, the ductility is significantly higher than for the composite material with 4.0 wt $\%$ oxygen. This observation implies that the time-temperature history is an important variable with regard to the mechanical properties. For specimens with $4.4 \mathrm{wt} \%$ oxygen, the oxidation temperature was $1000^{\circ} \mathrm{C}$. Consequently, oxygen diffusion into the central $\beta$ (or two-phase) region occurred to a lesser extent than in the material with 4.0 wt $\%$ oxygen, for which the oxidation temperature was $1100^{\circ} \mathrm{C}$. 


\section{ACTIVATION ENERGY FOR HIGH-TEMPERATURE DEFORMATION OF ZIRCALOY}

If the deformation of $\mathrm{Zircaloy}$ is assumed to be thermally activated, the strain rate $\dot{\epsilon}$ during steady-state deformation can be expressed in terms of a constant $A$, shear modulus $G$, Boltzmann constant $k$, Burgers Vector $b$, stress $\sigma$, grain size $D$, absolute temperature $T$, grain-size exponent $p$, stress exponent $\mathrm{n}$ (i.e., $\mathrm{n}=1 / \mathrm{m}$ in Eq. 3), activation energy for deformation $Q$, and the gas constant $R$; i.e.,

$$
\dot{\varepsilon}=\frac{A G}{k T}\left(\frac{b}{D}\right)^{P}\left(\frac{\sigma}{G}\right)^{n} \exp \left(-\frac{Q}{R T}\right) .
$$

A plot of $\log \dot{\mathrm{kT}} / \mathrm{G}$ versus reciprocal temperature at a constant value of $u / C$ and grain size can be used to evaluate $Q$. As pointed out by Gifkins, ${ }^{38}$. two precautions should be taken to obtain a meaningfil value for $Q$; $i . D_{\text {: }}$, the temperature range should be selected so that the stress exponent (and hence, the strain-rate sensitivity) is approximately constant and no change in the deformation mechanism occurs for the particular value of $\sigma / G$.

More complete results for the strain-rate dependence of the $0.2 \%$ yield stress of 5- and $11-\mu \mathrm{m}$ grain-size $\mathrm{Zircaloy}-4$ at several temperatures between 700 and $1000^{\circ} \mathrm{C}$ are shown in Figs. 120 and 121 , respectively. These data suggest a tendency toward an S-shape sigmoidal curve, as observed in other superplastic materials, although a constant threshold stress ${ }^{39}$ at low strain rates is not evident. The comparatively large slope of the curves at temperatures betwecn 850 and $950^{\circ} \mathrm{C}$ and stress levels $\leqslant 6 \mathrm{MPa}$ is indicative of a high value of $\mathrm{m}$. (stage-II deformation), whereas at higher stress levels the $m$-value is lower (stage-III deformation).

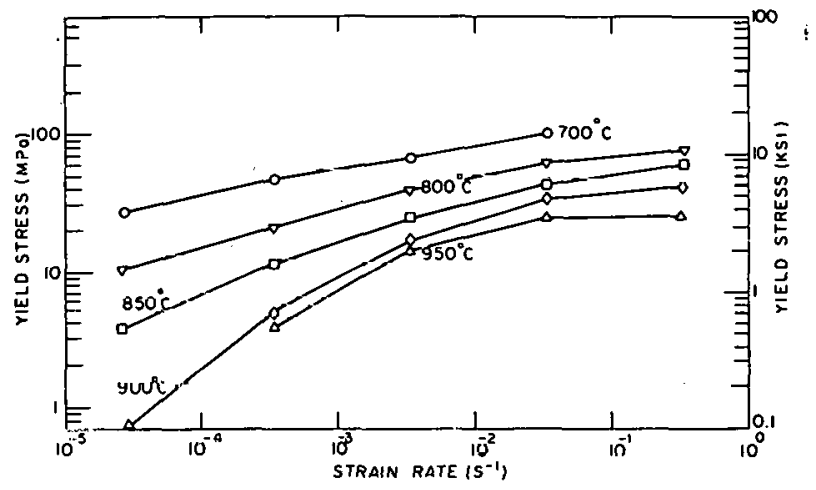

Fig. 120. Strain-rate Dependence of $0.2 \%$ Yield Stress of $5-\mu \mathrm{m}$ Grain-size Zircaloy-4 at Scveral Temperatures between 700 and $950^{\circ} \mathrm{C}$. ANL Neg. No. 306-76-256 Rev. 1.

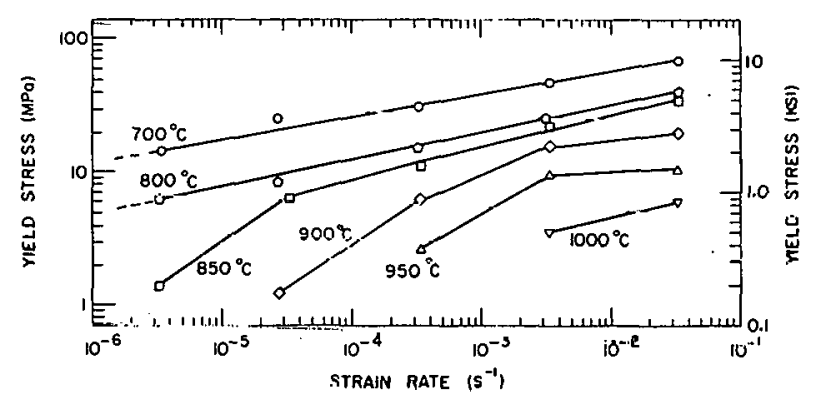

Fig. 121. Strain-rate Dependence of $0.2 \%$ Yield Stress of $11-\mu \mathrm{m}$ Grain-size Zircaloy-4 at Several Temperatures between 700 and $1000^{\wedge} \mathrm{C}$. ANL Neg. No. 306-76-242 Rev. 1. 
The deformation stages II and III refer to the intermediate and high strain-rate ranges, respectively, on a plot of the flow stress $\sigma$ versus the strain rate $\dot{\epsilon}$, e.g., Figs. 120 and 121 , in contrast to the work-hardening stages 1, 2, and 3, obtained from plots of $d \sigma / d \epsilon$ versus strain $\varepsilon$. As the temperature increases, the transition from stage-II to -III behavior occurs at higher strain rates.

The temperature dependence for the stage-III deformation process for the 5- and 11- $\mu \mathrm{m}$ grain-size material is shown in Figs. 122 and 123, respectively, in which the strain rate and compensated strain rate, at constant stress $\sigma$ or $\sigma / G$, are plotted as a function of reciprocal temperature. The activation energies for stage-III deformation, defined by either

$$
Q=-\left.R \frac{d \ln (\dot{\epsilon})}{d(1 / T)}\right|_{\sigma}
$$

or

$$
Q=-\left.R \frac{d \ln (\dot{\varepsilon} k T / G)}{d(1 / T)}\right|_{\sigma / G}
$$

were computed from the slopes of the respective curves.

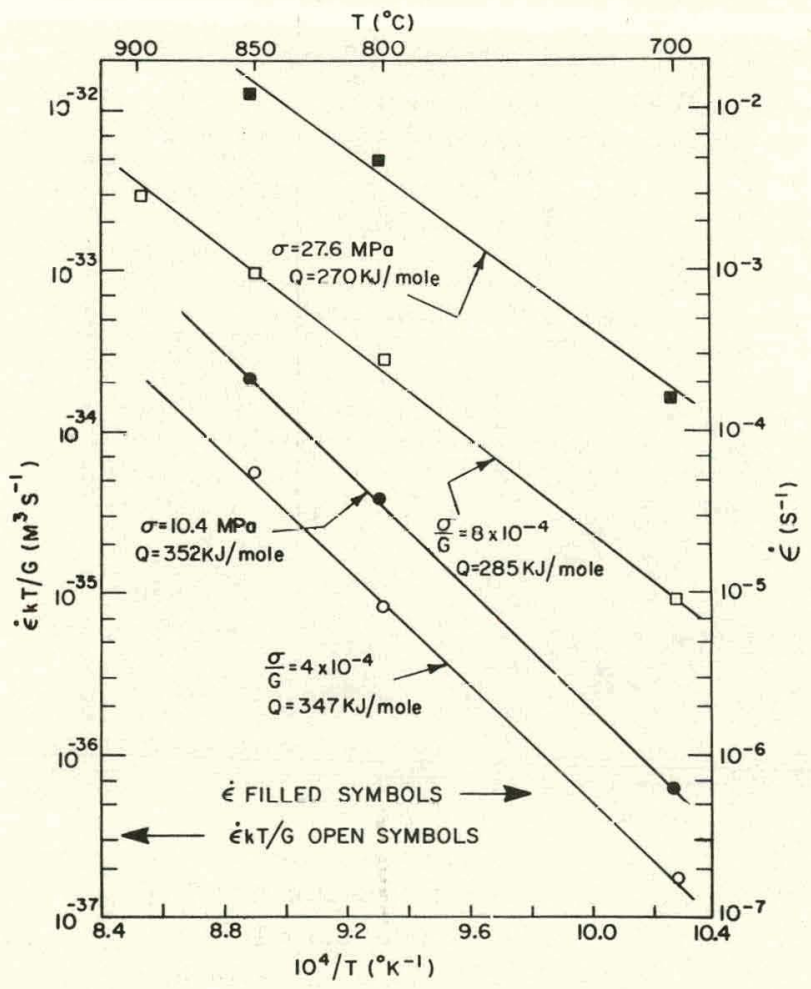

Fig. 122. Temperature Dependence of Strain Rate for Stage-III Deformation of $5-\mu \mathrm{m}$ Grain-size Zircaloy-4. ANL Neg. No. 306-76-250 Rev. 2.

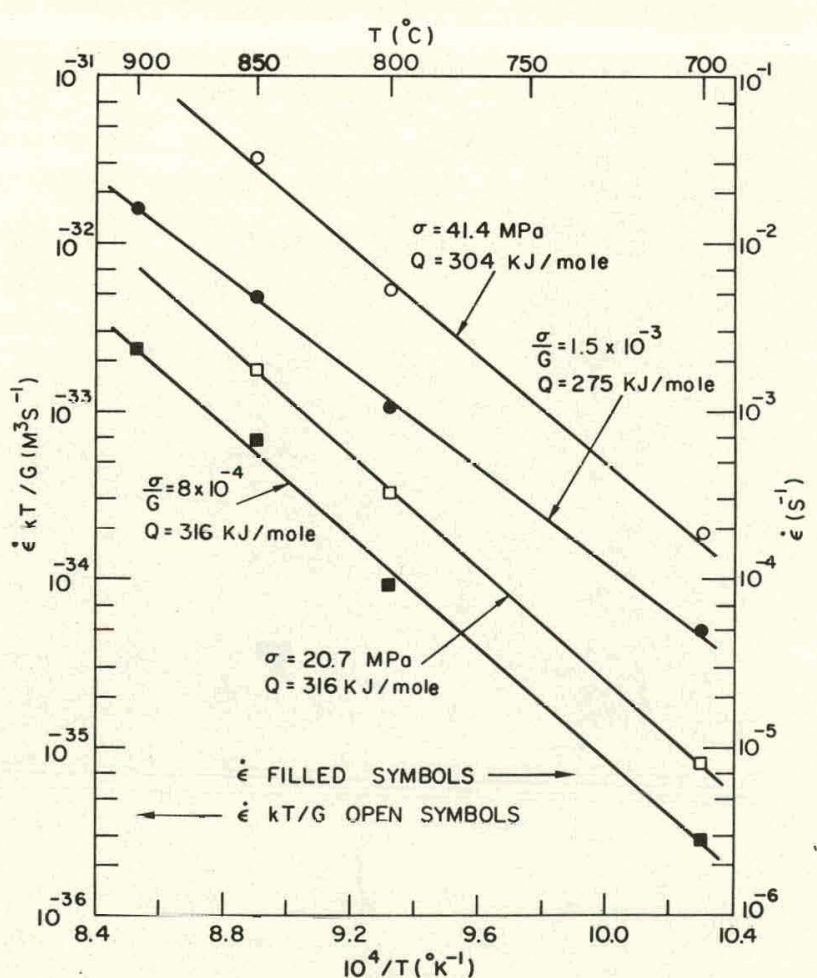

Fig. 123. Temperature Dependence of Strain Rate for Stage-III Deformation of $11-\mu \mathrm{m}$ Grain-size Zircaloy-4. Neg. No. MSD-63431. 
The shear modulus of zirconium (calculated from the relationship given by Hearmon ${ }^{40}$ and the elastic-constant data of Fisher and Renken ${ }^{41}$ ) was used to obtain the compensated strain-rate curves. The activation energies in the range of $270-352 \mathrm{~kJ} / \mathrm{moleobtained} \mathrm{from} \mathrm{Eqs.} 5$ and 6 are stress dependent; i.e., the $Q$ values in Figs. 122 and 123 decrease with an increase in stress. This behavior is consistent with the increase in the $\mathrm{m}$ value with temperature over the 700 to $900^{\circ} \mathrm{C}$ range (Figs. 39 and 60 for the $5-$ and $11-\mu \mathrm{m}$ grain-size material, respectively). The values of the activation energy are in good agreement with those obtained by Kearns et al. ${ }^{42}$ for the deformation of Zircaloy-hydrogen alloys $(304-365 \mathrm{~kJ} / \mathrm{mole})$ and in reasonable agreement with the activation energies for self-diffusion in $\alpha$-Zircaloy $\left(218,{ }^{43} 276,{ }^{44}\right.$ and $\left.282^{45} \mathrm{~kJ} / \mathrm{mole}\right)$.

\section{SUPERPT،ASTICITY OF ZIRCALOY}

The Zircaloy-2 and -4 tensile data show that both exhibit superplastic deformation between 800 and $1000^{\circ} \mathrm{C}$. Maximum superplasticity is observed between 850 and $900^{\circ} \mathrm{C}$. The exact temperature of maximum elongation is a function of strain rate (Figs. 21 and 38). At this temperature, Zircaloy is in the two-phase region with a high volume fraction of $\alpha$ phase. The small amount of $\beta$, located at the $\alpha$-grain boundaries, is similar to a grain-boundary film (Fig. 124) and restricts the growth of the $\alpha$ grains.

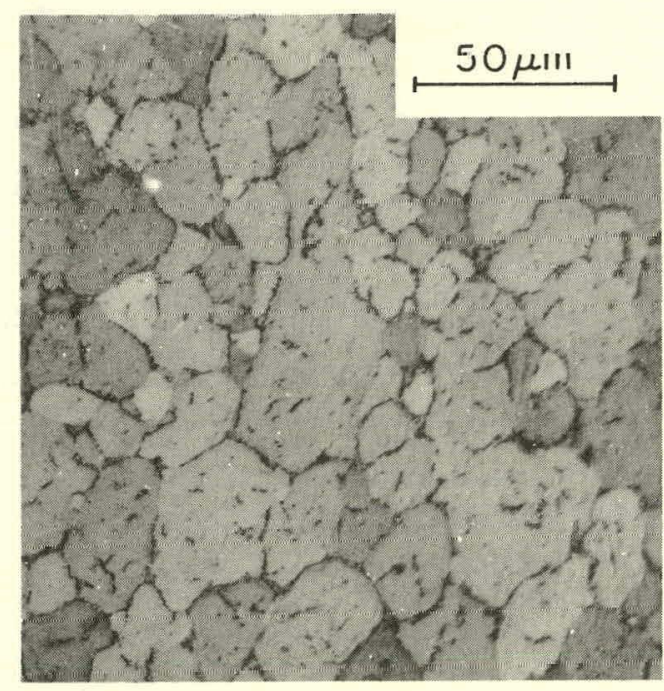

(a)

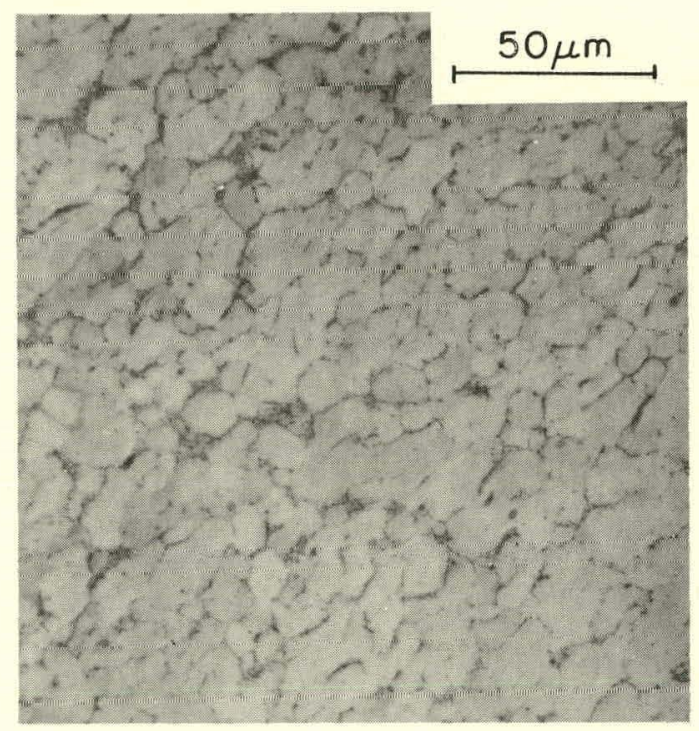

(b)

Fig. 124. Microstructure near (a) Shoulder Region $(\varepsilon \simeq 0)$ and (b) Fracture Region $(\varepsilon \simeq 2.1)$ of a Zircaloy-4 Specimen Deformed at $850^{\circ} \mathrm{C}$ at a Strain Rate of $3.3 \times 10^{-3} \mathrm{~s}^{-1}$. Etched and anodized. Polarized light. Neg. Nos. MSD-61479 and -61455 . 
The microstructures of the specimens deformed at $800-850^{\circ} \mathrm{C}$ were dependent on strain rate. At $850^{\circ} \mathrm{C}$ and $\dot{\varepsilon}=3.3 \times 10^{-3} \mathrm{~s}^{-1}$, the deformed region exhibited completely equiaxed $\alpha$ grains surrounded by a $\beta$ film at the grain boundaries (Fig. 124). Moreover, the deformed region has a smaller grain size $(\sim 7 \mu \mathrm{m})$ than the starting material $(\sim 11 \mu \mathrm{m})$. Because of the fine equiaxed structure, substantial superplasticity occurred at this strain rate.

At $850^{\circ} \mathrm{C}$ and a strain rate of $3.3 \times 10^{-1} \mathrm{~s}^{-1}$, the deformed region of the specimen had elongated grains (see Fig. 125), grain-boundary sliding was less pronounced, and the ductility was low. At low strain rates and in fine-grainsize material, where superplastic phenomena are significant, equiaxed grain structure is maintained after extensive deformation (Fig. 126).

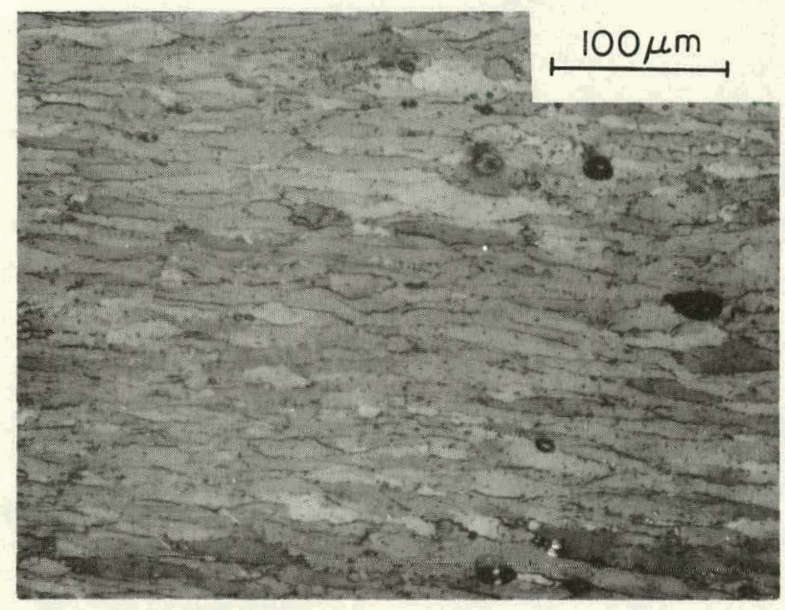

Fig. 125. Microstructure of an $11-\mu \mathrm{m}$ Grainsize Specimen Deformed to $0.7 \mathrm{Strain}$ at a Etrain Rate of $3 \cap \times 10^{-1} \mathrm{~s}^{-1}$ at $850^{\circ} \mathrm{C}$. Neg. No. MSD-63405.

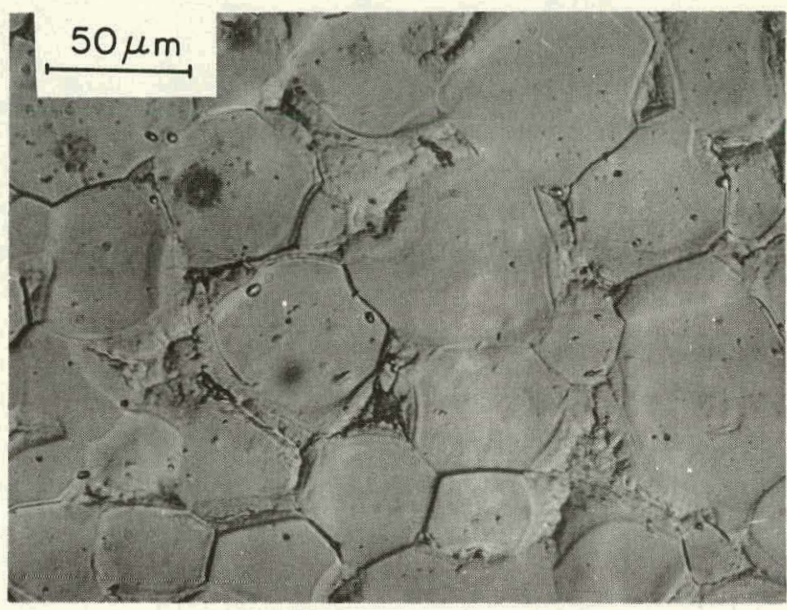

Fig. 126. Microstructure of a $5-\mu \mathrm{m}$ Grain-size Specimen Deformed to $\sim 1.5$ Strain at a Strain Rate of $6.0 \times 10^{-6} \mathrm{~s}^{-1}$ at $850^{\circ} \mathrm{C}$. Neg. No. IVISD-60403.

For the as-received Zircaloy containing $0.11 \mathrm{wt} \%$ oxygen at $1000^{\circ} \mathrm{C}$, the structure is single-phase $\beta$. Because of the high temperature, the lowoxygen-concentration $\beta$ phase is superplastic. This elongation peak was not detected by German workers ${ }^{34}$ because the high-temperature testing in air resulted in an increase in the oxygen concentration of the material.

Scanning-electron-microscopy (SEM) fractographs of specimens fractured at temperatures corresponding to the maxima and minimum in the curves of total elongation versus temperature in Fig. 21 provide additional insight into the deformation behavior. The SEM fractograph (Fig. 127) of a specimen fractured at $800^{\circ} \mathrm{C}$ and a strain rate of $3.3 \times 10^{-2} \mathrm{~s}^{-1}$ exhibits tensile dimples characteristic of a ductile failure. A large ductility is evident from the depth of the dimples and the sharpness of the dimple ridges. 


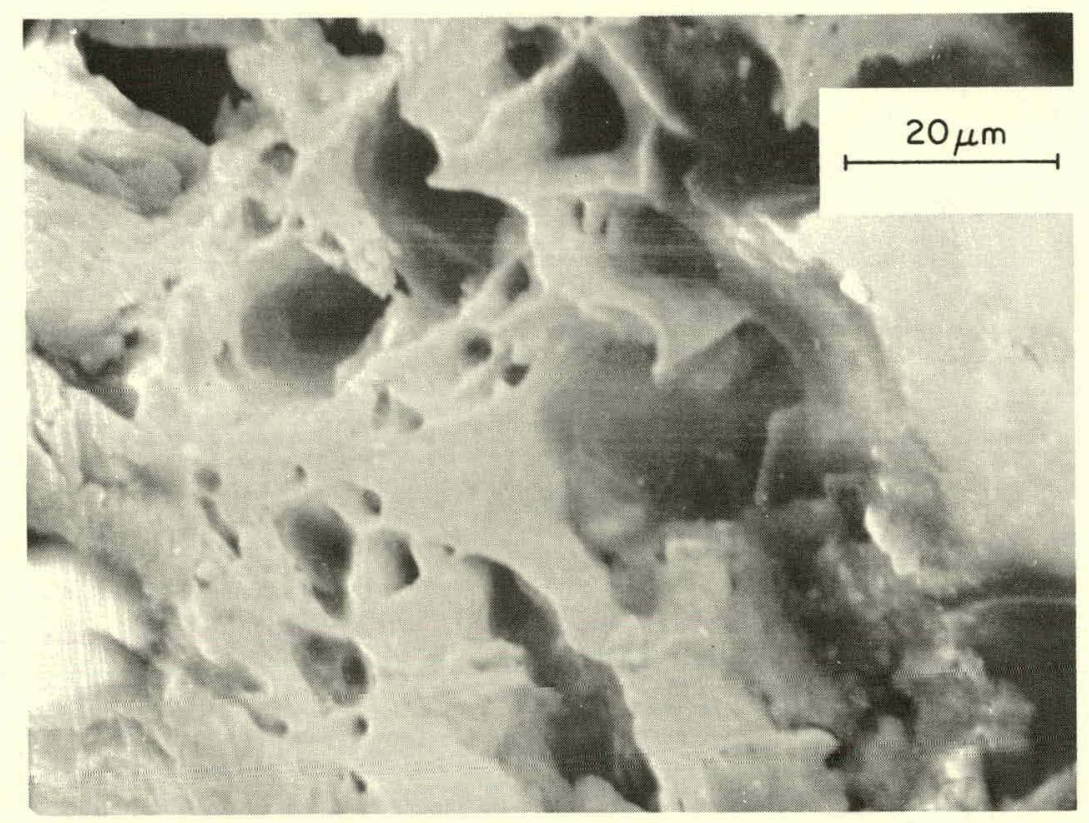

Fig. 127. SEM Fractograph of a Zircaloy-4 Specimen Fractured at $800^{\circ} \mathrm{C}$; $\dot{\varepsilon}=3.3 \times 10^{-2} \mathrm{~s}^{-1}$. ANL Neg. No. 306-75-123 Rev. 1 .

Figure 128 is a fractograph of a specimen fractured at $950^{\circ} \mathrm{C}$ and a strain rate of $3.3 \times 10^{-3} \mathrm{~s}^{-1}$. This temperature corresponds to the minimum in the curve of total elongation versus temperature in Fig. 21. The photograph was taken viewing down on the fracture edge, which is the line joining the two arrows. The fractograph shows an $\alpha$ particle on the fracture edge that failed in a brittle manner (evidenced by the characteristic river pattern inside the black region), whereas the surrounding $\beta$ phase failed in a ductile manner

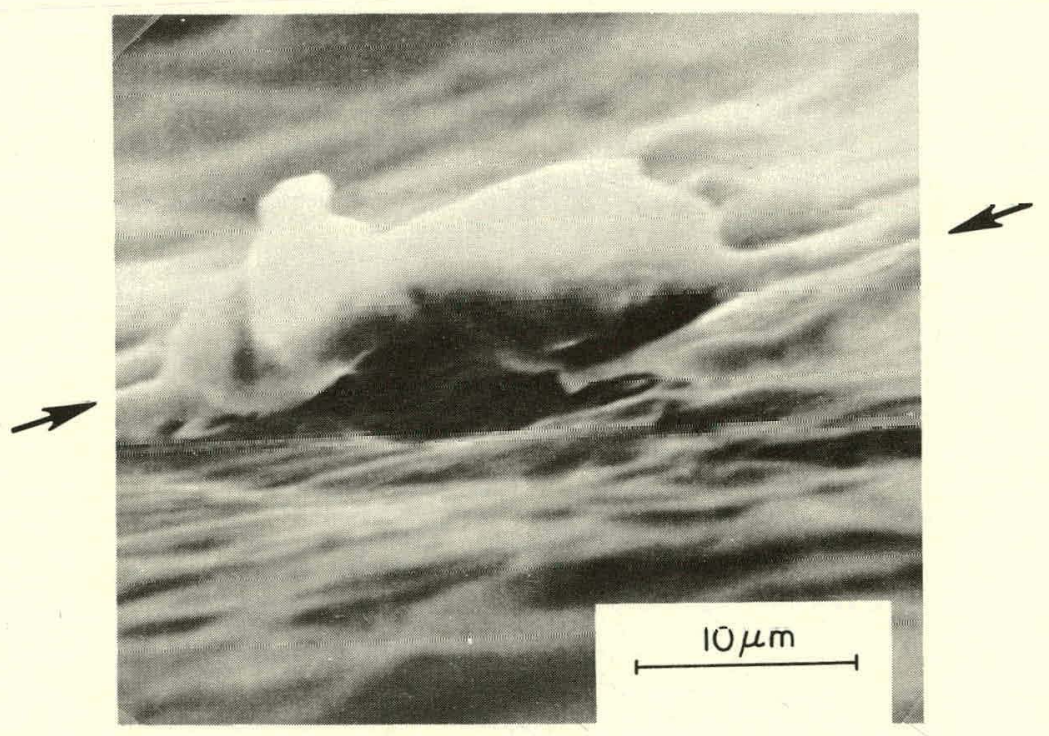

Fig. 128. SEM Fractograph of a Zircaloy-4 Specimen Fracturcd at $950^{\circ} \mathrm{C} ; \dot{\boldsymbol{\epsilon}}=3.3 \times 10^{-3} \mathrm{~s}^{-1}$. Fracture edge is the line joining the arrows. ANL Neg. No. 306-75-127 Rev. 1. 
(manifested by the white tear ridge). Such particles were observed all along the fracture edge. From phase-diagram considerations, the structure of the material at this temperature would consist of a higher fraction of $\beta$ phase with a low oxygen content and a smaller fraction of $\alpha$ phase with relatively high oxygen concentration. This structure would be equivalent to a distribution of hard particles $(\alpha)$ in a soft matrix $(\beta)$. When this type of structure is strained, the hard particles would be expected to fail in a brittle manner, which initiates total fracture.

In a high-temperature tensile test, unusually large elongations can occur as a result of the strain-rate dependence of either the flow stress or the work-hardening rate. The former is attributed to superplasticity; the latter is attributed to dynamic strain aging. ${ }^{46}$ Superplasticity is generally associated with a large value of the strain-rate-sensitivity parameter $m(m \geqslant 0.3)$.

There are two types of superplasticity: structural and environmental. Structural superplasticity is observed in single-phase or two-phase fine-grain material (grain size $\leqslant 10 \mu \mathrm{m}$ ) deformed at temperatures above $\sim 0.5 \mathrm{Tm}$. The presence of the second phase is not essential, but it can stabilize the grain size of the material. Environmental superplasticity results from anisotropic dimensional changes that occur when a material is thermally cycled at a transformation temperature under a small load. Evidence for structural superplasticity in $\mathrm{Zircaloy},{ }^{47} \mathrm{Zircaloy}-4 /$ hydrogen alloys,${ }^{42}$ and zirconiumniobium alloy, ${ }^{48}$ and environmental superplasticity in zirconium ${ }^{49}$ has been reported. Results in this report include a detailed investigation of micrograin superplasticity in Zircaloy.

We conducted a scoping test to check the extent of environmental superplasticity in Zircaloy. Since Zircaloy undergoes an $\alpha \rightarrow \beta$ phasetransformation above $\sim 805^{\circ} \mathrm{C}$, transformation-induced superplastic deformation may be obtained by thermal-cycling Zircaloy under a small load between 800 and $1000^{\circ} \mathrm{C}$. Such an experiment was conducted with a $0.11-\mathrm{MPa}$ (16-psi) stress. After 50 cycles, only $14 \%$ strain was observed when compared with noncycled material. Since the high-temperature $\beta$ phase always transforms to nonequiaxed $\alpha^{\prime}$ grains when Zircaloy is cooled to lower temperatures, the nonequiaxed grains may be responsible for the low transformation plasticity in Zircaloy. The redistribution of alloying elements during phase transformation will also influence the environmental superplasticity of Zircaloy.

Data in this report clearly demonstrate that micrograin superplasticity is important in Zircaloy (a) at low strain rates $\left(<10^{-4} \mathrm{~s}^{-1}\right)$ and (b) for temperatures and oxygen concentrations that resull in a two-phase structure consisting of $\sim 10 \%$ volume fraction of $\beta$ phase distributed in the form of a fine-grainboundary film between $\alpha$ grains. The elongation peaks are typical of a superplastic material in which most of the total strain results from the necking strain that follows uniform elongation. 
The equiaxed grain structure observed after extensive superplastic deformation can be a result of either (1) dynamic recrystallization, in which new equiaxed grains are generated continuously during deformation, or (2) deformation, mainly by grain-boundary sliding (with some accommodation mechanism), so that grains do not elongate during deformation. As we will discuss shortly, the second possibility seems more likely.

A decrease in the strain rate increases the extent of superplasticity at $\sim 850^{\circ} \mathrm{C}$ (Figs. 21 and 38), which indicates the importance of grain-boundary

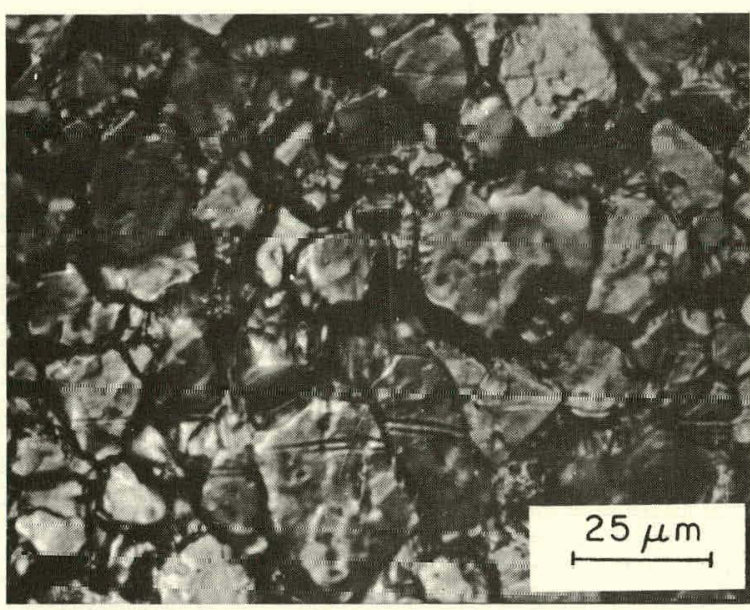

Fig. 129

Micrograph of Scratched Surface of a $5-\mu \mathrm{m}$ Grain-size Zircaloy-4 Specimen Deformed at a Strain Rate of $3.3 \times 10^{-4} \mathrm{~s}^{-1}$ at $900^{\circ} \mathrm{C}$ Showing Offsets of Inscribed Scratches at Grain Boundaries. Neg. No. MSD-63402: sliding. Direct evidence for grainboundary sliding is presented in Fig. 129, a mic rograph of the surface of a $5-\mu \mathrm{m}$ spccimen deformed at a strain rate of $3 \times 10^{-4} \mathrm{~s}^{-1}$ at $900^{\circ} \mathrm{C}$. Before the test, several light scratches were inscribed on the gauge-1ength region, porpendicular to the tensile axis. Scratch-direction offsets at the grain boundaries after deformation imply grain-hnundary sliding. With a decrease in strain rate (Figs. 21 and 38 ), the elongation peak shifts to higher tempcrature, i.e., further inside the two-phase region. This otservaliuis suggests that the grain-boundary-sliding contribution to superplasticity probably occurs at the $\alpha-\beta$ interface.

A change in the deformation mechanism is apparent from the dependence of the yield stress on grain size

at the different strain rates in Fig. 47. As the strain rate decreases, a transition from normal to superplastic deformation occurs. The results in Fig. 17 imply that at large strain rates $\left(>10^{-4} \mathrm{~s}^{-1}\right)$ dislocation creep is predominant, whereas at low strain rates $\left(<10^{-4} \mathrm{~s}^{-1}\right)$ grain-boundary sliding becomes important during the deformation of $\mathrm{Zircaloy}$ at $850^{\circ} \mathrm{C}$.

To maintain coherency of the material during grain-boundary sliding, some accommodation is necessary at the triple points of adjacent grains. This accommodation can be achieved ${ }^{50}$ by (1) diffusional flow, (2) dislucaliun slip, (3) grain-boundary migration, or (4) recrystallization. Dynamic recrystallization is expected to be more difficult in a two-phase structure than in a singlephase alloy, since recrystallization involves a partitioning of alloying elements. Moreover, if dynamic recrystallization occurs simultaneously during deformation, serrations are normally observed on the load-elongation curve. 
Since no serrations were observed on the Zircaloy load-elongation curves at $850^{\circ} \mathrm{C}$ and $\mathrm{Zircaloy}$ has a two-phase structure at this temperature, dynamic recrystallization is not expected to be the accommodation mechanism during superplastic deformation. The present evidence suggests that the three remaining accommodation processes operate to various degrees at different strain-rate and flow-stress levels during the superplastic deformation of $Z$ ircaloy. The high value of $\mathrm{m}$ at low strain rates is indicative of diffusional flow. The grain-boundary traces at the triple points in the microstructure of Fig. 126 provide evidence for grain-boundary migration. The low value of $\mathrm{m}$ and elongated grains at high-strain rates are indicative of dislocation creep. The small extent of grain-size refinement after deformation at intermediate strain rates also suggests grain-boundary migration.

Significant differences observed in the microstructures of specimens deformed at high and low strain rates at $850^{\circ} \mathrm{C}$ are related to the deformation mechanisms. At fast strain rates $\left(10^{-1} \mathrm{~s}^{-1}\right)$, in which transgranular deformation due to dislocation motion was important and the ductility was low, an elongated grain structure with minimal grain growth was typically observed, e.g., Fig. 125. At slow strain rates $\left(10^{-6} \mathrm{~s}^{-1}\right)$, where intergranular deformation due to grain-boundary sliding was dominant and the ductility was higher, the deformed region of the specimen exhibited equiaxed grains, in which considerable grain growth is evident (Fig. 126).

The influence of strain rate and grain size on the work-hardening characteristics of $\mathrm{Zircaloy}$ at $850^{\circ} \mathrm{C}$ is presented in Tables XXVII-XXIX and Fig. 130. The figure shows that superplasticity is associated with a minimum value of the work-hardening exponent that occurs at intermediate strain rates $\left(10^{-4}-10^{-3} \mathrm{~s}^{-1}\right)$. At higher strain rates $\left(>10^{-2} \mathrm{~s}^{-1}\right)$, the work-hardening exponent is higher due to intergranular deformation, and superplasticity is less significant. At lower strain rates $\left(<10^{-4} \mathrm{~s}^{-1}\right)$, although grain-boundary sliding is significant, extensive grain growth due to substantial test times gives rise to hardening, and superplasticity is less significant. An optimum combination of grain-boundary sliding and a stable equiaxed grain structure is obtained at intermediate strain rates, where superplasticity is predominant:

TABLE XXVII. Least-squares Work-hardening Constants for 5- $\mu \mathrm{m}$ Grain-size Zircaloy-4 Specimens Deformed at $850^{\circ} \mathrm{C}$ and Various Strain Rates

\begin{tabular}{|c|c|c|c|c|c|}
\hline $\begin{array}{l}\text { Strain } \\
\text { Rate } \\
\dot{\epsilon}, s^{-i}\end{array}$ & $\begin{array}{c}\text { Stage } \\
\text { Number }\end{array}$ & $\begin{array}{l}\text { Strain } \\
\text { Interval }\end{array}$ & n & $\mathrm{k}, \mathrm{Pa}$ & $\begin{array}{c}\text { Average } \\
\sigma_{0}, \mathrm{~Pa}\end{array}$ \\
\hline $3.3 \times 10^{-2}$ & 2 & $0.0004-0.005$ & .0 .57 & $.9 .4 \times 10^{4}$ & $4.5 \times 10^{7}$ \\
\hline $3.3 \times 10^{-3}$ & 2 & $0.0004,0.0024$ & -0.96 & $-2.0 \times 10^{3}$ & $2.6 \times 10^{7}$ \\
\hline $3.3 \times 10^{-4}$ & $\begin{array}{l}1 \\
2\end{array}$ & $\begin{array}{l}0.0004-0.002 \\
0.0024-0.013\end{array}$ & $\begin{array}{r}0.55 \\
-1.10\end{array}$ & $\begin{array}{r}1.1 \times 10^{8} \\
-1.5 \times 10^{3}\end{array}$ & $\begin{array}{l}7.5 \times 10^{6} \\
1.3 \times 10^{7}\end{array}$ \\
\hline $3.3 \times 10^{-5}$ & $\begin{array}{l}1 \\
2\end{array}$ & $\begin{array}{c}0.0004-0.006 \\
0.007-0.09\end{array}$ & $\begin{array}{r}0.90 \\
-0.26\end{array}$ & $\begin{array}{r}1: 1 \times 10^{8} \\
-6.1 \times 10^{5}\end{array}$ & $\begin{array}{l}3.3 \times 10^{6} \\
6.7 \times 10^{6}\end{array}$ \\
\hline $3.3 \times 10^{-6}$ & $\begin{array}{l}1 \\
2\end{array}$ & $\begin{array}{l}0.0004-0.0032 \\
0.0036-0.13\end{array}$ & $\begin{array}{l}0.82 \\
0.32\end{array}$ & $\begin{array}{l}1.2 \times 10^{8} \\
2.0 \times 10^{2}\end{array}$ & $\begin{array}{l}1.0 \times 10^{6} \\
1.4 \times 10^{7}\end{array}$ \\
\hline $3.3 \times 10^{-6}$ & $\begin{array}{l}1 \\
2\end{array}$ & $\begin{array}{c}0.0004-0.014 \\
0.015-0.37\end{array}$ & $\begin{array}{l}0.05 \\
0.99\end{array}$ & $\begin{array}{l}6.9 \times 10^{6} \\
7.8 \times 10^{6}\end{array}$ & $\begin{array}{r}-2.4 \times 10^{6} \\
3.1 \times 10^{6}\end{array}$ \\
\hline
\end{tabular}


TABLE XXVIII. Least-squares Work-hardening Constants for $11-\mu \mathrm{m}$ Grain-size Zircaloy -4 Specimens Deformed at $850^{\circ} \mathrm{C}$ and Various Strain Rates

\begin{tabular}{|c|c|c|c|c|c|}
\hline $\begin{array}{l}\text { Strain } \\
\text { Rate, } \\
\dot{\epsilon}, s^{-1}\end{array}$ & $\begin{array}{c}\text { Stage } \\
\text { Number }\end{array}$ & $\begin{array}{c}\text { Strain } \\
\text { Interval }\end{array}$ & $\mathrm{n}$ & $\mathrm{k}, \mathrm{Pa}$ & $\begin{array}{c}\text { Average } \\
\sigma_{0}, \mathrm{~Pa}\end{array}$ \\
\hline $3.3 \times 10^{-2}$ & $\begin{array}{l}2 \\
3\end{array}$ & $\begin{array}{r}0.0004-0.009 \\
0.01-0.035\end{array}$ & $\begin{array}{r}0.85 \\
-0.83\end{array}$ & $\begin{array}{r}4.7 \times 10^{8} \\
-1.3 \times 10^{5}\end{array}$ & $\begin{array}{l}2.9 \times 10^{7} \\
4.4 \times 10^{7}\end{array}$ \\
\hline $3.3 \times 10^{-3}$ & $\begin{array}{l}1 \\
2\end{array}$ & $\begin{array}{l}0.0004-0.0012 \\
0.0016-0.03\end{array}$ & $\begin{array}{r}0.70 \\
-0.27\end{array}$ & $\begin{array}{r}3.5 \times 10^{8} \\
-1.2 \times 10^{6}\end{array}$ & $\begin{array}{l}1.9 \times 10^{7} \\
2.9 \times 10^{7}\end{array}$ \\
\hline $3.3 \times 10^{-4}$ & $\begin{array}{l}1 \\
2\end{array}$ & $\begin{array}{c}0.0004-0.0016 \\
0.002-0.025\end{array}$ & $\begin{array}{r}0.55 \\
-0.52\end{array}$ & $\begin{array}{r}1.0 \times 10^{8} \\
-1.1 \times 10^{5}\end{array}$ & $\begin{array}{l}8.3 \times 10^{6} \\
1.5 \times 10^{7}\end{array}$ \\
\hline $2.6 \times 10^{-5}$ & 2 & $0.0004-0.015$ & -0.23 & $-5.3 \times 10^{5}$ & $8.4 \times 10^{6}$ \\
\hline $3.3 \times 10^{-6}$ & 2 & $0.0004-0.39$ & 0.53 & $5.8 \times 10^{6}$ & $1.1 \times 10^{6}$ \\
\hline
\end{tabular}

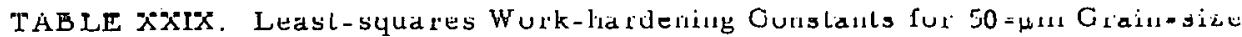
Zircaloy -4 Deformed at $850^{\circ} \mathrm{C}$ and Various Strain Rates

\begin{tabular}{lccrrr}
\hline $\begin{array}{c}\text { Strain } \\
\begin{array}{c}\text { Rate, } \\
\dot{\varepsilon}, \mathrm{s}^{-1}\end{array}\end{array}$ & $\begin{array}{c}\text { Stage } \\
\text { Number }\end{array}$ & $\begin{array}{c}\text { Strain } \\
\text { Interval }\end{array}$ & $\mathrm{n}$ & $\mathrm{k}, \mathrm{Pa}$ & $\begin{array}{c}\text { Average, } \\
\sigma_{0}, \mathrm{~Pa}\end{array}$ \\
\hline $3.3 \times 10^{-2}$ & 1 & $0.0004-0.0028$ & -0.88 & $-5.3 \times 10^{3}$ & $3.8 \times 10^{7}$ \\
& 2 & $0.0032-0.035$ & 1.10 & $1.2 \times 10^{8}$ & $3.8 \times 10^{7}$ \\
$3.3 \times 10^{-3}$ & 1 & $0.0004-0.004$ & 0.89 & $3.0 \times 10^{8}$ & $2.0 \times 10^{7}$ \\
& 2 & $0.004-0.025$ & -0.48 & $-3.0 \times 10^{5}$ & $2.7 \times 10^{7}$ \\
\hline
\end{tabular}

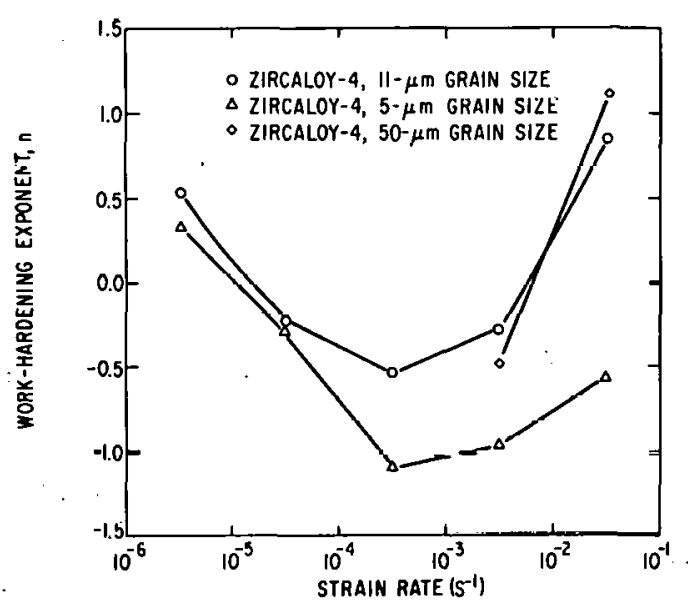

Fig. 130

Strain-rate Dependence of Workhardening Exponent of Zircaloy-4 at $850^{\circ} \mathrm{C}$. ANL Neg. No. 306-77-79 Rev. 2.
'The large effect of hold time on the superplastic ductility demonstrates the importance of phase distribution in Zircaloy. A fine distribution of $\dot{\beta}$ phase both at the $\alpha$-grain boundaries and within the $\alpha$ grains is conducive to superplastic elongations. A continuous thin film of soft $\beta$ phase at the boundaries of the relatively hard $\alpha$ grains appears to be necessary for the maximum superplasticity in Zircaloy. This observation supports the core-mantle model of superplastic deformation proposed by Gifkins. ${ }^{51}$ Longer hold times before deformation result in coalescence of the $\beta$ phase at the $\alpha$-grain boundaries, and the thickness of the $\beta$ film increases with time. Large $\beta$-film thicknesses presumably decrease the efficiency of the "mantle" to assist grain-

boundary sliding at the $\alpha-\beta$ interface. At higher volume fractions of the $\beta$ phase, $\beta$ grains begin to appear in the microstructure, the continuity of the $\beta$ film at the grain boundary is broken, and the $\alpha-\beta$ interface area decreases. These microstructural observations indicate that grain-boundary sliding at the $\alpha-\beta$ interface is important in the superplastic deformation of Zircaloy near $850^{\circ} \mathrm{C}$. 
The $\alpha$-phase morphology provides additional evidence for the importance of grain-boundary sliding on superlasticity of $\mathrm{Zircaloy}$ (Fig. 58). The total elongation of the acicular $\alpha$-grain structure with a large aspect ratio (i.e., transformed $\beta$-phase) is considerably smaller than for the equiaxed $\alpha$ grains. The overall accommodation of grain-boundary sliding is easier in the equiaxed structure than in a structure that contains elongated grains.

The ductility of Zircaloy increases as the grain size of the material decreases, primarily because more grain-boundary area is available for grainboundary sliding in the small-grain-size material. As the grain size decreases from 11 to $5 \mu \mathrm{m}$, the superplastic elongation peak shifts from 850 to $900^{\circ} \mathrm{C}$. In other words, maximum superplasticity is observed in a finer-grain-size material at a higher volume fraction of $\beta$ phase. The higher volume fraction of $\beta$ phase is required to achieve a continuous $\beta$ film at the $\alpha-\alpha$ grain boundaries of the fine-grain material, which has a larger initial $\alpha-\alpha$ grain-boundary area.

Regarding possible mechanisms of superplasticity in Zircaloy, Nabarro ${ }^{52}$-Herring ${ }^{53}$ bulk-diffusion vacancy creep and Coble ${ }^{54}$ grain-boundary vacancy creep are not likely to be directly rate-controlling in Zircaloy, since the strain-rate sensitivity is never close to unity and the grain shape after deformation remains equiaxed.

An experimental determination of the stress and grain-size exponents, $\mathrm{n}$ and $\mathrm{p}$ in $\mathrm{Eq}$. 4, is frequently used to evaluate the relative contributions of different mechanisms of superplastic deformation. Figure 131 is a logarithmic plot of the strain rate versus grain size for stage-II deformation of Zircaloy at $850^{\circ} \mathrm{C}$. The value of $\mathrm{p}$, in Eq. 4, determined from the slope of the curve is -1 .

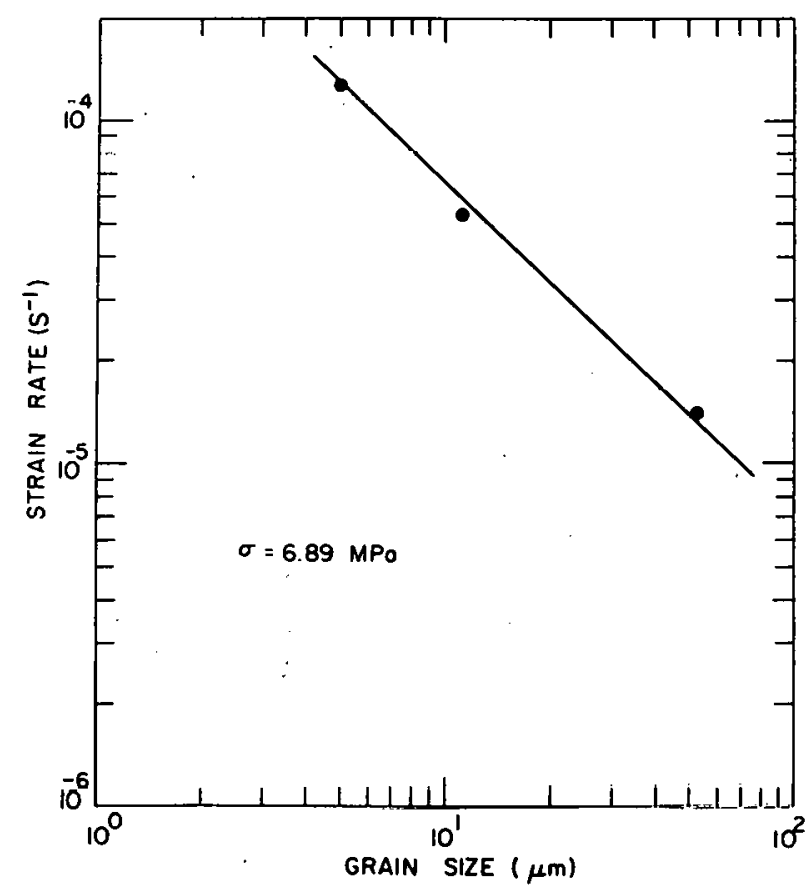

Fig. 131

Logarithmic Plot of Strain Rate as a Function of Grain Size for Stage-II Deformation of Zircaloy-4 at $850^{\circ} \mathrm{C}$. ANL NNeg. No. . 308-78-248 Rev. 1. 
To evaluate the deformation process in the two-phase material at 850 and $900^{\circ} \mathrm{C}$, values of the total strain rate $\dot{\epsilon}_{\mathrm{T}}$ were calculated from the contributions from dislocation creep, in Eq. 4, and from the grain-boundary sliding mechanism with diffusional accommodation, ${ }^{39}$ in Eq. 7 ,

$$
\ddot{\varepsilon}_{\mathrm{D}-\mathrm{A}}=\frac{100 \Omega \mathrm{D}_{\mathrm{V}}}{\mathrm{D}^{2} \mathrm{kT}}\left(\sigma-\frac{0.72 \Gamma}{\mathrm{D}}\right)\left(1+\frac{3.3 \mathrm{WD}_{\mathrm{B}}}{\mathrm{DD}_{\mathrm{V}}}\right) ;
$$

that is,

$$
\dot{\epsilon}_{\mathrm{T}}=\dot{\varepsilon}+\dot{\epsilon}_{\mathrm{D}-\mathrm{A}} .
$$

The definition of the symbols in Eq. 7 and their values are as follows: atomic volume of zirconium $\Omega=2.37 \times 10^{-29} \mathrm{~m}^{3} ;{ }^{54}$ volume diffusion coefficient for zirconium $\ddot{D}_{V}=5.9 \times 10^{-3} \exp \left(-Q_{V} / R T\right) \mathrm{m}^{2} / \mathrm{s}$, where $Q_{\mathrm{V}}-218 \mathrm{~kJ} / \mathrm{molc} ; 43 *$ grain-boundary diffusion coefficient of $\alpha$-zirconium $D_{B}=5.9 x$ $10^{-2} \exp \left(-Q_{\mathrm{B}} / \mathrm{RT}\right) \mathrm{m}^{2} / \mathrm{s}$, where $Q_{\mathrm{B}}=0.60 Q_{\mathrm{V}} ;$ grain size $\mathrm{D}=(5$ or 11$) \times 10^{-6} \mathrm{~m}$; grain-boundary free energy $\Gamma$ is assumed to be zero; and the grain-boundary layer thickness $\mathrm{W}=1 \times 10^{-9} \mathrm{~m}$.

With regard to the additional parameters in Eq. 4, the following values were used for both grain sizes: $n=4.35, p=-1, Q=316 \mathrm{~kJ} / \mathrm{mole}$, and $G=$ $(1.94$ and 1.82$) \times 10^{10} \mathrm{~Pa}$ at 850 and $900^{\circ} \mathrm{C}$, respectively. The constant $\mathrm{A}$ was adjusted so that the computed and measured yield stresses were the same at strain rates $\gtrsim 10^{-3} \mathrm{~s}^{-1}$. (The strain-rate contribution $\dot{\varepsilon}_{\mathrm{D}-\mathrm{A}}$ from Eq. 7 was negligible in this range.) The experimental data and calculated curves for the dependence of yield stress on the strain rate at 850 and $900^{\circ} \mathrm{C}$ are shown in Fig. 132 for the 5- and $11-\mu \pi n$ grail-size materials. The curves, based upon Eqs. 4, 7, and 8 and the values for the parameters listed above, are in good agreement with the experimental data at strain rates $\leqslant 10^{-3} \mathrm{~s}^{-1}$ at which the transition to stage-II behavior occurs.

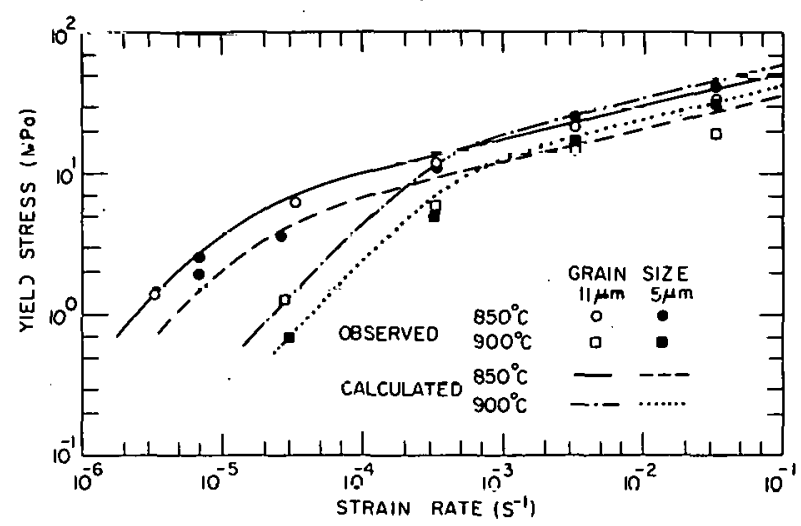

l'ig. 138

Comparison of Calculated and Experimental Strain-rate Dependence of $0.2 \%$ Yield Stress for $5-$ and $11-\mu \mathrm{m}$ Grain-size Zlrcaluy-4 al 850 and $900^{\circ} \mathrm{C}$. ANL Neg. No. 306-76-253 Rev: 1 .

*The diffusion coefficient of zirconium in $\alpha$-zirconium and zirconium-tin alloys is sensitive to the dislocation density in the material. ${ }^{44}$ The lower activation energy for zirconium diffusion, in Ref. 43 , is more appropriate for a material undergoing plastic deformation. 
Although the Ashby-Verrall model ${ }^{39}$ was originally proposed for single-phase material, the information in Fig. 132 and microstructural observations indicate that it is also applicable for two-phase materials. Figure 127 shows that the grains do not elongate during deformation and new grains (free of scratches) appear on the surface following deformation at $\dot{\varepsilon}=3.3 \times 10^{-4} \mathrm{~s}^{-1}$ at $900^{\circ} \mathrm{C}$ (stage II). In addition, a tendency for grain rota tion and grain-boundary sliding is observed. Figure 125 shows a microstructure that is characteristic of stage-III behavior, i.e., elongated grains that result from dislocation activity, for Zircaloy-4 deformed at a strain rate of $3 \times 10^{-1} \mathrm{~s}^{-1}$ at $850^{\circ} \mathrm{C}$. These observations, in addition to the large value of the strain-rate sensitivity for the two-phase material ( $\mathrm{m} \sim 0.8$ at low-strain rates) and the dependence of the strain rate on grain size $(-3<p<0)$ are consistent with the Ashby-Verrall model. The model also predicts the shift in the stress-versus-strain-rate curves, in Fig. 132, to higher strain rates as the temperature increases.

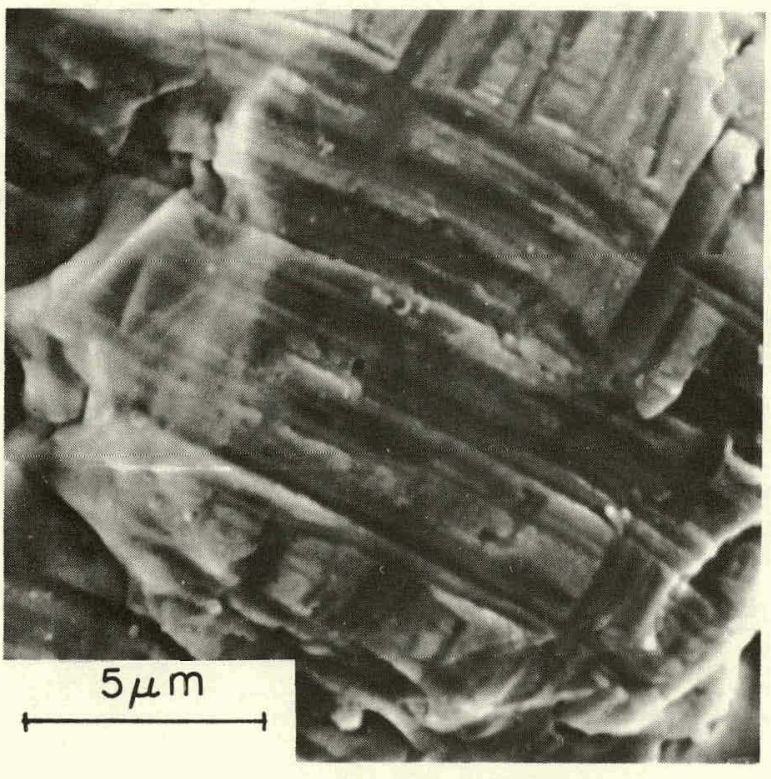

Fig. 133

Slip Lines on Surface of a Zircaloy-4 Specimen Deformed at $850^{\circ} \mathrm{C} ; \dot{\varepsilon}=$ $3.3 \times 10^{-1} \mathrm{~s}^{-1}$. Neg. No. MSD-63846.

To supplement the work concerning the mechanism of superplastic deformation in Zircaloy at $850^{\circ} \mathrm{C}$, sur faces of deformed tensile specimens were examined by scanning-electron microscopy. Figure 133 represents the surface of the thinnest side of a Zircaloy- 4 specimen deformed at $850^{\circ} \mathrm{C}$ at the strain rate of $3.3 \times 10^{-1} \mathrm{~s}^{-1}$. The observed broad slip lines within the grain imply that transgranular deformation due to dislocation slip was important at this fast strain rate, which is within the region of stage-III deformation. Note that the offset at the grain boundary separating two grains is not pronounced; this indicates that grain-boundary sliding is not important in stage-III deformation.

Similar surface microstructure for a specimen deformed at a lower strain rate of $3.3 \times 10^{-6} \mathrm{~s}^{-1}$, in the stage-II region, is shown in Fig. 134. In this case, the step formation at the grain boundary is significant and shows the importance of grain-boundary sliding. The fine crystalline faceting within the grains is due to thermal etching of the surface during the long-test times at high temperature in a vacuum environment. Faceting was also observed on samples held in a similar vacuum at $850^{\circ} \mathrm{C}$ without deformation. Note the multiplicity of the crystalline planes along which thermal etching occurs. Compared to the slip lines in Fig. 133, the steps that formed during thermal etching, in Fig. 134, are 
sharper and finer. The absence of slip lines in Fig. 134 implies that, at this low strain rate, trans granular deformation due to dislocation slip is unimportant. The observed grain-boundary sliding is accommodated by diffusion creep. These observations are consistent with conclusions that, at $850^{\circ} \mathrm{C}$ in stage II, grain-boundary sliding accommodated by diffusion creep is important, and that, in stage III, trans granular deformation due to dislocation motion predominates.

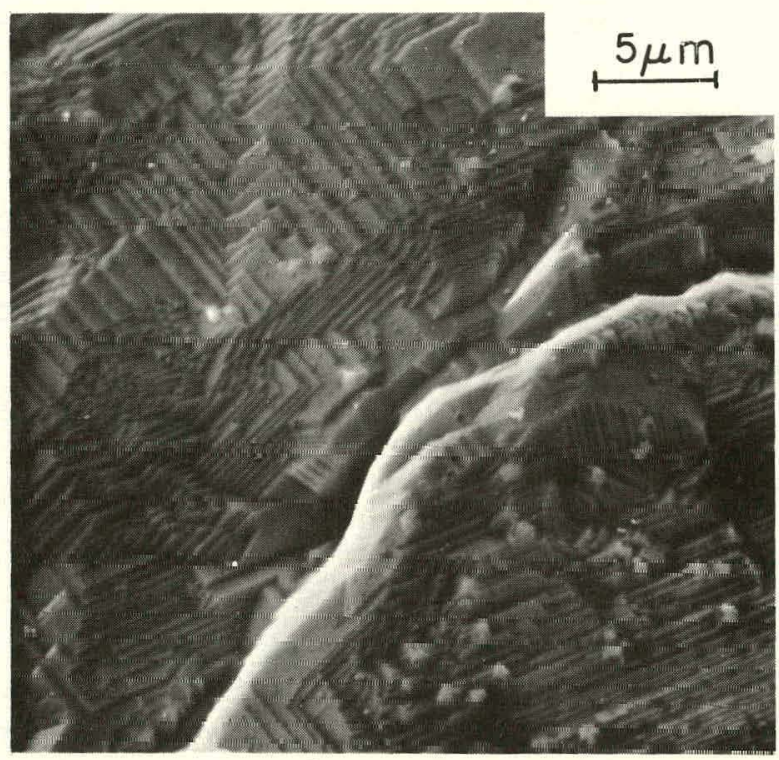

Fig. 134

Facets due to Thermal Etching of Surface of a Zircaloy-4 Specimen Deformed at $850^{\circ} \mathrm{C} ; \dot{\varepsilon}=3.3 \mathrm{x}$ $10^{-6} \mathrm{~s}^{-1}$. Neg. No. MSn-fi3845 


\section{CONCLUSIONS}

The uniaxial tensile behavior of Zircaloy- 2 and -4 and Zircaloy-oxygen alloys was investigated over a wide range of temperatures, strain rates, oxygen concentrations, and microstructural states. The following conclusions can be drawn from the experimental results:

1. Superplastic strain maxima were observed in Zircaloy at 850 , 1000 , and $\sim 1300^{\circ} \mathrm{C}$. Maximum superplastic elongations occurred at $850^{\circ} \mathrm{C}$ in the two-phase region, in which the microstructure consists of a thin film of soft $\beta$ phase at the boundaries of the $\alpha$ grains. The ductility values in excess of several hundred percent are consistent with large values of the strain-ratesensitivity parameter. The dominant mechanism of superplasticity in Zircaloy at $850^{\circ} \mathrm{C}$ is grain-boundary sliding with accommodation by diffusional flow, dislocation slip, and grain-boundary migration.

2. Dynamic strain-aging manifestations such as yield points and high work-hardening rates were observed in Zircaloy near 200 and $700^{\circ} \mathrm{C}$.

in

3. The mechanical properties of Zircaloy are a function of texture below $600^{\circ} \mathrm{C}$. However, at higher temperatures, the properties are independent of texture.

4. The microstructure (and hence the mechanical properties) of transformed $\beta$-phase Zircaloy depends on the cooling rate through the $\alpha+\beta$ region.

5. In a homogeneous Zircaloy-oxygen alloy, an increase in the oxygen concentration increases the ultimate tensile strength and decreases the total strain.

6. Oxygen increases the ultimate tensile strength of Zircaloy-oxide composite specimens. The effect is more pronounced at temperatures above $1000^{\circ} \mathrm{C}$ because the $\alpha$-phase surface layer does not crack.

7. Below $600^{\circ} \mathrm{C}$, where transgranular deformation of $\alpha$ phase is important, the work-hardening exponent shows positive values. In the temperature region of $700-1100^{\circ} \mathrm{C}$, where intergranular deformation is significant, the work-hardening exponent as sumes negative values. Above $1100^{\circ} \mathrm{C}$, the work-hardening exponent is positive.

\section{ACKNOW LEDGMENTS}

This work was sponsored by the U. S. Nuclear Regulatory Commission, Office of Nuclear Regulatory Research. We are grateful to M. L. Picklesimer for helpful discussinns. Experimental assistance of W. K. Soppet, L. J. Marek, and L. P. Burkel is acknowledged. F. J. Karasek fabricated the fine-grainsize Zircaloy-4 sheet material. 


\section{REFERENCES}

1. Light-water-reactor Safety Research Program: Quarterly Progress Report, January-March 1975, Sec. III, "Mechanical Properties of Zircaloy Containing Oxygen," ANL-75-28 (June 13, 1975).

2. Light-water-reactor Safety Research Program: Quarterly Progress Report, Apriz-June 1975, Sec. III, "Mechanical Properties of Zircaloy Containing Oxygen," ANL-75-58 (Sept 26, 1975).

3. Light-water-reactor Safety Research Progrom: Quarterly Progress Report, July-September 1975, Sec. III, "Mechanical Properties of Zircaloy Containing Oxygen," ANL-75-72.

4. Light-water-reactor Safety Research Progrom: Quarterly Progress Report, October-December 1975, Sec. III, "Mechanical Properties of Zircaloy Containing Oxygen," ANL-76-15.

5. Light-hatep-lecicton Safoty Rosenroh Frogram; Qucaterly Prograss Report, January-Mareh 1976, 3è. III, "Mochanisâ! Prnperlies of Zircaloy Containing Oxygen," ANL-76-49.

6. Light-water-reactor Safety Research Program: Quarterly Progress Report, Apri,-June 1976, Sec. III, "Mechanical Properties of Zircaloy Containing Oxygen," ANL-76-87.

7. Light-water-reactor Safety Researuh Program: Quarterly Progress Report, July-September 1976, Sec. III, "Mechanical Properties of Zircaloy Containing Oxygen," ANL-76-121.

8. Light-water-reactor Safety Kesearch Proyran: Quartorly Progress Report, October-December 1976, Sec. III, "Mechanical Properties of Zircaloy Containing Oxygen," ANL-77-10.

9. M. L. Picklesimer, Fuel Behavior Research Branch, Nuclear Regulatory Commission, Washington, D.C., private communication.

10. E. M. Savitskii, M. A. Tylkina, and I. A. Cyganova, Zustandsdiagramm dos Systems Zirkonium-Rhenium, Kernenergie 3, 641 (1960).

11. M. I. Picklesimer, Anodizing for Controlzed Miorostructurat Contrast by Color; The Microscope 15, 472 (196\%).

12. M. I. Picklesimer, Anodizing as a Metallographic Technique for Zirconium Buse AZloyg, ORNL-2.296 (May 195\%).

13. P. ח. Kaufmann, P. Danielson, and E. F. Baroch, Zirconium in Nuclear Applications, ASTM-STP 551, pp. 52-62, Amerleun 3ociety for Toeting and Materials, Phịladelphia, Pa. (1974).

14. C. Crussard and B; Jaoul, Contribution à l'étude de la forme des courbes de traction des métaux et a son interpretation phlysique, Rev. Metall. 47, 589 (1950).

15. C. Crussard, Rapport entre la forme exacte des courbes de traction des métaux et les modifications concomitantes de Zeur structure, Rev. Metall. 50, 697 (1953).

16. B. Jaoul, Etude de Za Forme des Courbes de Deformation PZastique, J. Mech. Phys. Solids 5, 95 (1957). 
17. P. Ludwik, EZemente der Technologischen Mechanik, Julius Springer, Berlin, p. 32 (1909).

18. A. M. Garde and R. E. Reed-Hill, Dual Analysis of Longitudinal and Transverse Zirconium Tensize Stress-Strain Data, ASTM-STP 551, 75-91 (Aug 1974).

19. R. H. Meservey and R. Herze1, Brittle Behavior of Zircaloy in an Emergency Core Cooling Environment, IN-1389 (Sept 1970).

20. W. A. Backofen, D. L. Holt, D. Lee, P. Martin, and F. J. Azzarto, Deformation Processes in Anisotropic Metals, MIT Final Report to Naval Air Systems Command under Contract NOW-66-0068-d (July 1966).

21. A. M. Garde, E. Aigeltinger, B. N. Woodruff, and R. E. Reed-Hill, Concerning the Strength of Dynomic Strain Aging in Zirconizm, Metall. Trans. 6A, 1183-1188 (June 1975).

22. K. Veevers and W. B. Rotsey, Effect of Irradiation on Strain Aging in Annealed Zircaloy-2, J. Nuc1. Mater. 27, 108 (1968).

23. K. Veevers, W. B. Rotsey, and K. U. Snowden, The Effect of Neutron Irradiation and Cold Work on the Strain Aging Behavior of Zircaloy-2, ASTM-STP 458, American Society for Testing and Materials, p. 194 (1970).

24. K. Veevers, Strain Aging in Zirconium AlZoys, J. Nucl. Mater. 55, 109 (1975).

25. P. M. Kelly and P. D. Smith, Strain Aging in Zirconium-Oxygen AlZoys, J. Nuc1. Mater. 46, 23 (1973).

26. D. O. Hobson, M. F. Osborne, and G. W. Parker, Comparison of Rupture Data from Irradiated Fuel Rods and Unirradiated Cladding, Nuc1. Tech. 11, 479 (1971).

27. D. O. Hobson and P. L. Rittenhouse, Deformation and Rupture Behavior of Light-water Reactor Fuel Cladding, ORNL-4727 (Oct 1971).

28. D. G. Hardy, High Temperature Expansion and Rupture Behavior of Zircaloy Tubing, Topical Meeting on Water-reactor Safety, Salt Lake City, Utah, March 26-28, 19.73, G. A. Freund, compiler, pp. 254-273.

29. C. C. Busby and K. B. Marsh, High Temperature Deformation and Burst Characteristics of Recrystallized Zircaloy-4 Tubing, WAPD-TM-900 (Jan 1970).

30. H. M. Chung, A. M. Garde, and T. F. Kassner, Deformation and Rupture Behavior of Zircaloy. Cladding under Simulated Loss-of-coolant Accident Conditions, ASTM-STP 633, American Society for Testing and Materials, pp: 82-97 (1977).

31. E. Tenokhoff, Operable Deformation Systems and Mechanical Behavior of Textured Zircaloy Tubing, Zirconium in Nuclear Applications, ASTM-STP 551, American Society for Testing and Materials, p. 179 (1974).

32. G. Östberg, MetalZographic Study of Isothermal Transformation of Beta Phase in Zircaloy-2, Jernkontorets Ann. 145, 119 (1963).

33. G. Ostberg, Determination of the Composition of the Second Phase in Zircaloy, J. Nucl. Mater. 7, 103 (1962).

34. M. Hansen and K. Anderko, Constitution of Binary AZZoys, McGraw-Hill, New York, pp. 1219, 741, and 573 (1958). 
35. M. J. Luton and J. J. Jonas, Solute Strengthening at High Temperature in Zirconium-tin AZloys, Can. Meta11. Q. 11, 79 (1972).

36. R. H. Chapman, Compiler, Characterization of Zircaloy-4 Tubing Procured for Fuel Cladding Research Programs, ORNL/NUREG/TM-29 (July 1976).

37. M. Bǒcek, Kernforschungszentrum Karlsruhe, Institute für Material und Festkörperforschung, West Germany, private communication (May 1975).

38. R. C. Gifkins, Scr. Meta11. 10, 433 (1976).

39. M. F. Ashby and R. A. Verral1, Diffusional-accommodated Flow and Superplasticity, Acta Meta11. 21, 149 (1973).

40. R. F. S. Hearmon, The Elastic Constants of Anisotropic Materials, Adv. Phys. 5, 323 (1956).

41. E. S. Fisher and C. J. Renken, Single Crystal Elastic Moduli and the $h c p \rightarrow b c c$ Transformation in $T i, \mathrm{Zr}$, and $\mathrm{Hf}$, Phys. Rev. 135, A482 (1964).

42. J. J. Kearns, J. E. McCauley, and F. A. Nichols, Effect of Alpha/Beta Phase Constitution on Superplasticity and Strength of 'Lircaloy-4, J. Nuc1. Mater. 61, 169 (1976).

43. V. S. Lyashenko, V. N. Bykov, and L. V. Pavlinov, A Study of Self-Diffusion in Zirconium and Its Alloys with Tin, Fiz. Metall. Metalloved. 8, 362 (1959), English Translation 8, 40 (1960).

44. G. M. Hood and R. J. Schu1tz, Tracer Diffusion in $\alpha-Z r$, Acta Metall. 22, 459 (1974).

45. M. C. Naik and R. P. Agarwala, Self-and Impurity Diffusion in AlphaZirconium, Acta Meta11. 15, 1521 (1971).

46. A. T. Santhanam and R. E. Reed-Hill, Metall. Trans. 2, 2619 (1971).

47. D. Lee and.W. A. Backofen, Trans. AIME 239, 1034 (1967).

48. K, Nutta1.1, Scr. Metall. 10, 835 (1976).

49. G. W. Greenwood and R. H. Johnson, Proc. Roy. Soc. $283 A, 403$ (1955).

50. D. L. Holt and W. A. Backofen, Trans. ASM 59, 755 (1966).

51. R. C. Gifkins, Grain-boundary Sliding and Its Accomodation u'uriry Cleep and Superplasticity, Metall. Trans. 7A, 1225 (1976).

52. F. R. N. Nabarro, "Deformation of Crystals by the Motion of Slugle Iuis," Proc. Conf. on Strength of Solids, Phys. Soc. of London, Cambrldge, p. 75 (1948).

53. C. Herring, Diffusional Viscosity of a Polycrystalline Solid, J. App1. Phys. 21, 437 (1950).

54. R. L. Coble, A Model for Boundary Diffusion Controlled Creep In Pulycrystalline Materials, J. App1. Phys. 34, 1679 (1963).

55. L. T. Lloyd, Thermal Expaneion of Alpha-Zirconium Single Crystals, ANL-6591 (Jan 1963). 